\title{
Going Above and Beyond: Dependence and Military Coalition Participation
}

\author{
Min-Gyu PAIK \\ Charlottesville, Virginia
}

Bachelor of Arts, Republic of Korea Air Force Academy, 2001

Master of Arts, University of Virginia, 2015

A dissertation presented to the Graduate Faculty of the

University of Virginia in candidacy for the Degree of

Doctor of Philosophy

The Woodrow Wilson Department of Politics

University of Virginia

May, 2016 
"War can really cause no economic boom, at least not directly, since an increase in wealth never does result from destruction of goods."

"The essence of so-called war prosperity; it enriches some by what it takes from others. It is not rising wealth but a shifting of wealth and income."

Ludwig von Mises 
$I$.

It was six men of Indostan

To learning much inclined, Who went to see the Elephant (Though all of them were blind),

That each by observation

Might satisfy his mind.

II.

The First approached the Elephant, And happening to fall

Against his broad and sturdy side,

At once began to bawl:

"God bless me! but the Elephant Is very like a wall!"

\section{III.}

The Second, feeling the tusk,

Cried, "Ho! what have we here

So very round and smooth and sharp?

To me't is mighty clear

This wonder of an Elephant

Is very like a spear!"

IV.

The Third approached the animal,

And happening to take

The squirming trunk within his hands,

Thus boldly up and spake:

"I see," quoth he," the Elephant

Is very like a snake!"
$V$.

The Fourth reached out his eager hand, And felt about the knee.

"What most this wondrous beast is like

Is mighty plain," quoth he;

"'T is clear enough the Elephant Is very like a tree!"

VI.

The Fifth, who chanced to touch the ear,

Said: "E'en the blindest man

Can tell what this resembles most;

Deny the fact who can,

This marvel of an Elephant Is very like a fan!"

VII.

The Sixth no sooner had begun

About the beast to grope,

Than, seizing on the swinging tail

That fell within his scope,

"I see," quoth he, "the Elephant is very like a rope!"

VIII.

And so these men of Indostan

Disputed loud and long,

Each in his own opinion

Exceeding stiff and strong,

Through each was partly in the right, And all were in the wrong! 


\section{Abstract}

Why do states contribute to the military endeavors of another, that are seemingly distant from their central security interests? I argue that states do so due to their economic and/or security related dependence on the state leading such an effort. The argument is presented as an alternative, and more comprehensive, theory of military coalition participation that is overlooked by conventional theories in the alliance and war diffusion literatures. Logit analyses of three competing arguments (dependence, balance of threat, and opportunity/willingness) support the dependence argument most consistently, and the proposed mechanisms are illustrated through two case studies. Additionally, I argue that the politics of inattention in asymmetric dyads lead to outcomes that may not follow the expectations of states. While states participate in coalitions with the hopes of being rewarded in some manner, additional analyses regarding the amount of rewards states receive for their participation demonstrate that such rewards are temporary. 1

국가들은 왜 자국의 안보와 무관한 타국의 군사활동에 동참하는가? 이 논문은 이러 한 현상이 해당 군사활동을 주도하는 타국에 대한 경제/안보 관련 의존도와 관련이 있다고 주장한다. 이는 현존하는 군사동맹 및 전쟁확산 이론들과는 달리, 연합군 참 여에 대한 보다 포괄적이고 깊이있는 이해를 가능케 한다. 2차 세계대전 이후 미국이 주도한 6개의 전쟁에 참가한 국가들을 대상으로 로짓분석(Logit Analysis)을 실시한 결과, 본 논문이 주장하는 의존이론(Dependence Theory)이 위협균형(Balance of Threat) 이론이나 전쟁확산 (War Diffusion) 이론보다 연합군 참여를 잘 설명하며 그 예상과 결과에 있어 더 일관성이 있다. 통계적 분석에 추가하여 두 개의 사례를 통해 해당 이론의 원리(mechanism)도 예증한다. 본 논문은 또한 두 국가 사이의 불 균형에서 초래되는 후원국가(patron)의 무관심이 연합군 참여 이후의 결과에 영향을 미친다고 주장한다. 혜택국가(protégé)들은 연합군 참여에 따른 보상을 바라며 참여 하지만, 후원국가의 무관심은 이러한 기대에 부응하지 못하는 결과를 가져온다: 즉, 국가들은 연합군에 참가할 때 보상을 바라지만, 그러한 보상은 일시적일 뿐이다.

\footnotetext{
${ }^{1}$ Disclaimer: The views expressed in this dissertation are those of the author and do not reflect the official policy or position of the Republic of Korea Air Force, the Ministry of National Defense, or the Korean Government.
} 


\section{Acknowledgements}

This dissertation would not have been made possible without the generous support of various people. First of all, I would like to thank the Republic of Korea Air Force, and all of the people involved, for making this possible. My past four years of graduate study were made possible with a generous grant from the organization, for which I am most grateful, and I hope to be able to payback the debt with what I have learned here throughout my career. Within the Korean Air Force, I would especially like to express my gratitude to General Cho DG, who encouraged me to apply when the opportunity to study arose, and to all of those within the associated branch in charge of education abroad, who helped me stay focused on academic issues by taking care of all other administrative and financial issues. I would also like to express my gratitude to $\mathrm{Lt}$ General Stephen G. Wood, USAF (Ret), whom I met while he served as the 7th AF Commander in Korea. While I only served him briefly, I learned a great deal from his enthusiastic and professional attitude.

On the academic side, I first and foremost thank the members of my wonderful committee: Todd Sechser, Jon Kropko, Dale Copeland, and Albert Choi. No one could ask for a better group of academical advisors, and I thank each and every one of them for their endless moral and academic support. All of the members never hesitated to find time to read and discuss my work, making crucial suggestions and providing constructive feedback. The faculty and my colleagues of the politics department at the University of Virginia have also contributed to this work and my professional development through various classes, seminars, workshops, and discussions. I hope I am forgiven for not mentioning each and every one personally.

Finally, I would like to express my deepest gratitude to my wife Nina, and my two great boys, Seung-Hyun "Paik," and Joo-Hyun "JooJoo." This moment would not have come to be without the patience of my family and the sacrifices they made. Deciding to tackle graduate studies at a comparatively late time in 
life, I spent countless late nights studying and found a new irritable side of my personality, and Nina put up with it all, all while adjusting to a new country and culture while taking care of two wonderful boys full of energy and life.

The following work is not perfect, as is the case with all human creation. However, if any good is to come from it, it is needless to say that all glory belongs to the Lord, while any and all shortcomings and mistakes are mine alone. 
이 논문은 여러사람의 도움 없이는 불가능 했을 것입니다. 우선, 대학원 생활을 가능하게 해준 대한민국 공군과 관련 인사들에게 감사드리고자 합니다. 지난 4 년간 의 연구생활은 해당 기관의 아낌없는 물적/심리적 후원 없이는 불가능 했을 것이며, 특히, 교육의 기회가 왔을때 적극적으로 독려해주신 조덕구 장군님, 그리고 교육과 정 중 학업에만 제가 몰두할 수 있게 도와주신 인적자원개발 관련 모든 이들에게 감사를 드립니다. 추가하여 한국 공군은 아니지만, 미 7공군 사령관으로 재직하였던 Stephen Wood 장군에게도 감사드립니다. 비록 짧은 기간이지만, 함께 근무하면서 그분의 전문적이고 열정적인 근무자세에서 많은 것을 배웠습니다. 이외에도 가까운 동료 장교들의 지속적인 관심과 독려 없이는 현재의 제가 있을 수 없었을 것입니다.

학술적 측면에서는 우선 제 논문 위원장을 맡아주신 Todd Sechser 교수 및 위원 회에 소속된 Dale Copeland, Jon Kropko, 및 Albert Choi 교수들에게 감사의 말을 남깁니다. 이들은 모두 끊임없이 연구주제에 대한 관심을 보여주었으며, 초기 간단한 아이디어에 불과하였던 주제가 현재 논문의 모습을 갖출 수 있도록 지속적인 조언을 해주었습니다. 이외에도 버지니아 대학교 정치학과 내 여러 교수진 및 동료 대학원생 들도 수업, 대화, 및 학회를 통하여 여러 방면으로 도움을 주었으며, 이 글을 통하여 일일이 호명하고 감사를 표현하지 못함을 양해하여 주기 바랍니다.

마지막으로, 아내 유니나 및 두 아들 승현, 주현에게 깊은 감사의 말을 남깁니다. 가족의 많은 희생과 인내 없이는 지금 이 순간이 불가능 했을 것입니다. 늦은 시기에 공부한다고 겁없이 달려든 남편의 잦은 밤샘 공부와 날카로워진 성질을 다 받아주고 낮선 땅에서 두 아들 및 남편 뒷바라지해준 고마운 아내는 논문이 마무리에 들어간 이 시점의 일등공신입니다.

부족한 작품이지만, 혹여라도 이 논문이 세상 및 학계에 일말의 이바지를 한다면 모든 영광은 하나님의 것임을 고백하며, 모든 부족한 사항과 실수는 저의 부족함으로 인한 것임을 밝히는 바입니다. 


\section{Contents}

\begin{tabular}{lll}
\hline Abstract & iii
\end{tabular}

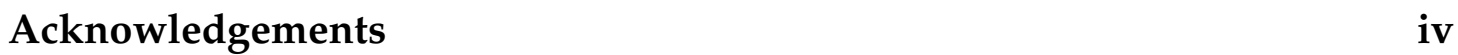

Contents vii

\begin{tabular}{|c|c|c|}
\hline List of Figures & $x$ \\
\hline
\end{tabular}

List of Tables

\begin{tabular}{|ll}
\hline Abbreviations & xiii
\end{tabular}

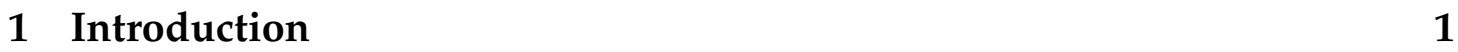

1.1 Introduction: Going Above and Beyond . . . . . . . . . . . . . . 2

1.2 Why Military Coalition Participation? . . . . . . . . . . . . . . . . 4

1.3 Dependence as the Cause of IMC Participation . . . . . . . . . . 6

1.4 Coalitions and Alliances . . . . . . . . . . . . . . . . . 9

1.5 Conclusion: Plan and Overview of the Project. . . . . . . . . . . . 18

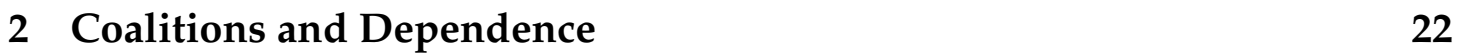

2.1 International Military Coalitions . . . . . . . . . . . . . . . 23

2.2 Balance of Threat and War Diffusion as Possible Explanations of

IMC Participation . . . . . . . . . . . . 30

2.2.1 Alliance Formation as a form of Balancing Threats . . . . . 31

2.2.2 Willingness, Opportunity, and the Diffusion of War . . . . 33

2.2.3 Towards Synthesis: Alliance Dependence, Economic Linkage, and Changing Focus $\ldots \ldots \ldots \ldots 37$

2.3 Dependence and Coalition Participation . . . . . . . . . . . . . . 42

2.3 .1 Dependence . . . . . . . . . . . . . . . . 42

2.3.2 Dependence as the Cause of IMC Participation . . . . . . . 44 
2.3.3 Rewards, Reputations, and the Shadow of the Future . . . 52

2.3.4 Means and Ends: Dependence Types and Modes . . . . . . 53

2.4 A Game of IMC Participation and Rewards . . . . . . . . . . . . . . . . . 57

2.4 .1 The Costs of War . . . . . . . . . . . . . . . . . . . . . . . . . 67

2.4 .2 Payoffs . . . . . . . . . . . . . . . 60

2.4 .3 The Game in Extensive Form . . . . . . . . . . . . . . . . . 61

2.4.3.1 No Exit Cost Game . . . . . . . . . . . . 62

2.4 .3 .2 Exit Cost Game . . . . . . . . . . . . . . . . . . . . . . . 64

2.5 Hierarchy and Dependence . . . . . . . . . . . . . . . . . . . 66

2.6 Conclusion . . . . . . . . . . . . . . . 67

3 Following the US into War: Participation in US-led IMCs post $1945 \quad 70$

3.1 Dependence and IMC Participation . . . . . . . . . . . . . . . 71

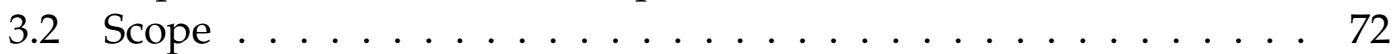

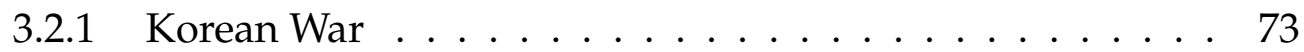

3.2 .2 Vietnam $W a r \ldots \ldots \ldots 73$

3.2 .3 Gulf War . . . . . . . . . . . . . . . . . . . . . . . . . 74

3.2 .4 Kosovo Air Campaign . . . . . . . . . . . . . . . . . . . . . . . . . . . . . . . . . .

3.2 .5 Afghanistan . . . . . . . . . . . . . . . . . . . . . . . . . . 75

3.2 .6 Iraq War $\ldots \ldots \ldots \ldots \ldots \ldots$

3.3 Research Design . . . . . . . . . . . . . . . . . . . . . 76

$3.3 .1 \quad$ Dependence and IMC Participation . . . . . . . . . . . 80

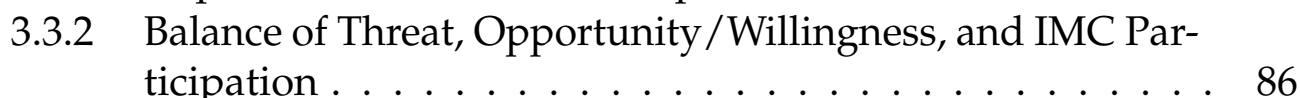

3.4 Methodology. . . . . . . . . . . . . . . . . . . . . . . . . . . . 91

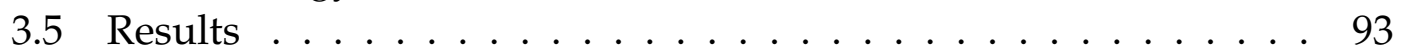

3.6 Discussion . . . . . . . . . . . . . . . . . . . . . . . 97

3.7 Conclusion . . . . . . . . . . . . . . . . . . . . 101

4 Following the US to Vietnam and Korea: Case Studies of South Korea $\begin{array}{ll}\text { and Brazil } & 103\end{array}$

4.1 Introduction . . . . . . . . . . . . . . . . . . . . . . 104

4.2 Korea: Economic Expectations and Security Fears . . . . . . . . . 106

4.3 Brazil: Economic Expectations and Domestic Restraint. . . . . . . 116

4.4 Conclusion . . . . . . . . . . . . . . . . 122

5 After Following the US into War: Are States Right to Do So? 125

5.1 Introduction: Expectations and Outcomes . . . . . . . . . . . . . 126

5.2 Rewards and the Politics of Inattention . . . . . . . . . . . . . . . 127

5.3 Korea in the Vietnam War: A Benchmark Case for the Rewards for Participation Argument . . . . . . . . . . . . . . . . . 131

5.4 Assessing the Impact of IMC Participation on Aid . . . . . . . . 135 
5.4 .1 Scope . . . . . . . . . . . . . . . . . . 135

5.4 .2 Research Design . . . . . . . . . . . . . . . . . . . . . . . . . . . . . . . . . . . . .

5.4 .3 Methodology . . . . . . . . . . . . . . . . . . . . . . . . . . . . . . . . . . . . . . . . . . .

5.4 .4 Results . . . . . . . . . . . . . . . . . . . . 140

5.4 .5 Discussion . . . . . . . . . . . . . . . . . 141

5.5 Conclusion . . . . . . . . . . . . . . . . . . . 142

$\begin{array}{lll}6 & \text { Conclusion } & 143\end{array}$

6.1 Dependence, IMC Participation, and its Consequences . . . . . . 144

6.2 Implications and Areas for Future Research . . . . . . . . . . . . 146

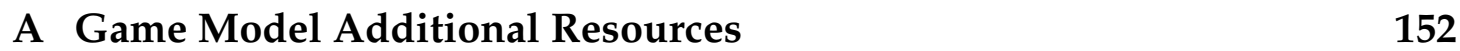

A.1 Parameters . . . . . . . . . . . . . . . . . . 153

A.2 Extensive Form Game with Payoffs . . . . . . . . . . . . . . . . . 154

A.3 Mathematical Proof of Ordering the Payoffs . . . . . . . . . . . . . 155

A.3.1 Payoffs for a Patron with exit costs . . . . . . . . . . . . . . . . . . . 155

A.3.2 $\quad$ Payoffs for a Patron without exit costs . . . . . . . . . . . 156

A.3.3 Payoffs for a Protégé who poses exit costs for its patron. . 159

A.3.4 Payoffs for a Protégé who can not pose exit costs . . . . . . 160

A.4 The Game with Reversed Sequence . . . . . . . . . . . . . . . . 162

\begin{tabular}{|l|l}
\hline B Additional Tables and Figures & 164
\end{tabular}

C Full Translated Text of President Park's Speeches 186

C.1 Statement to the Nation: January 26, 1965 . . . . . . . . . . . . . . 187

C.2 Send Off Speech: October 12,1965 . . . . . . . . . . . . . . . . . . 189

\begin{tabular}{lr}
\hline Bibliography & 193
\end{tabular} 


\section{List of Figures}

$1.1 \quad$ Alliances and Coalitions $\ldots \ldots \ldots \ldots \ldots$

$2.1 \quad$ Balance of Threat and IMC Participation . . . . . . . . . . . . . 34

2.2 Opportunity, Willingness, and IMC Participation . . . . . . . . . . 38

2.3 Decision Model of Coalition Participation Based on Dependence. 51

2.4 Notation $\ldots \ldots \ldots \ldots \ldots \ldots \ldots \ldots$

2.5 Preferences . . . . . . . . . . . . . . . . . . . 62

2.6 Participation and Rewards Game: No Exit Costs . . . . . . . . . 63

2.7 Participation and Rewards Game: With Exit Costs . . . . . . . . 65

$3.1 \quad$ Trade: Predictive Margins with $95 \%$ Confidence Intervals . . . . . . . 98

3.2 Defense Alliance Commitments: Predictive Margins with 95\% Confidence Intervals $\ldots \ldots \ldots \ldots$. . . . . . . . . . . . . . . . . . . . . . 99

3.3 US Troops: Predictive Margins with $95 \%$ Confidence Intervals $\ldots . .100$

$4.1 \quad$ Korea: 1953-1963 aid from, and trade with, the US . . . . . . . . . . . 110

4.2 Korean Dependence and Vietnam Participation . . . . . . . . . . 115

5.1 Expectations of States . . . . . . . . . . . . . . . . . . . 127

5.2 US Aid to Korea : 1960-1968 . . . . . . . . . . . . . . . . . . . 133

5.3 US Aid to Korea : 1960-1980 . . . . . . . . . . . . . . . . . . . . . . 134

$5.4 \quad$ Military Aid to Participant Countries . . . . . . . . . . . . . . 135

5.5 Change in Military Aid to Participants . . . . . . . . . . . . 141

A.1 Parameters . . . . . . . . . . . . . . . . . . . . . . . . 153

A.2 Participation and Rewards Game: No Exit Costs . . . . . . . . . 154

A.3 Participation and Rewards Game: With Exit Costs . . . . . . . . . 154

A.4 Participation and Rewards Game: No Exit Costs(reversed) . . . . 163

A.5 Participation and Rewards Game: With Exit Costs(reversed) . . . 163

B.1 Trade: Distribution of States at each start year of events . . . . . . . . 173

B.2 Changes in Military Aid During Vietnam percentage change from 1965176

B.3 Military Aid to Participant Countries . . . . . . . . . . . . . . 180

B.4 Military Aid to Non-Participant Countries 1 of 10 . . . . . . . . 180 
B.5 Military Aid to Non-Participant Countries 2 of 10 . . . . . . . . . . 181

B.6 $\quad$ Military Aid to Non-Participant Countries 3 of 10 . . . . . . . . . . 181

B.7 $\quad$ Military Aid to Non-Participant Countries 4 of 10 . . . . . . . . . . 182

B.8 Military Aid to Non-Participant Countries 5 of 10 . . . . . . . . . . 182

B.9 Military Aid to Non-Participant Countries 6 of 10 . . . . . . . . . . 183

B.10 Military Aid to Non-Participant Countries 7 of 10 . . . . . . . . . . 183

B.11 Military Aid to Non-Participant Countries 8 of 10 . . . . . . . . . . 184

B.12 Military Aid to Non-Participant Countries 9 of 10 . . . . . . . . . . 184

B.13 Military Aid to Non-Participant Countries 10 of 10 . . . . . . . . . 185 


\section{List of Tables}

2.1 Patron Costs of War . . . . . . . . . . . . . . . . . . 61

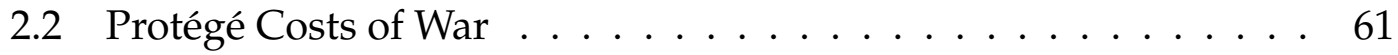

2.3 Dependence, Balance of Threat, and O/W . . . . . . . . . . . . 69

3.1 Military Coalitions and Participants(1) . . . . . . . . . . . . . . . 81

3.2 Military Coalitions and Participants(2) . . . . . . . . . . . . . . . . . . 82

3.3 Summary Statistics: all cases(IVs) . . . . . . . . . . . . . . . . . 85

3.4 Summary Statistics: all cases(BoT and O/W) . . . . . . . . . . . . . . . . . . . . . 99

3.5 Summary Statistics: Power of Target . . . . . . . . . . . . . . . . . 90

3.6 Logit Results: Odds Ratios . . . . . . . . . . . . . . . . . . . . . . . 94

3.7 Balance of Threat and $\mathrm{O} / \mathrm{W}:$ Assessment $\ldots \ldots$. . . . . . . . . 96

3.8 Dependence Models: Marginal Effects . . . . . . . . . . . . . . . . . . . . . . 97

3.9 Summary of Support for Arguments . . . . . . . . . . . . . . . . 102

5.1 OLS: Results . . . . . . . . . . . . . . . . . . . . . . . . . . 140

B.1 Sources for Coding(1) . . . . . . . . . . . . . . . . . . . 166

B.2 Sources for Coding(2) . . . . . . . . . . . . . . . . . . . . . . . . . . . . . . . . . . . . . . .

B.3 Logit Results: Odds Ratios . . . . . . . . . . . . . . . . . . . . . . . 168

B.4 Logit Results: Coefficients . . . . . . . . . . . . . . . . . . . . . . . . . . . . . . . . . . . . . . . . .

B.5 Marginal Effects: BoT and $\mathrm{O} / \mathrm{W}$. . . . . . . . . . . . . . . . . . . . 170

B.6 Logit with CoW DV Results: Odds Ratios . . . . . . . . . . . . . . 171

B.7 $\quad$ Logit with only Start Years: Odds Ratios . . . . . . . . . . . . . . . 172

B.8 Trade(logged): Predictive Margins of Participation . . . . . . . . . 174

B.9 Troops: Predictive Margins of Participation . . . . . . . . . . . . . 175

B.10 Reference Points for Changes in Aid . . . . . . . . . . . . . . . . . 175

B.11 Full OLS Results . . . . . . . . . . . . . . . . . . . . . . . . . 177

B.12 Alternate OLS(a) : immediate effect in Vietnam set to 1969 to account for

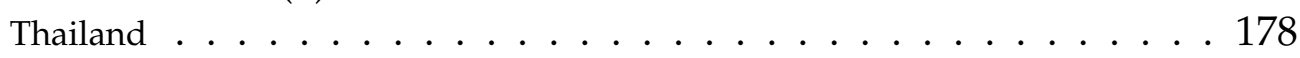

B.13 Alternate OLS(b) : Kosovo not included . . . . . . . . . . . . . 179 


\section{Abbreviations}

CENTCOM CENTral Command(, United States)

CI Confidence Interval

CINC Composite Index of National Capability

COTW Coalition Of The Willing

CoW Correlates of War (Project)

DIOR Directorate for Information Operations and Reports

DoD Department of Defense

DV Dependent Variable

FDI Foreign Direct Investment

FROTUS Foreign Relations Of The United States

IMC International Military Coalition

IR International Relations

ISAF International Security Assistance Force

IV Independent Variable

MID Militarized Inter-state Dispute

NATO North Atlantic Treaty Organization

NMC National Material Capabilities

OEF Operation Enduring Freedom

OIF Operation Iraqi Freedom

ROK Republic Of Korea

SE Standard Error

SIAD Statistical Information Analysis Division 


$\begin{array}{ll}\text { SPE } & \text { Subgame Perfect Equilibrium } \\ \text { UAE } & \text { United Arab Emirates } \\ \text { UK } & \text { United Kingdom } \\ \text { UN } & \text { United Nations } \\ \text { UNC } & \text { United Nations Command } \\ \text { US } & \text { United States (of America) } \\ \text { USAID } & \text { United States Agency (for) International Development }\end{array}$


for Nina, Seung-Hyun, and Joo-Hyun.

You are my true wings.

나의 진정한 날개인 니나, 승현, 주현에게 


\section{Chapter 1}

\section{Introduction}

The main purpose of this introductory chapter is to present the research question: Why do states participate in military coalitions abroad that are seemingly irrelevant to, or far from, their main security interests? It then emphasizes the importance of the question for both IR theory and foreign policy, and provides a summary of the main argument. The latter portion discusses the difference between military coalitions and alliances, and provides a preview of the project. 


\subsection{Introduction: Going Above and Beyond}

In response to the break out of the Korean War in 1950, the US led a coalition of United Nations member states' military forces into the conflict. Not only did large states such as the US, United Kingdom, and France participate in this coalition, but much smaller states such as Ethiopia, Turkey, and Colombia also contributed combatants and resources to the joint military endeavor. In total, the military coalition consisted of thirteen states from across the globe. Each of the participating states were of various sizes, came from different continents, had differing levels of capabilities, and their contributions varied widely. For example, while the United Kingdom sent a total of fifty six thousand troops to fight in the war, Ethiopia sent about three and a half thousand.

The number of troops sent by smaller states may seem miniscule in comparison to those made by major powers, yet, their contributions were no mere token forces. The absolute number of troops that such states sent to the war may appear to be small and modest: three and a half thousand seems quite small in comparison to fifty six thousand. However, they are actually quite significant when compared to the sizes and capabilities of such states. To continue the example of the United Kingdom and Ethiopia, a look at the relative sizes of their respective militaries demonstrate the level of commitment Ethiopia showed to the effort. At the time of the Korean War, the United Kingdom had a standing military of some six hundred and eighty nine thousand personnel, and Ethiopia's military personnel was only twenty thousand. This means that the UK sent approximately eight percent of their annual military personnel to the war, wheras Ethiopia sent about seventeen percent.

Just twelve years after the end of the Korean War, the US once again found itself leading another military coalition of international forces, this time, in 
Vietnam. Responding to this coalition effort in 1965 and 1966, the Republic of Korea (South Korea) sent two infantry divisions and additional support units to serve alongside US soldiers..$^{1}$

The country's participation came at a time when it was still recovering from a devastating war that had ended only twelve years earlier. Moreover, it was still facing a grave threat to its security from its immediate northern neighbor. Under the circumstances, one may think that South Korea would have only sent a minimal number of troops to fight in Vietnam. On the contrary, the state's contributions proved to be more than just a token of good will. South Korea's military was the second largest foreign army fighting in Vietnam behind the United States. Their infantry divisions continued to fight in the region until 1973, and, at one point, the Korean forces actually out-numbered American ground forces $\sqrt{2}^{2}$ During the entirety of the conflict, South Korea deployed a total of over three hundred thousand soldiers to serve in Vietnam from 1964 to 1975.3 Considering the fact that their total annual military personnel stood at a little over six hundred thousand at that time should put Korea's intense commitment to the conflict in perspective $4^{4}$

What compelled such disparate states as the United Kingdom and Ethiopia to participate in the Korean War in 1950? What about states like Colombia? The war was geographically on the other side of the globe, apparently not posing any immediate security risks, and did not have the potential of diffusion to its borders in South America. On a similar note, why did South Korea make such a massive commitment to the war in Vietnam? This commitment came at a time

\footnotetext{
${ }^{1}$ Sarantakes, 1999 , p. 42.

2 Ibid. p. 440.

${ }^{3}$ Park, 2003, p. 379.

${ }^{4}$ Mean value for military personnel during the years $1964-1975$ is 620,000 . From the Correlates of War National Material Capabilities data.
} 
when it could have maximized its defense efforts against the immediate threat to its north.

This project aims to address such questions and provide answers. The questions are compelling because conventional theories of war initiation and diffusion do not apply to these states that 'join in' on the primary war effort of another. Furthermore, for states such as Colombia and Ethiopia in the Korean War, and for South Korea in Vietnam, the stakes appear to be far from their central security interests.

Neither does the concept of alliances, which have been proven to have a significant impact on war diffusion, directly address this issue. States seldom sign long standing offensive alliance agreements, and none of the aforementioned states had a formal agreement with the US to come to its aid if the US was to embark on a military campaign that was not for purely defensive purposes.

Shortly put, these states went out of their way to participate in a military coalition that was not central to their security interests. In some cases, they proceeded to do so despite being on the opposite side of the globe of a conflict. In other words, it could be said that these states went 'above and beyond' the terms of their alliance agreements with the US (if they had one) to aid in its military endeavors.

\subsection{Why Military Coalition Participation?}

Motivated by such theoretical and empirical observations, the primary purpose of this study is to propose and test the motivation for states participating in international military coalitions. For the purposes of this project, International Military Coalition(IMC)s are defined as military forces composed of military and/or civilian support personnel from two or more nations that are currently participating 
in an interstate war, or are deployed with the anticipation of participating in such an event within a reasonable timeframe, within which those forces are deployed primarily for combat or combat related activities that have a high likelihood of being exposed to combat and becoming the subject of fatalities. Understanding why states participate in IMCs is not only important for IR theory, but also has significant foreign policy implications.

Of the sixty-four wars that started after 1900, twenty-seven of them had three or more participants, and eleven of them had five or more. This means that an International Military Coalition existed in thirty-eight out of sixty-four wars that started in or after the twentieth century ${ }^{5}$ As for the scale of the conflicts in the same period, thirty-three of the sixty-four had more than five thousand casualties annually, and in sixteen of those cases, there was an IMC involved on either, or both sides ${ }^{6}$

The prevalence of IMCs make it evident that many states do not go to war as a principal agent (i.e., as the target or aggressor; the initial belligerents), but join the war in aid of, or to fight on the side of, another state. However, the security literature has been primarily focused on the causes of war, that it has generally ignored this other important side of the story. The closest area of research may be that of alliances and war diffusion. Yet, even those research programs are more often than not approached from the point of view of major powers: those of the alliance building states. This study shifts the focus onto states that are not the primary actors making decisions to 'go to war,' per se, but that make decisions to participate in others' wars.7

\footnotetext{
${ }^{5}$ Based on CoW, Inter-State War Data

${ }^{6}$ Annual casualties measured by dividing total battle deaths by the number of years of a conflict. Total battle deaths from CoW, Inter-State War Data.

${ }^{7}$ Siverson and Starr, 1990, p. 47.
} 
From a foreign policy standpoint, the US has notably been having difficulty building military coalitions in its recent war efforts. In 2003, the US government released an initial list of states participating in the 'Coalition of the Willing,' that consisted of forty-nine countries across the globe. ${ }^{8}$ However, in reality, only four states (including the US) participated with actual combat forces in the initial attack on Iraq.9

The answers to the questions this study asks should help explain why the US is having such a difficult time building military coalitions recently. In comparison to the thirteen state coalition that participated in the Korean War, only five contributed major combat participants to the initial combat stages of the recent Afghanistan War of 2001, and only three did so in 2003, Iraq.

While this study focuses on coalitions, it should be made clear that I am agnostic as to the reasons why the US builds, or feels the need for, IMCs in the first place. In other words, the factors that lead to the adoption of multilateralism is not the focus of this study. It is only concerned with why states decide to participate in IMCs once such a coalition is present, or impending. ${ }^{10}$ Whatever the reasons for the US' focus on multilateralism, as long as that is its major method of waging war, it is evident that it is becoming more difficult for the US to build a sizable force.

\subsection{Dependence as the Cause of IMC Participation}

International Military Coalition(IMC)s are largely neglected in the IR security literature. This is mainly due to our failure to identify IMCs as being distinct from alliances. The dearth of serious interest has led many to confuse and conflate

\footnotetext{
${ }^{8}$ Carney, 2011, p. 5.

9 Ibid. pp. 5-6.

${ }^{10}$ See Tago, 2005 Corbetta and Dixon, 2004 for studies on the determinants of multilateralism.
} 
IMCs with the well established concept of alliances. However, as discussed above, we are in crucial need of understanding what propels states to participate in IMCs, as opposed to what causes the formation of alliances.

The main argument proposed in this study is that a state's dependence on another state leads it to participate in military endeavors led by the latter. The point is elaborated through two hypothetical states: $X$ and $Y . X$ 's dependence on state $Y$ leads it to participate in an IMC led by $Y$. More specifically, $X$ participates in $Y^{\prime}$ s IMC because it expects such behavior to result in benefits from $Y$ to continue, or increase relative to non-participants, in the future. For the purposes of this study, I term a state that is dependent on another as a protégé (state $X$ ), and one that provides such benefits, making another state dependent on itself, a patron(state $Y$ ).

The notion of dependence, or interdependence, is not a new idea or concept in IR and foreign policy ${ }^{11}$ However, it has often been confined to the economic realm, and in the few instances it has been related to security, it more often than not depicts the security outcomes of economic dependence, rather than acknowledge the fact that states can be dependent on another for its security as well. 12

Dependence can be economic and/or security related, and manifest itself in several forms. This is a departure from other related works that have focused on alliances or economic linkage as the cause of war diffusion and coalition participation ${ }^{13}$ The argument proposed here intends to bridge the gap in the

\footnotetext{
${ }^{11}$ Keohane and Nye, 1977, p. 8; Baldwin, 1985, pp. 366-7; Hirschman, 1945: Copeland, 2015. Bennett, Lepgold, and Unger, 1994: Snyder, 1997

${ }^{12}$ An exception to this is Snyder (1997, pp. 166-8). Snyder devotes a portion of his book to examine how military dependence affects intra-alliance bargaining power when it comes to alliance management.

${ }^{13}$ Refer to Chapter 2, for a more thorough literature review. See Siverson and King (1980) on alliances and the diffusion of war, and Newnham (2008) for how economic linkage led to participation in the COTW.
} 
literature, and the theory argues that alliances and economic linkage are but two sides of the same coin: dependence. This shift in framing the issue enables us to realize that alliances are but one avenue through which one state can be reliant on another for its security, and that economic linkage is one of many methods of being dependent on another for one's economic prosperity.

It is equally important to understand beforehand, that the proposed theory is not about dependence leading to alliance formation, but it causing IMC participation. Being able to make the distinction between IMCs and alliances will enable us to take alliances as a measure of dependence, rather than an outcome in and of itself. Alliances between asymmetric states will make a smaller state more dependent than its larger partner on the security provided through the arrangement. Thus, if dependence indeed leads to IMC participation, we should witness alliances having a significant effect as a measure of dependence.

The alliance and war diffusion literatures have indeed demonstrated that alliances are highly correlated with the diffusion of war ${ }^{14}$ However, one problem with such findings are that the theoretical bases for explaining why alliances matter are often insufficient. On the other hand, the dependence argument I propose should prove to be significant to the extent that it provides a more coherent causal mechanism for how and why alliances lead to a higher probability of going to war for an ally.

The relationships I focus on here are essentially patron-protégé relationships. Such dyads are often referred to as 'asymmetric alliances.' However, this often used term restricts the realm of dyads to those that have pre-existing alliance agreements. An alliance agreement is only one of many modes of dependence. Framing the relationship in this manner limits the discussion, and restricts the theoretical implications we can derive from dependence. States do not necessarily

\footnotetext{
${ }^{14}$ Most and Starr, 1980; Siverson and Starr, 1990
} 
need to have a military alliance agreement with each other to establish a patronprotégé relationship. Alliances are but one part of a larger picture. Dependence (economic and security related), is what causes IMC participation.

\subsection{Coalitions and Alliances}

The alliance literature is further inadequate at answering the questions this project seeks to answer because the phenomena I am interested in are simply not alliances. The temporary coordination of military troops in the Korean and Vietnam Wars are International Military Coalitions, not alliances. While several of the coalition members may have indeed been allies, the coalition itself is not an alliance.

Consequently, the question is not about how alliances are formed, but about what leads states to participate in coalitions. In order to address the question of what causes states to participate in International Military Coalition(IMC)s, we first need to understand what IMCs are, and, what they are not.

IMCs are not alliances. Alliances are agreements that consist of contingent promises. On the other hand, coalitions are distinct forms of cooperation between states that entail specific and immediate action. In an IMC, there is no stipulation of a contingent event or circumstance that triggers a predefined and promised response. The distinction between the two concepts is crucial. Therefore, the discussion here first starts with a short review of alliances. This is due to the fact that IMCs are often incorrectly considered to be either the same as alliances, or a subset thereof.

There is no dearth of literature regarding alliances. The subject is well established with numerous works examining various aspects of alliances: from the fundamental question regarding its formation and maintenance, to numerous 
topics such as its impact on states' security, and its affects on war initiation and participation.

Despite the wide use of the word and vast interest in the subject, most IR scholars agree that there is no widely accepted definition of the term. This leads to almost any serious study intending to deal with the subject of alliances to take it upon itself to define the term before it proceeds. Perhaps due to this lack of a commonly accepted definition, there are two common conflations that frequently occur when dealing with the idea of alliances. The first is to conflate a number of different fields of interest, and the second is to conflate coalitions with alliances.

The first conflation has to do with the sphere of political phenomena an alliance addresses. Most of the definitions regarding alliances focus on mutual benefits and general cooperation, and seldom restrict the concept to only military/security related benefits. However, as individual units within the international system, states can cooperate with each other across a breadth of multiple fields. They can agree to form exclusive free trade zones with one another, promise aid to one another, make arrangements to make investment in each others' economies more accessible, transfer technologies, or promise to cooperate on military security. Since an alliance is one form of cooperation between states, it also then, can consider multiple fields. Most scholarly definitions of alliances though, are implicitly referring to military alliances in actuality. These are alliances that focus on military cooperation between states with the goal of enhancing the security of one or all states involved. For instance, regard the following definitions of alliances:

Alliances are formal associations of states for the use (or nonuse) of military force, in specified circumstances, against states outside their own membership 15

${ }^{15}$ Snyder, 1997, p. 4. 
Alliances can be defined as formal associations of states bound by the mutual commitment to use military force against non-member states to defend member states' integrity. ${ }^{16}$

An alliance is based on a written, mostly voluntary, formal agreement, treaty, or convention among states pledging to coordinate their behavior and policies in the contingency of military conflict ${ }^{17}$

... written agreements, signed by official representatives of at least two independent states, that include promises to aid a partner in the event of military conflict, to remain neutral in the event of conflict, to refrain from military conflict with one another, or to consult/cooperate in the event of international crises that create a potential for military conflict ${ }^{18}$

Notice that none of the definitions above explicitly state that they are defining military alliances as opposed to general alliances. However, the contents of the definitions make it clear that they are indeed referring to the former. Hence, in order to avoid conflating other forms of alliances with military alliances, further use of the term should be explicit as to which type of alliance is being addressed. More specifically, any definition and use of the term should clearly state the realm of political phenomena an alliance is considered with. For instance, Bergsmann (2001) explicitly states that a military alliance is

an explicit agreement among states in the realm of national security in which the partners promise mutual assistance in the form

\footnotetext{
${ }^{16}$ Gärtner, 2001, p. 2.

${ }^{17}$ Krause and Singer, 2001, p. 16.

${ }^{18}$ Leeds, 2003, p. 429, citing Leeds et al., 2002, p. 238.
} 
of a substantial contribution of resources in the case of a certain contingency the arising of which is uncertain 19

Due to this first reason, alliances are also often conflated with (political) alignment. The lack of a widely accepted definition, in combination with the failure to recognize that alliances are actually referring to military alliances in most instances, cause alliances to be conflated with alignment.

Political alignment is any general commitment for cooperation between states, whereas, an alliance refers to a specific form of alignment with more formality and specificity. ${ }^{20}$ First, alliances are formal. This is because they are based on formal agreements and/or treaties (usually written documents). Second, alliances are specific. This is because they delineate certain contingencies and a pre-defined action to take place when such an event arises. General commitments for cooperation, i.e., alignment, are neither.

Political alignment between states usually does not entail having a written treaty binding states formally to each other. It is more akin to a general understanding between states to cooperate across a broad spectrum of fields. Alliances are distinct due to the existence of such formal agreements. These usually take the form of a (written) treaty ${ }^{21}$ An essential component of this agreement is the existence of a specific promise. An alliance arrangement entails its member states pledging to take certain actions in the case that some pre-defined contingency happens in the future (i.e., the casus foederis) ${ }^{22}$ Alignment, on the other hand, does not delineate such specific circumstances and actions.

An additional conflation that is more pertaining to the work contained here, is the fact that military coalitions are more often than not vaguely understood as

\footnotetext{
${ }^{19}$ Bergsmann, 2001, pp. 26, 36.

${ }^{20}$ Krause and Singer, 2001, p. 16.

${ }^{21}$ Bergsmann, 2001, pp. 34-6; Krause and Singer, 2001 p. 16; Snyder, 1997, p. 4.

${ }^{22}$ Bergsmann, 2001. pp. 34-6; Krause and Singer, 2001, p. 16; Snyder, 1997, p. 4.
} 
just another form of alliance behavior. Coalitions, when they are indeed recognized to differ from formal alliances, are still described and understood within the framework of alliances. Such descriptions include explanations of coalitions as ad hoc, or temporary, alliances. In some cases, a coalition will even be referred to as just a larger form of alliance ${ }^{23}$ However, just as formality and specificity distinguish alliances from alignment, uncertainty and action distinguish coalitions from alliances.

An alliance is a promise of action. However, an alliance is not the action itself. In an alliance agreement, states promise to take certain actions when some contingency arises. Whether or not the casus foederis for such action will actually arise is uncertain, and subsequently, whether or not a state will indeed honor its commitment (in the form of some action) as previously agreed upon in an alliance agreement, becomes a subject of suspicion. This is the central problem and dilemma that leads to concerns regarding an alliance partner's reliability. 24

On the other hand, a coalition refers to a body of states coordinating their actions. Coalitions are formed with immediate purposes. A coalition comes into existence with the decision of each participating state to act regarding a specific event, at some (more or less) defined time. ${ }^{25}$ Hence, there is no uncertainty regarding the actions of a state participating in a coalition. The act of participating in a coalition is not a promise for action, but is the action itself ${ }^{26}$

Most of the alliance literature fails to make this distinction. The conflations

\footnotetext{
${ }^{23}$ Bennett, Lepgold, and Unger, 1994; Baltrusaitis, 2008: Ashraf, 2011; Snyder, 1997. p. 12.

${ }^{24}$ See Smith, 1995, p. 418; Leeds, 2003, pp. 429-36; Siverson and King, 1980, pp. 1, 3-5, 13, for discussions of alliance reliability.

${ }^{25}$ Bergsmann, 2001, pp. 34; Krause and Singer, 2001, p. 16; Snyder, 1997, p. 16.

${ }^{26}$ Some works in IR indeed notice this distinction. For example, Werner and Lemke $(1997$. p. 530) note that "whereas a formal alliance often promises some form of support against some unspecified opponent, the decision to assist a disputant in an ongoing dispute actually delivers aid against a specific opponent." However, even in this case, they go on to refer to such phenomena as "alignment choice," rather than coalition participation.
} 
happen both in theoretical and empirical work. For instance, Walt (1987)'s seminal work on the formation of alliances starts by explicitly conflating several levels and types of state to state cooperation into one:

I use the terms alliance and alignment interchangeably ... an alliance is a formal or informal arrangement for security cooperation between two or more sovereign states. ${ }^{27}$

Furthermore, due to the lack of the distinction, Walt considers incidents of Arab states coming together to act in coalitions, such as in the Six Day War and October War, as instances of alliance formation, rather than coalition participation.28

Despite the fundamental difference between military alliances and military coalitions, the confusion between the two distinct concepts is, to some extent, understandable. Military alliances contain the promise to act. Hence, when the actual need to honor a previous commitment arises, the subsequent action can easily be mistaken as the promise. Making a bet with someone, and actually paying it up when you lose, are deeply related actions. However, in strict terms, the payment is not the bet itself. The fact that military coalitions are in many cases the resulting products of alliances adds to the confusion and difficulty in distinguishing the two concepts apart. ${ }^{29}$ The pre-defined behavior written in an alliance agreement usually entails that the signatories come to the military aid of one another. Hence, it could be said that the agreement of an alliance commitment often materializes into military action through a coalition.

In order to understand this better, consider three hypothetical states: $A$, $B$, and $C$. Suppose that states $A$ and $B$ have established a mutual defensive

\footnotetext{
${ }^{27}$ Walt, 1987, p. 12.

${ }^{28}$ Ibid. pp. 150-51.

${ }^{29}$ Tago, 2007, p. 180
} 
alliance agreement with each other, formally stating that they will coordinate military action in the case that another third party, state $C$, attacks either one of them. When the casus foederis arises, which is when $C$ attacks either $A$ or $B$, and provided that both parties of the alliance are reliable and respect the previous promises they made, then a military coalition of states $A$ and $B$ will be formed to deal with threat $C$. While this subsequent coalition of forces is a realization of previous commitments, it is not the commitment itself.

The reason why military coalitions are often confused with alliances should become even more apparent upon considering Figure 1.1. The simple two-by-two figure includes a few historical examples of war participating/non-participating states, and the relationship between coalitions and alliances. Each cell contains a pairing of two states, and a war in parentheses. The columns across indicate whether or not the states were in an alliance prior to the war. On the vertical, rows delineate whether or not the states acted together in a coalition in the respective war. There are several cases of states not having an alliance and not fighting together. Accordingly, the lower right cell simply refers to there being multiple cases in this category.

Figure 1.1

Alliances and Coalitions

\begin{tabular}{c|c|c|}
\multicolumn{1}{c}{ Alliance } & No Alliance \\
\cline { 2 - 3 } Coalition & US-UK (Kosovo) & UK-Russia (Crimean) \\
US-UK (Gulf) & US-Turkey (Korean) \\
\cline { 2 - 3 } No Coalition & US-UK (Vietnam) & - \\
& & $($ multiple) \\
\hline
\end{tabular}


Any time two states participate in a war together on the same side, the subsequent grouping of such states can be considered as a military coalition. The pairing of states along the upper two cells of Figure 1.1 can be considered as coalitions of states. The United Kingdom not only had an alliance agreement with the US, but also fought along its side in both the Gulf War and the air campaign in Kosovo. However, not all instances of coalition behavior is preceded by the involved states having an alliance agreement with each other. The pairing of states in the upper right cell had no previous alliance agreement with each other, but they still formed a military coalition to fight together. On the other hand, not all states that do have an alliance agreement successfully form a coalition either (refer to the lower left cell). Despite having an alliance agreement with the US, Britain did not participate in the Vietnam War.

Figure 1.1 demonstrates that military coalitions are not solely bound to alliances, or are a subset thereof. Alliance arrangements are neither necessary, nor sufficient for two states to form a military coalition. Assuming that alliances are sufficient for coalition participation would render the entire debate on the reliability of alliances irrelevant ${ }^{30}$ Neither is an alliance a necessary prior condition for coalition participation ${ }^{31}$ States without an alliance agreement may find it useful to temporarily combine forces to target specific and immediate goals.

Thinking of coalitions as phenomena bound to alliances also induces us to order the two temporally: intuitively, we consider alliances as preceding coalitions. On the contrary, these two events often occur the other way around. The experience of working together in a military coalition could spark the desire and/or need to form a previously inexistent formal alliance. In other instances, a major power coalition leader may require another state's participation in its

\footnotetext{
${ }^{30}$ Consider the lower left cell of Figure 1.1. Also, refer to Siverson and King (1980), Leeds (2003), and Smith (1995) regarding the subject of alliance reliability.

${ }^{31}$ Consider the upper right cell of Figure 1.1.
} 
current military endeavor as a prerequisite of consenting to an alliance agreement. The temporal order of events in some cases indeed show that coalitions occasionally preceded the formation of alliances. Greece, Turkey, Australia, and the Philippines did not have formal alliance agreements with the US prior to their participation in the Korean War. Their alliances with the US were formed concurrently with, or shortly after, their participation in the Korean War effort.

Even in instances where an IMC appears to be the realization of an alliance agreement, i.e., a state participates in an IMC led by another that it has a former alliance agreement with, the circumstances under which it participated and the nature of the IMC itself must be considered with scrutiny. In many cases, states are not 'fulfilling' their alliance terms, but going out of their way to assist an ally. Going to the aid of an attacked partner that one has a defensive alliance commitment to is indeed an instance of a state honoring a previous agreement. This is true as long as the casus foederis that triggers a state's aid has indeed occurred. However, if the partner in question has not been attacked per se, and the casus foederis for forming a coalition for war has not occurred, then the story is totally different.

In the absence of the occurrence of any event that was predefined in an alliance agreement that is meant to send a state to the aid of another via war, we cannot simply point to an alliance as the cause of a state's participation in the coalition. Most current alliance agreements are defensive, and not offensive. Hence, alliance agreements can not be used as the explanation for states' participation in offensive IMCs. If a state does indeed participate in such an IMC led by a partner, it can be considered to be going 'above and beyond' their original commitments.

The point is illustrated more concretely using the previous hypothetical situation of states $A, B$, and $C$. Let us assume that $C$ has attacked $B$, and $A$ gets 
involved on $B^{\prime}$ s side due to its previous commitment towards $B^{\prime}$ s defense. Into the mix, let us now consider another state $D$. $D$ has a defensive alliance with $A$, but not $B$. In strict terms, if $D$ joins in the $A-B$ coalition, it can not be considered as $D$ 'fulfilling' its alliance terms since a) it does not have an alliance with $B$, and b) its alliance terms with $A$ are defensive.

The fact that $A$ is aiding $B$ in its defense against $C$, does not constitute a defensive situation for $A$. Therefore, from $D^{\prime}$ s perspective, withholding from contributing to $A$ 's military endeavor would not constitute a failure to meet its defensive alliance requirements to $A$. In this situation, if $D$ does decide to participate in the $A-B$ coalition, it is in effect going 'above and beyond' its obligations to $A$.

This aspect of 'going above and beyond' one's obligations is what makes the question of coalition participation fascinating. It warrants a nuanced approach, that keeps in mind that coalitions are distinct. Furthermore, understanding that coalitions are distinct from alliances means that the questions we ask must be about coalition participation, not alliance formation.

\subsection{Conclusion: Plan and Overview of the Project}

We witness dependence influencing individuals and groups constantly in our everyday lives. Employees are dependent on their employers for their job security, and politicians on their electorate. The dependence in such relationships lead employees and politicians to go above and beyond what is required of them in an attempt to secure certain benefits: an employee performs tasks beyond their job description to impress their boss, and politicians travel the nation shaking hands and kissing babies. 
In this project, I argue that IMC participation can be understood with such logic. The argument is proposed and tested in the remainder of this study as follows:

In the next chapter, I first start with a more detailed literature review of alliances and war diffusion. This is done to the extent to which it pertains to the subject of coalitions, and it also identifies where they fall short in explaining coalition participation. Most of the shortcomings are not due to any inherent flaws in the arguments per se, but due to the lack of understanding that one needs a separate mechanism to explain coalition participation rather than alliance formation and/or war diffusion.

The chapter then bridges the gap in the current literature, and builds on previous arguments to propose a theory of IMC participation based on dependence. This not only brings previous arguments together into one, but possibly provides more explanatory power. Based on the main argument, a simple game is constructed to demonstrate the validity of the logic, and hypotheses are constructed so that subsequent analyses can test the feasibility of the propositions made.

Following the theoretical focus in Chapter 2, the third chapter proceeds to test the arguments using a newly coded original measure of IMC participation. The analyses focus on six US-led wars post WWII. Logit models are used to test three competing arguments: Dependence, Balance of Threat, and, the Opportunity and Willingness framework. The dependence argument finds the most consistent and substantive support, with all of the findings supporting the expectations laid out by the theory in Chapter 2.

The fourth chapter illustrates the causal mechanism working through the contrast of two states in separate periods. First, the South Korean case focuses on the lead up to their participation in the Vietnam War. South Korea was highly dependent on the US for both its economic sustenance and security. Accordingly, 
it considered participation in Vietnam as a means of deriving economic benefits and allaying security concerns. The state negotiated its participation vis-à-vis the US to maximize the related benefits it hoped to gain.

Brazil in the Korean War period is a case in which the state did not participate on the US' behalf. However, a closer look at the situation shows that the state viewed the crisis as an opportunity to receive concessions from the US, but was severely restricted by its domestic situation. Brazil's domestic political situation limited president Vargas' policy choices, but the narrative shows that the president nevertheless aimed to use the possibility and promise of taking action in the Korean War as a means of gaining economic benefits from the US.

Chapter 5 transitions the project from the primary question of what causes IMC participation to an equally compelling question. If states indeed participate with the expectations of receiving rewards, are they right to do so? An important aspect of this question is the matter of time. If states are rewarded in some manner for their participation as expected, the duration of such rewards are important. Are rewards temporary and last for only the duration of a conflict, or does the act of demonstrating one's allegiance to a patron through IMC participation lead to a long-lasting aid relationship?

I argue that the answer lay in the former. This is attributed to the politics of inattention expected from patron states in asymmetric relationships. Patron states are more than likely to be larger than their protégés, leading to an asymmetric condition $\sqrt[32]{2}$ The asymmetric condition make patrons less attentive to their protégés, than the protégés are to them. It also fills a patron's plate with more domestic and international issues to concern itself with.

To test this argument, the chapter considers the relative changes of military aid during and after four US-led conflicts. The results show that compared to

\footnotetext{
${ }^{32}$ Womack, 2016
} 
non-participant states, participant protégés indeed see a relative increase during a conflict. However, it also finds that the relative change is not permanent. Any distinction they witness in comparison to non-participant states wear away once an IMC event ends.

The final chapter concludes the project by providing a summary of the arguments and findings. It also discusses the contributions of the study, its policy implications, and proposes several directions through which the research could be continued, expanded, and applied. 


\section{Chapter 2}

\section{Coalitions and Dependence}

This chapter proposes an explanation for IMC participation based on economic and security related dependence. It starts with a definition of IMCs, and moves on to a review of the current literature on alliance formation and war diffusion, including recent works that have implicitly touched on the subject of IMCs in their empirical work. It then focuses on dependence and its relationship with IMC participation, and proposes detailed mechanisms through which the former leads to the latter. The cogency of the theory is illustrated through the construction of a simple game between two actors, and I also discuss the difference between dependence and hierarchy in international relations. 


\subsection{International Military Coalitions}

The US Department of Defense(DoD) define coalitions as 'arrangements between two or more nations for common action' and multinational forces as 'forces composed of military elements of nations who have formed an alliance or coalition for specific purposes. 1 1 On the same subject of coalitions, Krause and Singer (2001, p. 16) and Bergsmann (2001, pp. 34-6) respectively characterize coalitions as 'the commitment of two or more states to coordinate their behavior and policies in order to perform particular functions or pursue specific goals,' and being 'formed in anticipation of a decision that will take place for certain at a more or less known point of time.'

From such definitions and characterizations, we find that at the most basic level, coalitions are considered to

- be consisted of two or more states,

- have a specific purpose,

- entail a common action,

- and have a specific timeline.

Like alliances, coalitions are a broad concept that includes several fields of action. The defining characteristics of a coalition are so broad that it could capture a wide range of activities involving a group of two or more states. These can range from cooperating to impose and enforce economic sanctions (e.g., US-led sanction efforts on Iran and North Korea) to UN-led peace keeping operations (e.g., South Sudan), and all the way to multi-national-force inter-state war efforts (e.g., Vietnam and Iraq etc) $2^{2}$

\footnotetext{
${ }^{1}$ US JCS, 2010, pp. 39, 178.

${ }^{2}$ Also refer to Bensahel (2006) for why this distinction in different types of coalitions are important.
} 
In order to avoid the conflation of several types of coalitions hindering further discussion, I propose to focus primarily on military coalitions in inter-state wars. This is for a couple of reasons. The first is that most of the literature in the alliances sub-field have implicitly been focusing on military alliances. This is perhaps because it is the most pertinent to our focus on state and international security. Military coalitions, specifically those for war that entail assured combat action (as opposed to those for peace maintenance), are arguably those that are the most pertinent to the immediate security of a state. ${ }^{3}$ In part due to this first reason, the second reason is that states will accordingly consider participation in such military coalitions with the utmost caution. This is because such efforts require the highest level of commitment from any participating state: the lives of their troops.

International Military Coalitions, hereafter shortly referred to as simply IMCs or coalitions in most instances, are defined as military forces composed of military and/or civilian support personnel from two or more nations that are currently participating in an interstate war, or are deployed with the anticipation of participating in such an event within a reasonable timeframe, within which those forces are deployed primarily for combat or combat related activities that have a high likelihood of being exposed to combat and becoming the subject of fatalities. Admittedly, the definition is long, but necessary. Some components of the definition are discussed in further detail below.

First, IMCs refer to a group of military and military related forces from two or more states. This does not include instances in which a state acts in an inter-state

\footnotetext{
${ }^{3}$ While this is not to imply that peace maintenance operations do not hold within them the inherent possibility of some of those involved becoming subject to violence, the goal and main anticipated behavior of a state's troops are principally different. Troops deployed to a war are most certainly sent for the primary purpose of participating in combat, whereas those deployed to a peace operation are prepared for it. Also see Joyce, Ghosn, and Bayer (2014, pp. 219-20) and their argument for their scope conditions on focusing on certain Militarized Interstate Dispute(MID)s.
} 
war alone. Neither can a war where only the military forces of the two primary belligerents involved be considered to have had an IMC in it. For example, the Falklands War, between Britain and Argentina in the year 1982, is an instance where the conflict was contained to only two actors, hence there are no IMCs.

Second, IMCs may have a number of different stated purposes. These can range from regime change, to conflict resolution, and other such goals. However, in order for a coalition to be considered an IMC, it is required to partake in an inter-state war, or be assembled with the intent of participating in one. Participation in inter-state wars require the highest levels of commitment from a state..$^{4}$ This is due to the assurance, or high likelihood, that its participant forces will be exposed to combat. Participation in peacekeeping operations are different by nature because a peace arrangement is usually in place prior to the deployment of forces. While the possibility of combat is present in such operations as well, the main purpose is not for combat, but for the maintenance of an already established peace. Therefore, such missions and coalitions are not considered to be IMCs 5

Finally, financial and material support for IMCs do not qualify as participation. This is due to the fact that the military and/or civilian personnel of that state do not participate in, or are subjected to a high possibility of being exposed to, combat. For example, several states elect to support war efforts by providing supplies and resources, or grant access to their territory (e.g., provision of military basing rights) exclusively to one side in a conflict.

\footnotetext{
${ }^{4}$ Similarly, Joyce, Ghosn, and Bayer (2014. pp. 206, 220) limit their empirical evaluation to military events and do not include economic and/or diplomatic interventions. Terming their scope conditions "serious events," they justify this by stating that they expect intervention decisions to be more important in such events.

${ }^{5}$ See Tago (2007) for a study on different types of military coalitions and how it impacts states' decisions to join.
} 
The major point in which military coalitions stand apart from alliances is that the former are formed with a goal of immediate action, whereas the latter are contingent commitments of action towards future events (that may or may not happen). Hence, the mechanisms that lead to the decision of participating in military coalitions should be distinct from those that lead to forming an alliance. This is due to the immediateness of the act and its related costs.

The distinct nature and characteristics of IMCs require us to modify the questions we ask about them. The puzzles generated by the alliance literature, while related to some extent, do not apply directly. For instance, some of the alliance literature focus on the function of alliances: the role that alliances play in revealing future intentions of states. Relatedly, this leads to how credible such intentions are (alliance reliability), and how much of an effect such states' intentions have on war prevention.

Alliances provide their respective members, and their potential aggressors, with the revelation of information regarding future intentions. The fact that two (or more) states elect to form an alliance provide a hint at the likelihood of intervention and provision of military assistance to each other in potential conflicts. Although such contracts are not enforceable, the act of formalizing the commitment itself is regarded to be sufficient in revealing information about future incentives ${ }^{6}$ The conveyance of this information is viewed as a means of hindering potential aggressors from engaging in war with states that possess such extended deterrent commitments from others.7

However, the anarchic characteristic of the international system prevents any such agreements from having an enduringly binding effect. This is because there

\footnotetext{
${ }^{6}$ Leeds, 2003, pp. 427-28.

${ }^{7}$ A game theoretic model provided by Smith $(1995$. pp. 408, 410) demonstrates that the formation of an alliance has an effect on the behavior of states regarding war. When the costs of forming an alliance, and failing to honor those agreements are considered, the greater the cost of the latter, ceteris paribus, potential aggressors should be deterred.
} 
is no central authority in the system to enforce states to honor their previous agreements. ${ }^{8}$ Anarchy makes promises and contracts between states problematic. This is what enables the continuous occurrence of wars in the face of multiple existing alliances. Smith (1995, p. 418) accounts for this anomaly by theorizing on the reliability of alliances. Being agreements and promises by definition, the fact that there are different levels of reliability in alliances and their members is a direct by-product of anarchy. Scholars have identified an array of possible causes that determine the differing degrees of reliability across alliances.

First, the nature of the agreement is considered to change the probability of a state respecting its commitments when called to do so. Alliances are not created equal. Some may be defensive, while others may be a mere agreement to not partake in aggressions against each other. Based on such differences, some propose that such types of alliances change their levels of reliability $\mathrm{g}^{9}$ Leeds 2003 , p. 429) distinguishes alliances into five different types, according to the form of agreed upon future action to be taken by its alliance members. First, defensive cooperation commits states to aid each other when either one of them is the target of aggression from another third party. Second, offensive cooperation commits states to join each other in case one decides to become the aggressor against another third party. In neutrality and non-aggression alliances, states agree to refrain from violence against each other, and consultation agreements refer to alliances that do not necessarily promise direct military assistance, but only promise indirect aid through diplomacy and informative methods. 10

The ability to distinguish between different types of alliances have produced some interesting results. For example, Leeds finds that potential challengers are .47 more likely to initiate disputes when they are part of an offensive alliance, and

\footnotetext{
${ }^{8}$ Mearsheimer, 2001; Waltz, 1979 .

${ }^{9}$ Leeds, 2003

10 Ibid. p. 429.
} 
that potential targets are .28 less likely to be targeted when part of a defensive one 11

The reliability of alliance commitments may also be affected by member state attributes and exogenous factors. Building on the observation that some alliance partners join in on wars, but many more do not, Siverson and King (1980, pp. 1, $3-5,13)$ conduct an analysis of inter-state wars and war participation in $1815 \sim$ 1965 , and find a strong correlation between the characteristics of specific alliances and the probability of war participation. More specifically, they find that states are more likely to join their allies in war when '(1) many of their allies are in the war; (2) the allies they join are minor powers; (3) they have relatively few alliance partners; (4) the alliance in question is a defensive alliance; (5) their alliance is relatively new; and (6) they have a relatively large number of alliances. ${ }^{12}$ The results demonstrate that, in addition to alliance types, the attributes of the aided and assisting states, and those of the conflict itself all have significant impacts on alliance commitment compliance.

Coalitions are distinguished from alliances in that the decision to participate is not intended to reveal the future intentions of a state. Reliability is not an issue for coalitions. The decision to participate in a war through a coalition reveals the immediate interests of states. At best, it could possibly provide indirect evidence of a state's future interests. This aspect of coalitions stand in contrast to the debate on the reliability of alliances. Even in well defined alliance agreements that specify what actions a state will take and under what circumstances it will aid another, the fact that such promises are not the actions themselves can lead to deviation when actually called upon to do so.

\footnotetext{
${ }^{11}$ Leeds, 2003, p. 436.

${ }^{12}$ Siverson and King, 1980, p. 1.
} 
Provided that an alliance relationship exists beforehand, rather than think of revealing future intentions then, it is better to think of coalition participation as a mechanism through which states can reveal their reliability to an alliance partner or, when no prior alliance existed, to a potential future alliance partner. In the case that an alliance agreement existed prior to participating in a military coalition, a state may utilize the opportunity to reveal its willingness to respect its alliance commitment in the future. It is not revealing its future intentions per se, but rather revealing the reliability of already stated such intentions. In other words, it could be considered as a method of assurance.13

This aspect of coalition participation leads to an important implication. The type of military coalition does not necessarily need to correspond to the preagreed upon type of commitment contained in an alliance. States may participate in offensive coalitions when they only had a defensive alliance with the coalition leader. This could be done with the goal of revealing their reliability and 'worthiness' as an alliance partner. Empirically, the US has formed multiple military coalitions after WWII that did not address the goal of defending itself directly. Under such circumstances, several allied states went 'above and beyond' the expected defense agreements that their alliance with the US required, and participated in those coalitions. Snyder refers to this as 'assurance' in alliance politics. He states that while promises create new commitments, assurances merely convey information about one's prior intentions 14

A variant on the promise is the "assurance." Assurances are to promises as warnings are to threats. Assurances are statements to friends and allies that one is committed, by one's own interest, to aid them whether or not a formal promise has been given; promises,

\footnotetext{
${ }^{13}$ Snyder, 1997, p. 36.

${ }^{14}$ Ibid. p. 36.
} 
on the other hand, generally create a commitment by engaging additional values. Unlike promises, which establish new commitments, assurances merely convey information about one's prior intentions ${ }^{15}$

\subsection{Balance of Threat and War Diffusion as Possible Explanations of IMC Participation}

Then what causes states to participate in coalitions? The previous section briefly suggested the possibility that states may participate in order to provide assurance to others. If that is the case, we need to further understand the circumstances under which states would feel the need to assure another through such extreme measures.

Despite the apparent dearth of literature regarding the phenomena of IMCs, many studies have indeed (albeit unknowingly) pondered this matter. The catch is that most studies refer to their subject as alliances, when they are actually considering and explaining coalitions. Another well established research program is that of war diffusion. In the broader picture, IMC participation is indeed a form of joining an ongoing war. Hence, it should not be difficult to apply the arguments of this literature to IMCs as well. The main causes contemplated in such works include a variety of factors, but unsurprisingly, previous alliance commitments are often considered to be a strong predictor of willingness, i.e., the probability of joining an ongoing war.

Accordingly, I first focus mainly on Walt (1987) and Joyce, Ghosn, and Bayer (2014) to address these two programs. Because each are respectively considering alliances and war diffusion as opposed to IMC participation, their theories and findings are applied liberally throughout the discussion so as to apply to IMC

\footnotetext{
${ }^{15}$ Snyder, 1997, p. 36.
} 
participation. Therefore, any and all limitations identified should not be taken as a critique of the associated arguments per se, but as further indication of the fact that we are in need of the ability to discern coalitions from alliances, and address coalitions as coalitions.

\subsubsection{Alliance Formation as a form of Balancing Threats}

Walt argues that the main cause of alliance formation for regional powers is to balance threats. ${ }^{16}$ Building on the balancing versus bandwagoning debate in international politics, he shrewdly points out that previous debates are based on aggregate power, and not the perception of threat ${ }^{17}$ The immense contribution he makes is that his theory provisions the perception of threat as a propelling force for smaller states to exhibit balancing behavior. This stands in contrast to major powers balancing against aggregate capabilities. In other words, the ability to define 'the basic hypotheses in terms of threats rather than power alone' helps to paint a 'more complete picture of the factors statesmen consider when making alliance choices. 18

Within this framework, Walt postulates that factors such as aggregate power, geographic proximity, offensive power, and aggressive intentions influence a state's perception of threat. ${ }^{19}$ The case studies in chapters three and four of his book focus on the changes in alliance commitments between Middle Eastern states, and those of their alignments with the two major powers (i.e., the US and Soviet Union) in the period of $1955 \sim 1979$. His vast account includes three dozen instances of alliances, which lead him to conclude that 'balance of threat theory is superior to balance of power theory,' when examining the

\footnotetext{
${ }^{16}$ Walt, 1987, pp.18-9, 148-72.

${ }^{17}$ Ibid. pp. 18-26.

${ }^{18}$ Ibid. p. 26.

${ }^{19}$ Ibid. pp. 22-6.
} 
behavior of regional powers ${ }^{20}$ However, he does acknowledge that it is difficult to distinguish between the importance of each of the four sources of threat perception, and states that 'an increase in any of these factors should make balancing behavior more likely. 21

Despite claiming to have found support for all four sources of threat, Walt seems to place the most emphasis on the combination of aggregate power and geographic proximity $\left[{ }^{22}\right.$ Furthermore, he maintains reservations on the findings regarding the effects of offensive capabilities and aggressive intentions. He attributes this to the difficulty of measurement, and the fact that the former concept is often closely related to aggregate power and geographic distance. ${ }^{23}$ In addition to his main theme of balancing threats, Walt also devotes attention to the impact of ideological solidarity on alliance formation. For ideology, he concludes that it only plays a 'limited role' in the choice of alliance partners, and that there is 'less to ideological solidarity than meets the eye' because it only causes alliances when other significant sources of threat are absent, or when ideology itself is perceived to be the threat ${ }^{24}$

Applying these arguments and findings to IMC participation is quite straightforward. In his own empirical work, at least five of the thirty-three alliances considered are actually coalitions 25

\footnotetext{
${ }^{20}$ Walt, 1987, p. 172, Also see his summary table, "Alliances formed in response to external threats," provided in pp. 150-1 of his book.

${ }^{21}$ Ibid. p. 172.

$22 \overline{\text { ibid. }}$ p. 153.

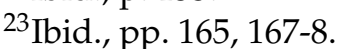

${ }^{24} \overline{\text { Ibid. }}$ pp. 203, 214-7.

${ }^{25}$ Refer to his table, "Alliances formed in response to external threats," in Walt (ibid. pp. 150-1). According to the definition of alliances that Walt premises his study on, the Suez War Coalition, Kuwait Intervention, Six Day War Coalition, Eastern Command, and October War Alliance, are all indeed alliances. However, using the distinction between alliances and coalitions set forth earlier in Chapter 1. it should become clear that these are IMCs, and discrete from alliances as we have come to understand them here.
} 
First of all, we should see states joining military coalitions that are aimed at threats approximate to themselves. Following Walt's focus on distance and aggregate power, it is expected that states will balance against states closer to itself, and with more aggregate power, by participating in a coalition opposite that state. Even when the leader of that coalition is a major power, we expect states in the region of a war to rather side with that state than assist its neighbor to balance against the major power's aggregate power. For example, given that Poland perceives a conflict close by in Kosovo as a source of some threat to itself, it would elect to side with the US to reduce that threat, rather than balance against the US' aggregate power and intervention.

Second, there should be no necessary association between the regime type of a coalition leader and the members that join. When a major power elects to intervene in a conflict, we should not see 'birds of a feather flocking together. ${ }^{26}$ For instance, according to Walt, democracies should have been no more likely to join the US' efforts in the Persian Gulf in 1991, than autocracies. The expectations derived from Walt and his Balance of Threat argument are summarized into three hypotheses in Figure 2.1.

\subsubsection{Willingness, Opportunity, and the Diffusion of War}

Along with alliances, the topic of war diffusion is also the subject of much debate, and it has also produced some interesting empirical findings. Here, I mainly focus on the arguments and recent analyses set forth by Joyce, Ghosn, and Bayer, because they not only provide a well rounded summary of the previous theories regarding the research program, but also successfully utilize a

\footnotetext{
${ }^{26}$ Walt, 1987, p. 212, also see Gartzke and Gleditsch (2004), Gibler and Wolford (2006), and Lai
} and Reiter (2000). 
Figure 2.1

Balance of Threat and IMC Participation

- BoT-H1: Facing an IMC event, states closer to the location of the conflict are more likely to participate.

- BoT-H2: Facing an IMC event, states are more likely to join an IMC when that IMC targets a state with more aggregate power.

- BoT-H3: Facing an IMC event, states closer to the IMC leader's regime type are no more likely to participate than those farther from the leader's regime type.

sophisticated survival model that has several implications somewhat applicable to the questions we are interested in here. ${ }^{27}$

Building on the earlier works of Siverson and Starr (1990), Joyce, Ghosn, and Bayer (2014) concisely summarize the "Opportunity and Willingness" argument as

Opportunity is whether a state can join a conflict, and willingness is why they join 28

Joyce, Ghosn, and Bayer expand upon Siverson and Starr's focus on borders(opportunity) and alliances(willingness) to include a state's material capability as an additional indicator of opportunity, and, alliances and regime type, as indicators of willingness. ${ }^{29}$

\footnotetext{
${ }^{27}$ For an earlier study on the impact of alliances on war diffusion see Siverson and King (1980). Also see Most, Starr, and Siverson (1989) and Most and Starr (1989) for earlier formulations of the "Willingness and Opportunity" argument, and Siverson and Starr (1990) for earlier statistical tests of the theory.

${ }^{28}$ Joyce, Ghosn, and Bayer, 2014, p. 209, also see Siverson and Starr (1990, pp. 48-50).

${ }^{29}$ Joyce, Ghosn, and Bayer, 2014. pp. 211-12, 215-19, their study also include previous rivalries and the presence of a major power as additional indicators of willingness. For the purposes of this study, I focus on the elements presented here.
} 
They use a competing risks duration model (two separate Cox proportional hazard models) to measure the risk (probability) of joining an initiator, and that of joining a target, using Militarized Inter-state Dispute(MID) events from 1816 to 2001. This approach involves a 'triadic' approach: their observations involve measuring potential joiner states' relationships with each of the two initial belligerents in a war. The aim of their model is not only to determine which side a state joins, but also to determine when they join. However, for the purposes of the argument here, I focus solely on the former 30

Opportunity is the possibility of conflict. ${ }^{31}$ As understood by Siverson and Starr (1990), and Joyce, Ghosn, and Bayer (2014), a state first has to be capable of war in order to join in on an ongoing conflict. Hence, the closer it is to a conflict, the more 'opportunity' it has to take part in it. A state's material capability also determines its level of opportunity. States with higher levels of power are more likely to use their power in a conflict if it has the intentions of doing so. Proximity and power should hence be understood as the potential a state has to intervene, regardless of its intentions. Cambodia and Laos may very well have had no intentions of being part of the conflict in Vietnam, but ultimately been caught up in it because of their high levels of opportunity (contiguity). In other words, these states were part of the Vietnam War because they could, not necessarily because they wanted to do so.

Using CINC scores adjusted for distance to each of the initial belligerent sides, Joyce, Ghosn, and Bayer find that states that can contribute more to either side are more likely to join one of the initial belligerents. ${ }^{32}$ More specifically, their two model approach also enables them to compare the effects on joining initiators and targets. With the distinction, they find a larger effect on the probability

\footnotetext{
${ }^{30}$ Joyce, Ghosn, and Bayer, 2014, pp. 206, 219-221.

${ }^{31}$ Ibid. p. 208.

32 Ibid. pp. 223, 227, 229.
} 
of joining a target. This is interpreted as evidence supporting Walt's Balance of Threat argument and Joyce, Ghosn, and Bayer state that 'if initiators target weak states, ... lends support to the notion that third parties join the target in an attempt to balance against a more powerful initiator.' Geographic proximity also finds support. Using binary measures of contiguity to the initial belligerents, they find that states closer to a conflict are more likely to join in a war ${ }^{33}$

Willingness is the motivation for partaking in a conflict, the why of this two sided coin ${ }^{34}$ Joyce, Ghosn, and Bayer find that having either defensive or offensive alliances with an initial belligerent increases the probability of intervening in a war on behalf of that belligerent ${ }^{35}$ However, why the presence of having a defense pact with an initiator leads to an increase in a state's likelihood of cooperating in war is left somewhat ambiguous. ${ }^{36}$ They note that the distinction between types of alliances are often 'blurry,' and that having an alliance may show evidence of sharing common views of foreign policy 37

Unlike Walt's assertion that 'birds of feather do not flock together,' Joyce, Ghosn, and Bayer find that regime type and previous rivalries are associated with the diffusion of war. For regime type, they find that states closer to an initiator's regime type are more likely to join its side, but do not find the same effect for targets ${ }^{38}$ For rivalries, they find that having such a relationship with one of the initial belligerents will increase a state's probability of joining the opposite side. 39

\footnotetext{
${ }^{33}$ Joyce, Ghosn, and Bayer, 2014, pp. 224, 227, 229-30.

${ }^{34}$ Ibid. pp. 208-9.

35 Ibid. pp. 217, 233-35.

${ }^{36} \mathrm{Or}$, why the presence of having an offensive alliance with a target leads to participation. 37 Joyce, Ghosn, and Bayer, 2014, p. 234.

38 Ibid. pp. 217, 231-33, also see Reiter and Stam (2002). For democracies, they attribute this to the fact that democracies are more selective in choosing the wars they fight.

${ }^{39}$ Joyce, Ghosn, and Bayer, 2014, p. 218, 235.
} 
Applying the arguments and findings of opportunity to IMC participation is quite straightforward: more powerful states and those closer to a conflict will be more likely to join an IMC.$^{40}$ Materially capable states will do so because they can, compared to states less capable that want to, but can't.

On the other hand, the willingness arguments focus on alliances and regime type. In other words, the argument is focused on the affinity between a potential war participant and the initial belligerent it will aid. First, states with a regime type more similar to a warring state will decide to participate in a coalition to support it, and second, states with an alliance with a warring state will be more likely to support it through a coalition. An important point in understanding this argument is that the regime type and alliance status is measured from the initial belligerent, not a major power leading an IMC. For example, according to the propositions derived from the opportunity and willingness framework, we are interested in the proximity of regime type and presence of an alliance between South Vietnam and Australia, not the latter state's relationship to the US.

The expectations derived from the Opportunity and Willingness framework are summarized into three hypotheses in Figure 2.2.

\subsubsection{Towards Synthesis: Alliance Dependence, Economic Link- age, and Changing Focus}

In addition to regime type and alliances, Joyce, Ghosn, and Bayer also examine the effect that major powers have on the likelihood of other states joining a conflict. Termed 'Previous Major Power Joining,' they consider 'how the prior

\footnotetext{
${ }^{40}$ The point about geographic proximity leads to the same prediction as hypothesis BoT-H1 derived from Walt in the previous section. A separate hypothesis for this point is thus not generated here.
} 
Figure 2.2

Opportunity, Willingness, and IMC Participation

- OW-H1: Facing an IMC event, states with more material power are more likely to join.

- OW-H2: Facing an IMC event, states with regime types closer to the subject of an IMC are more likely to join.

- OW-H3: Facing an IMC event, states that have an alliance with the subject of an IMC are more likely to join.

joining by major powers influences the willingness of other third parties to join. $\sqrt[41]{41}$ The theoretical argument set forth is that states may believe that the side a major power joined is more likely to win, and that they may additionally expect to receive benefits from the major power in return for joining its side. ${ }^{42}$

Joyce, Ghosn, and Bayer wield the Korean War as an example of the importance of considering 'previous major power joining' in evaluating the willingness of states joining ongoing wars. They argue that most states aided the initial target (i.e., South Korea) only after the US joined the war in its assistance. ${ }^{43}$ However, most of the major wars in the post WWII period follow this pattern. Furthermore, it is doubtful if many of those states would have joined the war without the US' involvement. As mentioned in the introduction, what stake in Far East Asia did Ethiopia or Colombia have?

This makes the 'triadic approach' that Joyce, Ghosn, and Bayer use somewhat problematic. I argue that we should focus more on third party states' relationships with major power war participants, rather than their relationships to that

\footnotetext{
${ }^{41}$ Joyce, Ghosn, and Bayer, 2014, p. 219.

${ }^{42}$ Ibid. p. 219.

43 Ibid. p. 219.
} 
of either of the initial belligerents. For example, rather than focus on Ethiopia or Colombia's alliance status and regime type similarity with South and North Korea, I believe that examining those relationships with the US should reveal more about the intentions of such states 44

The US' recent struggles to form formidable military coalitions have also inspired efforts in IR to address the question of IMC participation more directly. However, these efforts have tended to focus on security or economic related factors separately. I focus here on Bennett, Lepgold, and Unger (1994), and Newnham (2008) to highlight these two approaches.

When two states are allied with each other, they face the fears of abandonment and entrapment 45 Abandonment is when an ally either realigns with another state, or fails to help a state against an adversary. On the other hand, entrapment is when the alliance induces a state to become involved in a conflict that is central to their ally's interest, but peripheral to their own. ${ }^{46}$

The alliance dependence hypothesis is that a state will support an ally in war if its own dependence pressures outweigh their fears of entrapment ${ }^{47}$ Bennett, Lepgold, and Unger (1994, p. 71) propose a model of security coalition contribution that integrate both international and domestic level factors. According to their model, international level factors, which are considered as 'external pressures,' form the incentives of contribution to a coalition. Such pressures include collective action, balance of threat, and alliance dependence. ${ }^{48}$ On the other hand, domestic processes such as state autonomy, societal preferences, and

\footnotetext{
${ }^{44}$ Joyce, Ghosn, and Bayer, (p. 238) indeed make a similar proposition for future research. They state that having 'found evidence that the prior participation of a major power influences other third parties' decisions to join, ' 'future research might consider how other characteristics of previous intervenors influences other third parties' decisions.'

${ }^{45}$ Snyder, 1984: Cha, 2000

${ }^{46}$ Bennett, Lepgold, and Unger, 1994: Snyder, 1984: Cha, 2000 p. 265.

${ }^{47}$ Bennett, Lepgold, and Unger, 1994 . p. 44, also see Snyder (1984).

${ }^{48}$ Bennett, Lepgold, and Unger, 1994, pp. 39-40.
} 
bureaucratic politics are theorized to limit the forms of contributions and ability to contribute 49

From the six case studies they consider, they conclude that Germany and Japan's contributions (and to a lesser extent Egypt and Britain's) to the Persian Gulf War are best explained by the alliance dependence hypothesis. ${ }^{50}$ According to their analysis, while Japan contributed nearly thirteen billion dollars to the war effort, it is interpreted to have been mostly in reaction to the state's concern for its relationship with the US rather than due to any concerns with international stability or oil prices $\sqrt{51}$ In a similar vein, it also attributes Germany's twelve billion dollar commitment to the war to pressures from the US Congress, Department of Defense, and Senate 52

In addition to alliance dependence, others have pointed to economic linkage as a possible cause of coalition participation. Newnham (2008) suggests that economic linkage played an important role in motivating states to either join or support the US-led Iraq War coalition (the Coalition Of The Willing - COTW) in $2003{ }^{53}$ He provides narratives of the US using several economic instruments such as economic/military aid, trade/investment etc. as carrots or sticks to persuade and pressure states to support and participate in the COTW.

For instance, Newnham argues that the three states of the former UN Trust Territory of the Northern Marianas (Marshall Islands, Palau, and Micronesia) all joined the COTW because they were highly dependent on US aid and the agreements that regulated this aid had expired. Apparently, negotiations to

\footnotetext{
${ }^{49}$ Bennett, Lepgold, and Unger, [1994, pp. 39-40, also see Barnett and Levy (1991) and Baum (2012) for more on domestic politics conditioning alliance/coalition participation.

${ }^{50}$ Bennett, Lepgold, and Unger (1994) consider the contributions of six states(the US, Britain, Egypt, France, Germany, and Japan) to the Persian Gulf War and interpret the hypotheses' relevance in each case.

${ }^{51}$ Niksch and Sutter, 1991: Bennett, Lepgold, and Unger, 1994, pp. 63-4.

${ }^{52}$ Bennett, Lepgold, and Unger, 1994, pp. 66-7.

${ }^{53}$ Albeit, Newnham (2008) refers to the dependent variable of his analysis as 'alliance formation,' when the study is clearly considered with 'coalition participation.'
} 
extend the agreements happened to be underway in $2002 \sim 2003 \sqrt[54]{5 e}$ argues that those states feared that failing to support US foreign policy would lead to cuts in aid, and that was what led them to join the COTW. ${ }^{55}$ Through such narratives, Newnham concludes that understanding alliance formation(i.e., IMC participation) must include the consideration of economic factors in addition to the conventional focus on threat perception. 56

Both Bennett, Lepgold, and Unger and Newnham provide compelling arguments that can be applied to understanding the cause of military coalition participation. These arguments focus on alliance dependence and economic linkage. However, I argue that these are two different branches of the same tree. In other words, it resembles the story of how six blind men attempt to determine what an elephant is like: the one happening on the trunk understanding an elephant to be like a snake, another one feeling its knee likening it to a tree, and so on. The extant theories and analyses obscure the fact that both alliance dependence and economic linkage are forms of dependence in general.

This is not to suggest that previous findings in the literature are wrong per se, but that the specifications of their dependent variables and scopes of analyses have misled our understanding of IMC participation. This study intends to provide an overarching framework that brings the phenomena of economic linkage and alliances together as two representative sides of dependence.

\footnotetext{
${ }^{54}$ Newnham, 2008, p. 186.

55 Ibid. p. 186.

56 Ibid. p. 198.
} 


\subsection{Dependence and Coalition Participation}

\subsubsection{Dependence}

The concept of dependence, or interdependence, is far from a new idea in international relations and foreign policy. Dependence is where a state relies on another for specific goods or functions $\sqrt[57]{7}$ For the purposes of this study, the reliant state is termed the protégé, and the state that provides benefits the patron. A protégé state is one that depends on another state (the patron) for some resource, service, or commitment, that it believes is essential to its security or economy. Severing a relationship with their patron would give rise to significant opportunity costs ${ }^{58}$ A patron provides its protégé with benefits, and it can have multiple protégés. The fact that a state is capable of being a patron means that it is usually a major power.

This idea of dependence has traditionally been restricted to trade relations, and other forms of interaction between states have been categorized and analyzed separately as social and political linkage. For instance, protectionists and free traders had very different views of how foreign trade affected national power and sovereignty. Hirschman (1945, pp. 14-5) argued that foreign trade can provide a method of coercion between sovereign nations, and termed this the influence effect of foreign trade $\sqrt[59]{5}$ The influence effect of foreign trade is where a protégé state depends on its trade with a patron state because it is either difficult to dispense entirely with the trade they conduct with its patron, and/or it is

\footnotetext{
${ }^{57}$ Keohane and Nye, 1977, p. 8. The original definition for dependence provided by Keohane and Nye is: 'a state of being determined or significantly affected by external forces.' Alternatively, Baldwin (1985, pp. 366-7) defines dependency as 'the opportunity costs of severing a relationship.' The definition I use is modified to allow the possibility of there being varying degrees of dependence.

${ }^{58}$ Ibid. p. 366.

${ }^{59}$ Also see Baldwin's discussions of economic statecraft. Baldwin notes that the 'regulation of foreign trade has been used as a technique of statecraft throughout history.'(p. 206)
} 
difficult to replace the patron as a market or source of supply with others. This creates a situation in which the protégé would do anything in order to retain its trade with the patron 60

However, dependence is not restricted to the economic realm and trade relations. States may also depend on a military alliance for security. Bennett, Lepgold, and Unger (1994, pp. 44-5) confound the economic and security related aspects of dependence in their 'alliance dependence hypothesis.' Incorporating Snyder (1984)'s dilemma of abandonment and entrapment in alliance politics, they argue that a state can depend on an ally not only militarily, but also economically. ${ }_{1}^{61}$ While this is not necessarily incorrect, an accurate depiction is that any state can be dependent on another for either its security, its economy, or for both. Furthermore, a patron does not need to be an ally for a protégé to be dependent. In other words, an alliance, or being an ally, should not be the frame within which we are focusing our analysis, but viewed as a means to the end of achieving security for a state. This distinction is important.

Replacing the term foreign trade for alliance commitment within the context of Hirschman (1945)'s explanation of the influence effect should demonstrate how the concept of dependence is applied to security: The influence effect of an alliance agreement is where a protégé state depends on an alliance commitment from a patron because it is either difficult to dispense entirely with the security provided by the agreement, and/or it is difficult to replace the patron as a source of extended deterrence with another. This creates a situation in which the protégé would do anything in order to retain the promises provided by a patron as defined in an alliance agreement.

\footnotetext{
${ }^{60}$ Hirschman, 1945, p. 17, see Chapter II of Hirschman for an in-depth discussion of trade and influence.

${ }^{61}$ Bennett, Lepgold, and Unger, 1994, p. 44.
} 


\subsubsection{Dependence as the Cause of IMC Participation}

In some instances, patron-protégé relationships are referred to as 'asymmetric alliances.' However, this term is problematic because it restricts the realm of dyads to those that have alliance agreements. An alliance agreement itself is only one mode of dependence among many, and should not be used to frame the discussion. Two states do not necessarily need to have a military alliance agreement with each other to establish a patron-protégé relationship.

A protégé is, by definition, dependent on its patron. Therefore, in accordance with Hirschman's influence effect, a protégé ‘would do anything' to retain the resources, services, or commitments from its patron ${ }^{62}$ This means that it would even participate in an IMC that is of central interest to its patron but not to itself. The participation itself may either be the result of a patron's direct solicitation, or the result of pro-active behavior on the protégé's part.

Through case studies of states and the US during and leading up to the Iraq War in 2003, Newnham (2008) demonstrated that the US used bribery and coercion in order to receive the support of other states in the COTW. The narratives show that the two methods are viable options that a patron can utilize to force a protégé's support.

Direct bribery is when a patron entices a protégé with an offer of some good or service in exchange for its cooperation. Any instance in which the patron makes the protégé's cooperation in an IMC the prerequisite of providing such new services would be considered instances of direct bribery. Offering aid packages previously not considered or offered, establishing free trade agreements, granting preferential trade status etc. are some examples. Coercion on the other hand refers to instances in which the patron threatens to with-hold or discontinue the

\footnotetext{
${ }^{62}$ Hirschman, 1945 , pp. $14-5$.
} 
supply of some service or good unless the protégé participates in its IMC. There is no offering of a new good, but the threat of the suspension of a good that was previously provided is what differentiates coercion from bribery.

In practice however, distinguishing these two active methods of a patron soliciting a protégé's participation in an IMC is not straightforward. What may appear as a bribery may actually have been an act of coercion, and vice-versa. For instance, if a patron and protégé had been pursuing some sort of trade agreement prior to the former's need for an IMC, and within the timeline of negotiations the need arises, the patron may use this as leverage against the protégé. It may promise to yield to terms preferential to the protégé on the stipulation that the latter participates in the IMC. Temporally, the protégé's IMC participation and trade agreement may coincide, making it appear as a bribe. However, the actual act can be considered as one of coercion. On the other hand, the termination of some service provided by the patron to a protégé may coincide with an IMC. While the two incidents are independent, the patron may decide to coerce the protégé's IMC participation by promising to continue the service only if the latter cooperates. Due to the continuation of a service, this may look like coercion on the surface. However, it is actually a bribe since the service would have been terminated anyway. The continuation that is observed is actually the start of a new service.

The protégé is not always merely the subject of a patron's active soliciting behavior. It may also pro-actively seek to participate in an IMC led by its patron. It is possible that some protégés offer their support without any explicit pressure from the patron. Protégés may see the conflict their patron is involved in as an opportunity to 'prove their worth' as a reliable and worthwhile state by going 'above and beyond' to assist them. Such pro-active protégés are driven to contribute to an IMC because they fear that failing to do so will lead to 
reductions in the current level of benefits they are receiving, or because they believe participating will lead to increases in their benefits as a reward.

First, a protégé may be motivated to participate in an IMC out of the desire to maintain the current level of benefits they receive from a patron. When this is the case, it can be because they fear that a failure to participate leads to retribution from the patron, or to the substitution of itself with another potential protégé that does. ${ }^{63}$ The dilemma that such states face resemble the problems of abandonment and entrapment states face in alliances. Protégés fear that they may be abandoned by the coalition leader if they do not contribute on the one hand, and on the other, they fear that they may become entrapped in a conflict that is not central to their own security interests if they do. The balance can be found where they commit to the extent in which the costs of participation do not outweigh the benefits they gain from the continued input of benefits from the coalition leader.

The fears of abandonment for protégé states can be further exacerbated or ameliorated by the exit costs of their respective patron state. Exit costs of the patron are low in instances of severe asymmetric dependence. This is when the protégé is simply dependent on the patron. However, as the relationship moves from pure dependence towards inter-dependence, the exit costs for the patron rise. ${ }^{64}$ When exit costs are relatively high for a patron state, it may be constrained from exacting retribution on the protégé, or substituting it with another. Conversely, when such costs are low, the patron has relatively higher bargaining power in getting its way with the protégé ${ }^{65}$ This does not imply that an explicit bargaining model in which the patron is directly demanding coalition participation of its protégé necessarily needs to exist. The protégé's level of fear

\footnotetext{
${ }^{63}$ Keohane and Nye, 1977, p. 13.

${ }^{64}$ Crescenzi, 2003 , pp. 811.

65 Ibid. pp. 812-3, 815-6.
} 
could stem from the mere knowledge of such exit costs, or lack thereof, to the patron.

The fears of abandonment may also be ameliorated by the existence of alternative patrons available to the protégé. If a protégé perceives that it can successfully replace its current patron with another in order to avoid participation in a costly war, it may decide to do so. However, this may be exceedingly difficult for two reasons.

First, in a situation of bipolarity or multipolarity, the state would have established its patron-protégé relationship with its current patron rather than another for some specific reason. This may be due to ideological distance (e.g., the Cold War period), geographic proximity, shared history, etc. Whatever it was that caused the state to initially decide to align with its current patron would make it difficult to change to another.

Second, regardless of polarity, sunk costs may make changing patrons exceedingly difficult and costly. Establishing the necessary networks and infrastructure for the transfer of resources or services from a patron are sunk costs that a protégé could not retrieve when electing to change to another patron. Additionally, establishing new networks and infrastructure, or adjusting current ones to accommodate another patron brings with it prospective costs that are possibly more costly than incurring the costs of participating in an IMC to some degree. Such costs would also be greater the longer the relationship between the patron and protégé 66

Protégés may also be motivated to participate in an IMC by a desire to increase their future benefits. In the case of alliance commitments, they may do so to increase the probability that their patron will indeed follow through with

\footnotetext{
${ }^{66}$ Refer to Crescenzi (2003)'s discussion of adaptation costs and economic exit.
} 
defending them if a crisis arises ${ }^{67}$ Shortly put, they may be trying to increase the reliability of the alliance. A protégé may see the conflict its patron is involved in as an opportunity to 'prove their worth' as a reliable and worthwhile state by going 'above and beyond' to assist them.

In relation to economic benefits, protégés may view an IMC as an opportunity to expand its production and global reach with the in-direct assistance of a dominant patron in the system. Due to the patron's ability to provide a protégé, or multiple protégés, with several resources and services, it is highly likely that it is a major power in the international system. A state with such status in the system could not only reward another directly, but convince others within the system to interact with it on higher levels, for example, in the form of increased trade. Also, as witnessed in Japan's production boom during the Korean War, and Korea's during Vietnam, states can capitalize on military procurements as a way to 'jump start' their economy. ${ }^{68}$ While the rewards and increased benefits from a patron are important, such secondary benefits may be even more so to participant protégés.

Along with trade and manufacturing, foreign direct investment (FDI) is yet another form of rewards-begetting-rewards a patron could use to benefit a compliant protégé. FDI is not only a possible source of growth to a protégé through direct benefits, but the capital accumulation can encourage new inputs from others, promote technological advances, and produce spillover effects to a protégé's own domestic firms 69

While FDI itself is carried out by private firms and not the state, studies have shown that international agreements on trade and investment can also

\footnotetext{
${ }^{67}$ Joyce, Ghosn, and Bayer, 2014, p. 219.

${ }^{68}$ Schaller, 2004 p. 148; Moon and Lim, 2001. p. 208.

${ }^{69}$ deMello, 1997: Globerman, 1979: Iamsiraroj, 2016.
} 
influence FDI in addition to the attributes of a recipient's economy. ${ }^{70}$ When all else is equal in the endowments or institutional infrastructures of candidate recipient protégés, a patron could make one state more attractive than another to its private sector through trade agreements, tax benefits, etc.

In addition to current protégés, a state that is not currently a protégé but desires to become one may view an IMC as an opportunity to establish a relationship with a patron. Such states may participate with the expectation (or, with a stated promise from the patron) of receiving such benefits as compensation. States may not act with the intention of becoming dependent per se, but in order to increase trade with a patron that is an economically dominant state in the system, receive economic and/or military aid from it, or establish an alliance agreement with it. For instance, several states' NATO accession dates coincide with participation in IMCs primarily led by the US. Turkey participated in the Korean War with combat troops and became a NATO member in 1952. Poland, Hungary, and the Czech Republic all gained member status shortly before the Kosovo air campaign of 1999 to which they all immediately made contributions ${ }^{71}$ Many of the states that signed on to be part of the US COTW in the initial Iraq campaign also exhibited such behavior. Several of the states had pending NATO memberships on the line, or were actively seeking membership in the organization. ${ }^{72}$

Figure 2.3 presents an IMC participation decision making model based on dependence, present/future benefits, and expectations. The model is derived from the various points argued above, beginning with a state questioning itself if it is dependent on a patron or not. The patron is assumed to be facing war

\footnotetext{
${ }^{70}$ Morrissey and Rai, 1995. Refer to deMello (1997) for a survey of theories regarding the effects and determinants of FDI allocation.

${ }^{71}$ http://www.nato.int/cps/en/natohq/nato_countries.htm

http://www.nato.int/history/index.html

72 http://usatoday30.usatoday .com/news/2003-02-25-unwilling.htm.
} 
imminently or already be waging war, and either be open to the participation of others on its behalf or actively soliciting the participation of others. 
Figure 2.3

Decision Model of Coalition Participation Based on Dependence

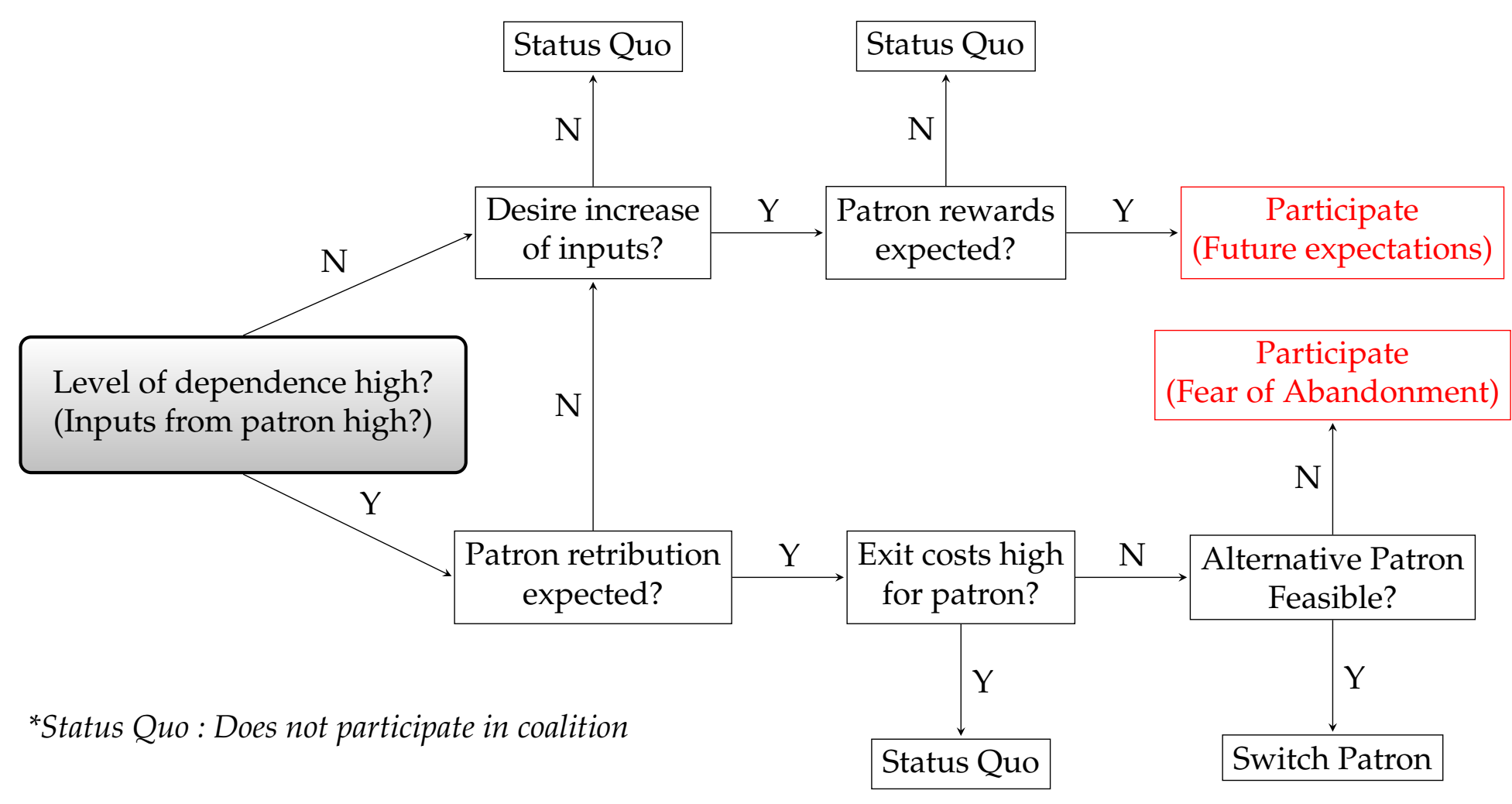




\subsubsection{Rewards, Reputations, and the Shadow of the Future}

As in alliances, the question of reliability also arises from dependence and IMC participation. Even if a protégé participates with a promise from its patron that it will be rewarded in some manner, there is no guarantee that the patron will follow through. From the patron's viewpoint, it would actually make more sense to receive a protégé's contributions and then shirk the responsibility of rewarding it. Knowing this, a protégé would accordingly refuse to contribute, leading to only one outcome in which there would be no rewards and no participation.

However, we do observe protégé participation. This is because the transaction is not a one time deal. International reputation costs and the probability of future war events prevent a patron from shirking its responsibilities towards cooperative protégés. Reputation is a shared perception about a state's prior behavior that is used to predict future behavior. ${ }^{73}$ A major power patron will anticipate itself to be involved in more wars into the future. The state will accordingly need to ensure the participation and cooperation of its protégés and others in future events. Shirking from rewarding promised benefits to cooperative protégés will set a precedent that cooperation will go unrewarded to other protégés in the system, hence leading to difficulty in future IMC events. This study is agnostic to the reasons for why states build IMCs to wage war in the first place, rather than fight it alone. However, as we have witnessed in multiple US-led operations in the past half century, it was and continues to be, a recurring method of war. ${ }^{74}$

\footnotetext{
${ }^{73}$ Miller, 2012, p. 37, also see pp. 36-8 of Miller (ibid.) for his discussion on how this definition differs from Mercer (1996, p. 6)'s; the main distinguishing factor being character/disposition versus behavior.

${ }^{74}$ See Tago (2005) and Corbetta and Dixon (2004) for discussions and studies on the determinants of multilateralism. Also see Larson et al. (2003) for an in-depth analysis of inter-operability of multi-national forces at the operational level.
} 


\subsubsection{Means and Ends: Dependence Types and Modes}

When characterizing a state to be dependent on another (i.e., to be a protégé), it means that it relies on its patron for some specific good or function. For example, an important function that military alliances provide its member states with is the revelation of information. More specifically though, it means that member states use the information of future intentions to enhance their security. In other words, the alliance agreement itself is not the end game, but a means to the end of achieving enhanced security.

The distinction between means and ends extend to the economic realm as well. States do not engage in foreign trade or receive economic aid from other states as an end in and of itself, but do so to increase their own economic wealth. The action of engaging in trade is the means of achieving the ends of creating and maintaining a prosperous economy.

Likewise, when discussing dependence, we need to be able to distinguish the means through which a state is dependent on another, from the ends for which a state is so. In short, we need to distinguish the means and ends of dependence. ${ }^{75} \mathrm{I}$ assume that the primary interest of states are to ensure their survival, and thus that they strive to a) increase their level of security, and b) increase the strength of their economy. ${ }^{76}$ Concomitantly, there are two primary types of dependence: security dependence, and economic dependence. The type of dependence refers to the ends for which a state is dependent on another. Within each type of dependence, there can be several modes of dependence. A mode is a way or manner in which something occurs. Therefore, a mode of dependence is the means through which a state is dependent on another. In the

\footnotetext{
${ }^{75}$ Refer to Baldwin (1985, pp. 15-8) for an alternate discussion of means and ends.

${ }^{76}$ Similarly, Lake (2009. pp. 9-10) formulates his theory of hierarchy across the two dimensions of economic and security policy.
} 
case of a state relying on its ally, it is more accurate to state that it is dependent on the alliance agreement (which is the mode of dependence; the means) for itself to achieve a higher level of security (the type of dependence; the ends).

Economic Dependence. Protégés that are more economically dependent on their patrons will be more likely to participate in IMCs led by that patron. While several modes of dependence can be found within the dimension of economics, the most notable and constant one is perhaps trade. States that predominantly trade with one partner may fear that their partner will divert trade to others if they fail to assist them when needed. Baldwin (1985, p. 206) noted that the regulation of foreign trade has been used as a technique of statecraft throughout history. While this implies a coercive use of trade as a foreign policy tool, the mere knowledge that such options are available to a patron may lead protégés to take the initiative to stay in good standing with their patrons.

H1: When a patron state builds an IMC, protégés that have higher levels of trade with that patron are more likely to participate.

Security Dependence. Alliance commitments, and the stationing of a patron's troops are all modes of security dependence. First, states that depend on a patron's defensive alliance commitment for their security may attempt to secure the reliability of that commitment through demonstrating their own reliability as a partner through IMC participation.

H2: When a patron state builds an IMC, states that have a defensive alliance commitment from the patron are more likely to participate than those that do not. 
Second, a patron may deploy its troops to a protégé to protect it, or their own interests in the region. The semi-permanent stationing of troops on another's soil is significantly different from the deterrent effect that an alliance agreement provides due to the tangible physical presence of one's troops on the ground.

From the protégé's perspective, a patron's troops not only provide an immediate deterrent to its neighbors, but also provides an added military capability to its own. When its patron is faced with war in another region, a protégé may fear that the patron will be faced with the need to pull out troops stationed on their soil to supplement the effort. Therefore, it may be willing to send its own troops instead to preserve a certain level of their patron's presence on their soil during the war.

\section{H3: When a patron state builds an IMC, protégés with more of the patron's troops stationed on their soil are more likely to participate.}

One-Off Rewards and Deals. In addition to the continuous relationships discussed above that fall into one category, states may also be interested in noncontinuous, instant rewards and deals that could fall into either. States may use their participation in an IMC as a negotiation tool in order to receive concessions from the major power leading the effort. Such negotiations may have been ongoing before an IMC event, or may happen during one. States may see the IMC as an opportunity to gain some political, economic, or security related concession from the IMC leader as compensation for their support and participation. 77

Such deals for participation are distinct from the previously discussed economic and security related measures of dependence because they are not concerned with an established continuous transaction with the patron. However,

\footnotetext{
${ }^{77}$ Also see Joyce, Ghosn, and Bayer, p. 219
} 
they are nevertheless highly related because they could lead to changes in such measures in the future.

For instance, a state may have wanted to establish a trade agreement favorable to itself with an IMC leader. Once an IMC event presents itself, it may attempt to negotiate that agreement with the leader in exchange for its participation. While the deal itself is distinct from trade dependence, it may lead to increased levels of trade between itself and the leader into the future. Other examples of such deals include the designation of a state as a preferred trading state, or the patron using their influence within an international economic related institution to admit a state into its ranks.

Such deals may also be purely political. The nature of the IMC leader being a major power may make other smaller states in the system highly sensitive to how they believe it perceives them. If such states believe that there is the potential for the IMC leader to later take issue with them, they may try to preempt such actions by demonstrating good-will towards it with their participation.

For instance, tensions started to mount between South Africa and the US in the latter 1940s as the newly elected National Party in the former country increasingly promoted apartheid policies and clashed with the United Nations regarding its claims on Namibia. $\sqrt{78}$ However, South Africa's participation in the Korean War in 1950 eased these tensions and softened pressure from the Truman administration. ${ }^{79}$ More importantly, not only did their participation help ease tensions, but South Africa immediately used the opportunity to further their nuclear program. Just two weeks after the start of the war, the South African government approached the US for assistance with its nuclear energy program.

\footnotetext{
${ }^{78}$ Lulat, 2008 pp. 142-5.

${ }^{79}$ Ibid. p. 145.
} 
The US consented and offered nuclear technology in exchange for purchasing uranium 80

\subsection{A Game of IMC Participation and Rewards}

The interaction between a patron and protégé can be modeled into an extensive form game. In this game, there are two players, $i$ and $j$, respectively a patron and its protégé. Assuming that the patron has already made the decision to lead an IMC into war, the sequence of the game is structured as such: player $j$ decides first whether or not it will participate, and then player $i$ decides whether or not it will reward $j$ with benefits. Hence, the available actions for player $j$ are $p$ (articipate) or $\bar{p}$ (articipate) (not participate), and for player $i$ they are $r$ (eward) or $\bar{r}$ (eward) (not reward). The total cost of war for either player is defined as, $\Pi_{k}$ (where, $k \in\{i, j\}$ ). The underlying assumption throughout the game is that the goal of both players is to minimize this cost.

\subsubsection{The Costs of War}

When calculating the total cost of war, $\Pi_{k}$, players need to consider several factors. The most immediate and evident cost for a state fighting in a war are the military costs, $\phi_{k}$, associated with the endeavor. Additional factors that contribute to, or that can lessen, the war bill include rewards for participation, the spillover effect of such rewards, international reputation costs, and exit costs.

Figure 2.4 provides a brief summary of the notation regarding the terms to be used in constructing the game. Brief additional descriptions follow below.

\footnotetext{
${ }^{80}$ Lulat, 2008, p. 145.
} 
Figure 2.4

Notation

$\Pi_{k}:$ Total cost of war for player $k\left(\Pi_{k} \in \mathbb{R}\right)$

$\phi_{k}:$ Military cost of war for player $k\left(\phi_{k} \in \mathbb{R}_{0}^{+}\right)$

$\gamma_{j}^{i}$ : Rewards given to $j$ from $i\left(\gamma_{j}^{i} \in \mathbb{R}_{0}^{+}\right)$

$\alpha_{i}$ : Reputation costs $i$ incurs if $\gamma_{j}^{i}=0$ when $\phi_{j}>0\left(\alpha_{i} \in \mathbb{R}_{0}^{+}\right)$

$\omega_{j}:$ Spillover benefits for $j$ when $\gamma_{j}^{i}>0\left(\omega_{j} \in \mathbb{R}_{0}^{+}\right)$

$\epsilon_{i}:$ Exit costs to $i\left(\epsilon_{i} \in \mathbb{R}_{0}^{+}\right)$

Rewards $\left(\gamma_{j}^{i}\right)$. This is the value of rewards a patron gives to a participant protégé. The game does not (and need not) differentiate between whether this is a pure increase of benefits allocated to a protégé for its IMC participation, or if it is a relative increase of benefits due to retributive action taken by a patron to those that do not. The latter case would result in a reduction to protégés that fail to participate, and a continuation of previous levels of benefits flowing to participant protégés would constitute a relative increase. Either way, this value, which is denoted as $\gamma_{j}^{i}$, can be considered to be a cost for the patron that contributes to its overall cost of war, $\Pi_{i}$. On the other hand, for the protégé, $j$, it would decrease the total cost of participating in an IMC.

Spillover $\left(\omega_{j}\right)$. For the protégé, receiving some reward from the patron brings with it additional spillover effects that generate further value. While the patron may decide to only contribute a value of $\gamma_{j}^{i}$, this could give rise to the production of additional benefits to the protégé. The value of these spillover effects are denoted $\omega_{j}$. 
For instance, the stationing of a patron's troops on a protégé's territory may only cost $\gamma_{j}^{i}$ for a patron. However, the additional deterrence provided by those troops may increase confidence in the protégé state and lead to further investment and trade from, and with, other states in the system. In this case, that further investment and trade can be considered the spillover effect, $\omega_{j}$. Another example is that of FDI. The actual cost to a patron regarding FDI may be minimal. But for the protégé, it is expected to lead to additional value in the form of technological advances and spillover effects to domestic counterparts.

Like rewards, spillover effects also negatively impact the total cost of war participation for a protégé. However, they are only generated when rewards are present. In other words, when $\gamma_{j}^{i}>0$ is true. On the other hand, this does not add to the cost of a patron because these added benefits are not directly provided to a protégé by the patron. Such benefits are rather generated from, or originate from, the rewards it did provide. Finally, spillover effects are not expected to be generated for states that rely on unique resources or services(i.e., for protégés that make a patron incur exit costs).

Reputation $\operatorname{Costs}\left(\alpha_{i}\right)$. Protégés participate in patron led IMCs with the expectation that doing so will be beneficial. The patron incurs negative consequences if that expectation is not met. In other words, a failure to reward a participant protégé (when $\phi_{j}>0$ and $\gamma_{j}^{i}=0$ ), cause reputation costs to a patron, which is denoted as $\alpha_{i}$.

These reputation costs are significant and large. The patron is, by its nature, a dominant state in the system; a state that is capable of providing benefits to its protégés, a major power that is invested in the international system enough to feel the need to lead an IMC into war. Hence, it will also anticipate more wars 
into the future. Reputation costs are significant in that it would reduce other states' participation in these future events.

Exit Costs. For some patron-protégé relationships, there exist substantial exit costs, $\epsilon_{i}$, to the patron for severing the relationship. This happens when the protégé possesses unique resources, provides some specialized service, or provides some other distinct value to the patron that can not be replaced with ease. For example, a patron may find difficulty in finding an alternative source of unique natural resources such as oil or uranium, or a protégé may be situated in a strategically important location in which the patron wishes to maintain a certain level of influence. Due to the uniqueness of the resource/service of such protégés, they are not expected to benefit the same as others from spillover effects associated with rewards 81

\subsubsection{Payoffs}

The total cost of war for a patron is given by the equation

$$
\Pi_{i}=\phi_{i}-\phi_{j}+\gamma_{j}^{i}+\alpha_{i}+\epsilon_{i}
$$

and that for a protege is

$$
\Pi_{j}=\phi_{j}-\gamma_{j}^{i}-\omega_{j}
$$

\footnotetext{
${ }^{81}$ Figure A.1 in Appendix A provides a summary of the parameters that can be applied to the relationships between the terms discussed above. These parameters are necessary in understanding the mathematical proof for ordering the preferences of each player.
} 
Let $\Pi_{i}\left(a_{i}, a_{j}\right)$ be the total cost of war for $i$, if it chooses action $a_{i}$, and player $j$ chooses action $a_{j}$. Then, with these parameters, the payoffs for each player according to whether or not exit costs are involved are presented in Tables 2.1. and 2.2 .

Table 2.1

Patron Costs of War

\begin{tabular}{c|c|c}
\hline$\Pi_{i}\left(a_{i}, a_{j}\right)$ & No Exit Costs & Exit Costs \\
\hline \hline$\Pi_{i}(r, p)$ & $\phi_{i}-\phi_{j}+\gamma_{j}^{i}$ & $\phi_{i}-\phi_{j}+\gamma_{j}^{i}$ \\
$\Pi_{i}(r, \bar{p})$ & $\phi_{i}+\gamma_{j}^{i}$ & $\phi_{i}+\gamma_{j}^{i}$ \\
$\Pi_{i}(\bar{r}, p)$ & $\phi_{i}-\phi_{j}+\alpha_{i}$ & $\phi_{i}-\phi_{j}+\epsilon_{i}+\alpha_{i}$ \\
$\Pi_{i}(\bar{r}, \bar{p})$ & $\phi_{i}$ & $\phi_{i}+\epsilon_{i}$ \\
\hline
\end{tabular}

Table 2.2

Protégé Costs of War

\begin{tabular}{c|c|c}
\hline$\Pi_{j}\left(a_{j}, a_{i}\right)$ & No Exit Costs & Exit Costs \\
\hline \hline$\Pi_{j}(p, r)$ & $\phi_{j}-\gamma_{j}^{i}-\omega_{j}$ & $\phi_{j}-\gamma_{j}^{i}$ \\
$\Pi_{j}(\bar{p}, r)$ & $-\gamma_{j}^{i}$ & $-\gamma_{j}^{i}$ \\
$\Pi_{j}(p, \bar{r})$ & $\phi_{j}$ & $\phi_{j}$ \\
$\Pi_{j}(\bar{p}, \bar{r})$ & 0 & 0 \\
\hline
\end{tabular}

\subsubsection{The Game in Extensive Form}

The choices that patrons and protégés face going into an IMC can be represented as a game, with the protégé first deciding whether or not to participate, and the patron making decisions regarding rewards. The game is $\Gamma^{E}=\left(N, S_{k}\right)$, where $N=\{i, j\}$, and $s_{i} \in S_{i}=\{p r, p \bar{r}, \bar{p} r, \overline{p r}\}$ and $s_{j} \in S_{j}=\{p, \bar{p}\}$. The game is 
one of complete and perfect information, and the payoffs are represented as $U_{k}\left(s_{k}, s_{\bar{k}}\right) \cdot 82$

Actors want to minimize the associated costs of war, hence, the larger the payoff, the lower the preference. The related preferences are presented in Figure 2.583

Figure 2.5

Preferences

\section{With no exit costs}

$$
\begin{aligned}
& i: \phi_{i}-\phi_{j}+\gamma_{j}^{i} \succ \phi_{i} \succ \phi_{i}+\gamma_{j}^{i} \succ \phi_{i}-\phi_{j}+\alpha_{i} \\
& j:-\gamma_{j}^{i}+\phi_{j}-\omega_{j} \succ-\gamma_{j}^{i} \succ 0 \succ \phi_{j}
\end{aligned}
$$

\section{With exit costs}

$$
\begin{aligned}
& i: \phi_{i}-\phi_{j}+\gamma_{j}^{i} \succ \phi_{i}+\gamma_{j}^{i} \succ \phi_{i}+\epsilon_{i} \succ \phi_{i}-\phi_{j}+\epsilon_{i}+\alpha_{i} \\
& j:-\gamma_{j}^{i} \succ 0 \succ \phi_{j}-\gamma_{j}^{i} \succ \phi_{j}
\end{aligned}
$$

\subsubsection{No Exit Cost Game}

Players: $\mathbf{N}=\{i, j\}$

Strategy Sets: $S_{i}=\{p r, p \bar{r}, \bar{p} r, \overline{p r}\}$

$$
S_{j}=\{p, \bar{p}\}
$$

Payoffs: $U_{i}(p r, p)=\phi_{i}-\phi_{j}+\gamma_{j}^{i}$

$$
U_{i}(p \bar{r}, p)=\phi_{i}-\phi_{j}+\alpha_{i}
$$

\footnotetext{
${ }^{82}$ The order in which the actors move do not have an effect on the outcome of the games. Refer to Appendix A.

${ }^{83}$ Refer to Appendix A for the mathematical proofs regarding the ordering of the quantities.
} 


$$
\begin{aligned}
& U_{i}(\bar{p} r, \bar{p})=\phi_{i}+\gamma_{j}^{i} \\
& U_{i}(\overline{p r}, \bar{p})=\phi_{i} \\
& U_{j}(p, p r)=\phi_{j}-\gamma_{j}^{i}-\omega_{j} \\
& U_{j}(p, p \bar{r})=\phi_{j} \\
& U_{j}(\bar{p}, \bar{p} r)=-\gamma_{j}^{i} \\
& U_{j}(\bar{p}, \overline{p r})=0
\end{aligned}
$$

The game in extensive form, along with the solution is presented in Figure 2.6. To make it easier to understand the game, the payoffs at the terminal nodes are presented as numerical values that correspond to the order of preferences, as according to Figure $2.5^{84}$

Figure 2.6

\section{Participation and Rewards Game: No Exit Costs}

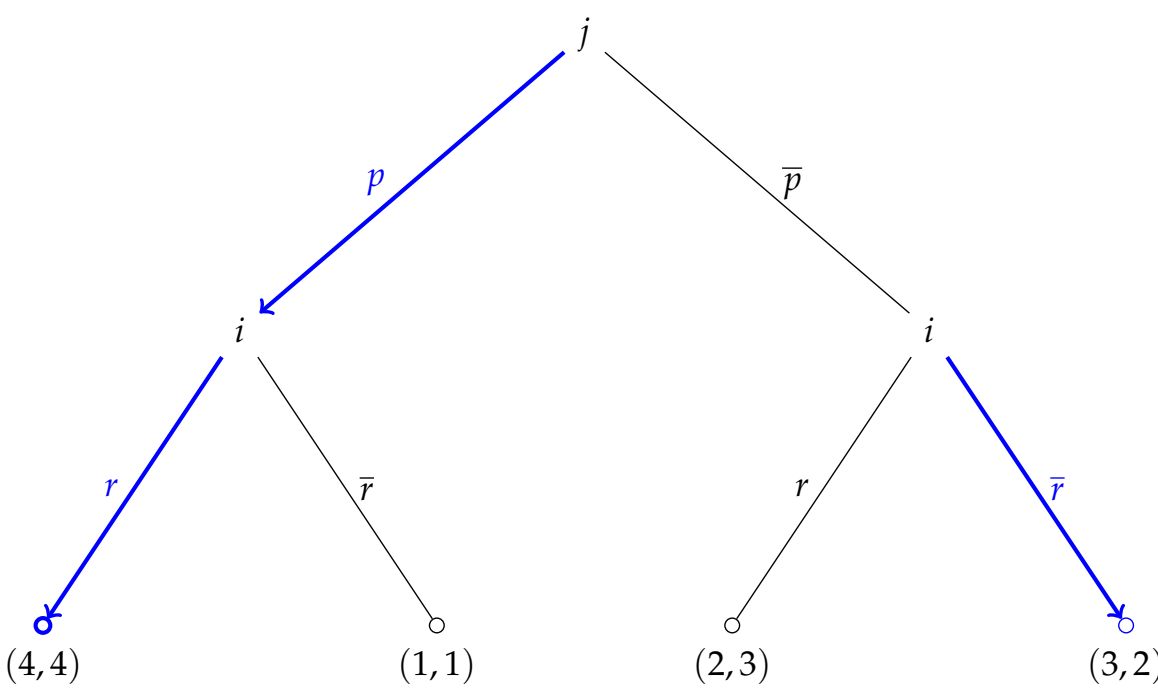

In this game between $i$ and $j$ with no exit costs, the protégé first decides whether or not to participate $(p)$. If $j$ participates, $i$ can either reward, or not $(\{r, \bar{r}\})$. The best response for $i$ at this decision node is to reward, since $\phi_{i}-\phi_{j}+\gamma_{j}^{i} \succ$ $\phi_{i}-\phi_{j}+\alpha_{i}$. In other words, paying the rewards are less costly than incurring the related costs to its reputation. On the other hand, if the protege decides to $\bar{p}, i^{\prime}$ s

\footnotetext{
${ }^{84}$ The same game with the actual payoffs are provided in Appendix A
} 
best response is to $\bar{r}$, since $\phi_{i} \succ \phi_{i}+\gamma_{j}^{i}$. This means that going it alone is better for $i$ than fighting alone and paying the costs of rewards to a non-participant protégé.

Knowing the preferences of $i$, the best response for $j$ is to $p$. This follows because the payoff for $j$ when choosing to $p$ would be $-\gamma_{j}^{i}+\phi_{j}-\omega_{j}$ (since $i$ would choose $r$ ), and be 0 when choosing to $\bar{p}$ (since $i$ would then $\bar{r}$ ), and $\phi_{j}-\gamma_{j}^{i}-\omega_{j} \succ 0$.

Therefore, the subgame perfect equilibrium(SPE) is

$$
\therefore\left(s_{i}, s_{j}\right)=(p r, p)
$$

\subsubsection{Exit Cost Game}

Players: $\mathbf{N}=\{i, j\}$

Strategy Sets: $S_{i}=\{p r, p \bar{r}, \bar{p} r, \overline{p r}\}$

$$
S_{j}=\{p, \bar{p}\}
$$

$$
\text { Payoffs: } \begin{aligned}
U_{i}(p r, p) & =\phi_{i}-\phi_{j}+\gamma_{j}^{i} \\
U_{i}(p \bar{r}, p) & =\phi_{i}-\phi_{j}+\epsilon_{i}+\alpha_{i} \\
U_{i}(\bar{p} r, \bar{p}) & =\phi_{i}+\gamma_{j}^{i} \\
U_{i}(\overline{p r}, \bar{p}) & =\phi_{i}+\epsilon_{i} \\
U_{j}(p, p r) & =\phi_{j}-\gamma_{j}^{i} \\
U_{j}(p, p \bar{r}) & =\phi_{j} \\
U_{j}(\bar{p}, \bar{p} r) & =-\gamma_{j}^{i} \\
U_{j}(\bar{p}, \overline{p r}) & =0
\end{aligned}
$$


The game in extensive form, along with the solution is presented in Figure 2.7. As in the previous game presented in Figure 2.6, the payoffs are in numerical values.

Figure 2.7

\section{Participation and Rewards Game: With Exit Costs}

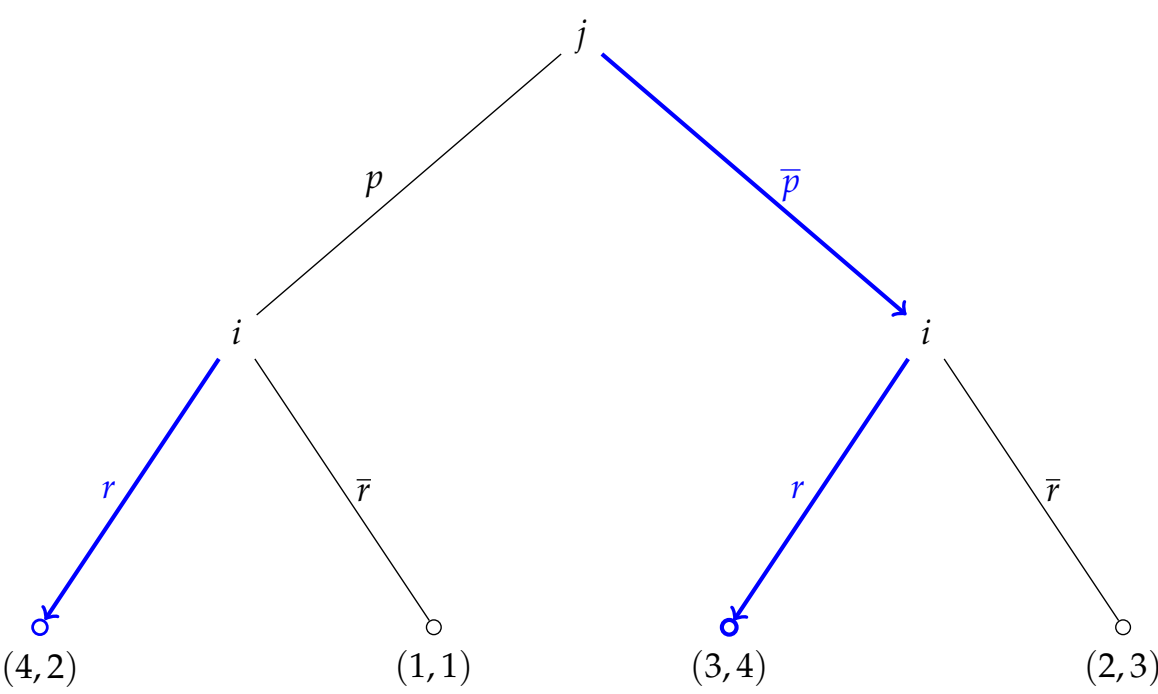

In this game with exit costs, if the protégé $(j)$ participates, the best response for the patron $(i)$ is to reward $(r)$. Upon the participation of $j$, if $i$ does not reward, it will not only incur exit costs for terminating the relationship, but also have to pay the related reputation costs $\left(\phi_{i}-\phi_{j}+\epsilon_{i}+\alpha_{i}\right)$. The combination of the two are more costly then granting rewards $\left(\phi_{i}-\phi_{j}+\gamma_{j}^{i}\right)$. On the other hand, if $j$ does not decide to participate, it is still less costly for the patron to continue to reward the exit cost protégé, due to exit costs being larger than rewards $\left(\phi_{i}+\gamma_{j}^{i} \succ \phi_{i}+\epsilon_{i}\right)$.

Knowing the preferences of $i$, the best response for this type of $j$ is to $\bar{p}$. This follows because the payoff for $j$ when choosing to $p$ would be $\phi_{j}-\gamma_{j}^{i}$ (since $i$ would choose $r$ ), be $-\gamma_{j}^{i}$ when choosing to $\bar{p}$ (since $i$ would then still $r$ ), and $-\gamma_{j}^{i} \succ \phi_{j}-\gamma_{j}^{i}$. In other words, receiving the rewards without paying the cost of war is more beneficial to $j$. Therefore, the SPE in this case is 


$$
\therefore\left(s_{i}, s_{j}\right)=(\bar{p} r, \bar{p})
$$

\subsection{Hierarchy and Dependence}

The proposed theory of dependence and IMC participation does not necessarily mean that the relationship between patron and protégé is hierarchical. Lake (2009, pp. 9-10) theorizes that hierarchy between dominant and subordinate states appear across the two-dimensions of economic and security policy. In this relationship, subordinate states do not balance against their dominant ones, but rather bandwagon with them. This is due to their need to 'demonstrate respect for the authority of their dominant states,' within which their participation in an IMC can be considered to be a 'symbolic act of obedience. 85

The distinction between hierarchy and dependence comes in the difference of the mechanisms, which in turn lead to different sequences in which the main variables are ordered. For Lake, hierarchy itself is what leads to our observing a subordinate state having increased trade with a dominant state. Allowing the stationing of a dominant state's troops on one's soil is also taken to be an indication of hierarchy. In other words, most of the means of dependence discussed in the previous section can be understood in a hierarchical world to be caused by hierarchy, not the other way around.

On the other hand, dependence is the result of being high on these measures. A state becomes dependent on a patron because it relies on the economic and security related benefits it reaps from the relationship. Being dependent on these measures then propels states to participate in patron led IMCs. In contrast,

\footnotetext{
${ }^{85}$ Also see Lake's discussion on subordination and his evidence on state's following the US into war, pp. 167-72
} 
a subordinate's decision to aid a superior state's military efforts are just an additional indication of hierarchy according to Lake. Dependence does not need a hierarchical relationship to exist. There is no need for the 'legitimate authority' of a dominant state over a subordinate. It is a more realist account of dependence as another form of power a patron state has over its protégé that takes the form of economic and security related leverage.

Despite these differences, I do not propose the theory as a counter argument to hierarchy in international relations ${ }^{86}$ The two arguments are not necessarily incompatible, but lay on fundamentally different perceptions of the international system. For Lake, hierarchy is a crucial ingredient. Hierarchy is not only driving IMC participation, but also the stationing of troops, trade, aid, etc. However, for dependence, the latter factors are driving a state's level of dependence, and dependence is in turn leading to IMC participation.

\subsection{Conclusion}

IMCs are distinct from alliances. Therefore, it demands we tailor the questions accordingly when we ask what leads to participation in IMCs. Furthermore, while joining an IMC is still a form of war participation and diffusion, the focus should not necessarily be on the relationship between participant states and the initial belligerents, but on their relationships with the major power leading the charge in an IMC.

I argue that we need to consider dependence on an IMC leader as a cause of war collaboration. This does not entail disregarding conventional factors that are considered to contribute to the probability of war diffusion/participation. The

\footnotetext{
${ }^{86}$ On the contrary, if subsequent tests find supportive evidence, it will even strengthen Lake's argument empirically. This is because most of the outcomes predicted by both theories are similar.
} 
contribution this study endeavors to make is to help expand our understanding of war participation by focusing not only on the war itself, but to the relationship of a potential war participant state and one that is leading the effort. Participation in an IMC is still participation in a war, and the shift in focus does not intend to ignore the conventional factors that have considered to be the causes of war participation.

The argument for dependence as a cause of war participation is not intended to replace such other causes, neither is it claimed to be the sole cause of war participation. What it does require though, is that we consider dependence in addition to such factors as distance, power, and regime type, when considering the phenomena of IMC participation. These other factors and dependence are not meant to be exclusive. It is not the case that the cause of IMC participation must be either dependence or any of the other conventional causes of war. They may, and are expected to, be weighing on a state's decision simultaneously.

Based on the arguments in this chapter, Table 2.3 presents a summary of the different factors leading to IMC participation and the expectations for each, as according to the proposed theory of dependence, the balance of threat, and opportunity/willingness arguments.

An IMC leader refers to the major power that is primarily leading the effort in a military coalition, and the subject of an IMC refers to the state that is receiving the support of that IMC. A target refers to the state with which an IMC is engaging in war with, and a potential joiner the state that is facing the decision of joining in an ongoing or imminent IMC. Unless otherwise noted, the listed factors refer to those of the potential joiner. For example, 'H1: Level of Trade with IMC Leader,' refers to the level of trade a potential joiner has with an IMC leader, and 'BoT-H1: Distance to Conflict' to a potential joiner's distance to a conflict. 


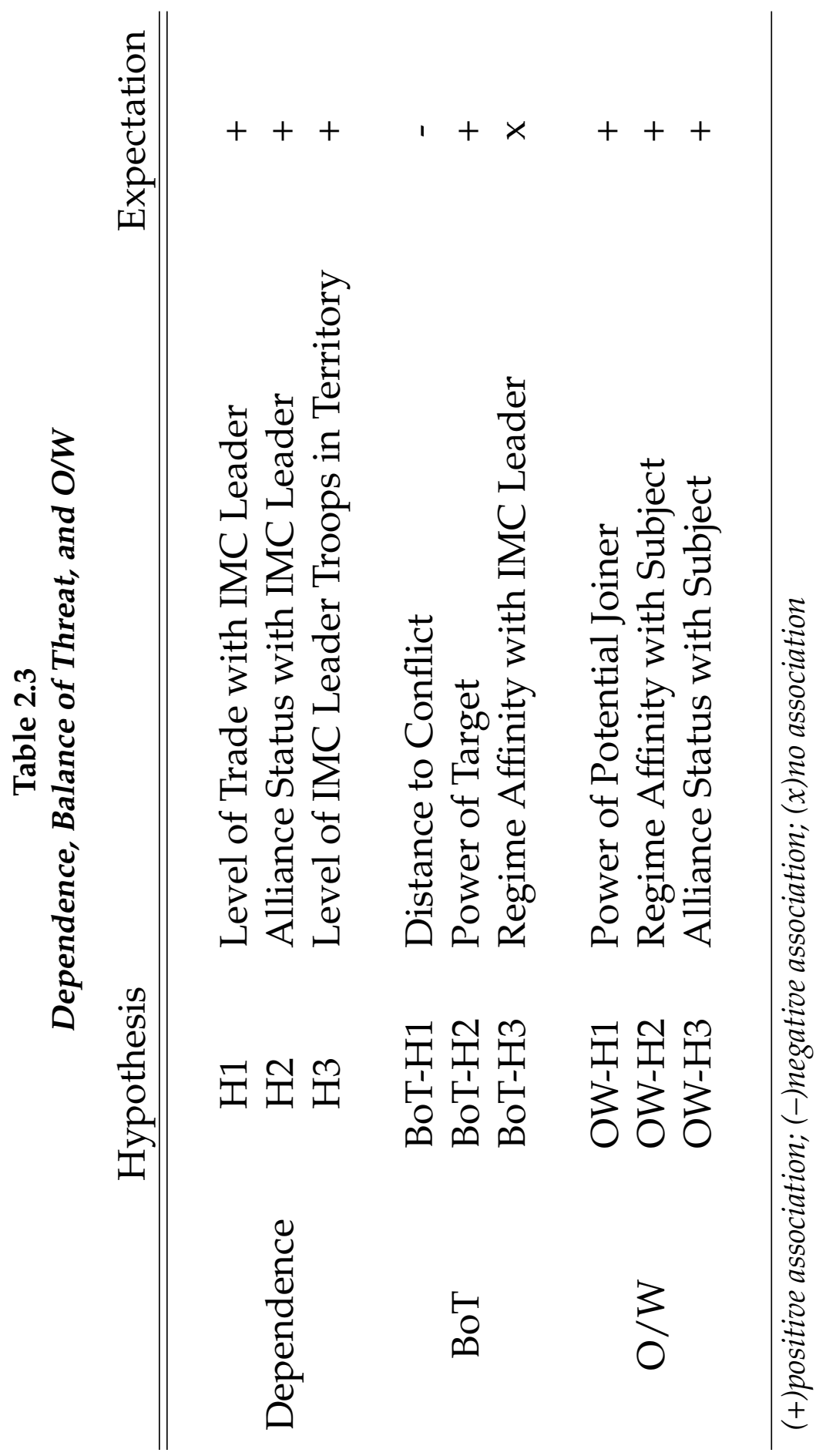




\section{Chapter 3}

\section{Following the US into War:}

\section{Participation in US-led IMCs post}

\section{5}

In this chapter, I test the previously proposed theory regarding dependence leading to IMC participation, against the two alternate explanations of Balance of Threat (BoT) and Opportunity/Willingness(O/W). The logit analyses use original data coded specifically for this project: a binary measure of combat or non-combat support of six US-led IMCs post 1945. 


\subsection{Dependence and IMC Participation}

International Military Coalitions (IMCs) are distinct from alliances. The former is immediate action, whereas the latter is a conditional promise for future action. This distinction means that applying the extant literature on alliance formation, maintenance, and reliability to understanding the cause of IMC participation poses limitations.

Some studies on war diffusion and contagion have found positive correlations between alliances, distance, and war diffusion. Such studies have found that alliance partners and states that are closer to a warring state are more likely to join later into that war. However, these analyses often lack an overarching theoretical argument to explain the causal mechanism between alliances and war diffusion.

I argue that the concept of dependence can bridge this gap. Alliances are but one dimension of the wider array of modes through which a protégé state can be dependent on a patron. Dependent protégés rely on their patron for benefits crucial to their survival. This dependence makes them willing to go the extra mile: go beyond their arrangements with their patrons to secure the current level of benefits into the future, or with the expectation that such actions will bring increases in such benefits.

IMC participation is a form of going above and beyond for protégés. When their patrons are an IMC leader, participant protégés are going out of their way to fight in a war that is apparently not of central interest to their immediate security. Dependence explains the disconnect. Rather than focusing on the opposing sides of a war and trying to find an explanation there, this approach demands we look at states of the same side for an explanation of war participation. 
Focusing on economic and security related dependence provides an explanation for why a state may view a geographically distant war as vital to its central interests. They will find it vital if their patron is fighting in that war through an IMC that needs assistance. Protégés will fight for their patrons to secure economic and security benefits. If the argument is correct, we should see states with higher levels of dependence participating to a greater degree than those that have lower levels of dependence. In this chapter, I test Walt's Balance of Threat, and Joyce, Ghosn, and Bayer's Opportunity and Willingness arguments against the proposed theory of dependence as the main cause of IMC participation.

\subsection{Scope}

The US has played a dominant role in modern coalition efforts and aid provision. It holds a distinctive position in the international economy, has led the most IMCs since 1950 than any other single state (8 out of 17), and provides the most comprehensive and accessible amount of reliable data regarding its trade, aid, and other related transactions with states throughout the system. Additionally, while the UN and NATO are both international organizations, the US arguably played a crucial role in the formation of both, and continues to be a critical member in their maintenance and actions.

For these reasons, the analyses are bounded to US-led IMCs after WWII. Conceptually, this restricts the inferences from all findings and conclusions to the US rather than all major power IMC leaders in general. However, it should not limit the implications they have for the more general subject of dependence and IMC participation. 
The scope of the analyses include six cases of IMCs from 1945 to 2004: the Korean War(1950-53), Vietnam War(1965-75), Gulf War(1990-91), Kosovo Air Campaign(1999), Initial Afghanistan Campaign(2001), and the Iraq Invasion of 2003. The events are based on the CoW MID dataset, with some exceptions to the Vietnam War. ${ }^{1}$ The Vietnam War is closely related to two separate events in the CoW data: the Laotian War, and the Communist Coalition. ${ }^{2}$ I incorporated these latter two events into Vietnam due to concerns that they are endogenous to the conflict in Vietnam. Short narratives regarding the cases are provided below:

\subsubsection{Korean War}

Immediately after the North Korean invasion of its southern counterpart in June of 1950, president Truman authorized General MacArthur to provide a show of force in the following month of that year ${ }^{3}$ China became involved on the North Korean side once US-led UN forces pushed towards the North Korean-Chinese border..$^{4}$ An armistice was signed on 27 July 1953.5.

\subsubsection{Vietnam War}

The US initiated a campaign of sustained bombing directly against North Vietnam following a February 7,1965 North Vietnamese attack on US bases in South Vietnam that claimed eight American lives.6 The formal introduction of US combat troops happened on 8 March, that same year, with the landing of two

\footnotetext{
${ }^{1} \mathrm{CoW}$, Inter-State War Data

${ }^{2}$ War numbers 170 and 176 , respectively, in the CoW data.

${ }^{3}$ Edwards, 2013, pp. 20-1.

${ }^{4}$ Ibid. p. 22.

5 İid. pp. 25-6, Also see Edwards (2006). For a comprehensive historical account of the war itself, refer to Cummings (2010). For an account of the years previous to the war, I recommend Cummings (1990).

${ }^{6}$ Lawrence, 2008, p. 89.
} 
Marine battalions on Danang $!^{7}$ The US' military engagement officially ended with the signing of a peace accord on January 27, 1973, but significant military and economic aid to South Vietnam continued into 19748 As North Vietnam took over the South, president Ford announced that the US had no more to do with the Vietnam War, officially concluding anymore US involvement. 9

\subsubsection{Gulf War}

Following the Iraqi invasion of Kuwait in August 1990, the UN Security Council quickly adopted resolution number 661 imposing a trade and financial embargo on Iraq ${ }^{10}$ Following a four-month build up of forces along the border (Operation Desert Shield), the war (Operation Desert Storm) started with allied airstrikes in January 1991. Forty-two days after the start of airstrikes, president Bush announced the liberation of Kuwait and the defeat of Iraq. All coalition war operations were suspended the following day, on 28 February 1991.11.

\subsubsection{Kosovo Air Campaign}

In reaction to Milosevic's ethnic cleansing in Kosovo of Kosovar Albanians, NATO commenced Operation Allied Force: an air campaign aimed at degrading Serbian capabilities. ${ }^{12}$ The campaign lasted from late March to early June of 1999, with the cooperation of all nineteen of the NATO states at the time and fourteen of those states contributing combat resources. 13

\footnotetext{
${ }^{7}$ Lawrence, 2008, p. 90.

Ibid. pp. 159, 165.

Ibid. p. 167, citing Madden (1975).

${ }^{10}$ Englehardt, 1991. pp. 3, 13, The UN resolution was adopted on the 6th, and the US imposed its own embargo on the day of the invasion, 2 August.

${ }^{11}$ Ibid. p. 72, The narrative for the Gulf War is based on the chronology provided in Englehardt (ibid.).

${ }^{12}$ Peters et al., 2001, p. 16, citing Graham and Drozdiak (1999).

${ }^{13}$ US Department of Defense, 2000, pp. 4, 24, 109, also see Peters et al. (2001, pp. 18-23).
} 


\subsubsection{Afghanistan}

The war led by the US in Afghanistan started within a month of the 9/11 terror incident of 2001. Primarily consisting of US special forces troops and air strikes, the initial campaign of Operation Enduring Force(OEF) lasted for the latter three months of that year with the goal of toppling the Taliban regime. Operations continued into the next year with the addition of coalition forces provided by the United Kingdom, Canada, and Australia, and by March of 2002, the multi-nation coalition had increased significantly when counting states that were providing logistical and engineering support ${ }^{14}$ OEF was officially terminated in December 2014, marking the end of US combat operations in Afghanistan 15

Due to the protracted nature of the US-led OEF and also the concomitant occurrence of the NATO-led ISAF in 2003, this study is limited to a specific scope of the conflict. It starts with the initial US-led invasion and is censored to the end of 2002. ${ }^{16}$ While US-led OEF continued operations well after this time period, it is difficult to argue that force contributions to the 'war on terrorism' starting after this period were indeed aimed at assisting the US, rather than partaking in NATO led operations. Furthermore, it should be the case that any state that indeed participated in the Afghanistan War due to US dependence should have already proceeded to do so within the designated timeframe.17

\footnotetext{
${ }^{14}$ Neumann, Mundey, and Mikolashek, 2013, pp. 3-4, 8.

${ }^{15}$ While the US ended its OEF mission, it did continue to participate in the NATO led Resolute Support mission aimed to "continue training, advising and assisting Afghan security forces." DoD News, 2014

${ }^{16}$ ISAF itself was authorized by the UN to maintain security in Afghanistan earlier in 2001 Resolution 1386 (2001) 2001). NATO took over full responsibility of the operation in 2003(NATO Public Diplomacy Division, 2006 p. 23).

${ }^{17}$ The study should be able to account for any contributions that started after this period, according to the theory, by those aimed towards the Iraq War that started in 2003.
} 


\subsubsection{Iraq War}

The US-led Iraq War, designated Operation Iraqi Freedom(OIF), started in March 2003. While president Bush announced that major combat missions ended on May 1st of that year, OIF itself continued into 2010.18

\subsection{Research Design}

IMC Participation. The dependent variable is a binary indication of whether or not a state participated in an IMC (participate). It is coded positive(1) if a state participated in an ongoing war in a given year. It is coded zero if it did not.

All states present in the international system at the time an IMC is active can be considered to face a choice of participating or not. Exempt from this decision are 1) the main belligerents already involved in a war, 2) states on the opposing side, and 3) states that are formally forbidden from participating in 'external' wars for either constitutional or other reasons.

Participation is not coded by event (i.e., by wars), but annually. This is due to the fact that the decision to participate in a war is not a one time deal. Especially for conflicts spanning multiple years, states can decide to pull their support at any time. This means that for states that are already participating in a war, they have the option of continuing their participation or withdrawing. This is possible because the war itself does not seem to be of essential interest to them; they are not the initial belligerents, and hence their survival or some other vital national interest is not at immediate risk. In other words, they could simply pack up their bags and leave. On the other hand, states that have not joined an IMC yet may need to re-evaluate their positions continuously. As the IMC continues, they

\footnotetext{
${ }^{18}$ Torreon, 2015. pp. 8-9, US military involvement continued into the end of 2011 under a new name, Operation New Dawn.
} 
need to decide whether or not they will lend support to the effort. For instance, in the Vietnam War, while the conflict itself lasted until 1975, the US pulled out in 1973, and Australia a year earlier in 1972.

The decision to count participation annually does not bias the results towards more positive outcomes. While it does count more cases of participation, negative observations are also being increased by the same factor. Furthermore, it depicts the data more accurately due to late joiners and early deserters. These are states that decide to participate later on in a specific conflict, or leave early. If we were to count participation by conflict, and not years, a state that participated for only a year in a ten year conflict would be considered as having the same level of contribution as another state that participated for all ten. For example, roughly half of the coalition combat forces in the Korean War joined the US immediately in 1950, while the other half joined in 1951.19

The argument for dependence leading to IMC participation is focused on the relationship between a state and an IMC leader (i.e., the US). Therefore, only the years in which the US is involved in a conflict is considered. For instance, although the US pulled its troops from the Vietnam War in 1973, the war itself persisted until 1975. Only the years from 1965 to 1973 are observed as 'coalition participation' in the data, as opposed to coding additional years that states continued to fight in a war where the US was not present. Conceptually, this is also correct since the dependent variable(DV) relevant to the theory is not war participation per se, but IMC participation.

While the MID dataset provides pre-existing coding regarding war participants in inter-state wars, the criteria used in their coding is restrictive and does not reflect the argument of the theory as accurately as it could ${ }^{20}$ The CoW project

\footnotetext{
${ }^{19}$ as coded by the CoW data; 1950: US, Canada, UK, Turkey, Philippines, Australia; 1951: Colombia, Netherlands, Belgium, France, Greece, Ethiopia, Thailand

${ }^{20} \mathrm{CoW}$, Inter-State War Data
} 
sets a qualification standard where a state has to either 1) sustain a minimum of one-hundred fatalities or 2) have one-thousand armed personnel engaged in combat in order to be considered as having participated in a war ${ }^{21}$ The restrictive nature of how the CoW project counts a state as a participant causes a problem of overlooking several states that indeed participated to some extent. Such states are excluded because they do not meet the standards of inclusion.

Considering the fact that states differ in their respective military capabilities and sizes, the standard can be seen to be somewhat arbitrary. For example, it is hard to consider a state sending 100 troops from a standing military of 1,000, to have contributed to a lesser degree than a state that sent 1,000 troops from 15,000 . This conservative approach may not be an inherent problem for some applications, but poses a problem for the analysis intended here.

Therefore, for the purposes of this analysis, states' participation in the six cases that comprise the scope of this study were researched and coded to create an original dataset of IMC participation. To the extent of the author's knowledge, there are currently no readily available datasets that have compiled this information comprehensively. A minimum of three resources were utilized for each event 22

Only states that had troops/forces directly involved in the main theater of operations, either as combatant forces or support units, were considered as participants. This requirement disqualifies forces that were 'contributed' to the Korean War via logistical support to and from Japan, and those that provided indirect military support to the Afghanistan War ${ }^{23}$ Indirect support such as the

\footnotetext{
${ }^{21}$ Refer to [Codebook] The COW Typology of War: Defining and Categorizing Wars (Version 4 of the Data), p. 3.

${ }^{22}$ The relevant sources are listed in Appendix $B$

${ }^{23}$ such as forces committed to the Horn of Africa, and those stationed in Turkey
} 
provision of basing rights, or allowing the use of airspace to coalition forces, are not considered as forms of coalition participation.

In contrast to the CoW criteria, the data coded here has no minimum battle death or troop contribution requirements. Furthermore, it does not restrict the observations to states that have 'armed personnel engaged in combat.' This means that deploying military forces with the primary focus of support, and not combat, is also considered as IMC participation. These include medical units, civil engineering units, logistical assets (cargo aircraft, cargo ships) etc. Such forces, while not primarily intended for combat, still evidence a sign of willingness and commitment to an IMC effort that is higher than no participation at all since such units are nevertheless prone to be exposed to hostilities.

Tables 3.1 and 3.2 provide an overview of the participants in each of the events, as coded by the author, that comprise the scope of this analysis. The participants are listed by each event, and according to their status as an IMC participant, opposition, or as a subject that was receiving the support of an IMC. States that are also coded in the CoW data as being on the same side as the US are indicated in bold for comparison. The immediate difference one will notice is that the subject of initial hostilities are not coded as IMC participants, but as subjects of an IMC. This means that states such as South Korea in the Korean War, and Kuwait in the Gulf War are not considered to be IMC participants. While such states were indeed on the same side as the US, this was not necessarily because they made a conscious decision to participate in the war. On the contrary, they were the subjects that their respective IMCs were aiming to aid.

Regarding the Vietnam War, Cambodia and Laos are not considered to be participants on the US' side. Therefore, no coding was performed. ${ }^{24}$ Although the

\footnotetext{
${ }^{24}$ Laos is coded as a Target/Opponent starting in 1968, and dropped from the possible pool of participants. Cambodia is coded as a non-participant.
} 
MID dataset codes them as being on the same side as the US during the Vietnam War (Phase 2), Communist Coalition, and/or Second Laotian War (Phase 2), the historical accounts demonstrate a more complex relationship where Laos should be considered more as a target, rather than a participant.

\subsubsection{Dependence and IMC Participation}

Economic Dependence. In accordance with hypothesis H1, economic dependence is operationalized through the amount of trade a state conducts with the US. It is assumed that states are sensitive to their trade and want it to be stable at the least, and increased if possible. Under such conditions, if a state (i.e., the protégé) relies on another (i.e., the patron) disproportionately for its trade, it is an indication that it is economically dependent. ${ }^{25}$

The trade variable(trade(log)) hence refers to the annual amount a state exports and imports to and from the US, logged to a base of two ${ }^{26}$ This means that when understanding the results, a one-unit increase in trade(log) refers to a state having double the trade amount (with the US) of another. The expectation is that when the US leads an IMC, more trade dependent states (states that have more trade with the US) are more likely to participate 27

Ideally, differentiating between different types and values of trade would provide even more nuance to the analysis. For instance, even with the same monetary value of imports from the US, one country may rely on it more than another. In short, the contents of the exports, and/or imports, may matter quite significantly. We cannot assume that a state primarily importing convenience

\footnotetext{
${ }^{25}$ Lake (2009, pp. 74-5) refers to this as 'trade dependence', and uses it as an indication of economic hierarchy.

${ }^{26}$ Trade data from the Correlate of War(CoW) Project's Bilateral Trade Data, Version 3.0(CoW, Dyadic Trade Dataset).

${ }^{27}$ The distribution of the logged trade measure, at the start year of each war, is provided in Appendix B
} 
Table 3.1

Military Coalitions and Participants(1)

\begin{tabular}{|c|c|c|c|}
\hline War & Korean & Vietnam & Gulf \\
\hline Coalition & $\begin{array}{l}\text { Australia } \\
\text { Belgium } \\
\text { Canada } \\
\text { Colombia } \\
\text { Denmark } \\
\text { Ethiopia } \\
\text { France } \\
\text { Greece } \\
\text { India } \\
\text { Italy } \\
\text { Luxembourg } \\
\text { Netherlands } \\
\text { New Zealand } \\
\text { Norway } \\
\text { Philippines } \\
\text { South Africa } \\
\text { Sweden } \\
\text { Thailand } \\
\text { Turkey } \\
\text { UK }\end{array}$ & $\begin{array}{l}\text { Australia } \\
\text { New Zealand } \\
\text { Philippines } \\
\text { Republic of China } \\
\text { South Korea } \\
\text { Spain } \\
\text { Thailand } \\
\text { (Cambodia)* }^{\text {Cambon }}\end{array}$ & $\begin{array}{l}\text { Argentina } \\
\text { Australia } \\
\text { Bahrain } \\
\text { Bangladesh } \\
\text { Belgium } \\
\text { Canada } \\
\text { Czechoslovakia } \\
\text { Denmark } \\
\text { Egypt } \\
\text { France } \\
\text { Greece } \\
\text { Honduras } \\
\text { Hungary } \\
\text { Italy } \\
\text { Morocco } \\
\text { Netherlands } \\
\text { New Zealand } \\
\text { Niger } \\
\text { Norway } \\
\text { Oman } \\
\text { Pakistan } \\
\text { Poland } \\
\text { Qatar } \\
\text { Saudi Arabia } \\
\text { Senegal } \\
\text { South Korea } \\
\text { Spain } \\
\text { Syria } \\
\text { Turkey } \\
\text { UAE } \\
\text { UK }\end{array}$ \\
\hline Opposition & $\begin{array}{l}\text { China } \\
\text { N.Korea }\end{array}$ & Vietnam & Iraq \\
\hline Subject & S.Korea & $\begin{array}{l}\text { S.Vietnam } \\
\text { Laos* }^{*}\end{array}$ & Kuwait \\
\hline
\end{tabular}

Coalition states excluding the US

States also coded in CoW data as participants in bold

States coded as participant in CoW data, but not in this data, in parentheses

${ }^{*}$ Laos and (Cambodia) listed as participants on US side in CoW data. 
Table 3.2

Military Coalitions and Participants(2)

\begin{tabular}{|c|c|c|c|}
\hline War & Kosovo & Afghanistan & Iraq \\
\hline Coalition & $\begin{array}{l}\text { Belgium } \\
\text { Canada } \\
\text { Czech Republic } \\
\text { Denmark } \\
\text { France } \\
\text { Germany } \\
\text { Greece } \\
\text { Hungary } \\
\text { Iceland } \\
\text { Italy } \\
\text { Luxembourg } \\
\text { Netherlands } \\
\text { Norway } \\
\text { Poland } \\
\text { Portugal } \\
\text { Spain } \\
\text { Turkey } \\
\text { UK }\end{array}$ & $\begin{array}{l}\text { Albania } \\
\text { Australia } \\
\text { Azerbaijan } \\
\text { Canada } \\
\text { Denmark } \\
\text { Estonia } \\
\text { Finland } \\
\text { France } \\
\text { Germany } \\
\text { Greece } \\
\text { Italy } \\
\text { Lithuania } \\
\text { Netherlands } \\
\text { Poland } \\
\text { Portugal } \\
\text { Romania } \\
\text { Russia } \\
\text { South Korea } \\
\text { Spain } \\
\text { Sweden } \\
\text { Thailand } \\
\text { Turkey } \\
\text { UK }\end{array}$ & $\begin{array}{l}\text { Albania } \\
\text { Armenia } \\
\text { Australia } \\
\text { Azerbaijan } \\
\text { Bosnia and Herzegovina } \\
\text { Bulgaria } \\
\text { Czech Republic } \\
\text { Denmark } \\
\text { Dominican Republic } \\
\text { El Salvador } \\
\text { Estonia } \\
\text { Georgia } \\
\text { Honduras } \\
\text { Hungary } \\
\text { Italy } \\
\text { Japan } \\
\text { Kazakhstan } \\
\text { Latvia } \\
\text { Lithuania } \\
\text { Macedonia } \\
\text { Moldova } \\
\text { Mongolia } \\
\text { Netherlands } \\
\text { New Zealand } \\
\text { Nicaragua } \\
\text { Norway } \\
\text { Philippines } \\
\text { Poland } \\
\text { Portugal } \\
\text { Romania } \\
\text { Slovakia } \\
\text { South Korea } \\
\text { Spain } \\
\text { Thailand } \\
\text { Tonga } \\
\text { UK } \\
\text { Ukraine }\end{array}$ \\
\hline
\end{tabular}

\begin{tabular}{clll}
\hline Opposition & Yugoslavia & Afghanistan & Iraq \\
\hline Subject & - & - & - \\
\hline
\end{tabular}


and luxury goods from the US will value its imports as much as would another state that primarily imports some vital natural resource or essential good.

The ability to make these differentiations would also take us a long way towards gaining more insight into how important the availability of alternative patrons and/or exit costs are for the theory. However, the problem is that what may seem essential or vital to one country may not be so for another. The substantive nature of parsing out what resource is to be weighted for each patron and protégé among their exports and imports is prohibitive.

In order to address this issue partially, I employ a control for a country's status as an oil exporter ${ }^{28}$ Oil is one resource that the US has maintained a strategic interest in during the scope of the analysis. It can also be consistently applied both spatially and temporally. The variable, oil exporter, is a dummy that is coded positive for states that are primarily exporters of oil.

Security Dependence. In accordance with hypotheses H2 and H3, security dependence is operationalized through alliance commitments and the number of deployed US troops.

The first measure, alliance commitments, is a binary measure that codes states as either receiving a defensive alliance commitment from the US or not (ally) ${ }^{29}$ While the measure is highly related to alliances in general, the direction of the commitment is important in evaluating the theory.

The argument expects states to participate in US-led IMCs in order to guarantee the US honoring its own commitment to them in the future. It is not a statement that states will view a US-led IMC as a defensive situation where it will honor its own commitment to the US. In other words, the analysis is not one of evaluating the reliability of an alliance agreement, but one of how a state will

\footnotetext{
${ }^{28}$ Eichengreen and Leblang, 2008, pp. 303-4.

${ }^{29}$ From CoW, Formal Alliances Dataset
} 
go out of its way to enhance the reliability of another's agreement to itself into the future.

The second mode of security dependence is the routine and semi-permanent deployment of US troops to a state. ${ }^{30}$ Higher numbers of troops may evidence a higher strategic interest on the patron's part, but also indicates that the protégé is willing to allow the stationing of such troops. It also shows that the protégé needs the higher numbers to ensure its continued security.

Whether it is the stationing of US troops in South Korea to deter North Korean hostilities, or in West Germany to keep the Soviet Union at bay before its collapse, not only did the US have (and still has) its own strategic interests in the respective regions, but both Korea and Germany also relied on the extended deterrence.

For the analysis, this idea of stationed troops is operationalized by taking the number of US troops deployed within a country by the tens of thousands $(u s$ troops). This is to account for the fact that a typical US army division stands somewhere between ten to eighteen thousand troops ${ }^{31}$ This means that when understanding the results, we can roughly approximate any effect as that of having one more, or less, division of US troops on one's soil.

Summary Statistics of Independent Variables. Table 3.3 provides an initial overview of the dependence related variables. All of the presented statistics are means by participant status, with the exception of the alliance measure. This

\footnotetext{
${ }^{30}$ Original data compiled and provided by the Heritage Foundation. See Kane, Global US Troops Deployments. The data uses original reports provided by the US Department of Defense and compiles comprehensive time series data by year and country. While the report cites the Statistical Information Analysis Division(SIAD) of the Directorate for Information Operations and Reports(DIOR) within the DoD as its source, the original source of data has apparently been moved to the Defense Manpower Data Center(DMDC). Their publications were last accessible by the author (as of December, 2015) at www.dmdc.osd.mil/appj/dwp/reports.do?category= reports\&subCat $=$ pubs

${ }^{31}$ http://www . army . mil/info/organization/unitsandcommands/oud/
} 
is the portion of states in each group that were receiving a defensive alliance commitment from the US (ally).

Table 3.3

Summary Statistics: all cases(IVs)

\begin{tabular}{lccc}
\hline & trade(log) & ally & us troops \\
\hline \hline & & & \\
Non Participants & 26.87 & 0.29 & 0.08 \\
& $(3.39)$ & & $(0.59)$ \\
& & & \\
Participants & 30.03 & 0.66 & 0.78 \\
& $(2.85)$ & & $(1.49)$ \\
& & & \\
\hline standard deviations in parentheses & &
\end{tabular}

The nascent comparison shows a consistently higher mean for participant states on all measures. For the ally variable, it shows that a larger portion of participant states had some form of defense alliance commitment from the US than non-participant states.

In static comparison, states receiving defensive commitments from the US participated in US-led IMCs to a larger degree than those that were not receiving such a commitment. Sixty-six percent of participants had a formal military alliance commitment from the US. These were alliances in which they were the recipient of a defensive commitment from the US. In comparison, more than seventy percent of states that did not contribute to US-led IMCs were those that were not receiving such commitments. 


\subsubsection{Balance of Threat, Opportunity/Willingness, and IMC Par- ticipation}

Distance to Conflict In accordance with hypothesis BoT-H1, distance is operationalized by taking the distance between two states' capitals, in thousands of kilometers(distance) ${ }^{32}$ The two capitals in this instance are for that of a state in question, and that of which an IMC is primarily operating within. For example, for the years of the Korean War, it would be the distance from a particular state's capital to that of North Korea, and for the Vietnam War it would be to that of North Vietnam. The expectations for both Balance of Threat and $\mathrm{O} / \mathrm{W}$ are that an increase in distance will be associated with a decrease in a state's probability of being involved in an IMC.

The idea of distance between states can be measured through various means. It can be the distance between two capital cities, the closest distance between borders, etc. The distance between capital cities are used in consideration of the fact that states may feel differing levels of threat from different borders. While borders and contiguity are typically used in many analyses, states may evaluate conflicts closer to certain borders as more threatening than others.

Considering the locations of the capitals of Russia, China, or even the US, it is noticeable that they are skewed to one side of the overall territory of that state. It cannot be assumed that Russia would feel the same level of threat from a conflict near its eastern border as it would to one on its western one, where the majority of its major cities and capital are at.

\section{Aggregate/Material Power(Target, Participant) Both BOT-H2 and OW-H1 are} related to the power of states. The former regards that of the target of an IMC,

\footnotetext{
${ }^{32}$ The capital distances are derived with the C-Shapes package in R. Refer to Weidmann, Kuse, and Gleditsch (2010).
} 
and the latter that of states that consider participation. The power of a state is operationalized through CINC scores from the CoW project ${ }^{33}$ The Composite Index of National Capability(CINC) scores consider six elements of material capability: 1) total population, 2) urban population, 3) military personnel, 4) military expenditures, 5) primary energy consumption, and 6) iron and steel production. The index is a measure of how much of the total in the international system a state's share is. For instance, a CINC score of .2 for state $x$ in the year $t$ means that from all the material capabilities prevalent in the international system in the year $t$, state $x^{\prime}$ s share was .2, or 20 percent. The scores, originally coded on a scale from 0 to 1 in the NMC dataset, are recoded to percentage points (scale of 0 to 100) for this analysis.

The aggregate power of a target is one of the two cornerstones of Walt's argument. Along with geographic proximity, the aggregate power of a neighboring state is the main source of how states assess threat ${ }^{34}$ The variable power(target) hence refers to the converted CINC scores of the main target of an IMC. For instance, it is that of North Korea in the Korean War, and Iraq in the Gulf War.

On the other hand, according to Joyce, Ghosn, and Bayer, the material power of a state(potential joiner) determines its level of opportunity. In other words, a state's capability dictates whether or not it can participate in a war. Subsequently, the variable power refers to the converted CINC scores of a state. The expectations for both Balance of Threat and $\mathrm{O} / \mathrm{W}$ are that an increase in either of these measures will be associated with an increase in a state's probability of being involved in an IMC.

Regime Type(Leader, Subject) Both BOT-H3 and OW-H2 consider the regime type of states. The regime type of a state is measured with the Polity2 scores

\footnotetext{
${ }^{33} \mathrm{CoW}$, National Material Capabilities version 4.0

${ }^{34}$ Walt, 1987
} 
provided in the Polity IV project. ${ }^{35}$ The Polity2 scores are a measure of a state's democracy/autocracy level, and are coded on a twenty-one point scale ranging from negative(more autocratic) to positive ten(more democratic).

Walt expects regime type to have no substantial effect on alliance formation. The variable regime distance(us) is the absolute values of how far a state's regime type is from the US. The expectation is that increases in the measure (states are farther from the US' regime type, or has less affinity with the US), will not have a substantive effect on IMC participation (alliance formation).

Joyce, Ghosn, and Bayer's triadic approach to war diffusion rather focuses on the regime distance between a state and the subject of an IMC. This moves the focus from an IMC leader to that of an IMC subject, and regime distance(subject) accordingly refers to the absolute values of how far a state's regime type is from that of an IMC subject.

For instance, it is the regime distance between a state and South Vietnam in the Vietnam War period, and that of a state and Kuwait during the Gulf War. For cases where there is no immediate subject (i.e., Afghanistan and Iraq), it is measured from the regime type of the US. As for the Kosovo Air Campaign, it is measured from that of Albania 36

The expectation, according to the Opportunity/Willingness framework, is that increases in regime distance will lead to a decrease in the likelihood that a state will assist another state that is in trouble (participate in an IMC).

Alliance with Subject Finally, in accordance with OW-H3, ally(subject), is a binary indication of if a state had a defensive alliance commitment towards the subject of an IMC. The expectation is that states will honor their defensive

\footnotetext{
${ }^{35}$ Polity IV Annual Time Series, Version 2013

${ }^{36}$ The focus and cause of the Kosovo Air Campaign was that Milosevic was targeting ethnic Kosovar-Albanians.
} 
commitments and participate in an IMC to support a state in war. The subjects of an IMC are identical to that of regime distance(subject), and states' alliances are in reference to those states.

Summary Statistics of BoT and O/W Variables. Table 3.4 provides an initial overview of the variables related to the Balance of Threat and Opportunity/Willingness arguments. All of the presented statistics are means by participant status, with the exception to the alliance measure. This is the portion of states in each group that have a defensive alliance commitment to the subject of an IMC. Table 3.5 provides an overview of the converted CINC scores of the targets of IMCs. The right most column in this table are the mean values of the measure for all states in the system for comparison.

Table 3.4

Summary Statistics: all cases(BoT and $\mathrm{O} / \mathrm{W})$

\begin{tabular}{lccccc}
\hline & distance & power & $\begin{array}{c}\text { regime } \\
\text { distance(us) }\end{array}$ & $\begin{array}{c}\text { regime } \\
\text { distance(s*) }\end{array}$ & $\begin{array}{c}\text { ally } \\
\left(\mathbf{s}^{*}\right)\end{array}$ \\
\hline \hline \multirow{2}{*}{ Non Participants } & 9.04 & 0.52 & 10.98 & 6.99 & 0.04 \\
& $(4.63)$ & $(1.82)$ & $(7.24)$ & $(5.47)$ & \\
Participants & 5.85 & 0.85 & 4.66 & 7.83 & 0.15 \\
& $(3.79)$ & $(1.11)$ & $(6.71)$ & $(6.39)$ & \\
& & & & & \\
\hline
\end{tabular}

standard deviations in parentheses

$s^{*}$ : subject

The initial comparison of participant and non-participant states evidence support for some of the arguments made by Walt and Joyce, Ghosn, and Bayer. Participant states are on average closer to a conflict, and have more material power. The portion of states that had an alliance commitment towards a subject is approximately three times higher for participant states. As for regime type, the 
Table 3.5

Summary Statistics: Power of Target

\begin{tabular}{lcc}
\hline & $\begin{array}{c}\text { Power } \\
\text { of target }\end{array}$ & $\begin{array}{c}\text { Power } \\
\text { mean, all states }\end{array}$ \\
\hline \hline N.Korea('50-'53) & 0.29 & 0.92 \\
& $(0.05)$ & $(2.42)$ \\
N.Vietnam('65-'73) & 0.49 & 0.61 \\
& $(0.07)$ & $(1.87)$ \\
Iraq('91) & 0.83 & 0.50 \\
& $(0.00)$ & $(1.35)$ \\
Yugoslavia('99) & 0.20 & 0.45 \\
& $(0.00)$ & $(1.37)$ \\
Afghanistan('01) & 0.12 & 0.45 \\
& $(0.00)$ & $(1.41)$ \\
Iraq('03) & 0.66 & 0.45 \\
& $(0.00)$ & $(1.45)$ \\
\hline standard deviations in parentheses &
\end{tabular}

nascent comparison shows that, on average, non-participant states were farther from the US' regime type, but actually closer to that of a subject. 


\subsection{Methodology.}

The data is compiled in panel format, where rows contain a single-year observation of a state. For each year, the variable war is added. This is a non-ordered categorical variable that indicates if there was an IMC present in that year, and if so, which war it was of the six that comprise the cases of this analysis.

Wars are coded from 0 (not a war year) to 6 (the Iraq War), in chronological order. These conflict level fixed effects are included in all models to remove changes in the effect of any of the $x$ variables in the model from conflict to conflict, and to account for participation in different wars over time. This prevents comparing state $a$ against itself in one war and another. Without these fixed effects, the result would be a pooling of all the observations into one. This would result in a very misleading analysis, that would effectively be comparing apples to oranges. For instance, without the war level fixed effects, the effect of Colombia having an alliance with the US when facing the Korean War would be compared to the UK having one in Afghanistan, and so on.

Therefore, all of the results can be understood as a between-effect of each of the variables for the countries. In other words, it is not the case that a one unit increase in $x$ will lead to a change in a state's probability of IMC participation in the next conflict. The effect of a one unit increase in $x$ rather means that a state that is higher on $x$ is more likely (or, less likely) to participate in a conflict when compared to another state that is lower on $x$.

Running separate analyses for each war would in theory enable us to not only see if effects for certain variables are present in some wars and not in others, but also see if those effects changed throughout different wars. However, the limited number of observations makes this approach prohibitive. 
Four separate logit regressions are done on the years where a war was present, using the 'logistic' command in STATA 12.1. ${ }^{37}$ This estimates how changes in each factor increase, or decrease, the likelihood of IMC participation. The inclusion of multiple wars does not inherently bias the results, but it should be understood that the resulting estimates that are derived are averaged effects across all wars.

States that were the subject of an IMC (e.g., Kuwait in the Gulf War), states on the opposing side of an IMC (e.g., Yugoslavia in Kosovo), and those that have constitutional restrictions on the deployment of their military abroad (i.e., Japan) are excluded from the pool of possible participant states.

The first model tests the Balance of Threat argument, with the relevant variables distance, regime distance(us), and power(target). While Walt does not specify that the power of a state itself is also relevant, I believe that the level of threat is relative, and not absolute. Therefore, the analysis also controls for a state's own power(power).

The second model tests the Opportunity/Willingness argument, with the relevant variables distance, power, regime distance(subject), and ally(subject). The 'competing risks' aspect of the original hazard models employed by Joyce, Ghosn, and Bayer do not pose a significant problem, since states that were on the opposing side of an IMC are removed from the possible pool of participants in the model deployed here.

The third and fourth models test the dependence arguments. Each model tests the economic dependence and security related dependence arguments separately, respectively using the trade, or troops and alliance measures. A

\footnotetext{
${ }^{37}$ war $\neq 0$
} 
fifth model including all of the dependence measures is also presented ${ }^{38}$ These models also control for distance, regime distance to the US, and power.

\subsection{Results}

The results of the logit regressions are displayed in Table 3.6. The table provides odds ratios and standard errors in parentheses. Statistical significance is expressed at the $p<0.05$ level. Results for each conflict and the constant are not included ${ }^{39}$ Additional results for alternate specifications of the model(s) are provided in Appendix B these include using the CoW war participation data instead of the original IMC participation dependent variable, and using just one count of war participation (at the start year of a conflict) as opposed to counting participation annually. Changes in the model specifications do not have any adverse effects on the results.

The distance between a state and a conflict is consistently significant throughout all models and the results show that, all else equal, states are less likely to participate in conflicts that are farther away from themselves. Regime distance to an IMC leader also finds consistent support, and shows that regime type does have a substantive effect, conflicting with the assertion by Walt that 'birds of a feather' do not flock together(BOT-H3).

Regime distance also finds support in the Opportunity/Willingness model, but in the opposite direction than anticipated. Model (2) shows that states that are farther from a subject's regime type are actually more likely to support it

\footnotetext{
${ }^{38}$ The fifth model including all of the dependence measures together is included in the results for comparative purposes. The statistical significance and substantive direction of the effects are identical.

${ }^{39}$ Results including the fixed effects at the conflict level and the constants are provided in Table B.3 in Appendix B Table B.4 in the same appendix provides the same results with coefficients, rather than odds ratios.
} 
Table 3.6

Logit Results: Odds Ratios

\begin{tabular}{|c|c|c|c|c|c|}
\hline & $(1)$ & $(2)$ & (3) & $(4)$ & (5) \\
\hline trade(log) & & & $\begin{array}{l}1.525^{*} \\
(0.062)\end{array}$ & & $\begin{array}{l}1.294^{*} \\
(0.061)\end{array}$ \\
\hline ally & & & & $\begin{array}{l}11.397^{*} \\
(2.798)\end{array}$ & $\begin{array}{l}6.893^{*} \\
(1.750)\end{array}$ \\
\hline us troops & & & & $\begin{array}{l}2.440 * \\
(0.370)\end{array}$ & $\begin{array}{l}2.117^{*} \\
(0.325)\end{array}$ \\
\hline distance & $\begin{array}{l}0.788^{*} \\
(0.019)\end{array}$ & $\begin{array}{l}0.843^{*} \\
(0.022)\end{array}$ & $\begin{array}{l}0.741^{*} \\
(0.019)\end{array}$ & $\begin{array}{l}0.709^{*} \\
(0.022)\end{array}$ & $\begin{array}{l}0.700^{*} \\
(0.022)\end{array}$ \\
\hline regime distance(us) & $\begin{array}{l}0.869^{*} \\
(0.011)\end{array}$ & & $\begin{array}{c}0.945^{*} \\
(0.013)\end{array}$ & $\begin{array}{l}0.920^{*} \\
(0.014)\end{array}$ & $\begin{array}{c}0.950^{*} \\
(0.015)\end{array}$ \\
\hline power(target) & $\begin{array}{c}3.426 \\
(6.144)\end{array}$ & & & & \\
\hline power & $\begin{array}{c}1.037 \\
(0.043)\end{array}$ & $\begin{array}{c}1.063 \\
(0.043)\end{array}$ & $\begin{array}{l}0.780^{*} \\
(0.058)\end{array}$ & $\begin{array}{c}0.936 \\
(0.071)\end{array}$ & $\begin{array}{l}0.763^{*} \\
(0.079)\end{array}$ \\
\hline regime distance(subject) & & $\begin{array}{l}1.063^{*} \\
(0.018)\end{array}$ & & & \\
\hline ally(subject) & & $\begin{array}{l}10.749 * \\
(3.657)\end{array}$ & & & \\
\hline oil exporter & & & $\begin{array}{l}0.175^{*} \\
(0.089)\end{array}$ & $\begin{array}{c}0.497 \\
(0.248)\end{array}$ & $\begin{array}{c}0.282^{*} \\
(0.147)\end{array}$ \\
\hline Observations & 1,999 & 1,024 & 1,904 & 1,842 & 1,788 \\
\hline
\end{tabular}


in war ${ }^{40}$ The consistent support found in the expected direction for the other measure of regime distance with the US (even in models 3 through 5 where it is intended only as a control) is theoretically more convincing: states with a lesser affinity with an IMC leader concerning regime type are less likely to support it in war. The point also lends further support to my argument that we need to focus on states' relationship with an IMC leader, rather than the subjects of such IMCs.

Aggregate or material power does not prove to be significant in either the Balance of Threat model (power of a target), or the Opportunity/Willingness model (power of a state). While the odds ratios point in the expected direction in model (1), the standard errors are too large and preclude the possibility of making any definitive statements regarding its impact on threat assessment and war participation. The high impact of distance, rather is the only hint that confirms the Balance of Threat mechanism to be working. That a state's material capability defines its 'opportunity' also fails to find support in model (2), and while the effect is in the expected direction, it is substantively fairly small and also statistically insignificant.

Table 3.7 provides a summary of the expectations and results of the analyses for the Balance of Threat and $\mathrm{O} / \mathrm{W}$ models.

In contrast, all of the variables of interest in the dependence models are consistently in their expected directions, and significant. While the odds ratios are interesting in and of themselves, I rather utilize marginal effects to discuss the substantive effects more effectively.

By taking the derivatives $\left(\frac{d P(y=1)}{d x}\right)$, we can more directly discuss what one unit change in any $x$ brings to $P(y=1)$. Table 3.8 displays these marginal

\footnotetext{
${ }^{40}$ Albeit, the substantive effect is quite small.
} 
Table 3.7

Balance of Threat and O/W: Assessment

\begin{tabular}{|c|c|c|c|c|}
\hline & Hyp' & Main Factor & Expect' & Result \\
\hline \multirow{3}{*}{ BoT } & BoT-H1 & Distance to Conflict & - & - \\
\hline & BoT-H2 & Power of Target & + & $x$ \\
\hline & BoT-H3 & Regime Affinity with IMC Leader & $x$ & + \\
\hline \multirow{3}{*}{$\mathrm{O} / \mathrm{W}$} & OW-H1 & Power of Potential Joiner & + & $x$ \\
\hline & $\mathrm{OW}-\mathrm{H} 2$ & Regime Affinity with Subject & + & - \\
\hline & OW-H3 & Alliance Status with Subject & + & + \\
\hline
\end{tabular}

$(+)$ positive association; (-)negative association; $(x)$ no association

effects and their respective $95 \%$ confidence intervals. ${ }^{41}$ The marginal effects for the economic dependence (3) and security related dependence (4) models are presented, respectively. The next section discusses each further. ${ }^{42}$

\footnotetext{
${ }^{41}$ Levels of statistical significance are not displayed with conventional asterisks. However, the reader should be able to discern for themselves fairly easily if the displayed marginal effects are statistically significant by looking at the corresponding confidence interval to see if the effect is discernible from zero.

${ }^{42}$ Table B.5 in Appendix B present the marginal effects for the BoT and O/W models.
} 
Table 3.8

Dependence Models: Marginal Effects

\begin{tabular}{lcc}
\hline & $(3)$ & $(4)$ \\
\hline \hline & 0.030 & \\
trade $(\log )$ & $(0.025 \sim 0.036)$ & \\
ally & & 0.155 \\
& & $(0.128 \sim 0.182)$ \\
us troops & 0.057 \\
& -0.022 & $(0.039 \sim 0.075)$ \\
distance & -0.018 & -0.022 \\
& $(-0.025 \sim-0.019)$ & $(-0.025 \sim-0.019)$ \\
power & $-0.028 \sim-0.008)$ & $(-0.014 \sim 0.004$ \\
& -0.004 & -0.005 \\
regime distance $(\mathrm{us})$ & $(-0.006 \sim-0.002)$ & $(-0.007 \sim-0.003)$ \\
oil exporter & -0.126 & -0.045 \\
& $(-0.197 \sim-0.054)$ & $(-0.107 \sim 0.018)$ \\
& & \\
Observations & 1,904 & 1,842 \\
\hline marginal effects $\left(\frac{d P(y=1)}{d x}\right)$ & \\
95\% confidence intervals in parentheses & \\
marginal effects for war level fixed effects not reported
\end{tabular}

\subsection{Discussion}

Model (3) supports the argument that states more dependent on the US in respect to their trade are more likely to participate in US-led IMCs. The marginal effects of the logged measure of trade with the US in Table 3.8 show that a state that trades double the amount with the US is .03 more likely to participate in a US-led $\mathrm{IMC} 43$

Figure 3.1 illustrates the predicted probabilities of IMC participation, according to trade levels. The $95 \%$ confidence intervals are presented along as the shaded area. It shows that the predicted probability of IMC participation increases with the increase of trade dependence.

\footnotetext{
${ }^{43}$ The trade measure is the log-base- 2 of a state's total trade with the US.
} 
Figure 3.1

Trade: Predictive Margins

with 95\% Confidence Intervals

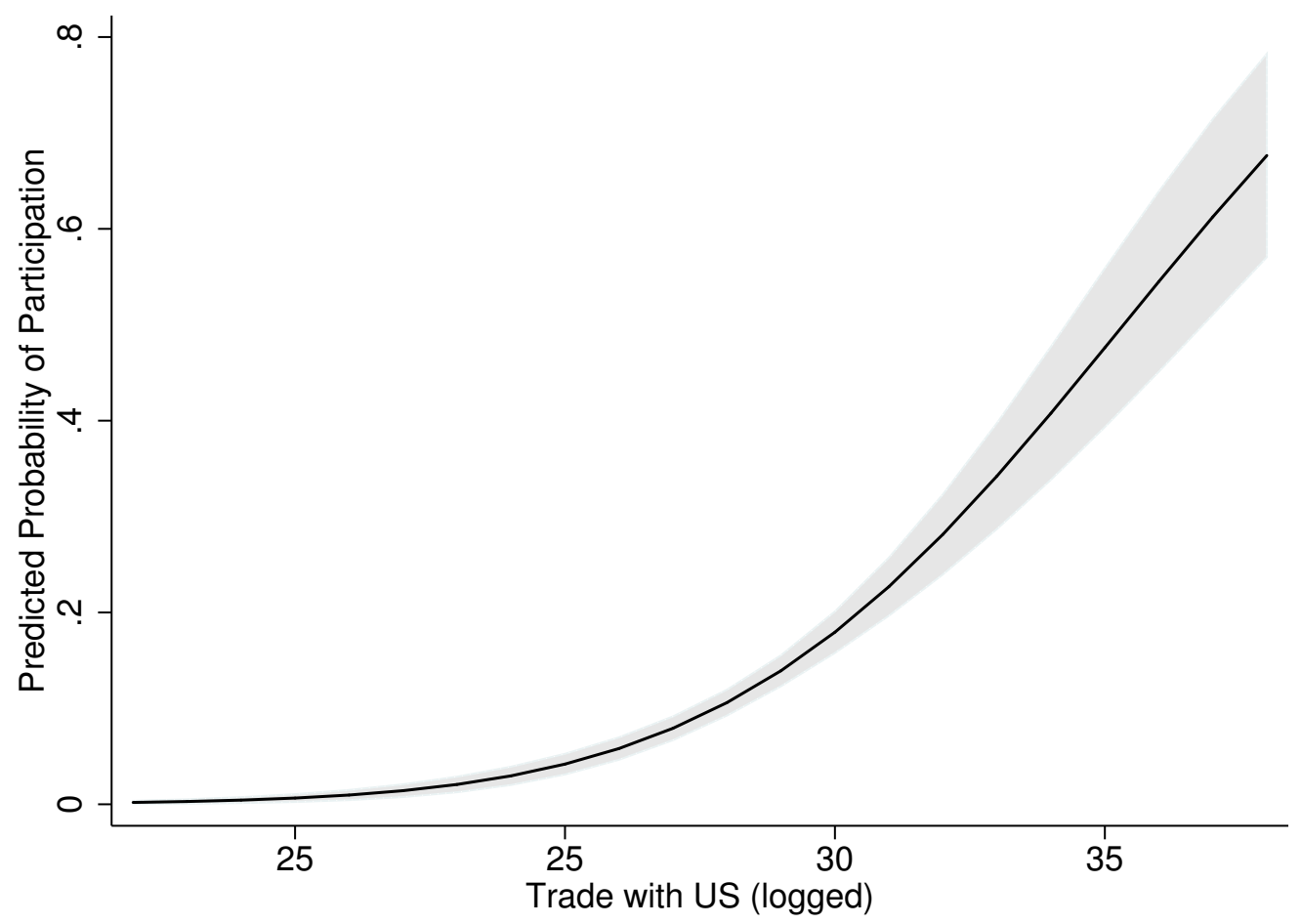

In line with several studies of war diffusion and the general alliance literature, the results of model (4) show that, ceteris paribus, states that have a defensive alliance commitment from the US are more likely to participate in IMCs led by the US.

Figure 3.2 shows the estimated likelihoods of participation according to the presence of such commitments (with their respective 95\% confidence intervals). It shows that, all else equal, states to which the US have a formal obligation to defend are predicted to be much more likely to participate in US-led IMCs elsewhere, than those that do not have such commitments from the US: the former have a predicted likelihood of .266, while the probability of the latter is .069 .

The increase in IMC participation does not have to do with alliance reliability. 
Figure 3.2

Defense Alliance Commitments: Predictive Margins with $95 \%$ Confidence Intervals

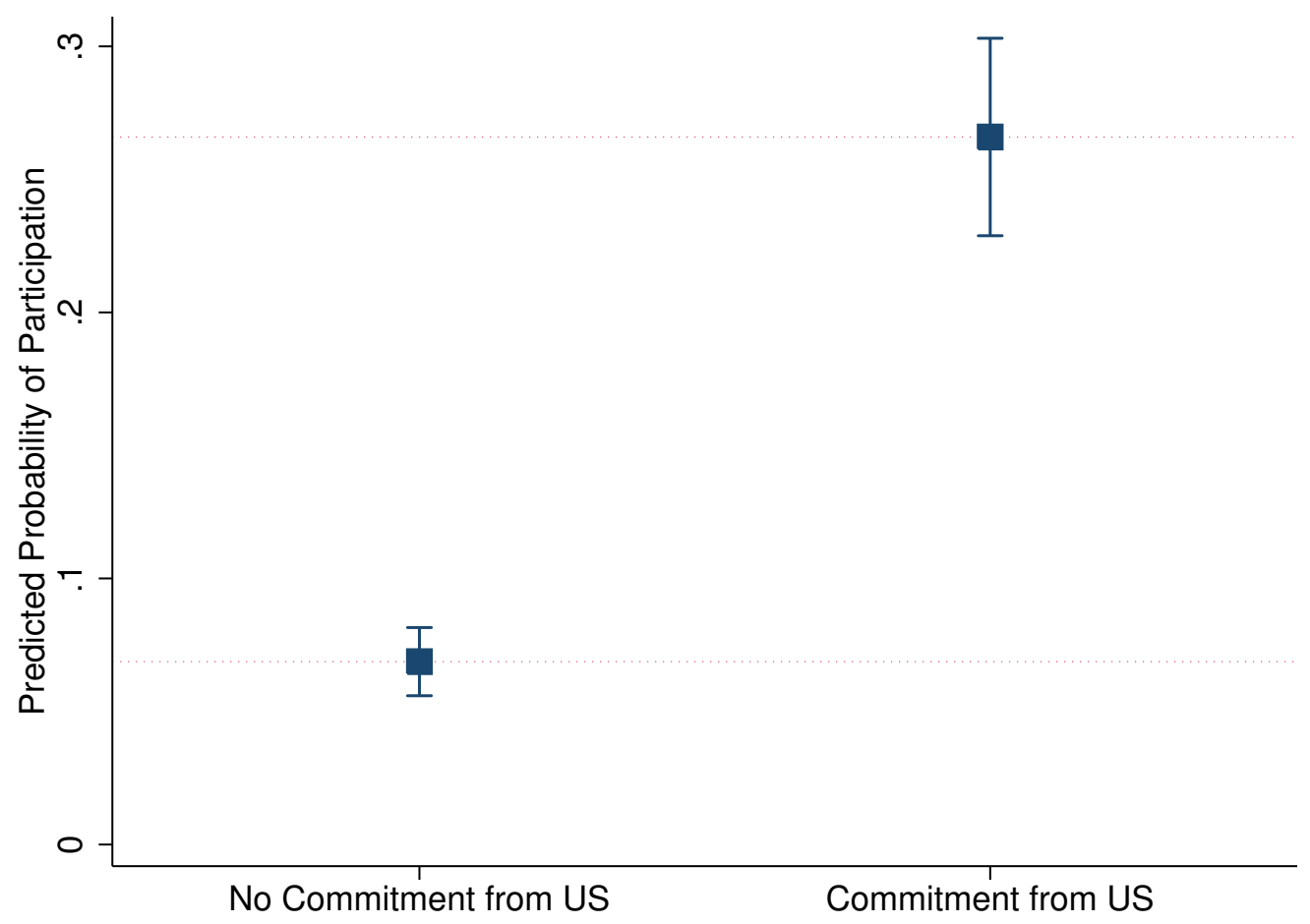

The cases the analysis is concerned with are not wars in which the US is in a defensive situation. Accordingly, the fact that any of these states fought on behalf of the US does not mean it is 'honoring' its alliance commitment. Furthermore, the measure used here is for commitments from the US. This means that the fact that a state was on the receiving end of a commitment from the US led to the results we see here.

The security dependence model also finds a positive correlation between the number of US troops stationed within a state and the probability of that state participating in an IMC led by the US. Figure 3.3 shows that states with 120 thousand US troops, or 12 divisions, and above almost always participate in 
US-led IMCs ${ }^{44}$ In comparison, states without any stationed US troops have an approximate $10 \%$ likelihood of participating in an IMC led by the US.

\section{Figure 3.3}

US Troops: Predictive Margins

with 95\% Confidence Intervals

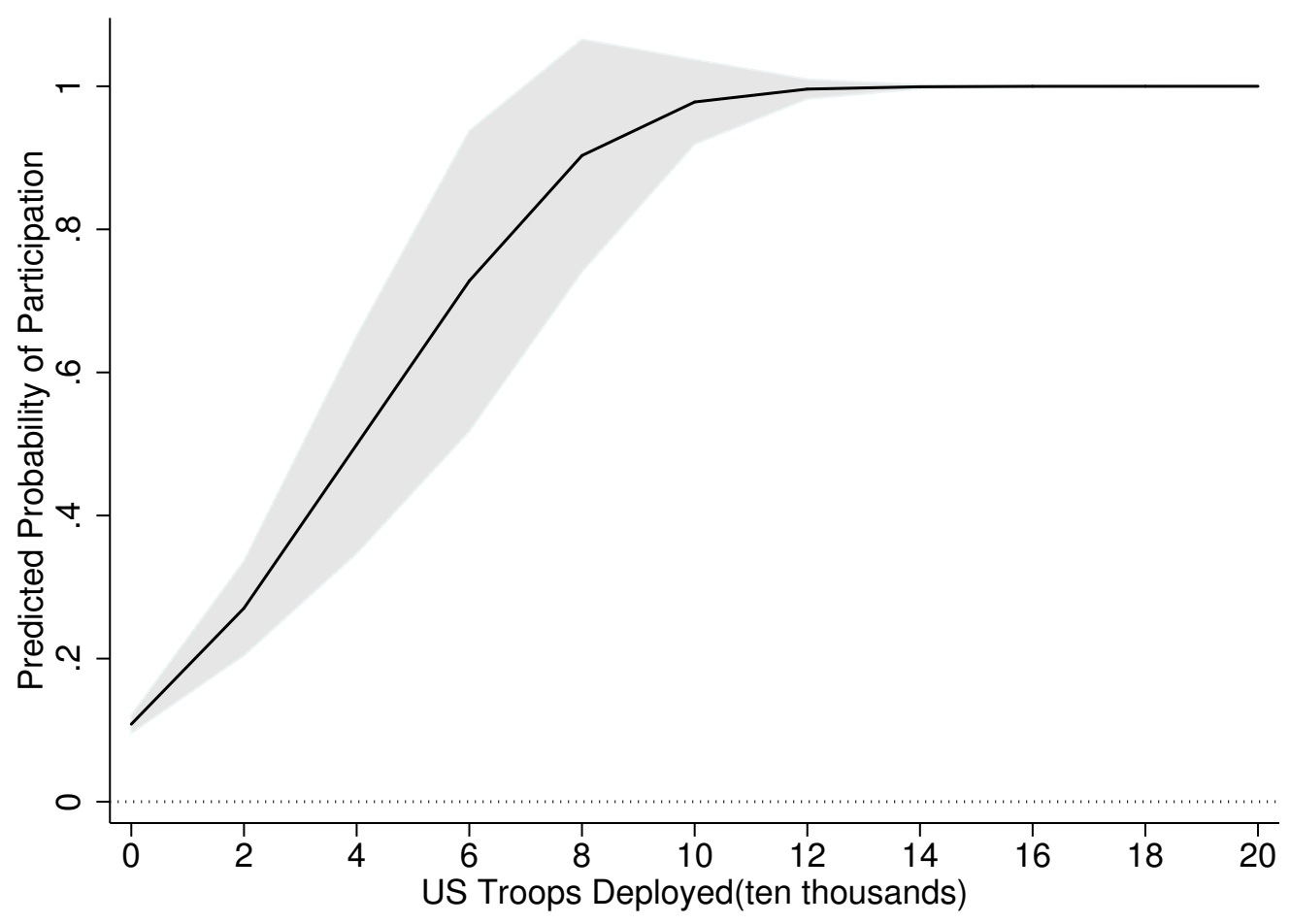

This relationship makes no sense if the presence of US troops on one's own soil is an indication of a state's military weakness and vulnerability. On the contrary, if the stationing of troops was understood as such, we would find the exact opposite effect: states with more stationed troops should show a lower likelihood of participating in some IMC elsewhere. States in need of more US troops would be less likely to sacrifice its own troops to aid the US in some distant war irrelevant to its immediate security.

\footnotetext{
${ }^{44}$ The straight line to the righthand side of the graph is not due to an identification problem: the standard errors are not inestimable, indicating a lack of data, but essentially so small that they are close to zero (e.g., the standard error at 180 thousand troops is .0000514). The last two confidence intervals in Table B.9 have this same problem: the intervals are shown to the sixth decimal point at the bottom of the table to illustrate the point.
} 
However, the results show the exact opposite relationship, where, ceteris paribus, states with more US troops stationed on their ground are more likely to join the US in an IMC elsewhere. Neither is the effect being driven by instances in which the US has deployed troops to a state that is already embroiled in war. The analysis does not count the initial belligerents of a war. Hence, this is not being driven by US troops concentrating in South Korea in the Korean War, South or North Vietnam in the Vietnam War, etc.

\subsection{Conclusion}

Trade, alliance commitments, and stationed troops all find full support for the theory of dependence and IMC participation. The findings are robust to alternate specifications of the model and suggest a substantively significant effect for all of the measures of dependence.

The support found for the expectations laid out by the dependence argument is also more consistent and adds more to our understanding of IMC participation than the other two alternate explanations. Table 3.9 summarizes the expectations and results of the three competing arguments. Only one hypothesis from the Balance of Threat model found support, and one out of three found support for the Opportunity/Willingness model. Moreover, with regards to regime distance, the Opportunity and Willingness argument predicted that being farther from an IMC subject's regime type would reduce the likelihood that a state would participate in war to support it. However, the results show the exact opposite.

All three modes of dependence find support in the dependence model(s), suggesting that focusing on the dyadic relationship between a state and an IMC leader expands our understanding of war diffusion and IMC participation. Furthermore, while the theory itself has no expectations for the effect of distance, 
Table 3.9

Summary of Support for Arguments

\begin{tabular}{|c|c|c|c|c|}
\hline & Hypo' & Main Factor & Expect ${ }^{\prime}$ & Result \\
\hline \multirow{3}{*}{ Dep $^{\prime}$} & H1 & Level of Trade with IMC Leader & + & + \\
\hline & $\mathrm{H} 2$ & Alliance Status with IMC Leader & + & + \\
\hline & $\mathrm{H} 3$ & Level of IMC Leader Troops in Territory & + & + \\
\hline \multirow{3}{*}{ BoT } & BoT-H1 & Distance to Conflict & - & - \\
\hline & BoT-H2 & Power of Target & + & $x$ \\
\hline & BoT-H3 & Regime Affinity with IMC Leader & $x$ & + \\
\hline \multirow{3}{*}{$\mathrm{O} / \mathrm{W}$} & OW-H1 & Power of Potential Joiner & + & $\mathrm{x}$ \\
\hline & $\mathrm{OW}-\mathrm{H} 2$ & Regime Affinity with Subject & + & - \\
\hline & OW-H3 & Alliance Status with Subject & + & + \\
\hline
\end{tabular}

$(+)$ positive association; (-)negative association; $(x)$ no association

or regime types, the results for each of these measures support most of the findings and conventional arguments in the IR literature as well. 


\section{Chapter 4}

\section{Following the US to Vietnam and Korea: Case Studies of South Korea and Brazil}

In this chapter, I explore the mechanisms leading to IMC participation in more detail through two case studies: Brazil in the 1950s, and South Korea in the 1960s. The cases of South Korea and Brazil illustrate that both states negotiated their participation in US-led military endeavors with considerations of US benefits primarily in mind. While the quantitative analyses in the previous chapter demonstrate that states dependent on the US are more likely to offer their support to a US-led military effort, it is not able to actually parse out how high levels of dependence lead to participation. The two cases in this chapter are intended to illustrate that process in more detail. 


\subsection{Introduction}

Figure 2.3 in Chapter 2 identifies two causal mechanisms leading to IMC participation. The first process is IMC participation due to Future Expectations. Participation by a protégé happens when it desires an increase in benefits from a patron, and expects to be rewarded for its IMC participation. The second process leading to participation is driven by the Fear of Abandonment. In this case, a protégé participates in an IMC led by its patron because it 1) expects some form of retribution for non-compliance, 2) understands that there are minimal exit costs for its patron, 3) and sees that there are no alternative patrons available.

These processes are examined through South Korea in the 1960s, and Brazil in the 1950s. The two cases are selected, first for the fact that neither were faced with an immediate security threat from the conflicts themselves due to the geographic distances between their territories and that of the conflicts. Both cases were also during the height of the Cold War, when concerns of the spread of communism were real, often used in rhetoric, and in justifying military behavior.

The decision made by South Korea to participate in the Vietnam War is a controversial subject, with an abundance of debates regarding the political/economical, and moral motivations for its role in the war. The prevalent understanding on either side of this debate though, is that the state was indeed handsomely rewarded for its cooperation by the US, and that the event marked a turning point in the start of its economical success. Furthermore, the geographic distance between the two states of Korea and Vietnam precludes the possibility that the former state participated out of some perception of immediate threat to its security. This makes it an ideal subject of analysis to see if considerations of dependence and benefits led it to participate.

The major factor of geographic distance can also be precluded from the case 
of Brazil and the Korean War. In fact, Brazil did not participate in the Korean War. Therefore, it is ultimately a non-observation when it comes to IMC participation. However, it presents an interesting anomaly because it was one of seven states that initially offered its support but were turned down by the US. ${ }^{1}$ The US JCS and State Department rejected most of these states' offers due to political or military concerns. For instance, it was concerned that Taiwan's involvement would diffuse the conflict into an enlarged war with China, and that the offers of states like Costa Rica and El Salvador were simply too small, and that the costs of arming and training such units outweighed the benefits. ${ }^{2}$

In contrast, its rejection of Brazil was a formality that was more due to the latter state's tediousness in actually providing any substantive forces to follow up its word $]^{3}$ Furthermore, the US approached Brazil as an ideal candidate for sending additional troops to the peninsula in 1951 4 The negotiations and Brazil's domestic situation highlight the role that domestic politics played in limiting the drive of dependence in Brazil.

To doubt the importance and influence of domestic politics on a state's foreign policy and security decisions are not the focus of this chapter. The purpose of reaching farther into this black box is not to validate, or invalidate, its bearing on the theory. The theory of how dependence leads to IMC participation is not

\footnotetext{
${ }^{1}$ Edwards, 2013, p. 167; Status of UN Offers of Assistance for Korea 1950; "Memorandum by the Assistant Secretrary of State for United Nations Affairs to the United States Representative at the United Nations"

'Edwards, 2013 pp. 169-70; Status of UN Offers of Assistance for Korea 1950: "Memorandum by the Assistant Secretrary of State for United Nations Affairs to the United States Representative at the United Nations"

${ }^{3}$ The other six states that offered their support following UN Security Council resolutions 82 through 84, were Bolivia, Costa Rica, Denmark, El Salvador, Panama, and the Republic of China (Taiwan). Refer to Status of UN Offers of Assistance for Korea (1950) and Hickerson ("Memorandum by the Assistant Secretrary of State for United Nations Affairs to the United States Representative at the United Nations"). However, among these states, Denmark offered the provision of a transport ship that was turned down because the US did not deem it necessary. Furthermore, shortly after that rejection, Denmark did proceed to provide medical support throughout the war that was accepted by the UNC.

${ }^{4}$ FROTUS, 1951 Volume II, The United Nations; the Western Hemisphere [Document 703]
} 
a two step process as is the case with Bennett, Lepgold, and Unger (1994)'s security contribution model $\left[5^{5}\right.$ Therefore, the purpose is rather to examine how a state high on dependence, but also facing domestic constraint, coped with the problem.

\subsection{Korea: Economic Expectations and Security Fears}

In accordance with the Cairo Declaration of November, 1943, Korea was granted its independence from Japanese colonial rule at the end of WWII. ${ }^{6}$ However, upon the end of the war, the peninsula was divided at the 38th parallel, with the US and Soviet Union administering the southern and northern parts, respectively.

With tensions growing between the US and Soviet Union, the UN called for free elections in 1948, to which the Soviet Union refused to be involved. South Korea held its own elections that year, and soon after it elected Rhee Syngman as president, North Korea formed a communist government of its own under Kim Ilsung 7

Both the US and Soviet Union pulled out their troops that year, and following several border clashes and political disputes between the two Koreas, war broke out on the peninsula when forces from the north invaded the south in June of 19508

Immediately after the North Korean invasion of its southern counterpart, the UN was quick to condemn the actions and called for the North to withdraw its

\footnotetext{
${ }^{5}$ Refer to Chapter 2 for a discussion on Bennett, Lepgold, and Unger (1994)'s model. In short, it proposes that external factors form incentives to contribute to security coalitions, whereas internal factors limit the ability to do so. Also see Baum (2012) on democratic public constraints to contributions to the COTW.

6 The Conferences at Cairo and Tehran: The Cairo Declaration 1943.

7 Edwards, 2013, p. 20.

8 Ibid. pp. 20-21.
} 
troops north of the 38th parallel.$^{9}$ As the North Korean forces continued to march south, the UN asked its members to assist in repelling the forces. In requesting such assistance, it specifically delegated the command of such forces to the US 10

In the US, president Truman authorized General MacArthur to provide a show of force immediately in July 1950.11 Later on in the conflict, China became involved on the North Korean side once US-led UN forces pushed towards the North Korea-China border ${ }^{12}$ After three years of hostilities, an armistice was signed on 27 July 195313

The results of the Korean War were devastating for the South. According to statistics from the South Korean Ministry of National Defense, over 137 thousand South Koreans were killed, and 450 thousand injured over the course of the war 14 For comparison, the entire population in 1953 is estimated to have been a little over 20 million.

In addition to the casualties, its economic and security situation was debilitated. It had already started at a weaker position with respect to the foundations necessary for industrial growth when compared to its northern counterpart. Its capacity for electricity generation and coal production was approximately a quarter of North Korea's, and its national trade a little over one third of what North Korea was trading, before the war ${ }^{15}$ Its security situation was in even more dire shape. The war itself had not officially ended, with hostilities ending only after

\footnotetext{
$\sqrt[9]{\text { Resolution of } 25 \text { June } 1950 \mid 1950}$

10 Resolution of 27 June 1950 1950: Resolution of 7 July 1950 1950

${ }^{11}$ Edwards, 2013. pp. 20-1.

12 Ibid. p. 22.

${ }^{13} \overline{\text { Ibid. }}$ pp. 25-6, Also see Edwards (2006). For a comprehensive historical account of the war itself, refer to Cummings (2010). For an account of the years previous to the war, I recommend Cummings (1990).

${ }^{14}$ Statistics from the MND Institute for Military History. http://www.imhc.mil.kr/user/ indexSub action? codyMenuSeq=70406\&site Id =imhc\&menuUIType $=$ sub\&dum=dum\&boardId=0_ 45408\&page=1\&command=view\&boardSeq=o_47000000000178, accessed March 10, 2016.

${ }^{15} \mathrm{http}: / / \mathrm{www} \cdot \mathrm{imhc} \cdot \mathrm{mil} \cdot \mathrm{kr} / \mathrm{user} /$ indexSub $\cdot$ action? codyMenuSeq=70406\&site Id= imhc\&menuUIType=sub\&dum=dum\&boardId=0_45408\&page $=1 \&$ command=view\&boardSeq=o_ 47000000000178, accessed March 10, 2016.
} 
the signing of an armistice $\sqrt{16}$ Furthermore, in comparison to the North Koreans, who had their main allies(i.e., China and Russia) geographically bordered to their north, South Korea's main ally, i.e., the US, was across the Pacific.

In this context, the US' immediate military assistance at the start of the Korean War and the following years of continued aid resulted in the formation of a relationship with the US where South Korea depended deeply on the former's patronage. Following the end of the war, the US maintained over 220 thousand of its troops on the peninsula in 1954, and an average of 71 thousand for the three years following that. The only other two countries that had more US troops stationed on their soil in 1957 were Japan and France. The ratification of the Mutual Defense Treaty between the two states in 1954 was an important measure to South Korea in terms of the extended deterrence provided by the US ${ }^{17}$ It also benefited from an enormous aid package from the US, receiving 315 million in economic aid (second only to South Vietnam), and 58 million in military aid, in 1955 alone 18

From an early on stage, the US aimed for Japan and Korea to become the center of East Asian cooperation. In a 1955 note to the NSC regarding the US' objectives and courses of action in Korea, the executive secretary explains that Korea and Japan should form a 'community of interest' to lessen the former state's dependence on the US for 'political and moral support. ${ }^{19}$ However, despite the US' pressures for normalizing relations with Japan, South Korea hesitated on the issue, and faced its own domestic instabilities and disturbances. ${ }^{20}$

The volatile domestic political landscape is well represented in the abrupt changes that happened around 1960. Shortly after being re-elected to president

\footnotetext{
${ }^{16}$ American Foreign Policy 1950-1955, Basic Documents Volume I(pp. 724-750)

${ }^{17}$ American Foreign Policy 1950-1955, Basic Documents Volume I(pp. 897-898)

${ }^{18}$ US dollars, current

${ }^{19}$ FROTUS 1955-1957, VXXIII, Part 2, Korea, [Document 24]

${ }^{20}$ FROTUS, 1964-1968 Volume XXIX, Part 1, Korea, [Document 355], [Document 364]
} 
for a fourth consecutive term in 1960, demonstrations in April of that year forced Rhee to resign and flee to the US. ${ }^{21}$ Following a short presidency by Yoon Bosun, Park Chung-Hee became president after a coup in 1961 ${ }^{22}$ President Park subsequently focused on economic development, with an emphasis on neo-mercantilistic policies. 23

In addition to domestic instability, Korea was insecure about the US' alliance commitment to itself despite their high levels of dependence. The state continuously looked for assurances of the reliability of the US' commitment to its security. The fact that the US was starting to become fatigued with providing aid to post WWII countries and demanded that their allies pay their share, and supposed plans for a reduction of US troops did not help the situation. ${ }^{24}$ The apparent drop in economic patronage from the US only added to the country's concerns. Figure 4.1 shows the changes in aid from the US during the ten years following the Korean War. While trade continued to increase, the amount of aid trends downward.

President Park's economic development plan, on the other hand, required an increase of support from its patron, the US. Accordingly, he approached the US regarding the voluntary dispatch of Korean troops to Vietnam, with economic benefits in mind from the beginning ${ }^{25}$ The Chief Presidential Secretary of the time (1963 to 1964) was Lee Dong-Won. In a 1993 interview, he talks about the motivation for Korea's participation in Vietnam that clearly outlines the economic benefits they aimed for through the conflict.

\footnotetext{
${ }^{21}$ FROTUS, 1958-1960 Volume XVIII, Japan; Korea, [Document 295]

${ }^{22}$ FROTUS, 1961-1963 Volume XXII, Northeast Asia, [Document 213], [Document 215]

${ }^{23}$ Choi, 1996 p. 267.

${ }^{24}$ Choi (ibid. p. 273), FROTUS, 1961-1963 Volume XXII, Northeast Asia, [Document 270]; 1964-1968 Volume XXIX, Part 1, Korea, [Document 33]

25 Ibid. pp. 267.
} 
Figure 4.1

Korea: 1953-1963

aid from, and trade with, the US

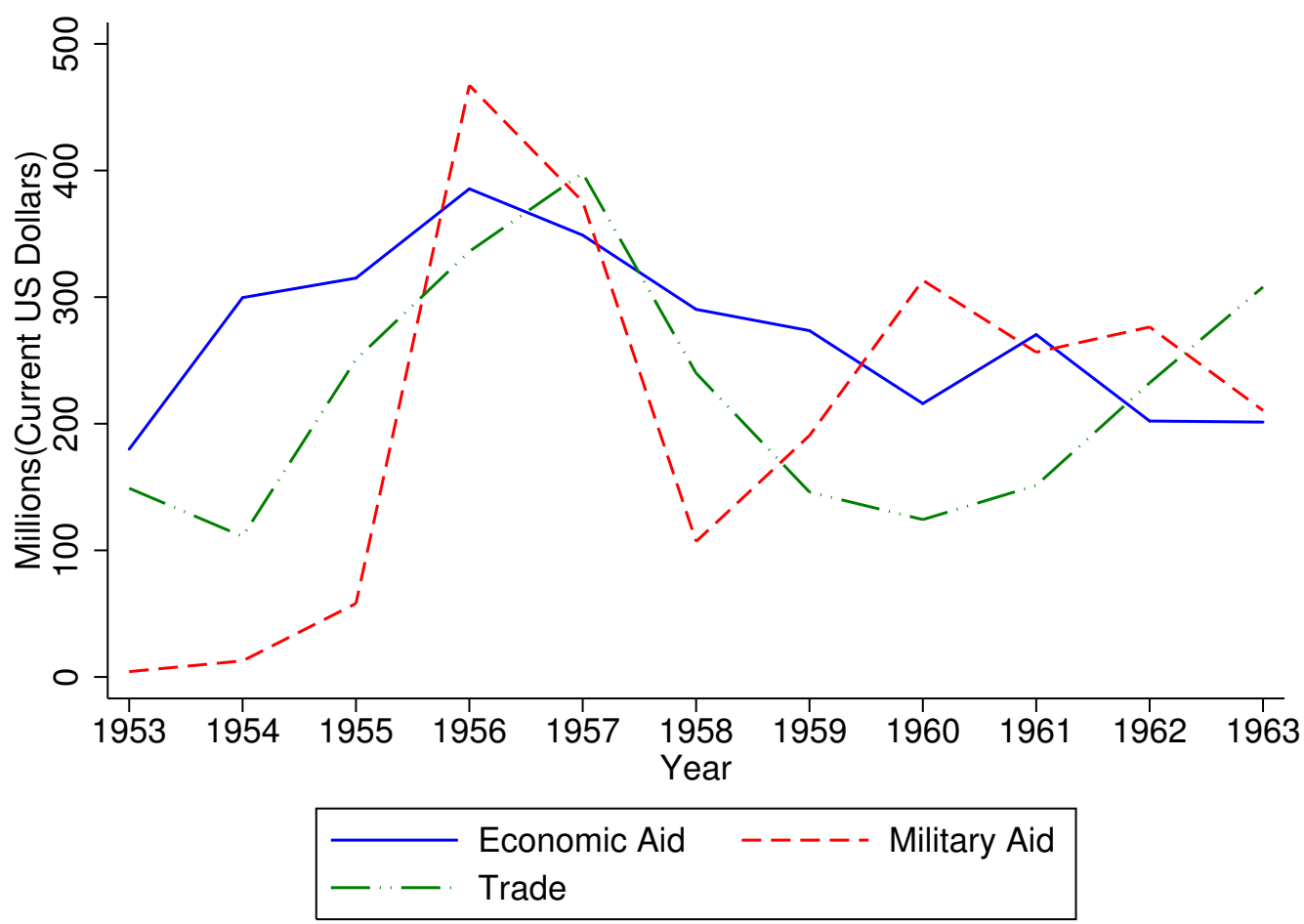

Policy makers in Korea started to feel like they were losing the patronage of the US in the early 60s, and felt a duty to find a plan for economic development. Senior officials were certain that the US would become involved in the war in Vietnam, and felt that the Vietnam War would be the only market that would provide a channel for exports that would in turn lead to a revival of the country's economy. Furthermore, they were also in general agreement that it would provide a market for labor exports, which would solve the largest source of social unrest, which was unemployment. Additionally, international banks required a sovereign credit rating for loans, and the fact that Korea's hope for that was low led them to believe that deploying troops to Vietnam was the only way to open a path to obtaining US 
dollars 26

Furthermore, in a 1965 letter from Rusk to Brown, the Secretary of State talks about a meeting with the Korean ambassador to the US taking place in February. According to his account, the ambassador talked about the US' industrial revitalization during the Korean War, and inquired if they had similar plans for Vietnam. The implicit implication was that Korea was seeking help from the US in gaining economic gains from a war in Vietnam. ${ }^{27}$

These internal conversations and motivations stand in stark contrast to the justification given for the dispatch of Korean troops by the president to the public. Around the time of dispatching its first units to Vietnam, president Park spoke to the public in a speech stating 'moral responsibility' and 'justice' as the reasons for the government's decision.

First, the decision is based on the moral responsibility we have towards collective security and its protection of Asia's peace and freedom.

Second, the decision is according to the conviction that the communist invasion in Vietnam is directly linked to the security of Korea, and hence, our support for Vietnam is an indirect way of defending our own country.

Third, the decision follows the strong sense of justice and firm resolution we as Koreans have. In the past, we ourselves have overcome communist aggression through the support of 16 free world countries, and we can not let an ally become victim of the same.28

\footnotetext{
${ }^{26}$ Original interview in Korean(Choi, 1996, p. 273). Translated by the author.

${ }^{27}$ Choi (ibid. p. 16), citing L.B. Johnson Library Documents (Rusk to Brown, 7 February 1965, Box 254).

${ }^{28}$ Excerpt from speech made by Park on Jan 26, 1965. Translated by the author. Refer to Appendix Cfor full speech and source.
} 
In that and subsequent speeches, he often linked the communist aggression in Vietnam as a direct threat to the security of Korea, resorting to the international struggle of ideologies as the cause of Korea's need to contribute to the military effort. Speaking before the first combat unit's imminent deployment, the president referred to the front lines in Vietnam as a direct extension of the 38th parallel on the Korean peninsula.

If we fail to stop the communist invasion in free Vietnam, we will soon lose all of Southeast Asia, and most definitely not be able to ensure the security of our Republic of Korea. That is why the front lines in Vietnam are a direct extension of our own armistice line 29

Despite such eloquent rhetoric, the actual process of negotiating the terms of deployment, and the related conversations between policy makers show that such considerations were never foremost in the calculations of Korea. The joint statement made by the presidents of the US and Korea following the latter's third official visit to the US in May of 1965 also lends further insight. ${ }^{30}$ The order of items announced provides a hint to the amount of importance put on each issue during the meeting between the two. This was at a time that Korea had already contributed troops to Vietnam, and when they were negotiating the terms of deploying an entire division of combat troops. Immediately following the general expression of appreciation for the contributions Korea had already made to Vietnam, the first point made by the US was a reaffirmation of its devotion to the defense of South Korea. In addressing this point, the US emphasized its intentions of honoring the Mutual Defense Treaty of 1954, and maintaining a strong military presence on the Korean peninsula.

\footnotetext{
${ }^{29}$ Excerpt from speech made by Park on Oct 12, 1965. Translated by the author. Refer to Appendix C for full speech and source.

${ }^{30}$ Johnson, 1966a. Item 257.
} 
The latter point of maintaining a military presence in Korea was actually the first subject president Johnson brought up while trying to get president Park to agree to deploying a combat division to Vietnam. ${ }^{31}$ The US was aware that Park was sensitive to maintaining a certain level of US troops in Korea, and Johnson accordingly not only started the conversation by stating that 'as long as Korean soldiers are in Southeast Asia, there will be no reduction in U.S. strength on the peninsula,' but reiterated this commitment twice during their first meeting. ${ }^{32}$

Regarding economic benefits, the US confirmed the continuance of economic and military aid on two separate occasions throughout the joint statement, but included a clause that aid was conditional on the normalization of Korea-Japan relations ${ }^{33}$ Park emphasized the importance of expanding trade to attain South Korea's goal of economic growth, and requested that the US cooperate in export expansion and assist Korea in gaining opportunities to participate in US funded procurements. 34

These various points consistently indicate that South Korea was motivated primarily by expectations of receiving economic benefits when participating in the Vietnam War. As for security dependence, two points make it clear that Korea was motivated by a fear of retribution in this aspect. First, the concerns regarding the withdrawal of US troops and the assurances made by the US that their troops would remain on the peninsula as long as Korea contributed to the Vietnam War show that Korea felt pressured to contribute in order to retain the deterrence provided by the troops in their country. Second, the reiteration of the

\footnotetext{
${ }^{31}$ Sarantakes (1999. p. 434), FROTUS, 1964-1968, Volume XXIX, Part 1, Korea, [Document 48]

${ }^{32}$ Sarantakes (ibid. p. 434), FROTUS, 1964-1968, Volume XXIX, Part 1, Korea, [Document 48]

${ }^{33}$ The Treaty of Basic Relations Between Japan and Korea was subsequently signed by Korea on August 13. Refer to Item 657 of Johnson (1966b). Also see Sarantakes (1999. p. 427).

${ }^{34}$ Refer to Sarantakes (ibid. pp. 433-435) for a historical account of the actual meeting between the two presidents.
} 
US' commitment to honor their defensive commitment to Korea shows that this was also a primary concern for the latter state.

In addition to the main points of dependence, another problem that pushed Korea to participate are the facts that it did not have much to offer the US at the time, and did not have an alternative patron to turn to either. While the peninsula presented a strategically valuable doorway to East Asia for the US at the height of the Cold War, Japan and Taiwan were situated nearby and the US had a firm footing in both. The southern part of the peninsula was also not endowed with any natural resources uniquely specific, or of particular value to its patron. The Korean War itself had been a war caused by a clash of ideologies from the onset, and the high level of anti-communism in South Korea also made it virtually impossible to switch patronage to the Soviets. In the western hemishphere, most of the other traditional major powers were still recovering from WWII, leaving the US as the only option as a capable patron. The related points and how they fit into the mechanism of dependence leading to IMC participation is summarized in Figure 4.2 . 
Figure 4.2

Korean Dependence and Vietnam Participation

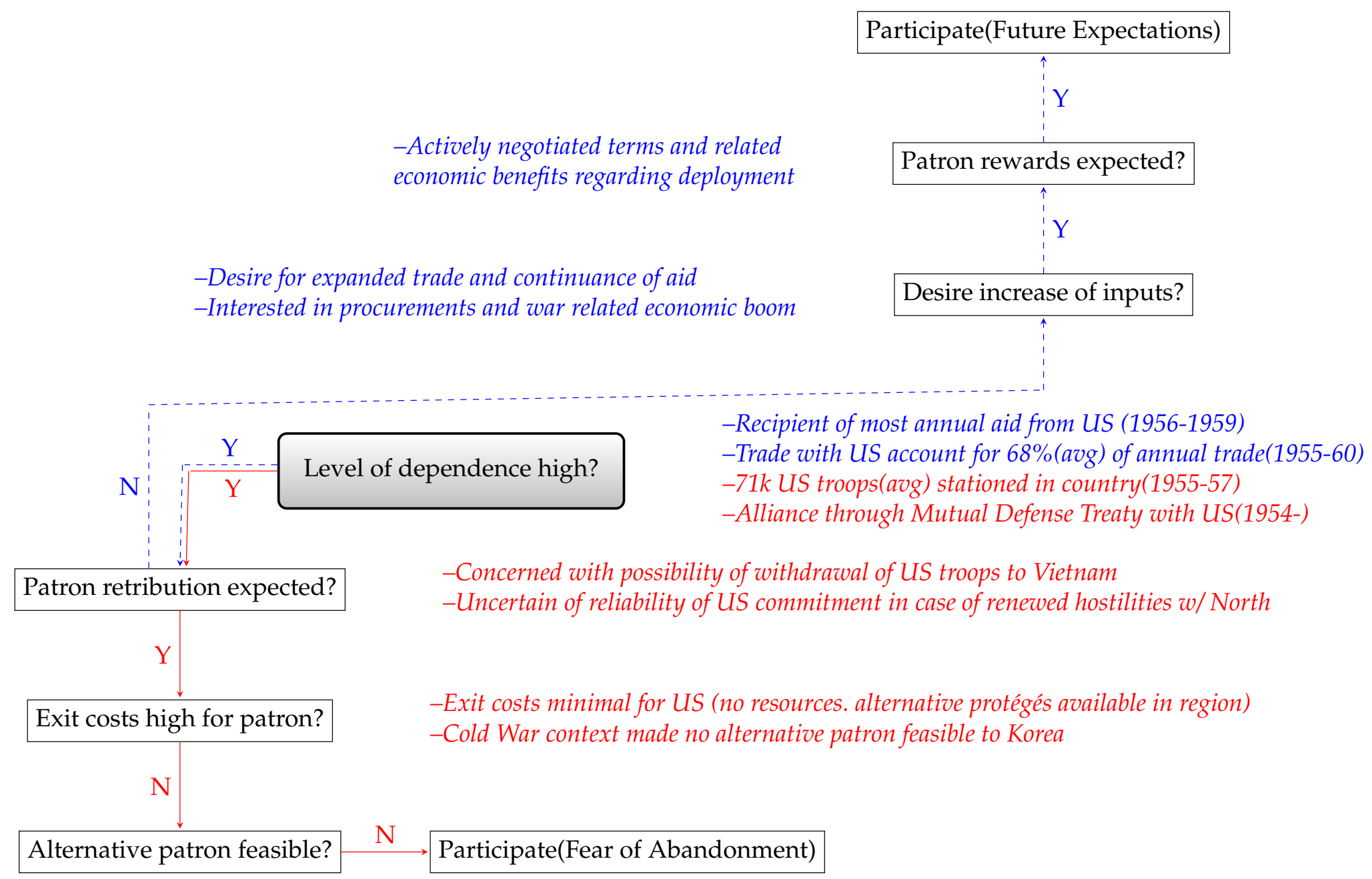




\subsection{Brazil: Economic Expectations and Domestic Re- straint}

Brazil initially offered military assistance to the Korean War, but failed to provide specific information on substance or timing. The offer was later deferred by the US JCS. ${ }^{35}$ According to Edwards (2013), Brazil 'dragged its feet' regarding making actual contributions following its initial positive response to the United Nations Security Council resolutions of 27 June, 1950.

In order to understand the case of Brazil, we need to better understand the political situation of the state at the time. There is evidence that while external factors provided strong incentives for participation in the Korean War, domestic factors strongly limited its ability to do so. The rest of the narrative will demonstrate that Brazil felt burdened to somehow convince the US of its sincerity, and that it was fairly afflicted by its necessity to maintain a good relationship with the US.

Brazil gained its independence from Portugal in 1822, and until the military staged a coup in 1889, remained an empire under the rule of Pedro I and II However, political tension between the military and the government led the former group to lead a coup that brought down the empire in 1889.37

The military started to become publicly involved in Brazilian politics even before this incident. Leading up to the coup of 1889, the military first publicly debated the government in 1879 when the government tried to pass a bill that would reduce the size of the military: ${ }^{38}$ In 1883, there was further discord between the two regarding a compulsory insurance fund payment for military

\footnotetext{
${ }^{35}$ Edwards, 2013, pp. 168-9; Status of UN Offers of Assistance for Korea 1950.

${ }^{36}$ Burns, 1980. Chapter 2; Smallman, 2002. pp. 10-16.

${ }^{37}$ Burns, 1980 pp. 284-5; Smallman, 2002 pp. 17-8.

${ }^{38}$ Burns, 1980, p. 283.
} 
officers ${ }^{39}$ Such events, compounded with a traditional distrust of the military by the elites, led to the establishment of the Clube Militar(Military Club) in 1887 40 The club was intended to be the political instrument of the military; to represent its interests and be the vocal instrument of any grievances. ${ }^{41}$ This club continued to play an important role in framing the political views of the military, and later came to play an important role during Brazil's decision regarding the Korean War. The military general who would later lead the coup in 1889, and become the first head of state of a new republic, Marshal Deodoro da Fonseca, was elected as its first president ${ }^{42}$

Ever since the military played a critical role in overthrowing the empire and establishing Brazil as a republic, it continued to be closely related to, and actively involved in, its politics. Immediately following the military coup d'éta, army officers governed ten of the twenty states, and subsequent important political changes throughout the first half of the twentieth century in Brazil were either brought about directly by the military, or made possible with the support of itself or some of its factions 43

One of the most influential and controversial political figures in Brazil during this period is president Vargas. With the help of Lt. Col. Goés Monteiro and factions within the military, he came to power following a revolution in 1930 44 Vargas continued to serve as president for an uninterrupted fifteen years; first as chief of the provisional government from 1930 to 1934, then as president elected by congress from 1934 to 1937, and then as dictator (the Estado Novo period) for eight years until he was deposed by the military in 1945.45

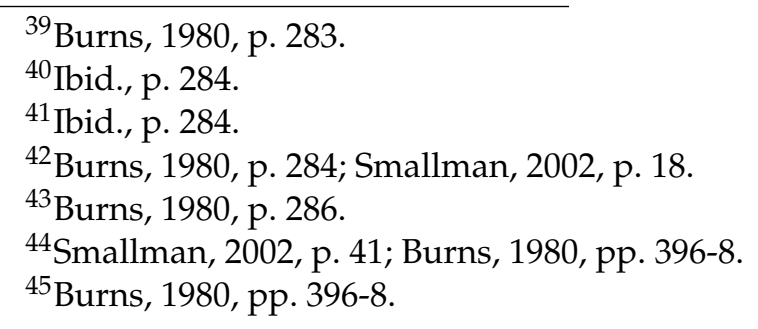


The military continued to play an important role in Brazilian politics during this period as well. They were deeply involved in the bureaucracy as well as its economic policies. Military officers served in a host of government agencies as is evidenced by the fact that six generals and seventy-nine officers served in civilian capacities as late as 1951.46

When Brazil was faced with the decision of participating in the Korean War, Vargas was once again president. However, the political situations that led to his being president at the time put him in a precarious state.

Vargas' rule as dictator was upended by the military in 1945. Following their participation in WWII, Brazil, like many other states throughout Latin America continued to feel the pressure for democratization. While president Vargas also scheduled elections to take place in 1945, some of his actions made many, including key figures in the military, to suspect that he was preparing some other political move. These actions included such events as suddenly re-scheduling the elections to a different date, and appointing his brother to the post of chief-of-police in Rio de Janeiro. Subsequently, the military staged another coup in October of that year which forced Vargas' removal. While the military did not interfere with the following elections, it continued to maintain a significant influence in the political arena $\sqrt{47}$ Both presidential candidates were from the military, and Dutra, who was the minister of war and a marshal in the Brazilian army, was elected president. ${ }^{48}$

While the military continued to be deeply involved in politics in general, it also proved to be somewhat committed to democracy at this time. In the next presidential election of 1950, Vargas returned to run for the presidency and

\footnotetext{
${ }^{46}$ Smallman, 2002, p. 66.

${ }^{47}$ Burns, 1980, pp. 436-8; Smallman, 2002, p. 83.

${ }^{48}$ Smallman, 2002, p. 83.
} 
won 49 This was in part possible due to some of president Dutra's policies, and also because of a struggle among military factions. The struggle was between those that endorsed the participation of foreign powers in its economic affairs (the internationalists) and those that opposed it (the nationalists) 50

Vargas won the election with the help of the nationalist faction. Moreover, while president Dutra was determined to prevent Vargas' return to the presidency, the latter's assumption of office was made possible in part due to the support he received from key factions in a split military. ${ }^{51}$

Around the time of Vargas' election, and while internal struggles in the military were ongoing to ensure his return to the presidency, the Korean War became a hotly debated issue in Brazil, especially in the military. At the center of this debate stood an anonymously penned essay that had run in the Military Club's journal ${ }^{52}$ The article itself made questionable claims regarding the origins of the Korean War, and its accuracy in depicting the actual events happening in the Asian peninsula were highly questionable. However, it succeeded in igniting a debate within the military regarding Brazil's alliance with the US as well as its overall foreign policy: 53

While Vargas was able to return to the presidency with the support of the nationalist factions within the military, the Korean War debate posed a problem. The Military Club and the nationalist faction that did not support the Brazil-US alliance made it problematic for him to openly offer Brazil's support to the US' effort in Korea, let alone offer the participation of his country's own troops. Despite these limitations, there is abundant evidence that Vargas wanted to, and

\footnotetext{
${ }^{49}$ Burns, 1980, pp. 444-5; Smallman, 2002, p. 130.

${ }^{50}$ Smallman, 2002. pp. 125-7; Burns, 1980, pp. 443-4.

${ }^{51}$ Smallman, 2002. pp. 125-6, 135.

52 Ibid. pp. 133-7.

53 Ibid. pp. 137-8.
} 
needed to, use the Korean War for Brazil's advantage. 54

Upon the UN's call for additional troops in June of 1951, and knowing the US wanted Brazil to send a contingent to fight, Vargas sent his army chief of staff, Goés Monteiro, immediately to the US the following month 55 However, upon doing so, he also tasked Monteiro to only make vague promises of troop deployments, while simultaneously trying to revise existent Brazil-US treaties more favorable to his nation. According to Smallman (2002, p. 150), 'the entire effort depended upon maintaining the United States' expectation of Brazilian troops without committing to send them.'

These goals are explained clearly in a letter Monteiro wrote to the president of the Military Club while he was in Washington. In the letter, Monteiro states that the securement of US financial aid was his first priority, and security issues second. He further wrote that the UN call for troops was his least important concern 56

With the pressure of competing military factions, and stuck between internationalist and nationalist views of foreign policy, it is not surprising that president Vargas was cautious of openly and readily sending troops to the Korean War effort. His demise from the presidency and subsequent return to politics was made possible by, and with the help of, the military, and since most of the main forces within that organization were against deployment, there was little room for him to maneuver.

Despite such limitations, it is also fairly clear that Vargas viewed the situation as an opportunity to receive economic and political benefits from the US. The fact that he tasked his army chief of staff to specifically try and maintain the US'

\footnotetext{
${ }^{54}$ Smallman, 2002, p. 150.

55 Ibid. p. 150.

${ }^{56}$ Smallman (ibid. p. 150), citing General Goés Monteiro to Estillac August 3, 1951, Arquivo Nacional, Rio de Janeiro, Arquivo Goés Monteiro
} 
expectations of Brazilian troops, while not making any specific commitments, show that the president was highly aware of the importance of, and benefits to be had, from the US.

During his visit to the US, Monteiro shared a document that (apparently) contained 'his written instructions received from President Vargas' during a meeting on August 17, 1951. According to a memorandum written by the Officer in Charge of Brazilian Affairs(Kidder) shortly after the meeting, the eight point document laid out the priorities of his negotiations with the US. ${ }^{57}$

The document first states that the foremost priority for Brazil was the consolidation of its internal security, and then proceeds to its second point of economic development. Regarding economic development, the document clearly shows that Brazil linked this as a necessary condition for its participation in Korea, and that it was also aware that its abundant natural resources was of value to the US as well.

Brazil must develop itself industrially and problems of transportation and power must be solved. Solving of these problems is of direct interest to the United States as [sic] regards the supplying by Brazil of scarce strategic minerals. 58

... make clear that Brazilian assistance in Korea and in defense of the free world if a third world war should break out would depend upon the amount and speed of the economic and military assistance received from the United States. The greater the help received from the United States, the sooner Brazil could act 59

\footnotetext{
${ }^{57}$ FROTUS, 1951 Volume II, The United Nations; the Western Hemisphere [Document 713]

${ }^{58}$ FROTUS, 1951 Volume II, The United Nations; the Western Hemisphere [Document 713]

${ }^{59}$ FROTUS, 1951 Volume II, The United Nations; the Western Hemisphere [Document 713]
} 
Relatedly, Brazil was also intent on receiving the US' assistance with developing its petroleum program. A letter from the embassy in Brazil to Kidder talks about the 'nationalistic fervor' Brazil had for the program and how it viewed receiving the necessary equipment from the US as a politically important matter 60

President Vargas clearly went out of his way to appease the US with promises of troops in exchange for an increase in benefits. However, the high amounts of domestic pressure he was facing may have proved to be too high for him to actually follow through. His precarious situation is highlighted by the fact that he later committed suicide after being deposed by the military once again in 1954.61

\subsection{Conclusion}

The cases of South Korea and Brazil illustrate that both states negotiated their participation in US-led IMCs with considerations of US benefits primarily in mind. In South Korea's case, both logics leading to IMC participation are evident. In terms of economic dependence, the preponderance of the evidence suggests that the state was primarily driven to participate in the Vietnam War with expectations that it would assist their prospects of achieving expanded trade not only with the US, but that the US would also help them gain a favorable position in South Vietnam and beyond. As for security dependence, most points suggest that Korea attempted to increase the reliability of the US respecting its alliance commitment to itself through its contributions to Vietnam, and that it was also

\footnotetext{
${ }^{60}$ FROTUS, 1951 Volume II, The United Nations; the Western Hemisphere [Document 705]

${ }^{61}$ Smallman, 2002, p. 174.
} 
concerned with a possible reduction of US troops on its soil that could lead to an increased possibility of renewed hostility from North Korea.

As for Brazil, while it did not actually participate in the Korean War, the fact that it actively attempted to persuade the US of its sincerity and intentions of doing so evidence a sense of burden due to its interest in receiving US assistance. While the state was not as dependent on the US as South Korea was in the 1960s, the state was still interested in receiving an increase of benefits from the US, primarily in terms of aid and assistance with its energy program. Brazil specifically linked its economic development as a necessary condition for participating with troops in the Korean conflict. While the fact that it failed to actually participate can be construed to the domestic restraint imposed on the leadership at the time, the fact that the president tried to present the US with a facade of deploying troops to Vietnam is evidence that he felt the need to appease the US and its interests.

While the threat of communism in both conflicts definitely contributed to the rhetoric and justification for participation, the distance of each state to the respective conflicts and the limited nature of the conflicts themselves precludes that it was a primary cause of war diffusion or balancing behavior. Regarding the balancing of threats, there is scarce evidence that South Korea felt an immediate threat by North Vietnam, and by extension China. If the justification given by the president at the time is to be believed, it is hard to understand why the more closer threat of communism supported by China at its immediate border to the north did not command more attention than Vietnam. The perception of threat is not only driven by power, but the combination of power and distance is paramount. The explanations that one operating in the Willingness/Opportunity framework could set forth are even less convincing. States with much less 
'opportunity' than Brazil, those with much less material power and equally as distant to the conflict, did not forego participating in the Korean War.

While the two cases do not represent the entirety of methods leading to IMC participation, they are valuable to the extent that they do highlight the proposed mechanisms of expectations and fears. The quantitative analyses in the previous chapter already found support for the argument that states dependent on an IMC leader are more likely to offer their support in that IMC. While those analyses observed states in the system, their levels of dependence on the US, and their subsequent participation, they were not able to actually parse out how high levels of dependence led to participation. The two cases presented here illustrate that process. 


\section{Chapter 5}

\section{After Following the US into War:}

\section{Are States Right to Do So?}

This chapter transitions the focus to a question that is different, but highly related, to the original research question proposed in the introduction of this project: If states participate in IMCs with the expectation that doing so will result in some form of reward, are they right to do so? It essentially aims to determine if the expectations that lead states to go 'above and beyond' are justified. Unlike the conjectures made by Walt regarding the relationship between alliances and aid, I argue that the politics of inattention in asymmetric dyads lead to no changes in aid relationships in the long term. The argument is then tested through four US-led IMCs. 


\subsection{Introduction: Expectations and Outcomes}

Protégés participate in IMCs with the belief that such actions will lead to relative increases in the benefits they receive. Being dependent on a patron for its economy or security, protégés attempt to secure such benefits through IMC participation. However, these are expectations. Whether or not such expectations are actually met is the question that naturally follows. Hence, we need to determine if the outcomes of IMC participation actually follow what states expect.

Making this assessment has important policy implications for both protégés and patrons. For protégés, finding that the outcomes of contributing to wars at the peripheral of their security interests lead to enduring improvements in the levels of benefits they attain from their patron not only justify their participation to some extent, but also provide them with an additional tool to wield when seeking increases in such measures. If participation does not lead to any noticeable differences in how a patron treats them vis-à-vis non-participants, states need to significantly reconsider the costs and benefits of participating in subsequent patron led IMCs.

Warfare in the modern age is increasingly turning into a multi-lateral effort. Unless a major power is ready to wage a war on its own, the answer to this same question has vast implications for it as well. If its protégés feel that they are not being compensated for their efforts, and other states in the system witness such outcomes as well, the patron will undoubtedly have increased difficulty in employing the assistance of others in its IMCs as the understanding of the issue spreads across the system. On the other hand, if the outcomes point in the opposite direction, it should have an abundance of willing participants to choose from. 
The expectations that lead to IMC participation are presented in Figure 5.1 . The columns indicate participation status, and rows a state's level of dependence. The expectations regarding benefits to be received from a patron are indicated within each cell. The point is that participant states expect a relative increase in their benefits when compared to others with a similar level of dependence(prior benefits received) that do not participate. Whether a state participates due to an expectation of rewards, or out of the fear of retribution, they are right to participate as long as the benefits gained after the war justify the costs.

\section{Figure 5.1}

Expectations of States

\begin{tabular}{|c|c|}
\hline \multicolumn{1}{c}{ Participate } & Participate \\
\hline Decrease & Maintain \\
\hline Maintain & Increase \\
\hline
\end{tabular}

\begin{tabular}{|c|c|c|}
\hline & Participate & Participate \\
\hline$\uparrow$ & Maintain & Increase \\
\hline Dependence & & \\
\hline$\downarrow$ & Maintain & Increase \\
\hline
\end{tabular}

However, the outcomes may not follow expectations. Compared to nonparticipants, if there is no relative change in the modes of dependence for IMC participants, states should reassess their cost-benefit calculations when considering participating in subsequent IMCs led by a patron.

\subsection{Rewards and the Politics of Inattention}

In addition to his focus on threat perception, Walt also devotes attention in his book to the impact of economic and military aid to the formation of alliances.$^{1}$ Through his case studies, he concludes that there is no definitive evidence linking aid to alliance formation. He argues that the apparent correlation between the

\footnotetext{
${ }^{1}$ Refer to Chapter 7 of Walt, 1987 .
} 
two is a form of selection bias because states sponsor others that are either friendly to itself or those that it anticipates to become close to..$^{2}$ Therefore, for Walt, 'aid is the manifestation of political alignment,' not the cause thereof, and an aid relationship 'is just another form of balancing. ${ }^{3}$ More specifically in relation to the question at hand, Walt argues that the support provided by one state to another is the result of responding to particular challenges..$^{4}$

Applying this to IMC participation, Walt's conjecture would expect that states participating in an IMC will witness an increase in the amounts of aid they receive from the patron leading that coalition. For the IMC leader, the war effort presents a 'particular challenge,' and since the act of cooperating with a coalition leader displays a state as being 'friendly,' contributions to the coalition (or, in the vein of Walt, the act of alignment) should result in the formation of an aid relationship, i.e., an increase of aid from leader to participant. $5^{5}$

- Conjecture: States that participate in an IMC will receive more aid from the leader of that IMC than those that do not.

Economic and Military aid is definitely a viable form of benefits a patron could use to bribe or reward a protégé to do something it would rather not ${ }^{6}$ Unlike trade, it is something a patron could manipulate to fit its policy preferences instantly. However, an important aspect of the question of aid as a form of rewards that is not often addressed is the timeframe: how long a state benefits from an increase in aid for their participation. Will states only benefit with increased aid for the duration of their participation, or will the display of being a friendly and compliant protégé lead to a long lasting aid relationship? If the

\footnotetext{
${ }^{2}$ Walt, 1987, pp. 218, 221.

3 Ibid. pp. 42, 224.

$4 \overline{\text { Ibid. }}$ p. 222.

${ }^{5}$ Also see Tago (2008) for additional work on IMC participation and rewards.

${ }^{6}$ Also see Newnham, 2008
} 
latter assertion is true, states would indeed be right to think that participating in IMCs lead to long term benefits in the terms of aid. However, if the former is true, an apparent increase in aid would actually be nothing more than a patron paying off a state for its immediate costs of war.

I argue that the increase in rewards a protégé receives from a patron for its cooperation is only temporary. The relative increases should not be expected to last after the termination of a war. This is primarily due to the nature of asymmetry in the relationship between a patron and protégé.

By their very nature and definition, patrons are most likely to be large, capable states, and protégés relatively small. This makes the relationship asymmetric, and with asymmetry come the different political attitudes of each actor. An important point from Womack's theoretical work on asymmetrical relationships between states is that the way larger and smaller states assess their environment and act are fundamentally different. ${ }^{7}$ Termed the 'politics of asymmetric attention,' Womack argues that the larger state in a relationship follow the politics of inattention, while the smaller follow the politics of overattention. ${ }^{8}$ This is due to the differences that their actions have on each other, which is in turn affected by the amount of exposure they have to each other. While the actions of a larger state loom large on the horizon of the smaller state, the former has more domestic concerns to consider relative to the small state with which it is dealing with, and also has more international relationships to handle..$^{9}$ For the larger state, it is likely to have a number of other external concerns that are of equal or greater importance to itself than the small state alone. 10

\footnotetext{
${ }^{7}$ Womack, 2006, Womack, 2016.

${ }^{8}$ Womack, 2006, p. 77; Womack, 2016, pp. 47-51.

${ }^{9}$ Womack, 2006, p. 82; Womack, 2016, pp. 47-51.

${ }^{10}$ Womack, 2006, p. 80; Womack, 2016, pp. 47-51.
} 
While the focus of Womack's work is primarily on the conflictual nature of such asymmetric politics, the framework can be extended to apply to asymmetric patron-protégé relationships. While protégés might expect a firm formation of an aid relationship for their one time IMC participation, a patron will have other international issues waiting in line for them to pay attention to following the war. Subsequent crises and other events may demand it to divert aid that was once increased to former IMC participants to ones that are contributing to current causes, or, the war effort may have taken a toll on the patron's domestic situation, leading it to divert such resources inwards. Regardless of the cause, I argue that the politics of inattention by a patron will lead it to eventually be unable to make meaningful distinctions in how it treats past contributors vis-à-vis noncontributors, instead opting to focus on current and future prospects.

For these reasons, unlike the conjecture made by Walt, formulating hypotheses regarding the effect of IMC participation on the reception of aid needs to be cautious to account for the aspect of time. Hypotheses $\mathbf{H} \mathbf{1}$ and $\mathbf{H} \mathbf{2}$ do so in accordance with the arguments I make above.

H1: States that participate in an IMC will receive more aid from the leader of that IMC than those that do not, for the duration of their participation.

H2: States that participated in an IMC will not receive more aid from the leader of that IMC than those that did not, after the conclusion of the war. 


\subsection{Korea in the Vietnam War: A Benchmark Case for the Rewards for Participation Argument}

In 1965, South Korea negotiated terms with the US for sending combat troops to Vietnam. The concessions offered by the US included significant economic aid packages in the form of increased support for social programs and an agreement to buy supplies for Vietnam from Korean suppliers. Furthermore, through a summit meeting between president Johnson of the US and Park of South Korea, the latter was assured that the Vietnam effort would not divert American forces deployed in Korea to Vietnam, as long as Korea contributed forces to the US' war effort 11

The following year, the US and Korea were once again negotiating terms for the deployment of a second division by the latter state. The US agreed to 1) pay the costs associated with the ROK military's deployment, 2) assist in the modernization of its forces, 3) give Korean firms priority in procurements related to the Vietnam War, and 4) help foster economic development in Korea. ${ }^{12}$

South Korea is often the benchmark case for the argument that some sort of 'aid for participation deal' exists between a patron and its protégé. ${ }^{13}$ However, such arguments are problematic for several reasons. More broadly, historical accounts and case studies regarding how states are 'rewarded' for contributing to US led wars are susceptible to be biased by 1) their focus on one mode of dependence, 2) limited time scopes, 3) a failure to distinguish promises from actual outcomes, and 4) a focus on one state.

During the five years before the Vietnam War started in 1965, South Korea was receiving an average of 1.48 billion dollars in military aid annually from the

\footnotetext{
${ }^{11}$ Sarantakes, 1999 . pp. 433-40.

12 Ibid. p. 439.

${ }^{13}$ Sarantakes, 1999 Tago, 2008
} 
US. ${ }^{14}$ The average annual military aid they received for the five years after 1965 indeed increased to 1.74 billion. The increase from 1.48 to 1.74 billion in military aid seems to confirm that the US held up their side of the bargain, and that more generally, there indeed is an 'aid for participation deal' for IMC participation. 15

However, in terms of economic aid, the five year annual average before the war was 1.35 billion, and it dropped to 1.1 billion for 1965-1969. The aggregate of the five year average of annual military and economic aid combined is 1.83 and 1.84 billion, respectively, for the period prior to, and after, Korea's participation. The five year annual average after the termination of the US' involvement in the Vietnam War(1973-1978) in 1973 is even more interesting because the amounts drastically decreased to 783 million, and 229 million, respectively.

Historical accounts and case studies focusing on South Korea's war participation and the subsequent increases in military aid it received would fail to recognize the fact that such increases were largely offset by decreases in economic aid. Furthermore, a focus on immediate increases in benefits during the war would fail to consider the fact that those increases receded drastically once the war was over. The decrease in economic aid also indicates that the US did not follow through with its promises to 'increase support for social programs' and 'foster economic development.'

Figure 5.2 depicts the trend of US aid to South Korea, five years prior to, and three years after Korea's participation in 1965. The picture seems to confirm that Korea's participation in the Vietnam War led to an increase in aid. The clear decline in aid makes a sharp rebound at the point of Korea's participation in 1965, and the growth in military aid is especially remarkable, seemingly lending support to the claim that participation leads to an increase in benefits.

\footnotetext{
${ }^{14}$ from 1960 to 1964

${ }^{15}$ Tago, 2008.
} 
Figure 5.2

US Aid to Korea : 1960-1968

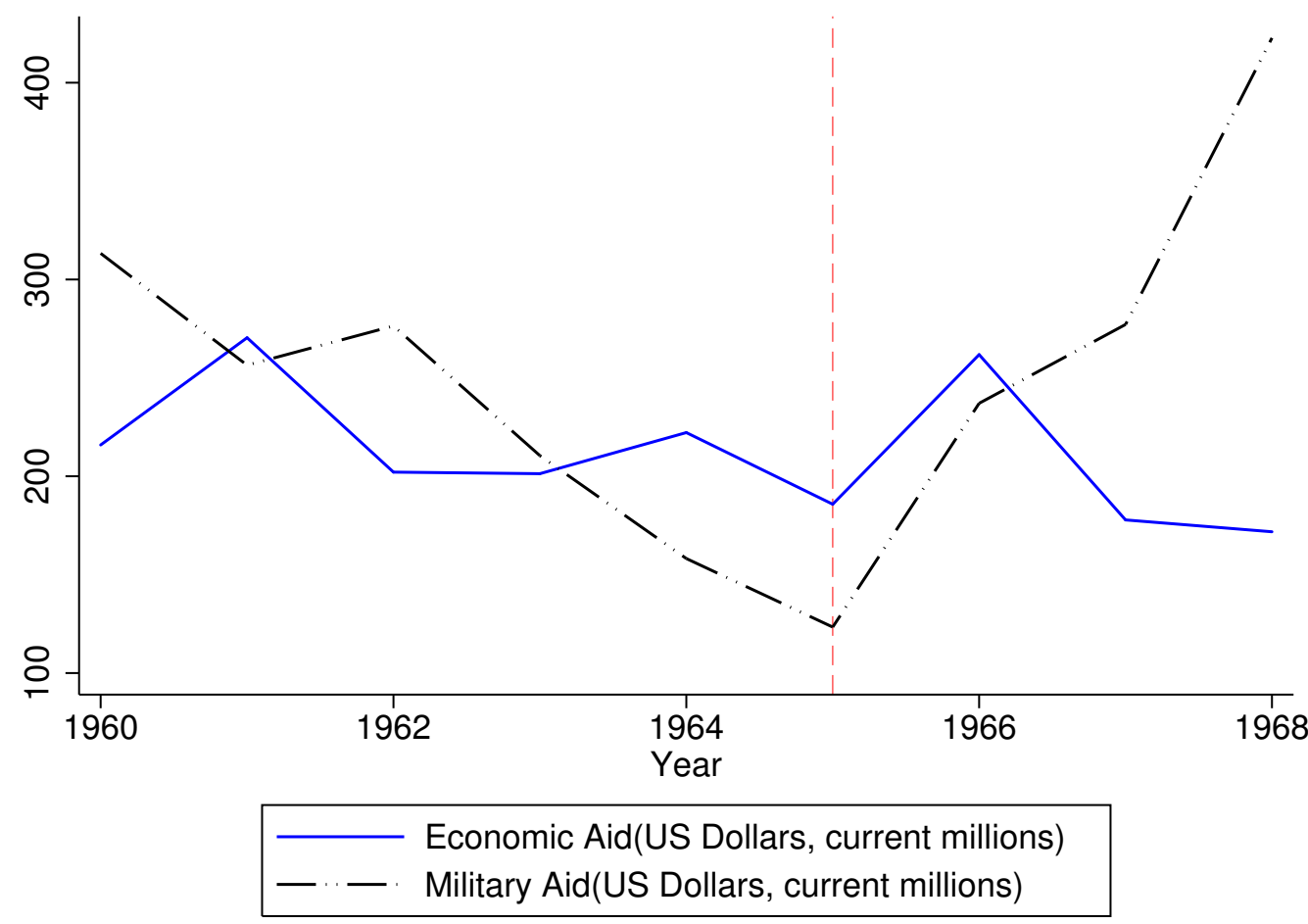

However, the trend for economic aid in Figure 5.2 already stands in stark contrast to the large increase in military aid. Furthermore, increasing the timeline to the US' departure from the war in 1973 and the years following that paint a very different picture. Figure 5.3 depicts the trend of US aid to South Korea, five years prior to Korea's participation in 1965, and seven years after the US' departure from the war in 1973. The apparent increase in military aid returns to pre-war trends after the end of the US' investment in the conflict, and there appears to be no discernible difference for the trend of economic aid.

Another problem with using Korea as the benchmark case is that it misses a variety of other states that also went out of their way to support the US' effort. In addition to South Korea, several other states including Australia, New Zealand, and the Philippines also participated in the conflict on behalf of the US. Despite 
Figure 5.3

US Aid to Korea : 1960-1980

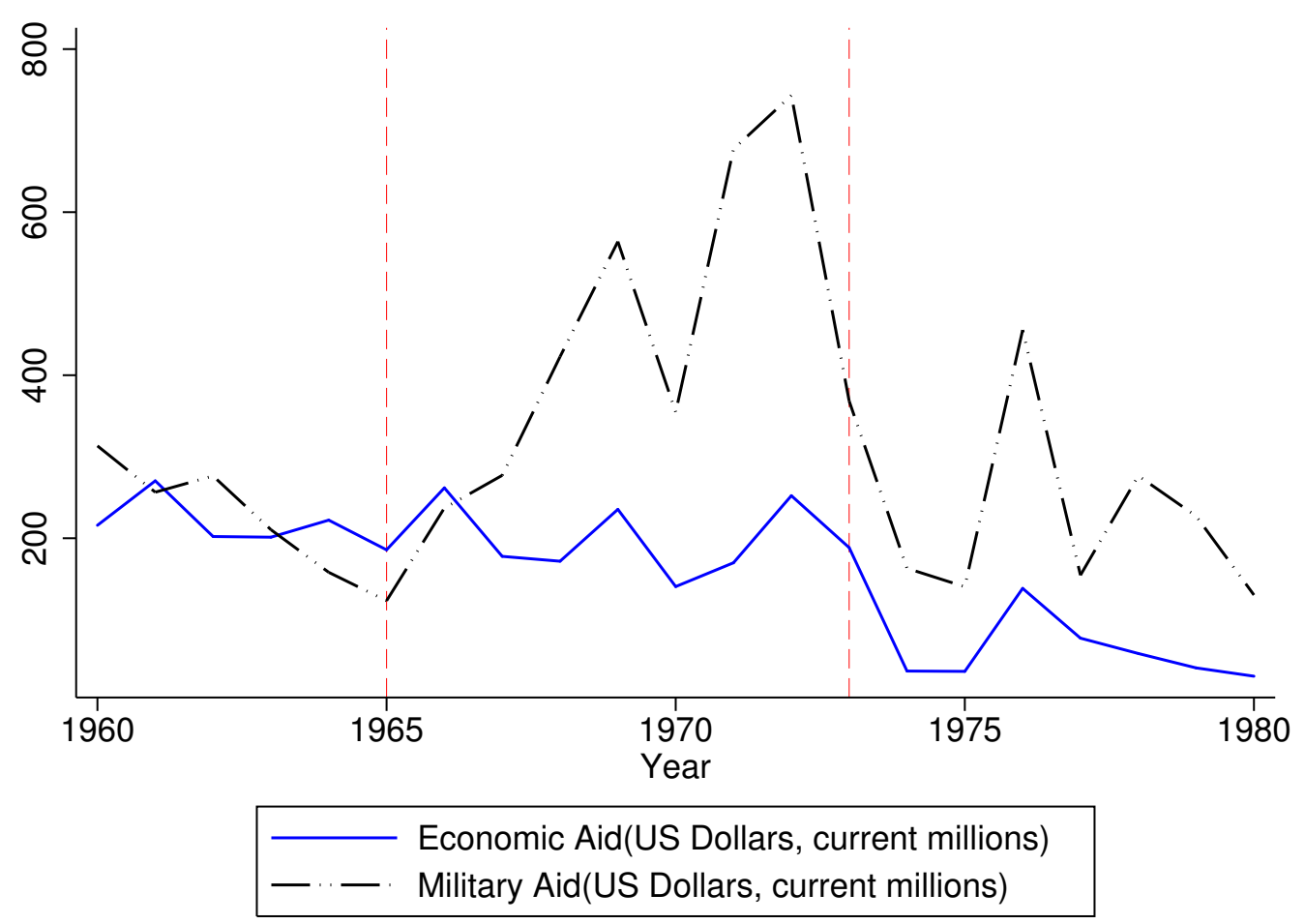

their participation in a war that was highly unpopular to the international community in general, they are seldom mentioned in discussions about support for Vietnam and rewards. Figure 5.4 depicts the military aid received by each of the states that participated on the US' side. As one can easily see from the amounts and changes in military aid these states received, South Korea is the exception rather than the norm. 16

\footnotetext{
${ }^{16}$ Figure $B$.2 in Appendix $B$ provides the same time series in percentage changes from military aid received by each state in 1965. Figure B.3 in the same appendix provides individual time series for each participant state, and Figures B.4 through B.13 provides those for non-participant states.
} 
Figure 5.4

Military Aid to Participant Countries

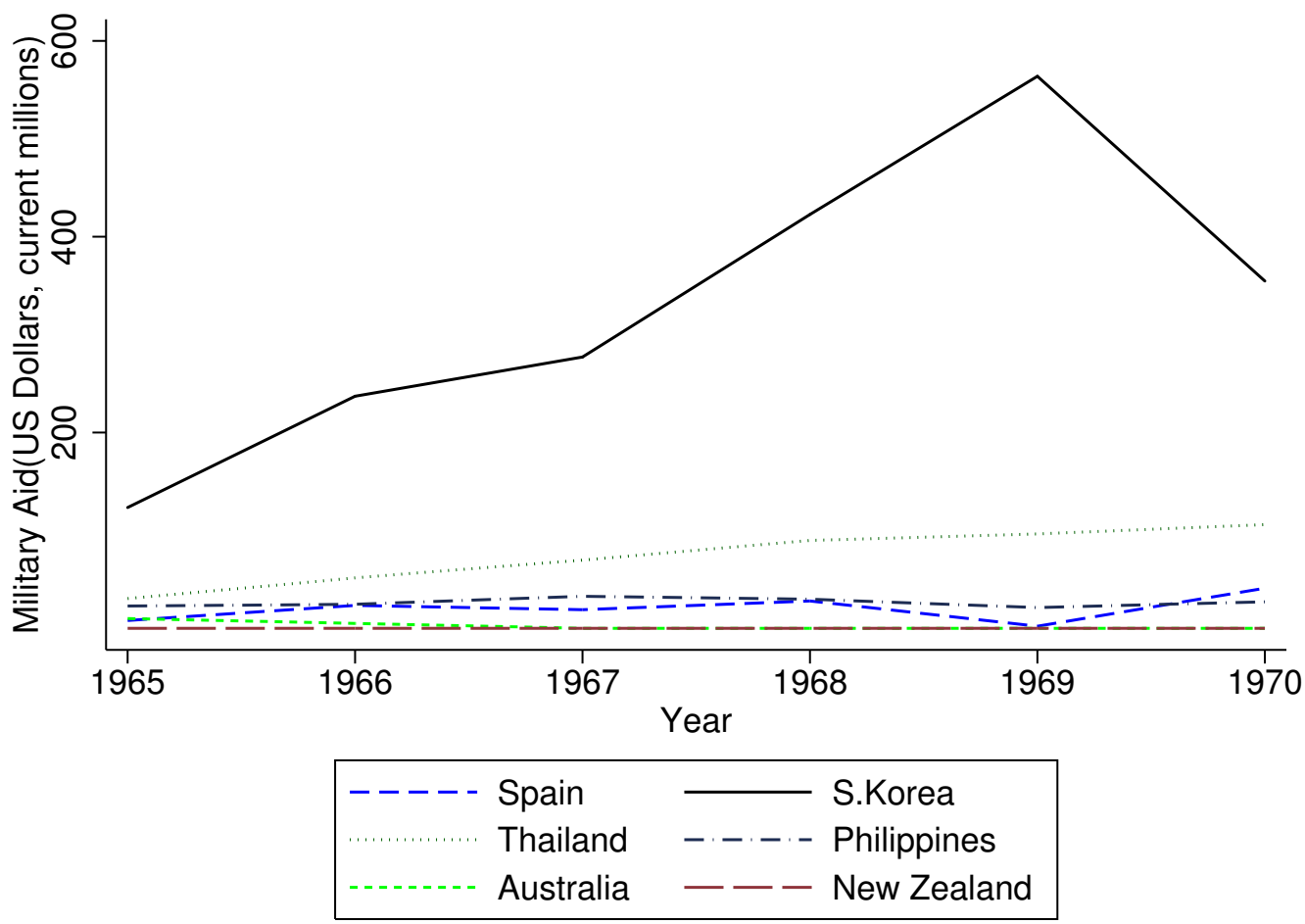

\subsection{Assessing the Impact of IMC Participation on}

\section{Aid}

Are states indeed rewarded for their support of a patron in military endeavors? If so, how long do such rewards last: are benefits temporary or long-lasting? The previous section demonstrated that the use of anecdotal cases lead to erroneous conclusions, and that the 'evidence' proposed by such arguments are problematic.

\subsubsection{Scope}

The analysis focuses on four of the conflicts that the US led an IMC effort in post WWII: the Korean War, Vietnam War, Gulf War, and the Air Campaign 
in Kosovo. While the previous analyses in Chapter 3 also include Afghanistan and Iraq, these are not within the scope of the present analysis due to timeline contamination issues that inhibit the possibility of determining the long term changes of aid. Refer to Chapter 3 for short narratives regarding the conflicts.

\subsubsection{Research Design}

Military Aid The dependent variable is a continuous measure of the change in amounts of military aid received from the US. ${ }^{17}$ The different durations of each war, and the focus on immediate versus enduring effects of IMC participation on aid require that the timeframes within which the changes are to be calculated be adjusted case by case. For instance, setting an arbitrary timeframe of the increase/decrease of military aid received by a state from the US after three years of the start of a war would capture the change in aid amounts at the end of the Korean War (1950-53), less than half-way through Vietnam (1965-73), and two years after the conclusion of the Gulf War(1991) or Kosovo(1999) 18

Due to such concerns, the analysis here directly accounts for the different timeframes of each war, and three different timeframes for each conflict account for the immediate, and mid to long term effects of participation on aid levels.

For the immediate effect, the changes are taken from two years after the start of a conflict for wars that lasted multiple years (i.e., Korea and Vietnam). The variable aid(1) in this instance, is the level of military aid a state received from the US in the first year of a conflict, subtracted from the amount received two years later. For notation purposes, Military Aid $d_{\text {styr }}$ refers to the amount of

\footnotetext{
${ }^{17}$ The original measure from USAID, Greenbook, and in millions of 2012 constant US dollars.

${ }^{18}$ This is one of the problems with Tago (2008), who uses a value of three years for all conflicts in his analysis.
} 
military aid received in the year a conflict started, and Military Aid endyr $_{\text {r }}$ refers to the amount received in the year a conflict ended.

$$
\operatorname{Aid}(1)=\text { Military Aid }_{\text {styr }+2}-\text { MilitaryAid } d_{\text {styr }}
$$

For conflicts that lasted for less than a year (i.e., Gulf and Kosovo), aid(1) refers to the amount received in the previous year subtracted from the amount received in the year of the conflict. In these cases, note that Military Aid ${ }_{s t y r}=$ MilitaryAid endyr. $_{\text {. }}$

$$
\operatorname{Aid}(1)=\text { Military Aid } d_{\text {styr }}-\text { MilitaryAid } d_{\text {styr }-1}
$$

Mid-term effects adjust the timeframe to account for the entirety of the conflict. Accordingly, the variable aid(2) subtracts the amount of aid received in the start year of a conflict, from that of the end year of a conflict. For conflicts that lasted for only one year or less, it is the amount the year before, and after, respectively.

For conflicts spanning multiple years:

$$
\operatorname{Aid}(2)=\text { Military Aid }_{\text {endyr }}-\text { Military Aid }_{\text {styr }}
$$

For conflicts less than a year long:

$$
\operatorname{Aid}(2)=\text { MilitaryAid }_{\text {endyr }+1}-\text { Military Aid }_{\text {styr }-1}
$$

Finally, the long-term effects seek to determine if the act of participation on 
increased rewards outlast the conflict itself. A timeframe of five years after the conclusion of the conflict is selected. The variable aid(3) are the differences of amounts of aid received five years after the conclusion of a conflict, from those amounts at the start year for multiple year conflicts, and from the amounts a year prior to a conflict for those that were shorter than a year ${ }^{19}$

For conflicts spanning multiple years:

$$
\operatorname{Aid}(3)=\text { MilitaryAid } \text { endyr }+5_{5}-\text { Military Aid }_{\text {styr }}
$$

For conflicts less than a year long:

$$
\operatorname{Aid}(3)=\text { MilitaryAid }_{\text {endyr }+5}-\text { Military }_{\text {Aid }} \text { styr-1 }
$$

IMC Participation The main causal variable of interest is whether or not a state participated in a US led IMC. The same binary measure that was constructed by the author for this study is used, and additional information regarding the variable is provided in Chapter 3 .

The only change made is that as opposed to coding states' participation annually, it also codes the necessary subsequent years after its participation to indicate that a state participated (or not) in a previous conflict. For instance, Australia participated in all of the conflicts within the scope of this analysis except the Kosovo Air Campaign. It is accordingly coded as a participant for not only the years that correspond to when it was participating in a conflict, but also those which the analysis focuses on in order to assess the mid and long-term effects. This means that it is also coded positive in 1958(five years

\footnotetext{
${ }^{19}$ The timeframes and specific years for all of the aid variables are provided in Appendix $B$.
} 
after the Korean War), 1978(five years after the US' pullout of Vietnam), and 1996(five years after the Persian Gulf War).

\subsubsection{Methodology}

The data is compiled in panel format, where rows correspond to a specific country-year. An additional term variable, period, is added to account for each conflict. Each country-year observation within the analysis corresponds to one of four periods, with each period accounting for the immediate, mid-term, and long-term effects of participating in a conflict on the dependent variable. For instance, the years 1991, 1992, and 1996 are classified as period 3, corresponding to the years focusing on the Gulf War period.

Three separate OLS regressions are performed, one each for the different timeframes ${ }^{20}$ The long-term effects for the the Kosovo conflict are not estimated, due to the immediate contamination of the effects of the war in Afghanistan in 2001. In addition to the main variable of interest, participation, the analysis includes and controls for the changes in a state's own military expenditures(milex), and its regime affinity and alliance status with the US. ${ }^{21}$ Period fixed effects are added to prevent the pooling of events, and the results can be understood as a between effect for states that participate and don't: the effects for each variable on the changes in military aid.

\footnotetext{
${ }^{20}$ The regressions use the 'regress' command in STATA 12.1, excluding subjects of an IMC, opponents, and those that have constitutional restrictions on the deployment of their military abroad (i.e., Japan).

${ }^{21}$ Timeframes for which the differences in military expenditures are calculated are the same as for military aid, and is in current thousands US dollars (from CoW, National Material Capabilities version 4.0). Regime distance from the US, and alliance status with US, are identical to the variables regime distance(us) and ally, respectively, from Chapter 3 . Unlike the previous logit analyses, the model does not include the material power of a state as a control. While the measure is expected to be highly related to the amount of aid a state receives from the US, the DV in question in this model are not amounts of aid, but the differences. Hence, controlling for changes in military expenditures should suffice.
} 


\subsubsection{Results}

The results of the analyses are presented in Table 5.1. The results correspond to the immediate, mid-term, and long-term models in increasing order. Statistical significance is expressed at the $p<0.05$ level. Results for each period, the constant, and for the military expenditure measures are not included.22

Table 5.1

OLS: Results

\begin{tabular}{lccc}
\hline & $(1)$ & $(2)$ & $(3)$ \\
\hline \hline \multirow{3}{*}{ participant } & & & \\
& $185.789^{*}$ & 24.720 & $-82.986^{*}$ \\
& $(54.094)$ & $(33.536)$ & $(40.288)$ \\
regime distance(us) & -2.104 & -0.242 & -1.755 \\
& $(2.978)$ & $(1.809)$ & $(2.297)$ \\
ally & & & \\
& 0.774 & -26.188 & $-71.301^{*}$ \\
& $(44.422)$ & $(27.268)$ & $(34.404)$
\end{tabular}

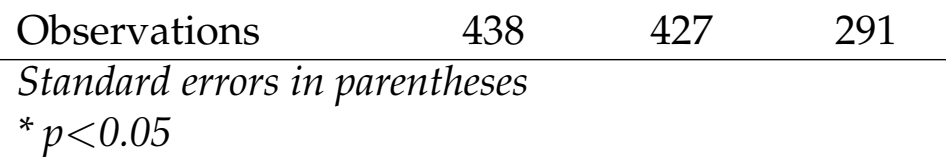

A table featuring the full results are provided in Appendix B (B.11), along with results for models using an alternate specification for the immediate effects for the Vietnam War(B.12), and one that excludes the conflict in Kosovo from the first two models $\mathrm{B} .13,{ }^{23}$ Changing the specifications of the models do not affect any of the implications and have minimal impact on the results.

\footnotetext{
${ }^{22}$ Refer to Table B.11 in Appendix B for a full table that include these figures. The coefficients and standard errors for the military expenditure measures are so small that they are virtually indistinguishable from zero. Nevertheless, the estimates are presented to the necessary decimal points in Table B.11 to show that it is not due to an identification problem.

${ }^{23}$ Thailand started its participation in the Vietnam War in 1967. Hence, the alternate model in Table B.12 adjusts the immediate effect date to 1969.
} 


\subsubsection{Discussion}

Figure 5.5 presents the effect of participation on changes in military aid. Model (1) shows that, after accounting for the other factors in the analysis, IMC participant states indeed witness a relative increase of approximately 185 million dollars in military aid when compared to states that did not do so, supporting H1.

Figure 5.5

Change in Military Aid to Participants

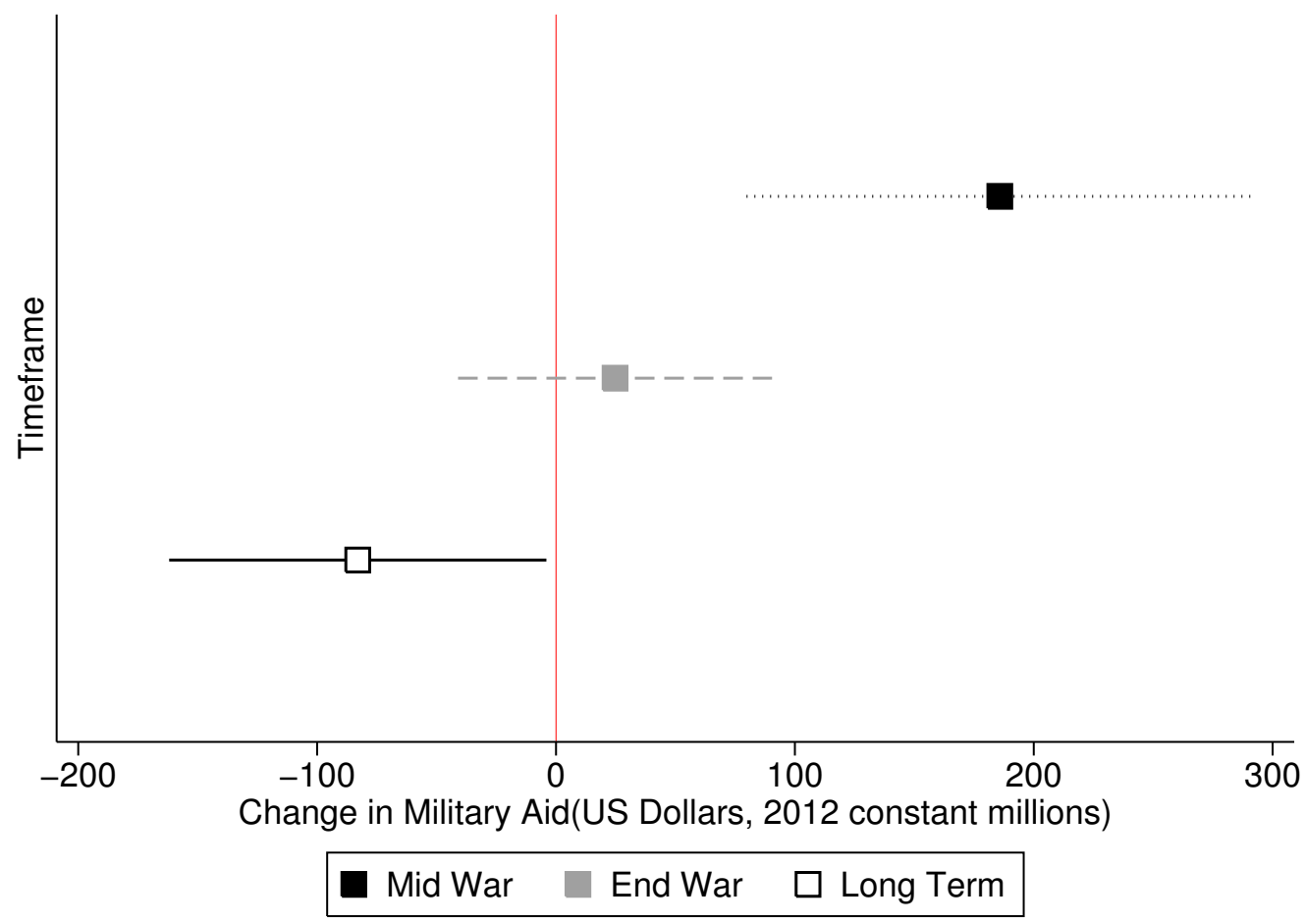

However, when observing the differences at the end of a conflict, the relative increase is drastically reduced to less than 25 million, and even that is not (statistically) significant. This means that there is insufficient evidence to support the notion that by the end of a conflict, those that supported an IMC leading patron should expect to receive more military aid than those that took no action at all. Perhaps more troubling though is that model (3) not only supports $\mathbf{H} \mathbf{2}$, but actually finds the opposite of what some protégés might expect to gain from their 
participation. States that went 'above and beyond' their obligations to the US and helped it in its IMC endeavors found themselves, ceteris paribus, receiving almost 83 million less in military aid several years after the event, than those that decided to sit the same conflict out. It is unlikely that these changes are due to the US diverting aid to other states contributing to follow-up crises, since the five year interval applied to the analysis still provides an ample period before the start of subsequent wars. 24

\subsection{Conclusion}

While the previous chapters argued that states participate in patron led IMCs in an effort to secure and protect benefits, whether or not those expectations are met compose an equally, if not more policy relevant, question. I argued that in terms of aid as a reward for one's participation, states should not expect to have such benefits extend for long periods of time. Due to the politics of inattention expected from patron states, any type of reward should only be temporary, and understood as a patron's response to an immediate and particular challenge.

The analyses of four US led IMC events finds support for this argument, which indicate that when states consider the costs and benefits of participating in IMCs, they should be cautious and nuanced in their expectations regarding the exact benefits to be gained. If such states are satisfied to be payed a substantial sum while their soldiers fight and die in some conflict at the peripheral of their security interests, the decision to do so is valid. However, if the expectation is that the cost of participation will bear fruit and establish a long-lasting aid relationship with a patron, they may be in for a disappointment.

\footnotetext{
${ }^{24}$ e.g., five years after the conclusion of the Korean War leaves seven before the start of Vietnam, and five years after Vietnam leave more than a decade before the Gulf War.
} 


\section{Chapter 6}

\section{Conclusion}

The purpose of this last chapter is first to summarize and review the arguments and findings contained in the previous chapters. In addition to this primary task, it also aims to discuss the contributions of the work, discuss relevant policy implications, and propose possible avenues through which the research program could be continued and expanded. 


\subsection{Dependence, IMC Participation, and its Conse- quences}

Understanding the cause(s) of major wars is undoubtedly an important subject. What propels states to become mired in conflicts with each other is directly related to the security of each. However, the majority of major large-scale wars initially start with a crisis between only two initial belligerents. Many of the states that end up fighting in that war, causing it to balloon into a major conflict, are either those that the war directly infected (e.g., Cambodia and Laos in Vietnam), or others that elected to fight in the conflict in support of one of the initial belligerents. These latter cases include such instances as Ethiopians fighting in the middle of the Korean winter, Italians in the deserts of the Persian Gulf, and Canadians in the highlands of Afghanistan.

In order to understand the contributions of such states, and what caused them to do so, we need to shift our attention away from the conflicts and each contributor's relationship to the initial belligerents, and focus on each of their relationships with the major contributor leading the military coalition effort. This shift paints a drastically different picture, in which each state's level of dependence on that coalition leader shows that states contributing to such causes are more reliant on the leader for economic and security related benefits than non-participants.

Dependence is a state in which one relies on another for specific goods or functions. In this case, a protégé relies on its patron for economic goods (i.e., trade), and for the function of enhanced security the patron provides to itself (i.e., alliance commitments and troops). A highly dependent protégé will use a patron led IMC to secure benefits from its patron into the future, by demonstrating 
its worth and reliability as a protégé by going above and beyond its duty and participating and contributing to its patron's military endeavors.

The theory of dependence leading to war participation proved to explain states' participations in six US-led wars post WWII more consistently and better than either the theories of Balancing Threats or Diffusion of Wars, evidencing the comparative power of the argument and the relevance of its change in focus to the relational aspect between IMC leaders and participants.

While the statistical models provided evidence of the positive association between levels of dependence and the likelihood of IMC participation, the lead up to South Korea's combat participation in the Vietnam War illustrated the two mechanisms through which a state could decide to participate in a patron led war. Situated at a comfortable distance from Vietnam geographically and still quite consumed with a belligerent neighbor and domestic instability, the failure to focus on its relationship to its major patron(i.e., the US) would make explaining Korea's participation quite difficult and confusing.

The added perspective demonstrates a protégé expecting, and actively negotiating, an increase in economic benefits in exchange for its participation, as well as one that is attempting to increase the reliability of its patron's security commitments through its act of good will. On the other hand, the case of Brazil adds the dimension of complicated domestic politics, and shows that despite restrictions, the state still felt burdened to prove its willingness through negotiations as it aimed to gain some concessions from its patron while dangling the carrot of participation in front of it as the main bargaining tool.

Whether or not protégés are rewarded for their participation proves to require more nuance regarding the timeframes of such rewards. The asymmetric nature of patron-protégé relationships and the characteristic 'politics of inattention' of the former actor lead to immediate and temporary rewards, rather than 
the establishment of a long-lasting aid relationship beneficial to the latter. An analysis of the outcomes of four US-led IMCs post-WWII demonstrated that when compared to non-participant states, those that did were indeed given more military aid while participating in US led military coalitions. However, any such increases quickly deteriorated after the conclusion of a conflict.

\subsection{Implications and Areas for Future Research}

The first and foremost point I would want any reader to take away from this project is, at the least, to be able to agree that military coalitions are different from alliances. Military alliances are contingent promises. On the other hand, coalitions are actions, with no uncertainty involved. The theoretical arguments in Chapters 1 and 2 discussed the differences of the two concepts at length. Furthermore, the distinction enabled the analyses in Chapter 3 to use alliances as a factor in predicting states' behavior towards coalitions with persuasive results. Such analyses would not be possible if military coalitions were to be viewed as forms of alliances or subsets thereof.

The argument for how dependence leads to IMC participation also provides a more comprehensive and realist account of war diffusion and protégé behavior than opposing theories. While the Opportunity and Willingness framework originally started with some theoretical arguments on what made states more capable of, and more disposed towards war, it still falls short in explaining why alliances seem to matter for war participation. This leads to conjectures on how having an alliance might hint to an affinity between two states: sharing policy goals and views of the world. In comparison, patron-protégé based dependence theory explains specifically why alliance commitments matter to protégés, and illustrates the mechanism linking alliances to IMC participation. The theory is 
also based on a comparatively more realist foundation, proposing conventional avenues of state to state relations as the driving factors, rather than proposing unmeasurable concepts such as legitimacy and hierarchy as driving war participation.

Several tasks still remain. While it may seem that the end of the Cold War has decreased the importance of alliances as a theoretical and policy related subject of interest in the past two or so decades, I argue that the continuous conflicts that major powers find themselves in, and the increasing difficulties they have in acquiring assistance in such endeavors, require the matter be studied with new found vigor. The spread of terrorism and the introduction of non-state actors does not change the fact that state actors need to address these issues, more often than not, through military coalitions. If the vast differences in defining and understanding alliances posed a problem in the past, I hope that my narrowed focus on military coalitions and starting a theoretical discussion on the phenomena opens the door to further thinking and work on a most urgent and policy related matter.

There are also numerous avenues through which the research could be expanded. First, immediately related to this project, identifying and testing other modes of dependence may prove to shed additional light on the issue. FDI measures are an immediate candidate that was briefly mentioned in my own theorizing, and quantifying trade deals and international organization acceptance patterns may also be possible avenues of further empirical work.

Second, others may find it useful to build on the nascent game model developed in Chapter 2. While the game contained here was intended for pure theoretical verification purposes, expanding the model into a repeated game, and incorporating changing beliefs according to patron behavior, may assist in 
explaining changes in protégé behaviors over time, as well as provide patrons with valuable policy implications regarding their behavior towards protégés.

Third, the idea of dependence could also be applied to international organizations. Do states that are more invested in a certain organization/institution or international order go 'above and beyond' others to follow its rules and/or actions? This avenue of research could possibly help explain the different amount of contributions made to UN peace keeping operations, or states' different levels of compliance with trade and economic related agreements 1$]$

Finally, lopsided dependence between allies and asymmetric partners opens the door to re-examining the role and effectiveness of coercive diplomacy. Be it explicit or implicit, modes of dependence add additional tools of coercion that have previously been overlooked. Using trade, defense treaties, and the positioning of troops as carrots and sticks are all tools available to a patron when trying to persuade a protégé to follow its wishes: agreeing to domestic political and economic reform (e.g., the IMF holding relief loans over the heads of economically failed states), giving up on nuclear proliferation in exchange for extended deterrence (e.g., South Korea and the US) are but two examples.

The policy implications are abundant. The fact that increased trade and other modes of linkage provide an added dimension of coercion for a patron suggest a different mechanism through which a more open and connected world can be advantageous to major powers. It opens another side to the debate over whether or not free trade and increased involvement is beneficial.

The modes of dependence used as a tool of foreign policy and getting a protégé to do a patron's bidding could also possibly help explain the difficulty the US has had with dealing with North Korea's nuclear proliferation, and assist in suggesting a more affective method of solving the problem. The state is by

\footnotetext{
${ }^{1}$ See for instance, Davis (2003).
} 
no means dependent on the US, and hence, the US has had no other alternative but to continue to threaten and sanction the state. Furthermore, as we have witnessed in the past three decades, using enticements fail to bring about a permanent solution. In light of the power of using the modes of dependence as leverage, a more effective and alternative strategy might be to renew efforts to engage China to deal with the problem. While the failed six-party talks did see China take on a larger role than before, the US may need to try harder to persuade China to take the initiative on the issue. North Korea is highly reliant on its northern patron for its economic and political survival, and if China can be convinced that turning those screws can get North Korea to fall in line, some progress may finally be realized.

The arguments and evidence provided here can also provide some guidance to how the US could proceed with building military coalitions more effectively in the future. When that time comes, it may be more effective to identify and focus on those states that are more dependent on itself when seeking cooperation, so that it may avoid a long embarrassing process akin to that of the build up to the 'Coalition of the Willing.'

As for protégé states, when weighing the costs and benefits of IMC participation, it will be beneficial to consider the results of Chapter 6. IMC participation yields immediate benefits, but those benefits are finite. Going out of one's way to fight for the US with expectations of it becoming the start of an aid relationship prove to be unfounded, and unless the immediate benefits outweigh the economic and political costs of sending one's troops abroad, a protégé may find itself with the short end of the stick.

In closing, I leave my readers with some notes regarding the development of this project and the broader implications of such. The main idea of this project, that of how the dependence of protégés on patrons lead them to go above and 
beyond their obligations, is nothing new. It is arguably a conventional wisdom among the collective public minds in most smaller states. I only claim to have attempted to frame this into a more cohesive and testable theory.

We witness dependence influencing one's behavior constantly in our individual lives. The threat of punishment does not necessarily need to be explicit either. Employees fearing that their job is on the line will work harder, going above and beyond their job requirements, in order to secure their positions. Some ambitious employees work harder than others with the expectation of gaining promotions, and in turn, receiving higher pay. The fact that an employee is dependent on his or her employer for their livelihood does not mean they try to reduce that dependence by seeking pay elsewhere.

When discussing the project with my colleagues abroad and those here in the US, I was met with very different responses. Upon hearing the main empirical puzzle that motivates this project, the majority of those from abroad would instantly counter that my puzzle was no puzzle at all. Most of them would argue along the lines of what I have formalized here: that everyone knew that states only went to Korea, Vietnam, or Iraq to derive benefits, or continue deriving benefits, from the US. For example, when framing my research question in light of states' participation in the Korean War, a colleague from Turkey immediately responded that the answer was easy: Turkey fought in Korea to be accepted to NATO. On a similar note, a common term used for the US in private conversations in Korea is 'Big Brother.' This is a term charged with half affection and half disdain: a big brother protects and looks out for his younger siblings, but can also be a bully, wanting and commanding his younger siblings to follow his orders. On the other hand, the majority of those in the US didn't even seem to know that South Korea was the second largest contributor to Vietnam. Such points perhaps evidence a prevailing US centric view of our field, or at the least, 
a major-power oriented approach to security studies that causes our research interests and methods to oversee many other important causes and mechanisms at work. 2

\footnotetext{
${ }^{2}$ Also see Hoffmann (1977), and Walt (2011).
} 
Appendix A

Game Model Additional Resources 


\section{A.1 Parameters}

The relationships between the terms introduced in section 2.4.1 are formalized and presented in Figure A.1.

Figure A.1

Parameters

For all situations

(i-a) $\alpha_{i}=0$ if $\gamma_{j}^{i}>0 \wedge \phi_{j}>0: i$ does not incur any audience costs if it acknowledges $j$ 's non-zero contribution $\phi_{j}$ with some reward $\gamma_{j}^{i}$.

(i-b) $\alpha_{i}=0$ if $\phi_{j}=0: i$ does not need to worry about audience costs for non-contributions, regardless of rewards.

(ii) $\gamma_{j}^{i}<\phi_{j}$ : The rewards from $i$ to $j$ do not exceed the latter's contribution to the war.

(iii) $\alpha_{i}>\gamma_{j}^{i}+\phi_{j}$ : The reputation costs for $i$ 's failure to acknowledge a contribution from $j$ is significantly high so that it is greater than the related rewards and contributions combined.

For no exit cost situations

(iv) $\omega_{j}>0 \Longleftrightarrow \phi_{j}>0 \wedge \gamma_{j}^{i}>0 \wedge \exists \epsilon_{i}$ : Spillover for $j$ is only generated when a) $j$ is a state that can not make $i$ incur exit costs, b) $j$ participates and $\mathrm{c}$ ) is rewarded for its contribution.

(v) $\omega_{j}>\phi_{j}: j$ expects $\omega_{j}$ to exceed the immediate costs of its own participation, $\phi_{j}$.

For exit cost situations

(iv) $\epsilon_{i}>0 \Longleftrightarrow \gamma_{e}^{i}=0\left(\epsilon_{i}=0\right.$ if $\left.\gamma_{e}^{i}>0\right)$ : Exit costs only occur when $i$ stops its relationship with $j$. (If it does not, no exit costs occur.)

(v) $\epsilon_{i}>\gamma_{e}^{i}$ : The cost of continuing the relationship is cheaper than incurring exit costs. 


\section{A.2 Extensive Form Game with Payoffs}

Figures A.2 and A.3 are identical to the games presented in Chapter 2 with the exception to the presentation of the payoffs at the terminal nodes. Unlike the numerical payoffs utilized in Figures 2.6 and 2.7, the games presented here show the actual payoffs at those nodes.

Figure A.2

Participation and Rewards Game: No Exit Costs

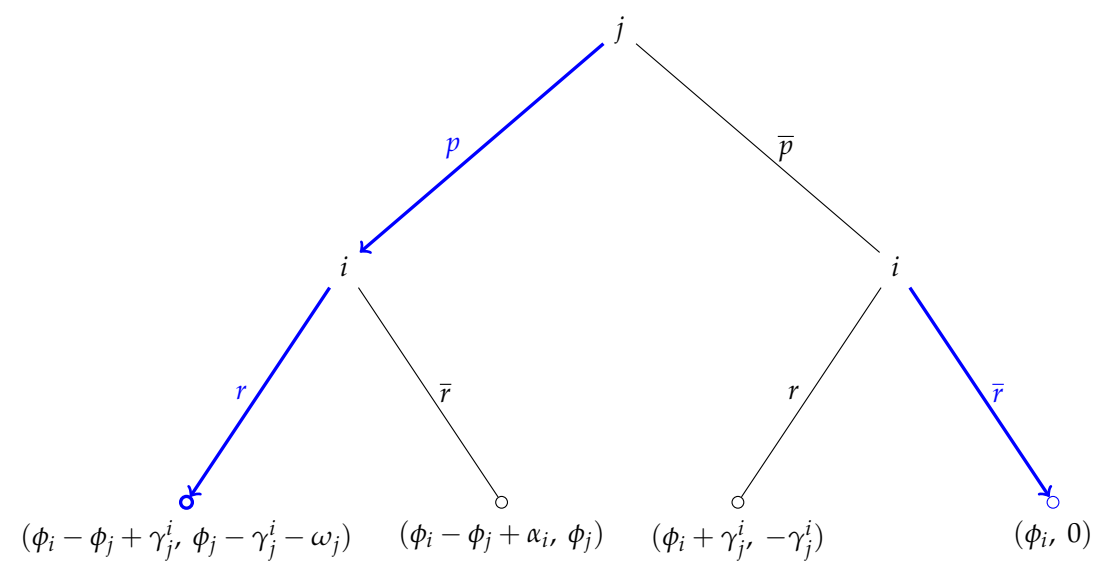

Figure A.3

Participation and Rewards Game: With Exit Costs

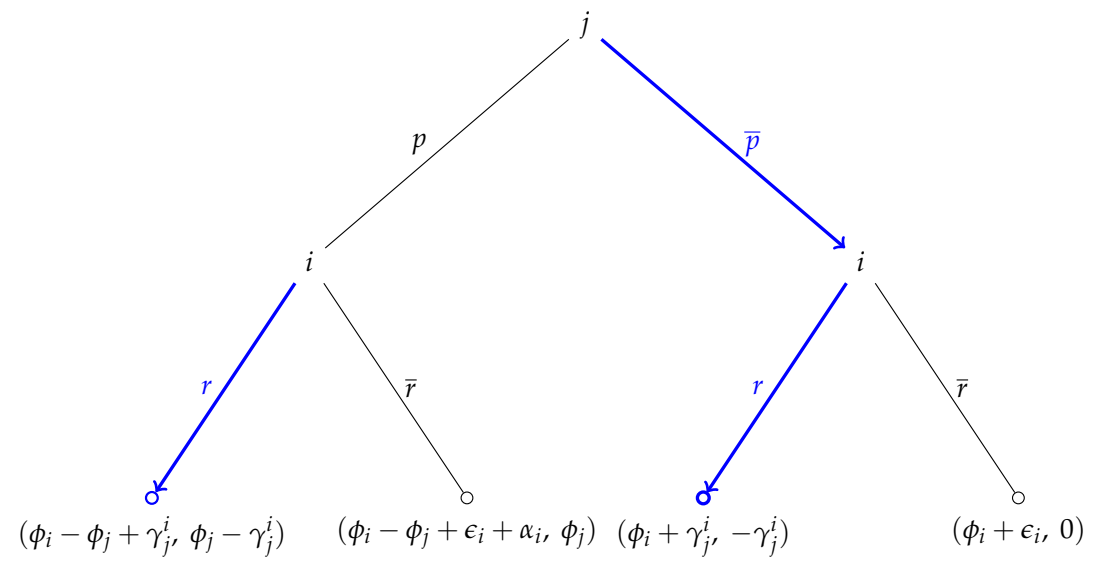




\section{A.3 Mathematical Proof of Ordering the Payoffs}

\section{A.3.1 Payoffs for a Patron with exit costs}

The total cost of war, $\Pi_{i}$, for $i$ is:

$$
\Pi_{i}=\phi_{i}-\phi_{j}+\gamma_{j}^{i}+\epsilon+\alpha_{i}
$$

First, if $\phi_{j}=0$ and $\gamma_{j}^{i}=0$, then according to parameter (i-b), $\alpha_{i}=0$. So the cost of war for the patron is

$$
\begin{aligned}
\Pi_{i} & =\phi_{i}-\phi_{j}+\gamma_{j}^{i}+\epsilon_{i}+\alpha_{i} \\
& =\phi_{i}-0+0+\epsilon_{i}+0 \\
\therefore \Pi_{i} & =\phi_{i}+\epsilon_{i}
\end{aligned}
$$

Second, if $\phi_{j}=0$ and $\gamma_{j}^{i}>0$, then according to parameter (i-b), $\alpha_{i}=0$, and the cost of war for the patron is

$$
\begin{aligned}
\Pi_{i} & =\phi_{i}-\phi_{j}+\gamma_{j}^{i}+\epsilon_{i}+\alpha_{i} \\
& =\phi_{i}-0+\gamma_{j}^{i}+0+0 \\
\therefore \Pi_{i} & =\phi_{i}+\gamma_{j}^{i}
\end{aligned}
$$

Third, if $\phi_{j}>0$ and $\gamma_{j}^{i}=0$, the cost of war for the patron is

$$
\begin{aligned}
\Pi_{i} & =\phi_{i}-\phi_{j}+\gamma_{j}^{i}+\epsilon_{i}+\alpha_{i} \\
& =\phi_{i}-\phi_{j}+0+\epsilon_{i}+\alpha_{i} \\
\therefore \Pi_{i} & =\phi_{i}-\phi_{j}+\epsilon_{i}+\alpha_{i}
\end{aligned}
$$


Finally, if $\phi_{j}>0$ and $\gamma_{j}^{i}>0$, then according to parameter (i-a), $\alpha_{i}=0$, and the cost of war for the patron is

$$
\begin{aligned}
\Pi_{i} & =\phi_{i}-\phi_{j}+\gamma_{j}^{i}+\epsilon_{i}+\alpha_{i} \\
& =\phi_{i}-\phi_{j}+\gamma_{j}^{i}+0+0 \\
\therefore \Pi_{i} & =\phi_{i}-\phi_{j}+\gamma_{j}^{i}
\end{aligned}
$$

We know that $\phi_{i}+\epsilon_{i}<\phi_{i}-\phi_{j}+\epsilon_{i}+\alpha_{i}$ and that $\phi_{i}-\phi_{j}+\gamma_{j}^{i}<\phi_{i}+\gamma_{j}^{i}$. And since $\epsilon>\gamma$, then $\phi_{i}+\gamma_{j}^{i}<\phi_{i}+\epsilon_{i}$. So,

$$
\therefore \phi_{i}-\phi_{j}+\gamma_{j}^{i}<\phi_{i}+\gamma_{j}^{i}<\phi_{i}+\epsilon_{i}<\phi_{i}-\phi_{j}+\epsilon_{i}+\alpha_{i}
$$

Since the patron will seek to minimize its total cost of war, the preference ordering will be from the least costly option to the most costly one. The preferences are ranked from 4 to 1 , with the least costly option designated 4 , and most costly option 1 . These preferences are:

[4] Receive protégé contribution to war and reward $\left(\phi_{j}>0, \gamma_{j}^{i}>0\right)$

[3] Do not receive protégé contribution but still reward $\left(\phi_{j}=0, \gamma_{j}^{i}>0\right)$

[2] Do not receive protégé contribution and not reward $\left(\phi_{j}=0, \gamma_{j}^{i}=0\right)$

[1 ] Receive protégé contribution but do not reward $\left(\phi_{j}>0, \gamma_{j}^{i}=0\right)$

\section{A.3.2 Payoffs for a Patron without exit costs}

The total cost of war, $\Pi_{i}$, for $i$ is:

$$
\Pi_{i}=\phi_{i}-\phi_{j}+\gamma_{j}^{i}+\alpha_{i}
$$


Since $\phi_{j} \geq 0$ and $\gamma_{j}^{i} \geq 0$, there are four possible situations;

- $\phi_{j}=0$ and $\gamma_{j}^{i}=0$

- $\phi_{j}=0$ and $\gamma_{j}^{i}>0$

- $\phi_{j}>0$ and $\gamma_{j}^{i}=0$

- $\phi_{j}>0$ and $\gamma_{j}^{i}>0$

First, if $\phi_{j}=0$ and $\gamma_{j}^{i}=0$, then according to parameter (i-b), $\alpha_{i}=0$. So the cost of war for the patron is

$$
\begin{aligned}
\Pi_{i} & =\phi_{i}-\phi_{j}+\gamma_{j}^{i}+\alpha_{i} \\
& =\phi_{i}-0+0+0 \\
\therefore \Pi_{i} & =\phi_{i}
\end{aligned}
$$

Second, if $\phi_{j}=0$ and $\gamma_{j}^{i}>0$, then according to parameter (i-b), $\alpha_{i}=0$, and the cost of war for the patron is

$$
\begin{aligned}
\Pi_{i} & =\phi_{i}-\phi_{j}+\gamma_{j}^{i}+\alpha_{i} \\
& =\phi_{i}-0+\gamma_{j}^{i}+0 \\
\therefore \Pi_{i} & =\phi_{i}+\gamma_{j}^{i}
\end{aligned}
$$

Third, if $\phi_{j}>0$ and $\gamma_{j}^{i}=0$, the cost of war for the patron is

$$
\begin{aligned}
\Pi_{i} & =\phi_{i}-\phi_{j}+\gamma_{j}^{i}+\alpha_{i} \\
& =\phi_{i}-\phi_{j}+0+\alpha_{i} \\
\therefore \Pi_{i} & =\phi_{i}-\phi_{j}+\alpha_{i}
\end{aligned}
$$


Finally, if $\phi_{j}>0$ and $\gamma_{j}^{i}>0$, then according to parameter (i-a), $\alpha_{i}=0$, and the cost of war for the patron is

$$
\begin{aligned}
\Pi_{i} & =\phi_{i}-\phi_{j}+\gamma_{j}^{i}+\alpha_{i} \\
& =\phi_{i}-\phi_{j}+\gamma_{j}^{i}+0 \\
\therefore \Pi_{i} & =\phi_{i}-\phi_{j}+\gamma_{j}^{i}
\end{aligned}
$$

We now compare the costs, $\Pi_{i}$, from (A.6), (A.7), (A.8), and (A.9) against each other. The first is quite obvious, in that

$$
\phi_{i}+\gamma_{j}^{i}>\phi_{i}
$$

To rank the rest, we draw on our parameters. First, from parameter (ii), we know that $\gamma_{j}^{i}-\phi_{j}<0$. So,

$$
\phi_{i}>\phi_{i}-\phi_{j}+\gamma_{j}^{i}
$$

We also know from parameter (iii) that $\alpha_{i}>\phi_{j}$, which means that $-\phi_{j}+\alpha_{i}>0$. Accordingly, it must be the case that

$$
\phi_{i}-\phi_{j}+\alpha_{i}>\phi_{i}
$$

Finally, parameter (iii) can be re-written as $\gamma_{j}^{i}<-\phi_{j}+\alpha_{i}$. So it must also be the case that

$$
\phi_{i}-\phi_{j}+\alpha_{i}>\phi_{i}+\gamma_{j}^{i}
$$


From (A.10), (A.11), (A.12), and (A.13):

$$
\therefore \phi_{i}-\phi_{j}+\alpha_{i}>\phi_{i}+\gamma_{j}^{i}>\phi_{i}>\phi_{i}-\phi_{j}+\gamma_{j}^{i}
$$

Since the patron will seek to minimize its total cost of war, the preference ordering will be from the least costly option to the most costly one. The preferences are ranked from 4 to 1 , with the least costly option designated 4 , and most costly option 1 . These preferences are:

[4] Receive protégé contribution to war and reward $\left(\phi_{j}>0, \gamma_{j}^{i}>0\right)$

[3] Do not receive protégé contribution and do not reward $\left(\phi_{j}=\gamma_{j}^{i}=0\right)$

[2] Do not receive protégé contribution but reward $\left(\phi_{j}=0, \gamma_{j}^{i}>0\right)$

[1 ] Receive protégé contribution but do not reward $\left(\phi_{j}>0, \gamma_{j}^{i}=0\right)$

\section{A.3.3 Payoffs for a Protégé who poses exit costs for its patron}

The total cost of war, $\Pi_{j}$, for $j$ is:

$$
\Pi_{j}=\phi_{j}-\gamma_{j}^{i}
$$

First, if $\phi_{j}=0$ and $\gamma_{j}^{i}=0$,

$$
\Pi_{j}=0
$$

Second, if $\phi_{j}=0$ and $\gamma_{j}^{i}>0$,

$$
\Pi_{j}=-\gamma_{j}^{i}
$$


Third, if $\phi_{j}>0$ and $\gamma_{j}^{i}=0$,

$$
\Pi_{j}=\phi_{j}
$$

And finally, if $\phi_{j}>0$ and $\gamma_{j}^{i}>0$,

$$
\begin{gathered}
\Pi_{j}=\phi_{j}-\gamma_{j}^{i} \\
\therefore \phi_{j}>\phi_{j}-\gamma_{j}^{i}>0>-\gamma_{j}^{i}
\end{gathered}
$$

Since the protégé will seek to minimize its total cost of war (maximize its profit from war), the preference ordering will be from the least costly option to the most costly one. The preferences are ranked from 4 to 1 , with the least costly option designated 4 , and most costly option 1 . These preferences are:

[4] Not Participate and receive rewards $\left(\phi_{j}=0\right.$ and $\left.\gamma_{j}^{i}>0\right)$

[3 ] Not participate and not receive rewards $\left(\phi_{j}=0\right.$ and $\left.\gamma_{j}^{i}=0\right)$

[2 ] Participate but still receive rewards $\left(\phi_{j}>0\right.$ and $\left.\gamma_{j}^{i}>0\right)$

[1 ] Participate but not be rewarded $\left(\phi_{j}>0\right.$ and $\left.\gamma_{j}^{i}=0\right)$

\section{A.3.4 Payoffs for a Protégé who can not pose exit costs}

The total cost of war, $\Pi_{j}$, for $j$ is:

$$
\Pi_{j}=\phi_{j}-\gamma_{j}^{i}-\omega_{j}
$$

Since $\phi_{j} \geq 0$ and $\gamma_{j}^{i} \geq 0$, there are four possible situations: 
- $\phi_{j}=0$ and $\gamma_{j}^{i}=0$

- $\phi_{j}=0$ and $\gamma_{j}^{i}>0$

- $\phi_{j}>0$ and $\gamma_{j}^{i}=0$

- $\phi_{j}>0$ and $\gamma_{j}^{i}>0$

First, if $\phi_{j}=0$ and $\gamma_{j}^{i}=0$, then according to parameter (iv), $\omega_{j}=0$, and

$$
\begin{aligned}
\Pi_{j} & =\phi_{j}-\gamma_{j}^{i}-\omega_{j} \\
& =0
\end{aligned}
$$

Second, if $\phi_{j}=0$ and $\gamma_{j}^{i}>0$, then according to parameter (iv), $\omega_{j}=0$, and

$$
\Pi_{j}=-\gamma_{j}^{i}
$$

Third, if $\phi_{j}>0$ and $\gamma_{j}^{i}=0$, then according to parameter (iv), $\omega_{j}=0$, and

$$
\Pi_{j}=\phi_{j}
$$

And finally, if $\phi_{j}>0$ and $\gamma_{j}^{i}>0$, then according to parameter (iv), $\omega_{j}>0$, and

$$
\Pi_{j}=\phi_{j}-\gamma_{j}^{i}-\omega_{j}
$$

The first three costs A.20A.21A.22 can be straightforwardly compared to each other:

$$
\phi_{j}>0>-\gamma_{j}^{i}
$$


And, from parameter $(\mathrm{v})$, we know that $\phi_{j}<\omega_{j}$. So $\phi_{j}-\omega_{j}<0$. Which means that

$$
-\gamma_{j}^{i}>-\gamma_{j}^{i}+\phi_{j}-\omega_{j}
$$

So, from (A.24) and (A.25),

$$
\therefore \phi_{j}>0>-\gamma_{j}^{i}>-\gamma_{j}^{i}+\phi_{j}-\omega_{j}
$$

Since the protégé will seek to minimize its total cost of war (maximize its profit from war), the preference ordering will be from the least costly option to the most costly one. The preferences are ranked from 4 to 1, with the least costly option designated 4 , and most costly option 1 . These preferences are:

[4 ] Participate and receive rewards $\left(\phi_{j}>0\right.$ and $\left.\gamma_{j}^{i}>0\right)$

[3 ] Not participate but still receive rewards $\left(\phi_{j}=0\right.$ and $\left.\gamma_{j}^{i}>0\right)$

[2 ] Not participate and not receive rewards $\left(\phi_{j}=0\right.$ and $\left.\gamma_{j}^{i}=0\right)$

[1 ] Participate but not be rewarded $\left(\phi_{j}>0\right.$ and $\left.\gamma_{j}^{i}=0\right)$

\section{A.4 The Game with Reversed Sequence}

Reversing the order in which the actors move does not change the outcome of the game. Refer to the games presented in Figures A.4 and A.5. 
Figure A.4

Participation and Rewards Game: No Exit Costs(reversed)

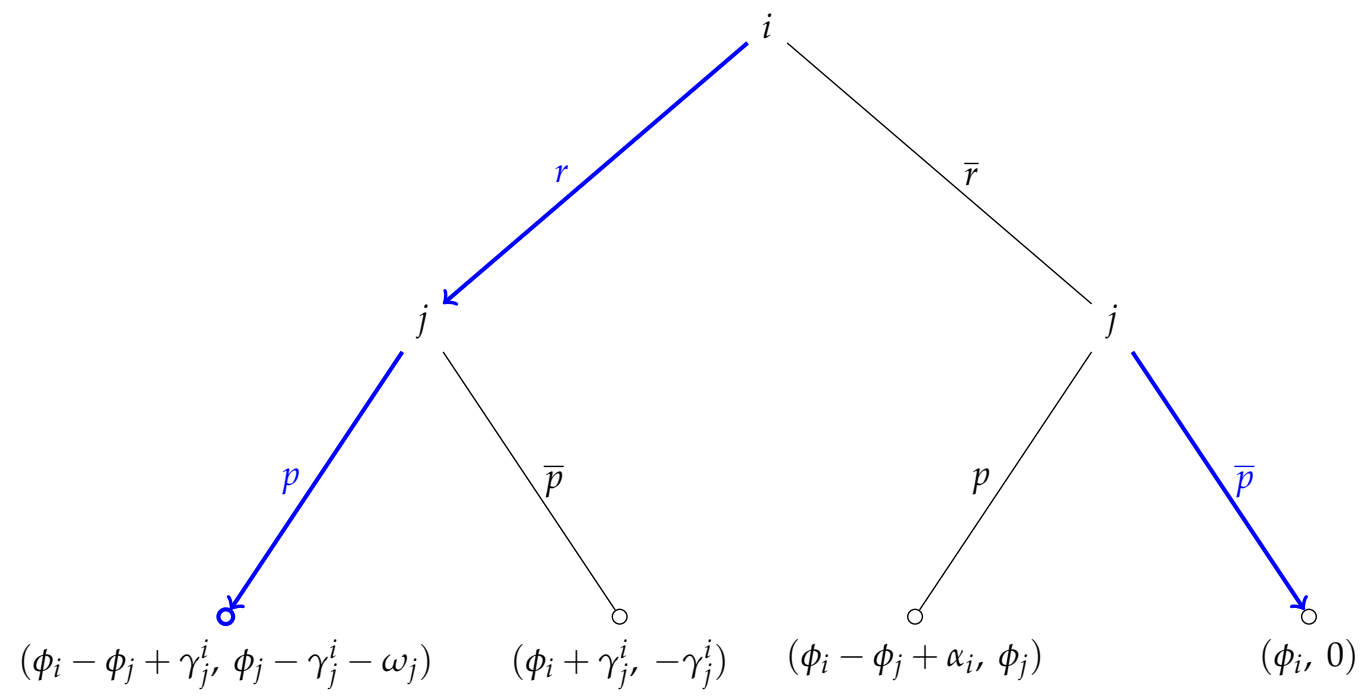

Figure A.5

Participation and Rewards Game: With Exit Costs(reversed)

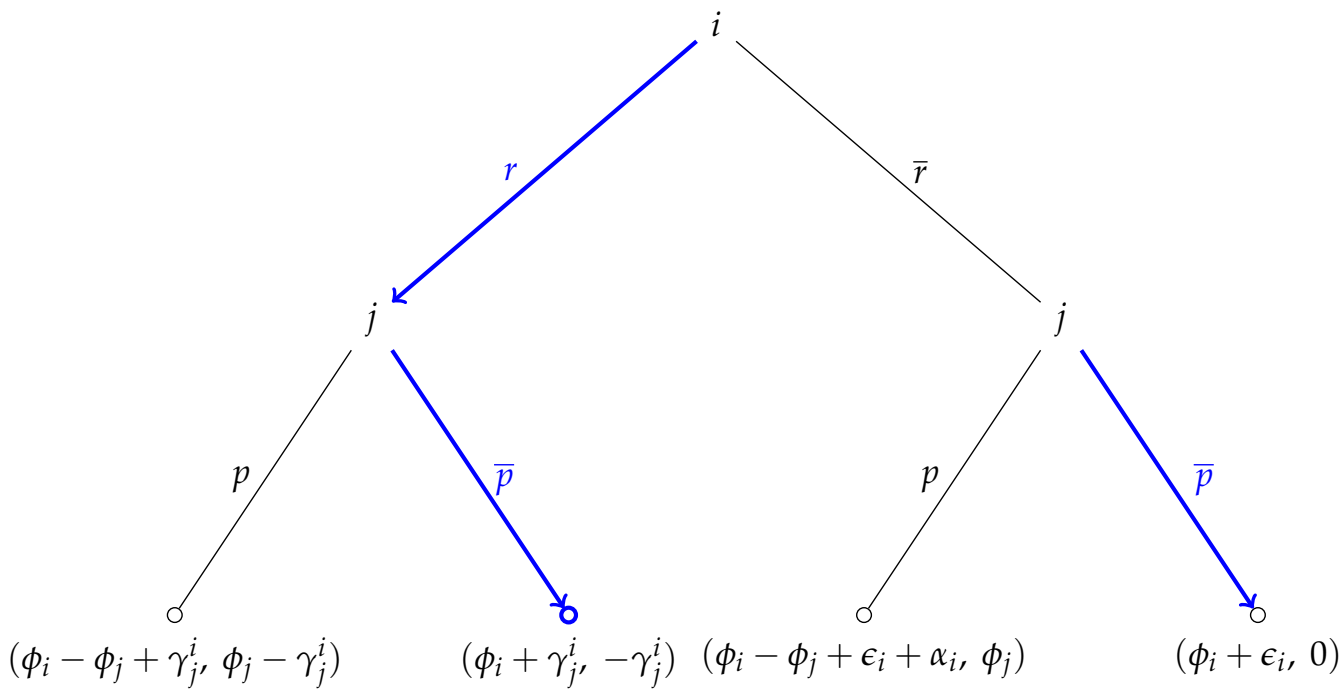


Appendix B

Additional Tables and Figures 


\section{List of Additional Tables and Figures}

1. Table B.1 Sources for IMC Participation Coding (Korean War - Gulf War)

2. Table B.2 Sources for IMC Participation Coding (Kosovo - Iraq)

3. Table B.3. Full Logit Model Results (odds ratios)

4. Table B.4 Full Logit Model Results (coefficients)

5. Table B.5 BoT and O/W Model Marginal Effects

6. Table B.6. Logit with CoW Participate Measure

7. Table B.7 Logit with only Start Years

8. Figure B.1: Distribution of States on Trade Measure

9. Table B.8 Predictive Margins (Trade)

10. Table B.9 Predictive Margins (Troops)

11. Table B.10 Reference Points for Changes in Aid

12. Figure B.2 Changes in Military Aid During Vietnam(Normalized to 1965)

13. Table B.11\} Full OLS Results

14. Table B.12. Alternate OLS(1)

15. Table B.13. Alternate OLS(2)

16. Figure B.3. Military Aid to Participant States (Individual Charts)

17. Figures B.4-B.13 Military Aid to Non-Participant States 


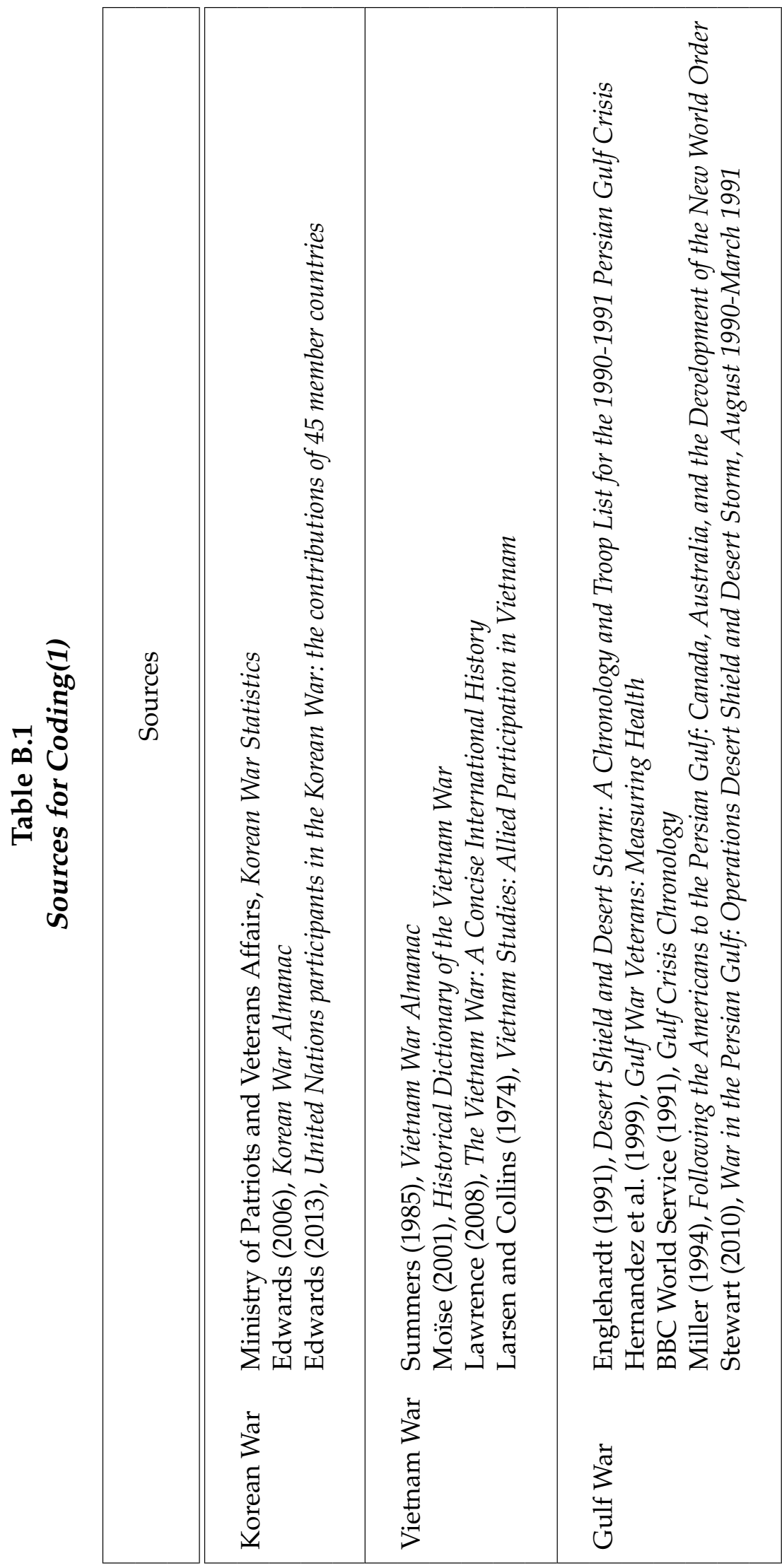




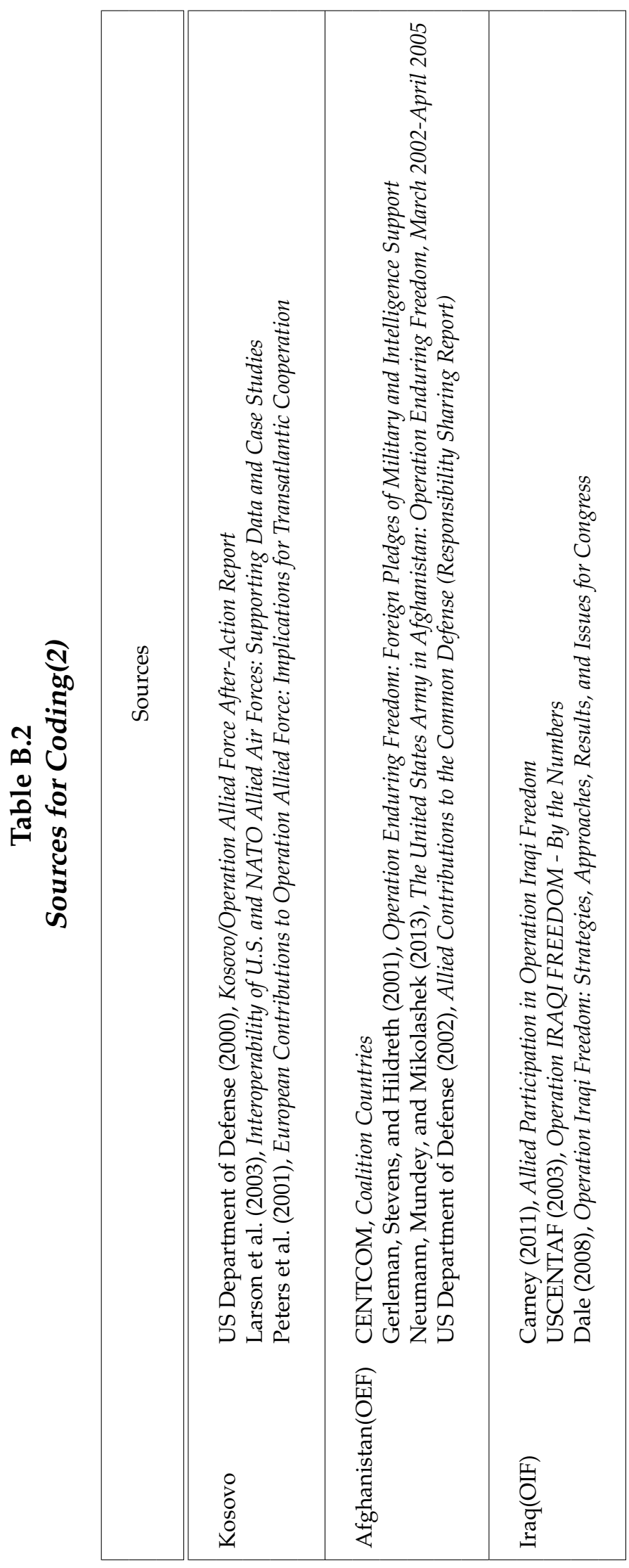


Table B.3

Logit Results: Odds Ratios

\begin{tabular}{|c|c|c|c|c|c|}
\hline & (1) & (2) & (3) & (4) & (5) \\
\hline trade $(\log )$ & & & $\begin{array}{l}1.525^{*} \\
(0.062)\end{array}$ & & $\begin{array}{c}1.294^{*} \\
(0.061)\end{array}$ \\
\hline ally & & & & $\begin{array}{l}11.397^{*} \\
(2.798)\end{array}$ & $\begin{array}{l}6.893^{*} \\
(1.750)\end{array}$ \\
\hline us troops & & & & $\begin{array}{l}2.440^{*} \\
(0.370)\end{array}$ & $\begin{array}{l}2.117^{*} \\
(0.325)\end{array}$ \\
\hline distance & $\begin{array}{l}0.788^{*} \\
(0.019)\end{array}$ & $\begin{array}{l}0.843^{*} \\
(0.022)\end{array}$ & $\begin{array}{l}0.741^{*} \\
(0.019)\end{array}$ & $\begin{array}{l}0.709^{*} \\
(0.022)\end{array}$ & $\begin{array}{c}0.700^{*} \\
(0.022)\end{array}$ \\
\hline regime distance(us) & $\begin{array}{l}0.869^{*} \\
(0.011)\end{array}$ & & $\begin{array}{l}0.945^{*} \\
(0.013)\end{array}$ & $\begin{array}{l}0.920^{*} \\
(0.014)\end{array}$ & $\begin{array}{c}0.950^{*} \\
(0.015)\end{array}$ \\
\hline power(target) & $\begin{array}{c}3.426 \\
(6.144)\end{array}$ & & & & \\
\hline power & $\begin{array}{c}1.037 \\
(0.043)\end{array}$ & $\begin{array}{c}1.063 \\
(0.043)\end{array}$ & $\begin{array}{l}0.780^{*} \\
(0.058)\end{array}$ & $\begin{array}{c}0.936 \\
(0.071)\end{array}$ & $\begin{array}{l}0.763^{*} \\
(0.079)\end{array}$ \\
\hline regime distance(subject) & & $\begin{array}{l}1.063^{*} \\
(0.018)\end{array}$ & & & \\
\hline ally(subject) & & $\begin{array}{l}10.749^{*} \\
(3.657)\end{array}$ & & & \\
\hline oil exporter & & & $\begin{array}{l}0.175^{*} \\
(0.089)\end{array}$ & $\begin{array}{c}0.497 \\
(0.248)\end{array}$ & $\begin{array}{c}0.282^{*} \\
(0.147)\end{array}$ \\
\hline 2.war(Vietnam) & $\begin{array}{l}0.117^{*} \\
(0.050)\end{array}$ & $\begin{array}{l}0.125^{*} \\
(0.056)\end{array}$ & $\begin{array}{l}0.066^{*} \\
(0.016)\end{array}$ & $\begin{array}{l}0.069^{*} \\
(0.019)\end{array}$ & $\begin{array}{l}0.045^{*} \\
(0.013)\end{array}$ \\
\hline 3.war(Gulf) & $\begin{array}{c}0.184 \\
(0.185)\end{array}$ & $\begin{array}{l}0.269^{*} \\
(0.081)\end{array}$ & $\begin{array}{l}0.076^{*} \\
(0.027)\end{array}$ & $\begin{array}{l}0.394^{*} \\
(0.127)\end{array}$ & $\begin{array}{c}0.146^{*} \\
(0.055)\end{array}$ \\
\hline 4.war(Kosovo) & $\begin{array}{l}0.087^{*} \\
(0.034)\end{array}$ & $\begin{array}{l}0.174^{*} \\
(0.056)\end{array}$ & $\begin{array}{l}0.009^{*} \\
(0.004)\end{array}$ & $\begin{array}{l}0.045^{*} \\
(0.020)\end{array}$ & $\begin{array}{c}0.013^{*} \\
(0.007)\end{array}$ \\
\hline 5.war(Afghan) & $\begin{array}{l}0.205^{*} \\
(0.087)\end{array}$ & $\begin{array}{l}0.141^{*} \\
(0.045)\end{array}$ & $\begin{array}{l}0.023^{*} \\
(0.009)\end{array}$ & $\begin{array}{l}0.179^{*} \\
(0.062)\end{array}$ & $\begin{array}{c}0.052^{*} \\
(0.022)\end{array}$ \\
\hline 6.war(Iraq) & $\begin{array}{l}0.143^{*} \\
(0.104)\end{array}$ & $\begin{array}{l}0.205^{*} \\
(0.061)\end{array}$ & $\begin{array}{l}0.037^{*} \\
(0.014)\end{array}$ & $\begin{array}{l}0.242^{*} \\
(0.078)\end{array}$ & $\begin{array}{c}0.075^{*} \\
(0.030)\end{array}$ \\
\hline Constant & $\begin{array}{l}6.106^{*} \\
(3.590)\end{array}$ & $\begin{array}{c}0.985 \\
(0.292)\end{array}$ & $\begin{array}{l}0.000^{*} \\
(0.000)\end{array}$ & $\begin{array}{l}4.931^{*} \\
(1.633)\end{array}$ & $\begin{array}{l}0.007^{*} \\
(0.009)\end{array}$ \\
\hline Observations & 1,999 & 1,024 & 1,904 & 1,842 & 1,788 \\
\hline
\end{tabular}


Table B.4

Logit Results: Coefficients

\begin{tabular}{|c|c|c|c|c|c|}
\hline & (1) & (2) & (3) & (4) & (5) \\
\hline trade(log) & & & $\begin{array}{l}0.422^{*} \\
(0.041)\end{array}$ & & $\begin{array}{c}0.258^{*} \\
(0.047)\end{array}$ \\
\hline ally & & & & $\begin{array}{l}2.433^{*} \\
(0.246)\end{array}$ & $\begin{array}{l}1.931^{*} \\
(0.254)\end{array}$ \\
\hline us troops & & & & $\begin{array}{l}0.892^{*} \\
(0.152)\end{array}$ & $\begin{array}{l}0.750^{*} \\
(0.153)\end{array}$ \\
\hline distance & $\begin{array}{l}-0.239^{*} \\
(0.024)\end{array}$ & $\begin{array}{l}-0.171^{*} \\
(0.026)\end{array}$ & $\begin{array}{l}-0.300^{*} \\
(0.026)\end{array}$ & $\begin{array}{l}-0.343^{*} \\
(0.030)\end{array}$ & $\begin{array}{l}-0.357^{*} \\
(0.031)\end{array}$ \\
\hline regime distance(us) & $\begin{array}{l}-0.141^{*} \\
(0.012)\end{array}$ & & $\begin{array}{l}-0.057^{*} \\
(0.014)\end{array}$ & $\begin{array}{l}-0.084^{*} \\
(0.015)\end{array}$ & $\begin{array}{l}-0.051^{*} \\
(0.016)\end{array}$ \\
\hline power(target) & $\begin{array}{c}1.231 \\
(1.793)\end{array}$ & & & & \\
\hline power & $\begin{array}{c}0.037 \\
(0.042)\end{array}$ & $\begin{array}{c}0.061 \\
(0.040)\end{array}$ & $\begin{array}{l}-0.249^{*} \\
(0.074)\end{array}$ & $\begin{array}{l}-0.066 \\
(0.076)\end{array}$ & $\begin{array}{l}-0.270^{*} \\
(0.104)\end{array}$ \\
\hline regime distance(subject) & & $\begin{array}{l}0.061^{*} \\
(0.017)\end{array}$ & & & \\
\hline ally(subject) & & $\begin{array}{l}2.375^{*} \\
(0.340)\end{array}$ & & & \\
\hline oil exporter & & & $\begin{array}{l}-1.743^{*} \\
(0.510)\end{array}$ & $\begin{array}{c}-0.700 \\
(0.498)\end{array}$ & $\begin{array}{l}-1.266^{*} \\
(0.522)\end{array}$ \\
\hline 2.war(Vietnam) & $\begin{array}{l}-2.148^{*} \\
(0.428)\end{array}$ & $\begin{array}{c}-2.083^{*} \\
(0.449)\end{array}$ & $\begin{array}{c}-2.716^{*} \\
(0.248)\end{array}$ & $\begin{array}{c}-2.675^{*} \\
(0.276)\end{array}$ & $\begin{array}{l}-3.111^{*} \\
(0.292)\end{array}$ \\
\hline 3.war(Gulf) & $\begin{array}{l}-1.692 \\
(1.004)\end{array}$ & $\begin{array}{l}-1.313^{*} \\
(0.303)\end{array}$ & $\begin{array}{c}-2.574^{*} \\
(0.359)\end{array}$ & $\begin{array}{l}-0.933^{*} \\
(0.322)\end{array}$ & $\begin{array}{c}-1.923^{*} \\
(0.377)\end{array}$ \\
\hline 4.war(Kosovo) & $\begin{array}{l}-2.438^{*} \\
(0.384)\end{array}$ & $\begin{array}{l}-1.747^{*} \\
(0.322)\end{array}$ & $\begin{array}{l}-4.687^{*} \\
(0.453)\end{array}$ & $\begin{array}{l}-3.097^{*} \\
(0.436)\end{array}$ & $\begin{array}{l}-4.341^{*} \\
(0.509)\end{array}$ \\
\hline 5.war(Afghan) & $\begin{array}{l}-1.585^{*} \\
(0.425)\end{array}$ & $\begin{array}{l}-1.961^{*} \\
(0.320)\end{array}$ & $\begin{array}{l}-3.789^{*} \\
(0.397)\end{array}$ & $\begin{array}{l}-1.720^{*} \\
(0.348)\end{array}$ & $\begin{array}{l}-2.959^{*} \\
(0.426)\end{array}$ \\
\hline 6.war(Iraq) & $\begin{array}{l}-1.946^{*} \\
(0.727)\end{array}$ & $\begin{array}{l}-1.585^{*} \\
(0.299)\end{array}$ & $\begin{array}{l}-3.303^{*} \\
(0.369)\end{array}$ & $\begin{array}{l}-1.420^{*} \\
(0.325)\end{array}$ & $\begin{array}{l}-2.593^{*} \\
(0.397)\end{array}$ \\
\hline Constant & $\begin{array}{l}1.809^{*} \\
(0.588)\end{array}$ & $\begin{array}{l}-0.015 \\
(0.296)\end{array}$ & $\begin{array}{l}-8.764^{*} \\
(1.082)\end{array}$ & $\begin{array}{l}1.596^{*} \\
(0.331)\end{array}$ & $\begin{array}{l}-4.897^{*} \\
(1.235)\end{array}$ \\
\hline Observations & 1,999 & 1,024 & 1,904 & 1,842 & 1,788 \\
\hline
\end{tabular}


Table B.5

Marginal Effects: BoT and $\mathrm{O} / \mathrm{W}$

\begin{tabular}{|c|c|c|}
\hline & (1) & (2) \\
\hline \multirow[t]{2}{*}{ distance } & -0.019 & -0.022 \\
\hline & $(-0.023 \sim-0.016)$ & $(-0.028 \sim-0.015)$ \\
\hline \multirow[t]{2}{*}{ regime distance(us) } & -0.011 & \\
\hline & $(-0.013 \sim-0.010)$ & \\
\hline \multirow[t]{2}{*}{ power(target) } & 0.099 & \\
\hline & $(-0.184 \sim 0.383)$ & \\
\hline \multirow[t]{2}{*}{ power } & 0.003 & 0.008 \\
\hline & $(-0.004 \sim 0.010)$ & $(-0.002 \sim 0.018)$ \\
\hline \multirow[t]{2}{*}{ regime distance(subject) } & & 0.008 \\
\hline & & $(0.004 \sim 0.012)$ \\
\hline \multirow[t]{2}{*}{ ally(subject) } & & 0.300 \\
\hline & & $(0.222 \sim 0.378)$ \\
\hline Observations & 1,999 & 1,024 \\
\hline
\end{tabular}

marginal effects $\left(\frac{d P(y=1)}{d x}\right)$

95\% confidence intervals in parentheses

marginal effects for war level fixed effects not reported 
Table B.6

Logit with CoW DV Results: Odds Ratios

\begin{tabular}{|c|c|c|c|c|c|}
\hline & $(1)$ & $(2)$ & (3) & $(4)$ & (5) \\
\hline trade $(\log )$ & & & $\begin{array}{l}2.082^{*} \\
(0.168)\end{array}$ & & $\begin{array}{c}1.754^{*} \\
(0.173)\end{array}$ \\
\hline ally & & & & $\begin{array}{l}14.621^{*} \\
(5.370)\end{array}$ & $\begin{array}{l}6.203^{*} \\
(2.328)\end{array}$ \\
\hline us troops & & & & $\begin{array}{l}2.702^{*} \\
(0.392)\end{array}$ & $\begin{array}{l}2.168^{*} \\
(0.310)\end{array}$ \\
\hline distance & $\begin{array}{l}0.726^{*} \\
(0.027)\end{array}$ & $\begin{array}{l}0.857^{*} \\
(0.035)\end{array}$ & $\begin{array}{l}0.652^{*} \\
(0.029)\end{array}$ & $\begin{array}{l}0.686^{*} \\
(0.033)\end{array}$ & $\begin{array}{l}0.656^{*} \\
(0.034)\end{array}$ \\
\hline regime distance(us) & $\begin{array}{c}0.909^{*} \\
(0.015)\end{array}$ & & $\begin{array}{c}1.013 \\
(0.021)\end{array}$ & $\begin{array}{c}0.978 \\
(0.021)\end{array}$ & $\begin{array}{c}1.020 \\
(0.025)\end{array}$ \\
\hline power(target) & $\begin{array}{c}14.897 \\
(33.091)\end{array}$ & & & & \\
\hline power & $\begin{array}{c}1.054 \\
(0.049)\end{array}$ & $\begin{array}{c}1.099 \\
(0.054)\end{array}$ & $\begin{array}{l}0.794^{*} \\
(0.075)\end{array}$ & $\begin{array}{c}1.001 \\
(0.087)\end{array}$ & $\begin{array}{c}0.727^{*} \\
(0.114)\end{array}$ \\
\hline regime distance(subject) & & $\begin{array}{l}1.095^{*} \\
(0.034)\end{array}$ & & & \\
\hline ally(subject) & & $\begin{array}{l}50.077^{*} \\
(35.253)\end{array}$ & & & \\
\hline oil exporter & & & $\begin{array}{c}0.425 \\
(0.265)\end{array}$ & $\begin{array}{c}1.905 \\
(1.156)\end{array}$ & $\begin{array}{c}0.947 \\
(0.627)\end{array}$ \\
\hline Observations & 1,999 & 1,024 & 1,904 & 1,842 & 1,788 \\
\hline
\end{tabular}


Table B.7

Logit with only Start Years: Odds Ratios

\begin{tabular}{|c|c|c|c|c|c|}
\hline & (1) & (2) & (3) & (4) & (5) \\
\hline trade(log) & & & $\begin{array}{c}1.300^{*} \\
(0.061)\end{array}$ & & $\begin{array}{c}1.158^{*} \\
(0.062)\end{array}$ \\
\hline ally & & & & $\begin{array}{l}8.789^{*} \\
(2.960)\end{array}$ & $\begin{array}{l}6.457^{*} \\
(2.245)\end{array}$ \\
\hline us troops & & & & $\begin{array}{l}1.577^{*} \\
(0.349)\end{array}$ & $\begin{array}{c}1.416 \\
(0.309)\end{array}$ \\
\hline distance & $\begin{array}{c}0.810^{*} \\
(0.028)\end{array}$ & $\begin{array}{l}0.823^{*} \\
(0.028)\end{array}$ & $\begin{array}{l}0.776^{*} \\
(0.029)\end{array}$ & $\begin{array}{l}0.719^{*} \\
(0.030)\end{array}$ & $\begin{array}{c}0.715^{*} \\
(0.030)\end{array}$ \\
\hline regime distance(us) & $\begin{array}{c}0.825^{*} \\
(0.018)\end{array}$ & & $\begin{array}{c}0.878^{*} \\
(0.022)\end{array}$ & $\begin{array}{c}0.878^{*} \\
(0.022)\end{array}$ & $\begin{array}{c}0.902^{*} \\
(0.023)\end{array}$ \\
\hline power(target) & $\begin{array}{c}0.126 \\
(0.138)\end{array}$ & & & & \\
\hline power & $\begin{array}{c}1.109 \\
(0.073)\end{array}$ & $\begin{array}{c}1.093 \\
(0.060)\end{array}$ & $\begin{array}{c}0.880 \\
(0.086)\end{array}$ & $\begin{array}{c}1.010 \\
(0.094)\end{array}$ & $\begin{array}{c}0.894 \\
(0.101)\end{array}$ \\
\hline regime distance(subject) & & $\begin{array}{c}0.993 \\
(0.020)\end{array}$ & & & \\
\hline ally(subject) & & $\begin{array}{l}6.422^{*} \\
(2.199)\end{array}$ & & & \\
\hline oil exporter & & & $\begin{array}{c}0.585 \\
(0.319)\end{array}$ & $\begin{array}{c}0.942 \\
(0.501)\end{array}$ & $\begin{array}{c}0.666 \\
(0.367)\end{array}$ \\
\hline Observations & 796 & 681 & 773 & 733 & 723 \\
\hline
\end{tabular}




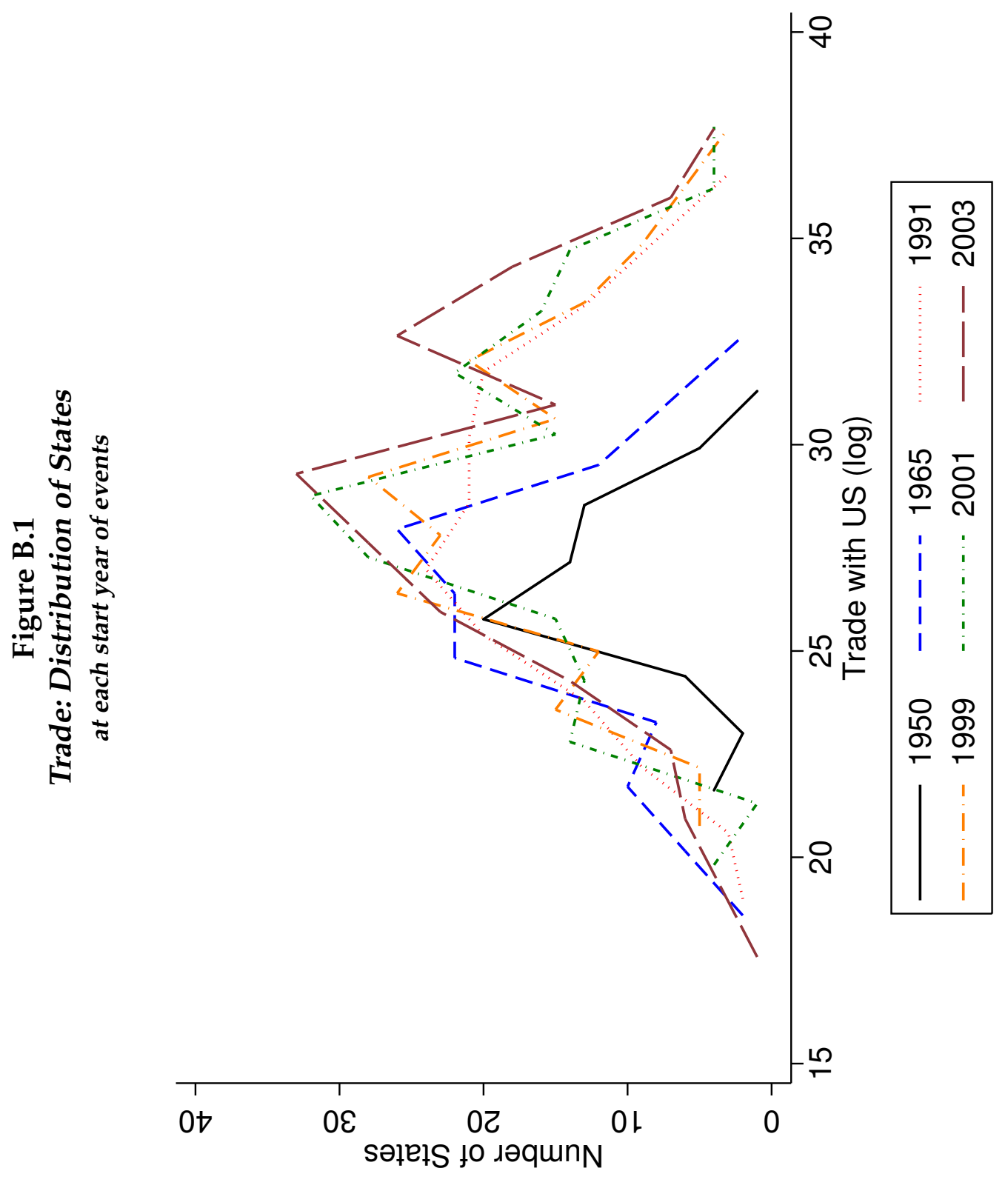


Table B.8

Trade(logged): Predictive Margins of Participation

\begin{tabular}{lcc}
\hline & margin & ci \\
\hline \hline & & \\
17 & 0.002 & $(0.000 \sim 0.004)$ \\
18 & 0.003 & $(0.001 \sim 0.005)$ \\
19 & 0.004 & $(0.001 \sim 0.007)$ \\
20 & 0.006 & $(0.002 \sim 0.011)$ \\
21 & 0.010 & $(0.004 \sim 0.015)$ \\
22 & 0.014 & $(0.008 \sim 0.021)$ \\
23 & 0.021 & $(0.013 \sim 0.029)$ \\
24 & 0.030 & $(0.020 \sim 0.039)$ \\
25 & 0.042 & $(0.031 \sim 0.053)$ \\
26 & 0.058 & $(0.046 \sim 0.070)$ \\
27 & 0.079 & $(0.067 \sim 0.092)$ \\
28 & 0.106 & $(0.093 \sim 0.119)$ \\
29 & 0.139 & $(0.123 \sim 0.155)$ \\
30 & 0.179 & $(0.158 \sim 0.201)$ \\
31 & 0.227 & $(0.197 \sim 0.257)$ \\
32 & 0.281 & $(0.240 \sim 0.323)$ \\
33 & 0.342 & $(0.287 \sim 0.397)$ \\
34 & 0.408 & $(0.338 \sim 0.477)$ \\
35 & 0.476 & $(0.393 \sim 0.559)$ \\
36 & 0.545 & $(0.451 \sim 0.639)$ \\
37 & 0.613 & $(0.511 \sim 0.714)$ \\
38 & 0.676 & $(0.570 \sim 0.782)$
\end{tabular}

Observations $\quad 1,904$

ci in parentheses 
Table B.9

Troops: Predictive Margins of Participation

\begin{tabular}{lrc}
\hline & margin & ci \\
\hline \hline & & \\
2 & 0.108 & $(0.096 \sim 0.121)$ \\
4 & 0.271 & $(0.204 \sim 0.337)$ \\
6 & 0.499 & $(0.347 \sim 0.651)$ \\
8 & 0.728 & $(0.518 \sim 0.938)$ \\
10 & 0.903 & $(0.741 \sim 1.066)$ \\
12 & 0.978 & $(0.919 \sim 1.037)$ \\
14 & 0.996 & $(0.982 \sim 1.010)$ \\
16 & 0.999 & $(0.997 \sim 1.002)$ \\
18 & 1.000 & $(0.999 \sim 1.000)$ \\
20 & 1.000 & $(1.000 \sim 1.000)^{*}$ \\
\multicolumn{3}{l}{ Observations } \\
ci in parentheses & 1,842 & \\
$*$ & \\
$*$ *. 9998802 $\sim 1.000082$ & \\
*.999978 1.000016 &
\end{tabular}

Table B.10

Reference Points for Changes in Aid

\begin{tabular}{lcccccccc}
\hline & Korean & \multicolumn{2}{c}{ Vietnam } & \multicolumn{2}{c}{ Gulf } & \multicolumn{2}{c}{ Kosovo } \\
\hline \hline & & & & & & & \\
Aid(1) & 1952 & 1950 & $1967(9)^{*}$ & 1965 & 1991 & 1990 & 1999 & 1998 \\
Aid(2) & 1953 & 1950 & 1973 & 1965 & 1992 & 1990 & 2000 & 1998 \\
Aid(3) & 1958 & 1950 & 1978 & 1965 & 1996 & 1990 & $\mathrm{n} / \mathrm{a}$ \\
\hline$*$ *1969 for OLS(a) in Table & B.13 & to account for Thailand's late participation.
\end{tabular}


Figure B.2

\section{Changes in Military Aid During Vietnam}

percentage change from 1965

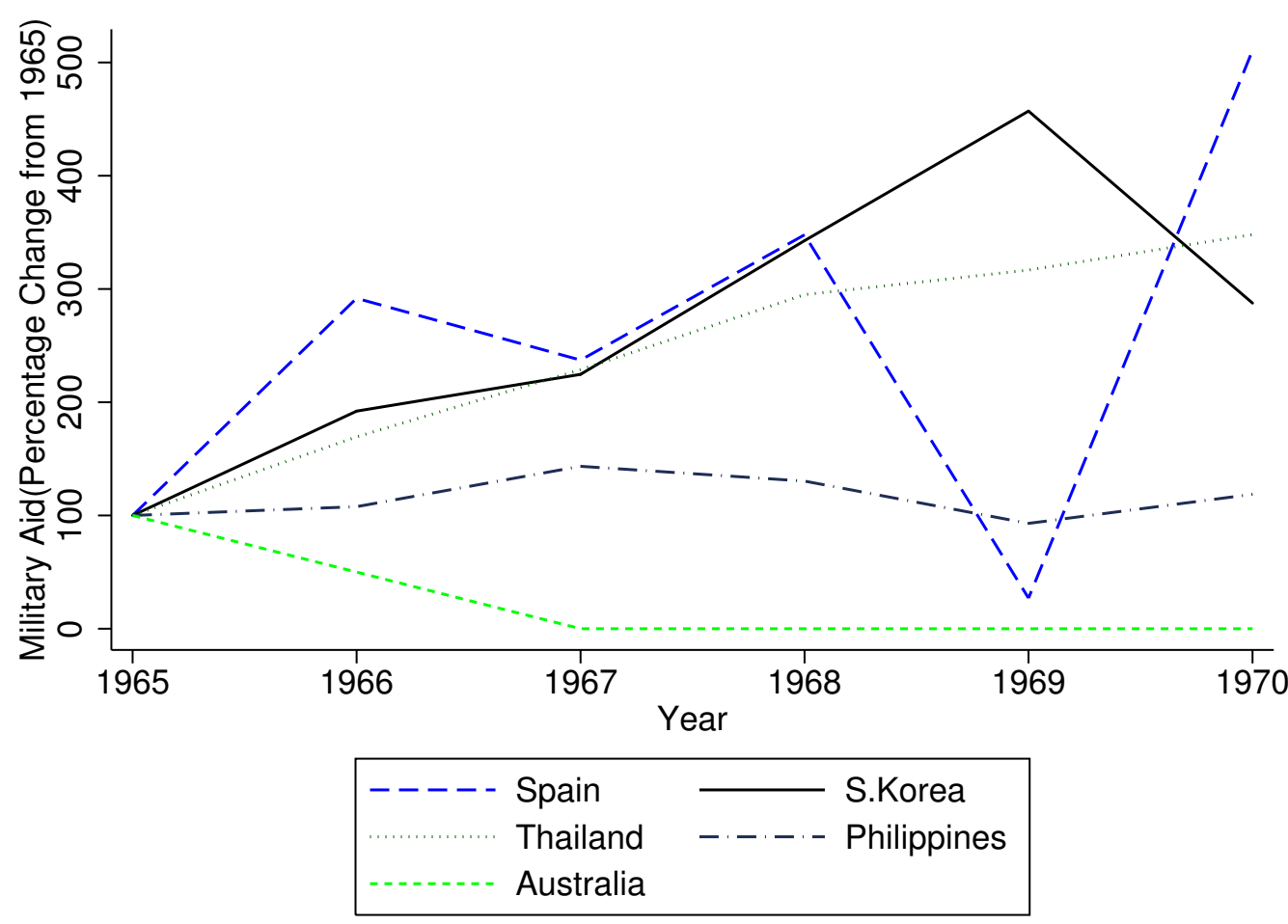

*New Zealand Excluded

: The state did not receive any aid throughout the scope 
Table B.11

Full OLS Results

\begin{tabular}{|c|c|c|c|}
\hline & (1) & (2) & (3) \\
\hline participant & $\begin{array}{l}185.789 * \\
(54.094)\end{array}$ & $\begin{array}{c}24.720 \\
(33.536)\end{array}$ & $\begin{array}{c}-82.986^{*} \\
(40.288)\end{array}$ \\
\hline regime distance(us) & $\begin{array}{l}-2.104 \\
(2.978)\end{array}$ & $\begin{array}{c}-0.242 \\
(1.809)\end{array}$ & $\begin{array}{l}-1.755 \\
(2.297)\end{array}$ \\
\hline ally & $\begin{array}{c}0.774 \\
(44.422)\end{array}$ & $\begin{array}{l}-26.188 \\
(27.268)\end{array}$ & $\begin{array}{l}-71.301^{*} \\
(34.404)\end{array}$ \\
\hline $\operatorname{milex}(1)$ & $\begin{array}{c}0.000018 \\
(0.000016)\end{array}$ & & \\
\hline milex(2) & & $\begin{array}{l}-0.000001 \\
(0.000002)\end{array}$ & \\
\hline milex(3) & & & $\begin{array}{c}-0.000001 \\
(0.000002)\end{array}$ \\
\hline 2.period(Vietnam) & $\begin{array}{c}-274.560^{*} \\
(61.330)\end{array}$ & $\begin{array}{l}-69.400 \\
(38.342)\end{array}$ & $\begin{array}{c}23.741 \\
(41.693)\end{array}$ \\
\hline 3.period(Gulf) & $\begin{array}{c}-345.183^{*} \\
(60.401)\end{array}$ & $\begin{array}{c}-116.276^{*} \\
(38.443)\end{array}$ & $\begin{array}{c}-2.041 \\
(41.143)\end{array}$ \\
\hline 4.period(Kosovo) & $\begin{array}{c}-309.795^{*} \\
(59.777)\end{array}$ & $\begin{array}{l}-94.327^{*} \\
(37.297)\end{array}$ & \\
\hline Constant & $\begin{array}{c}306.135^{*} \\
(66.670)\end{array}$ & $\begin{array}{l}109.165^{*} \\
(41.123)\end{array}$ & $\begin{array}{c}43.032 \\
(48.483)\end{array}$ \\
\hline Observations & 438 & 427 & 291 \\
\hline
\end{tabular}

standard errors in parentheses

* $p<0.05$ 
Table B.12

Alternate OLS(a)

: immediate effect in Vietnam set to 1969 to account for Thailand

\begin{tabular}{lccc}
\hline & $(1)$ & $(2)$ & $(3)$ \\
\hline \hline & & & \\
participant & $175.187^{*}$ & 24.720 & $-82.986^{*}$ \\
& $(67.668)$ & $(33.536)$ & $(40.288)$ \\
regime distance(us) & -4.314 & -0.242 & -1.755 \\
& $(4.095)$ & $(1.809)$ & $(2.297)$ \\
ally & & & \\
& -0.957 & -26.188 & $-71.301^{*}$ \\
2.period & $(59.974)$ & $(27.268)$ & $(34.404)$ \\
& & & \\
3.period & & -69.400 & 23.741 \\
& & $(38.342)$ & $(41.693)$ \\
4.period & $-348.525^{*}$ & $-116.276^{*}$ & -2.041 \\
& $(69.560)$ & $(38.443)$ & $(41.143)$ \\
Constant & $-316.055^{*}$ & $-94.327^{*}$ & \\
& $(69.363)$ & $(37.297)$ & \\
& $330.019^{*}$ & $109.165^{*}$ & 43.032 \\
& $(83.217)$ & $(41.123)$ & $(48.483)$
\end{tabular}

$\begin{array}{llll}\text { Observations } & 327 & 427 & 291\end{array}$

standard errors in parentheses

* $p<0.05$

milex estimates not reported 
Table B.13

Alternate $\mathrm{OLS}(\mathrm{b})$

: Kosovo not included

\begin{tabular}{lccc}
\hline & $(1)$ & $(2)$ & $(3)$ \\
\hline \hline \multirow{2}{*}{ participant } & & & \\
& $248.441^{*}$ & 36.721 & $-82.986^{*}$ \\
& $(76.053)$ & $(45.690)$ & $(40.288)$ \\
regime distance(us) & -2.776 & 0.659 & -1.755 \\
& $(4.351)$ & $(2.566)$ & $(2.297)$ \\
ally & & & \\
& 22.060 & -22.568 & $-71.301^{*}$ \\
2.period & $(64.632)$ & $(38.679)$ & $(34.404)$ \\
& & & \\
3.period & $-254.952^{*}$ & -68.809 & 23.741 \\
& $(76.008)$ & $(46.495)$ & $(41.693)$ \\
Constant & $-338.085^{*}$ & $-113.565^{*}$ & -2.041 \\
& $(74.757)$ & $(46.452)$ & $(41.143)$ \\
& $283.422^{*}$ & 95.279 & 43.032 \\
& $(89.992)$ & $(53.758)$ & $(48.483)$
\end{tabular}

$\begin{array}{llll}\text { Observations } & 287 & 276 & 291\end{array}$

standard errors in parentheses

${ }^{*} p<0.05$

milex estimates not reported 
Figure B.3

Military Aid to Participant Countries

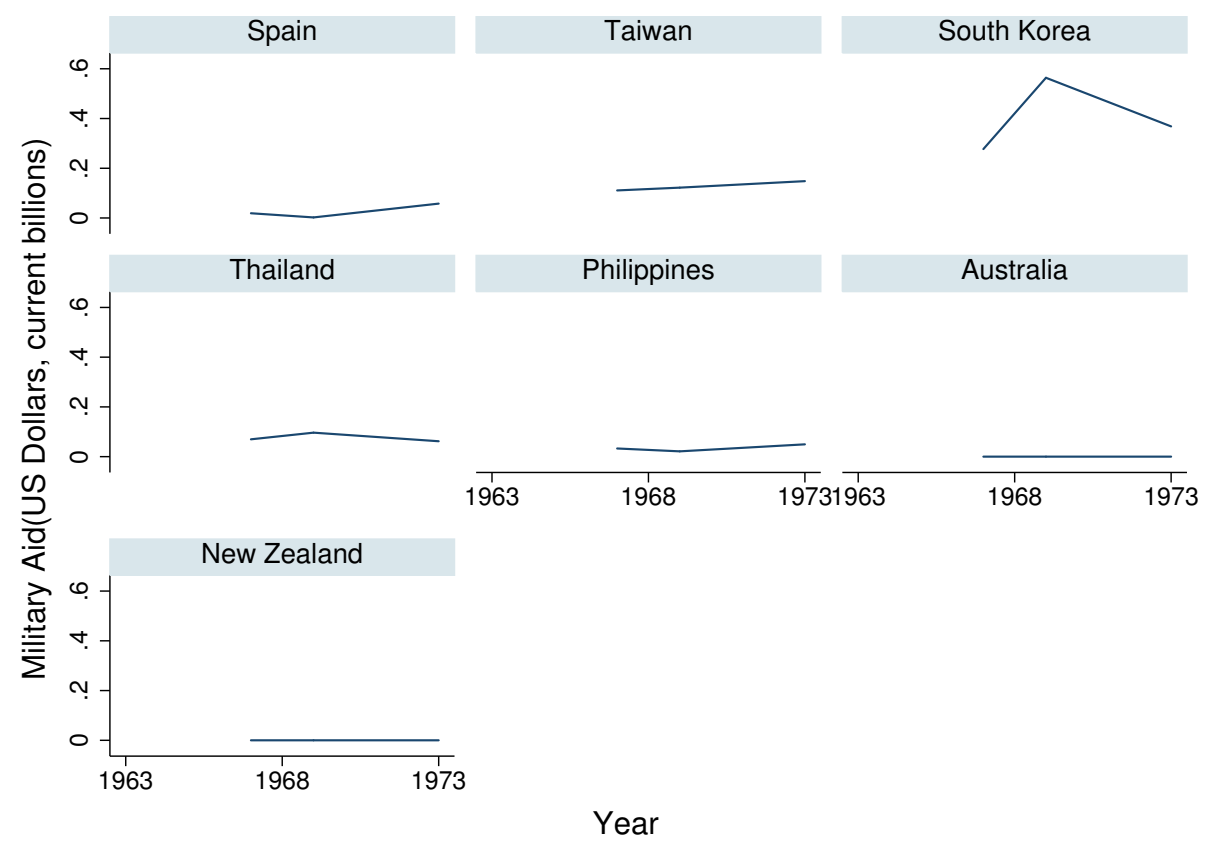

Figure B.4

Military Aid to Non-Participant Countries

1 of 10

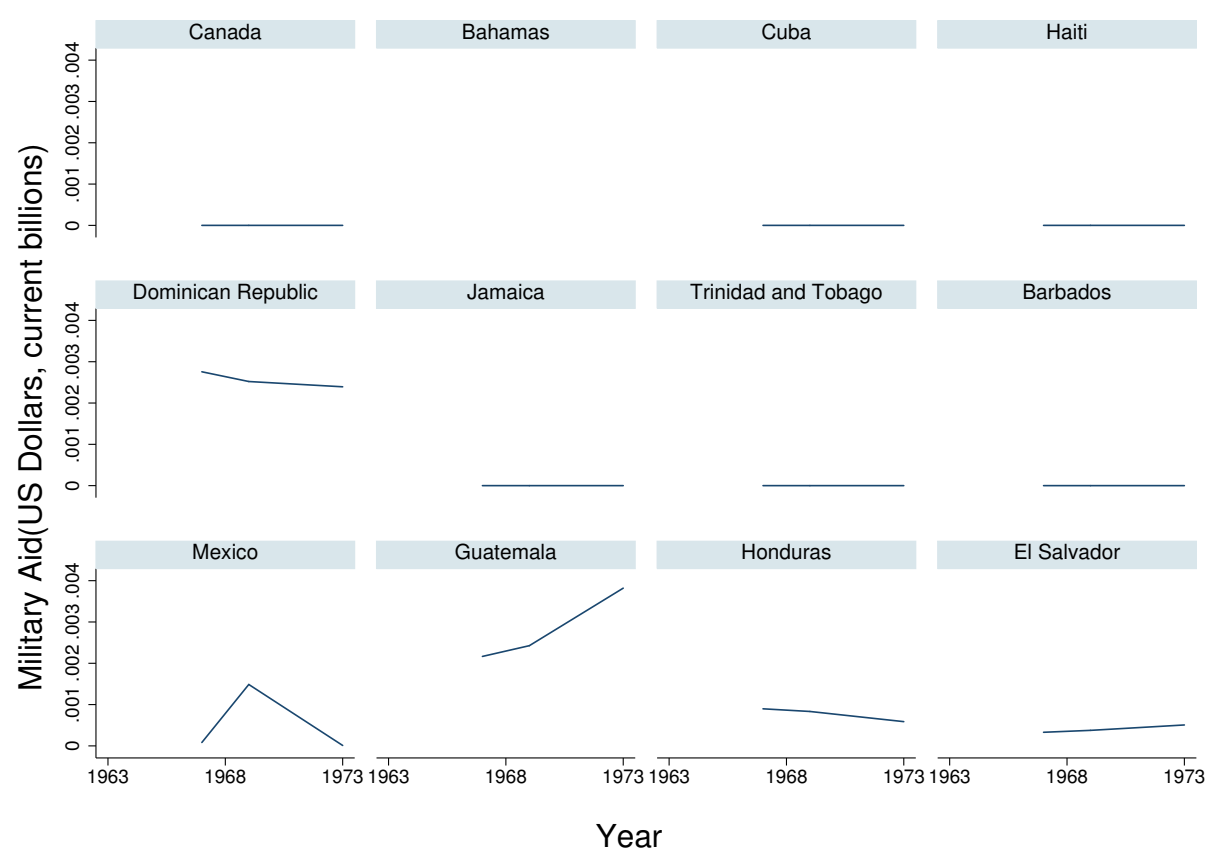


Figure B.5

Military Aid to Non-Participant Countries 2 of 10

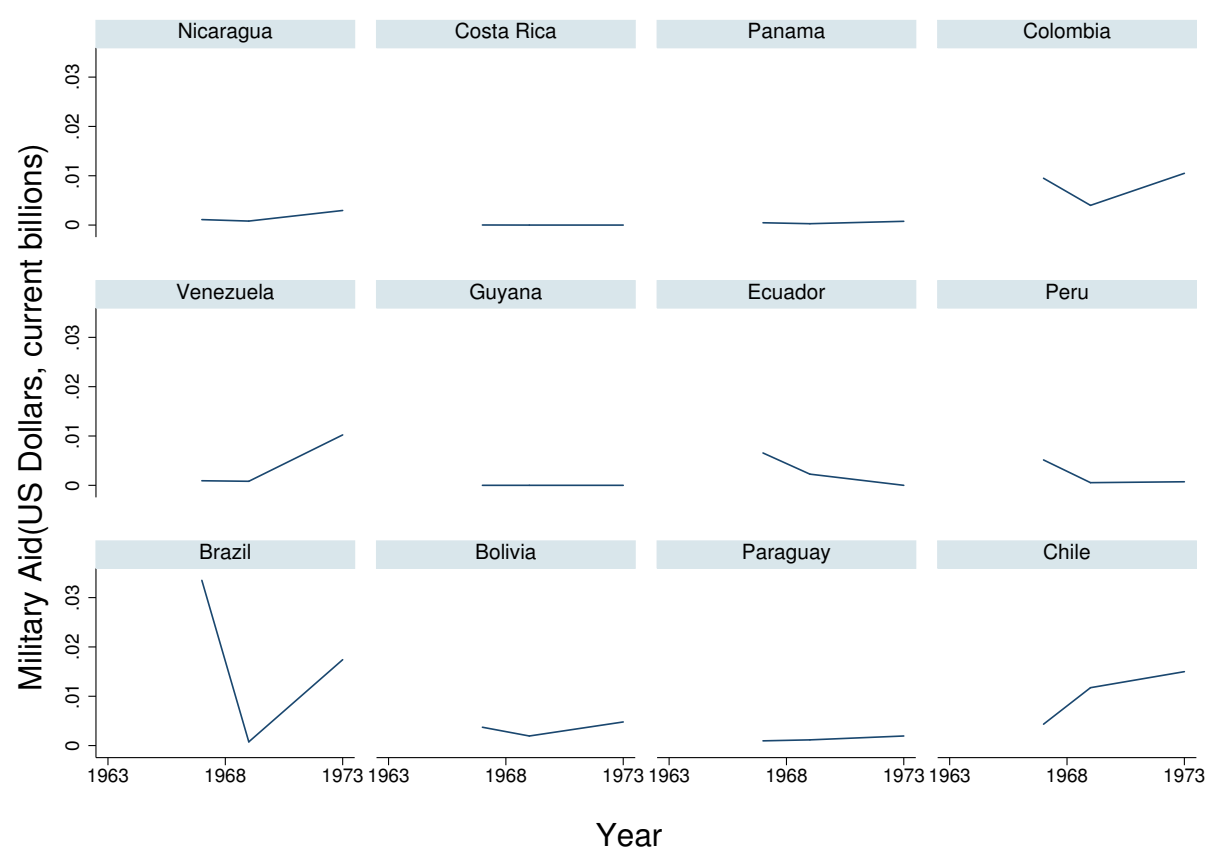

Figure B.6

Military Aid to Non-Participant Countries 3 of 10

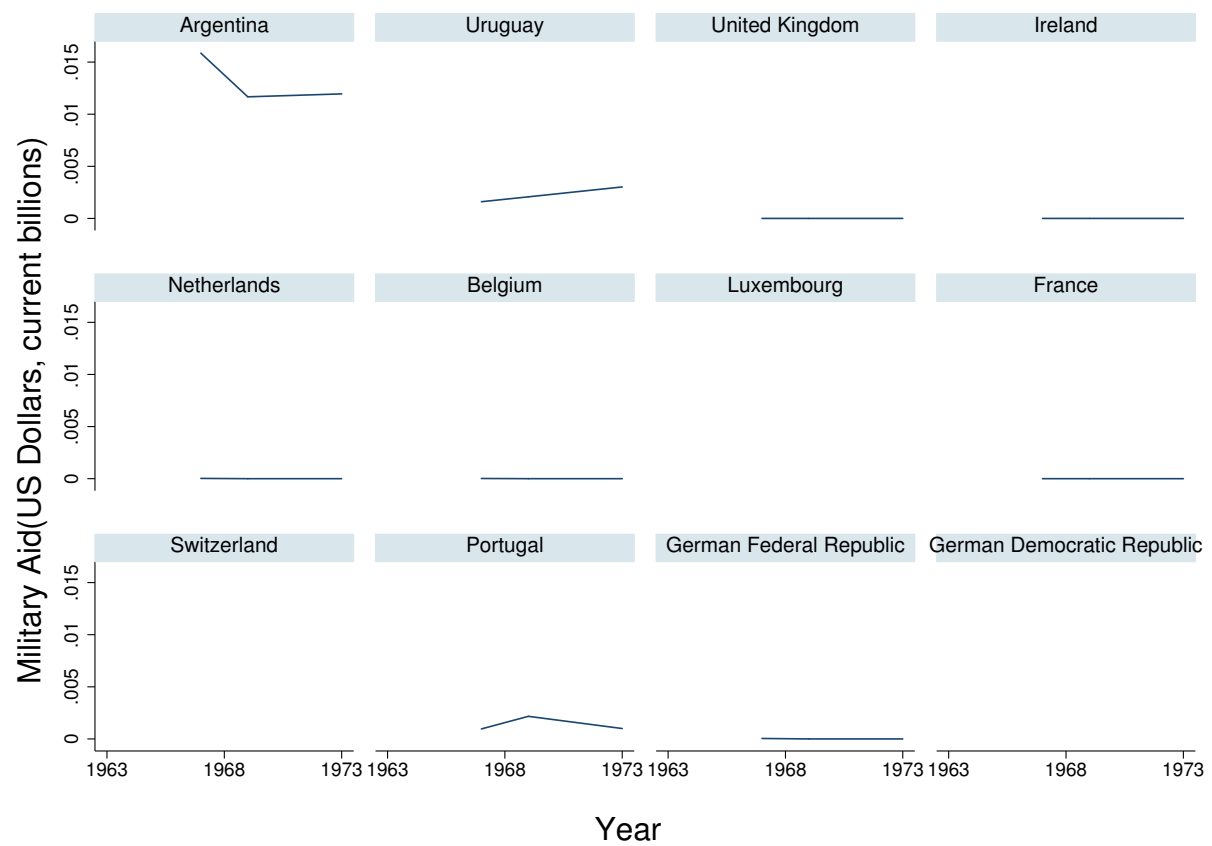


Figure B.7

Military Aid to Non-Participant Countries

4 of 10

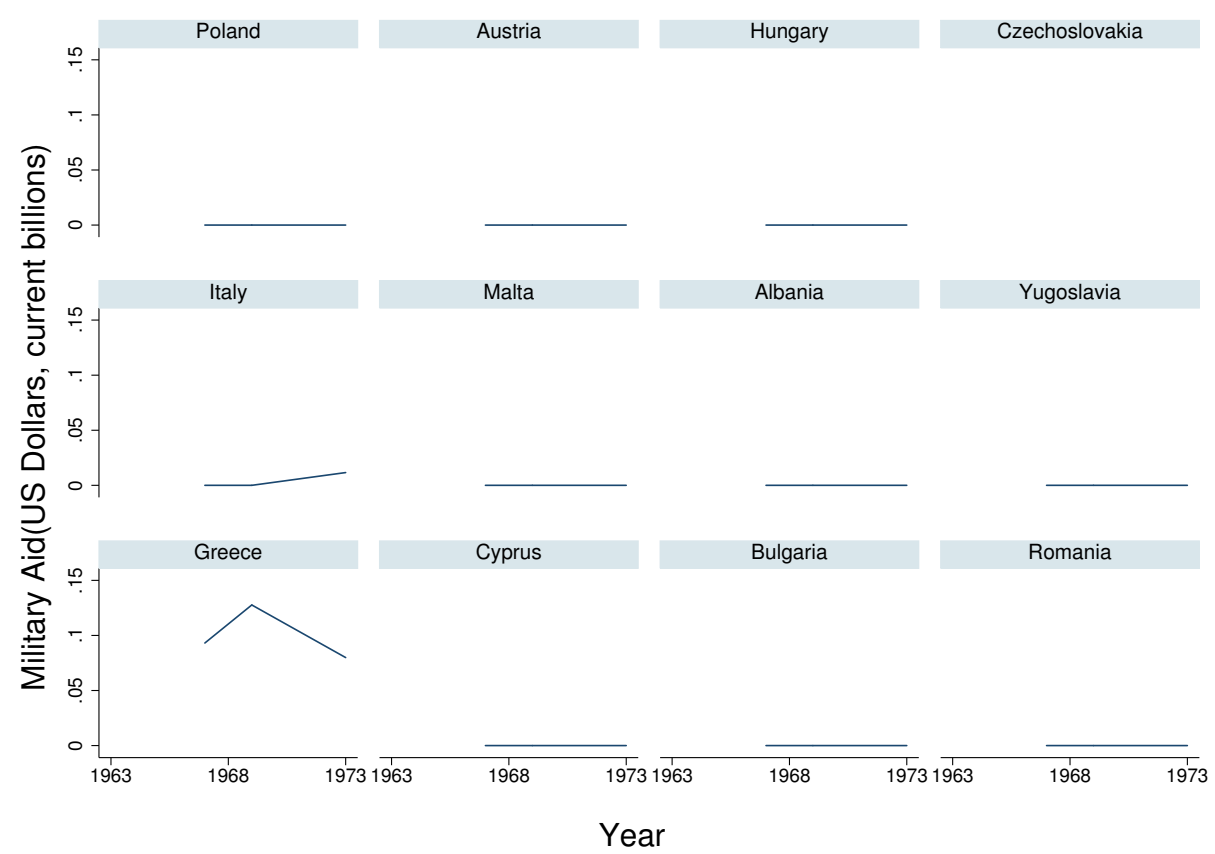

Figure B.8

Military Aid to Non-Participant Countries

5 of 10

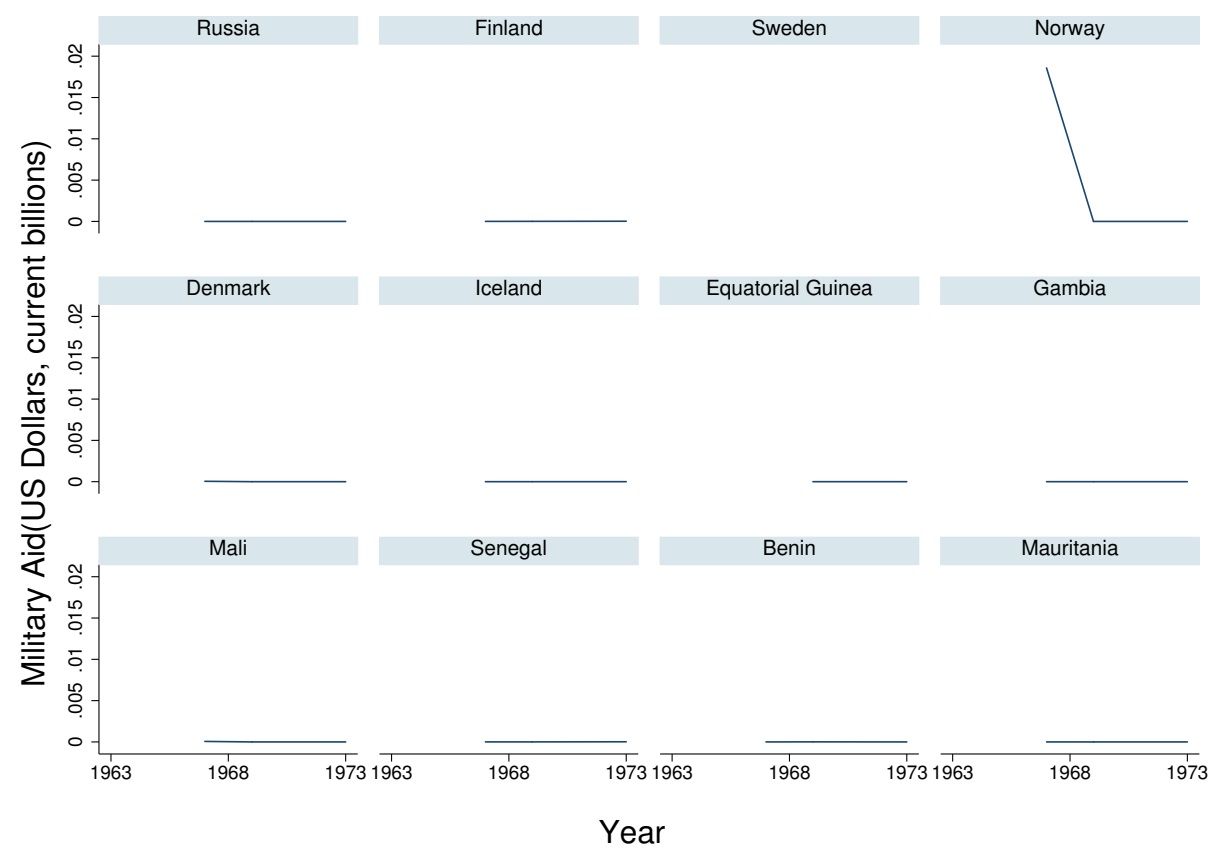


Figure B.9

Military Aid to Non-Participant Countries

6 of 10

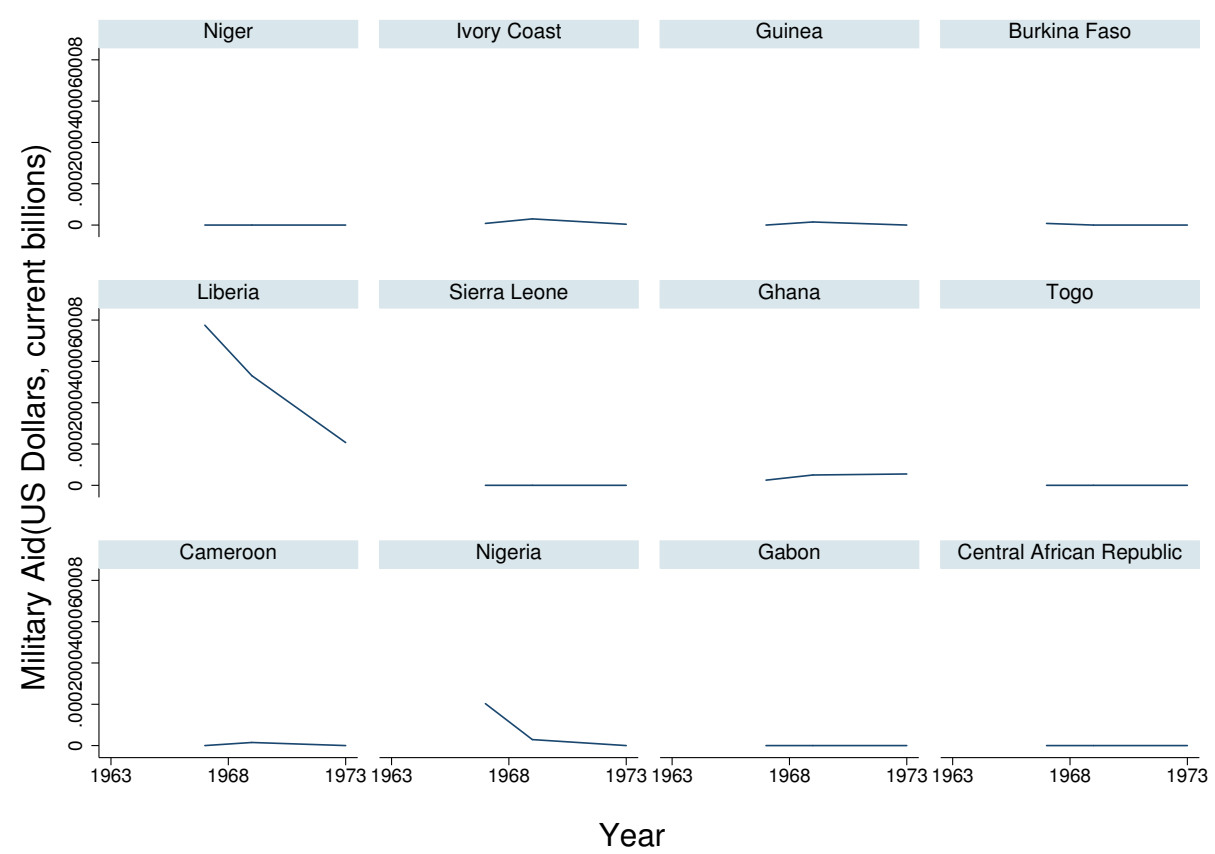

Figure B.10

Military Aid to Non-Participant Countries

7 of 10

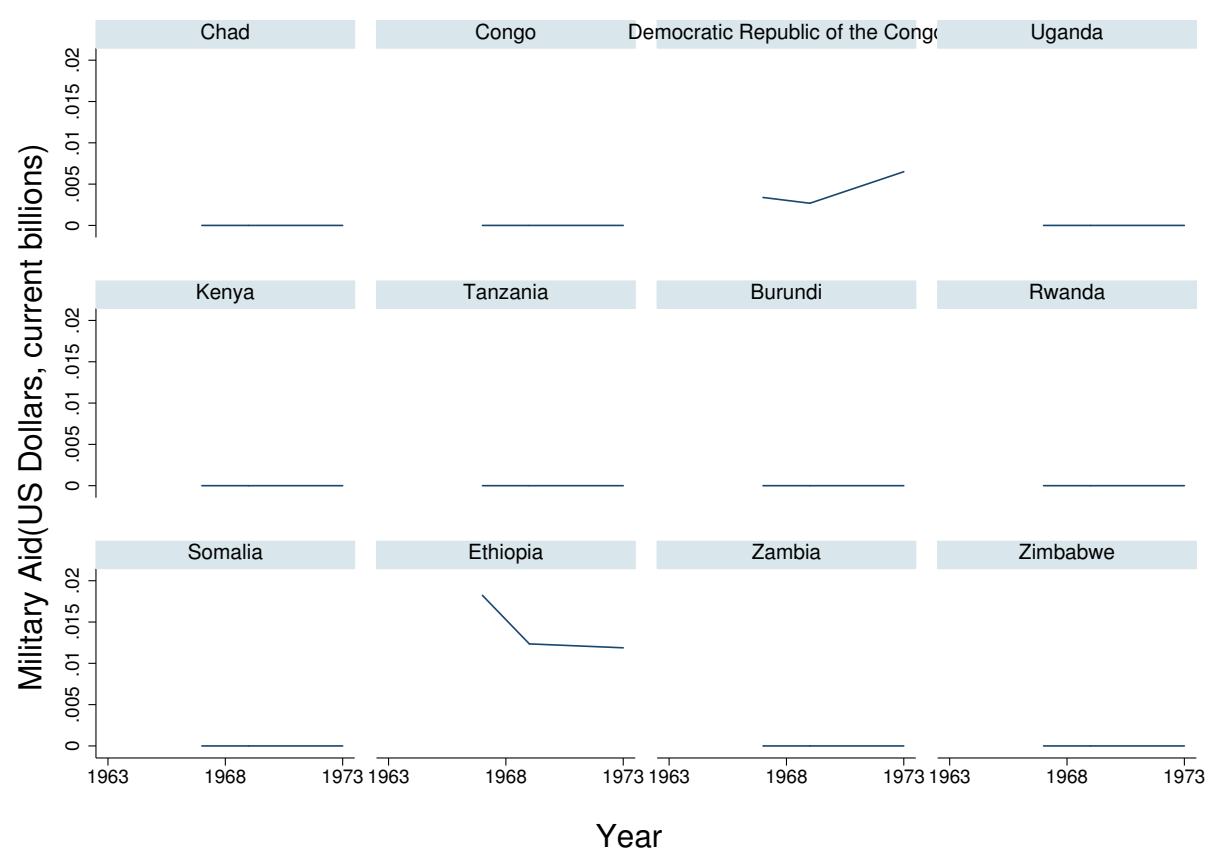


Figure B.11

Military Aid to Non-Participant Countries

8 of 10

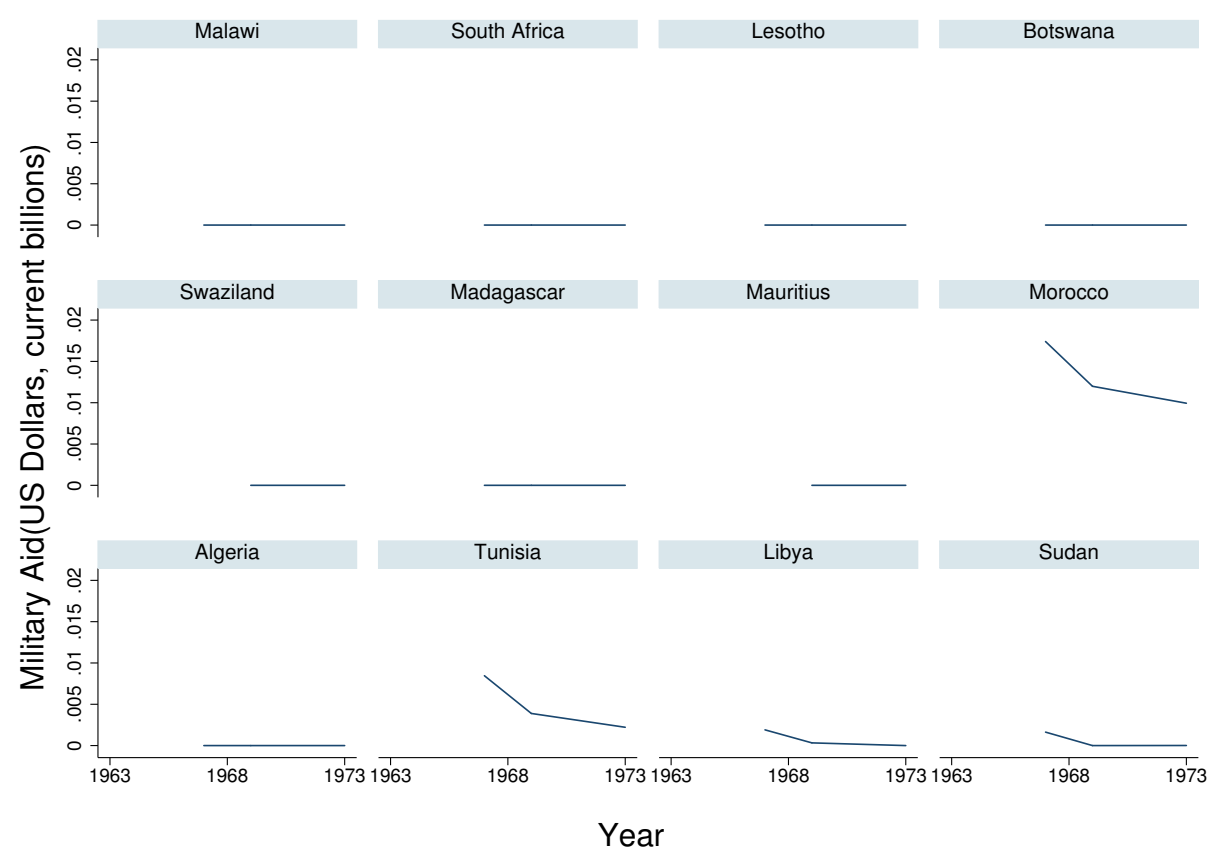

Figure B.12

Military Aid to Non-Participant Countries

9 of 10

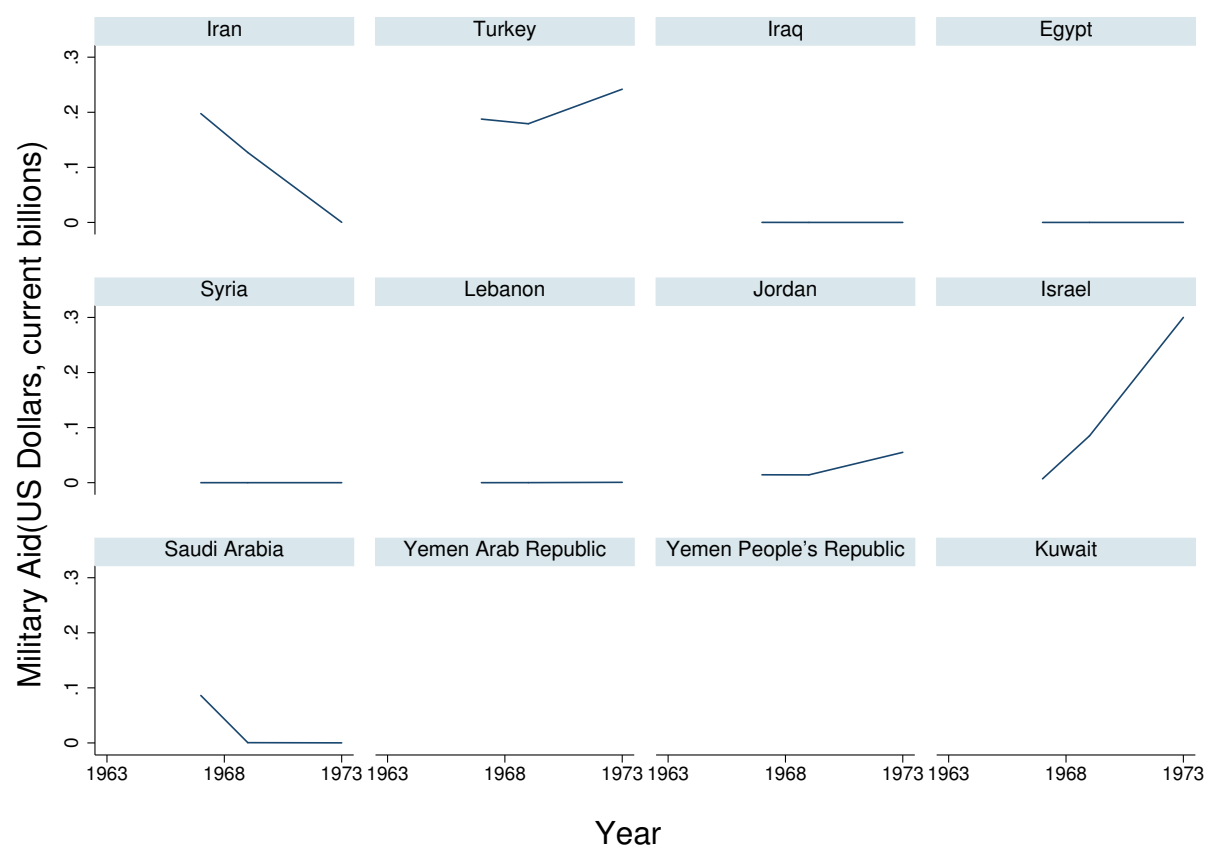


Figure B.13

Military Aid to Non-Participant Countries

10 of 10

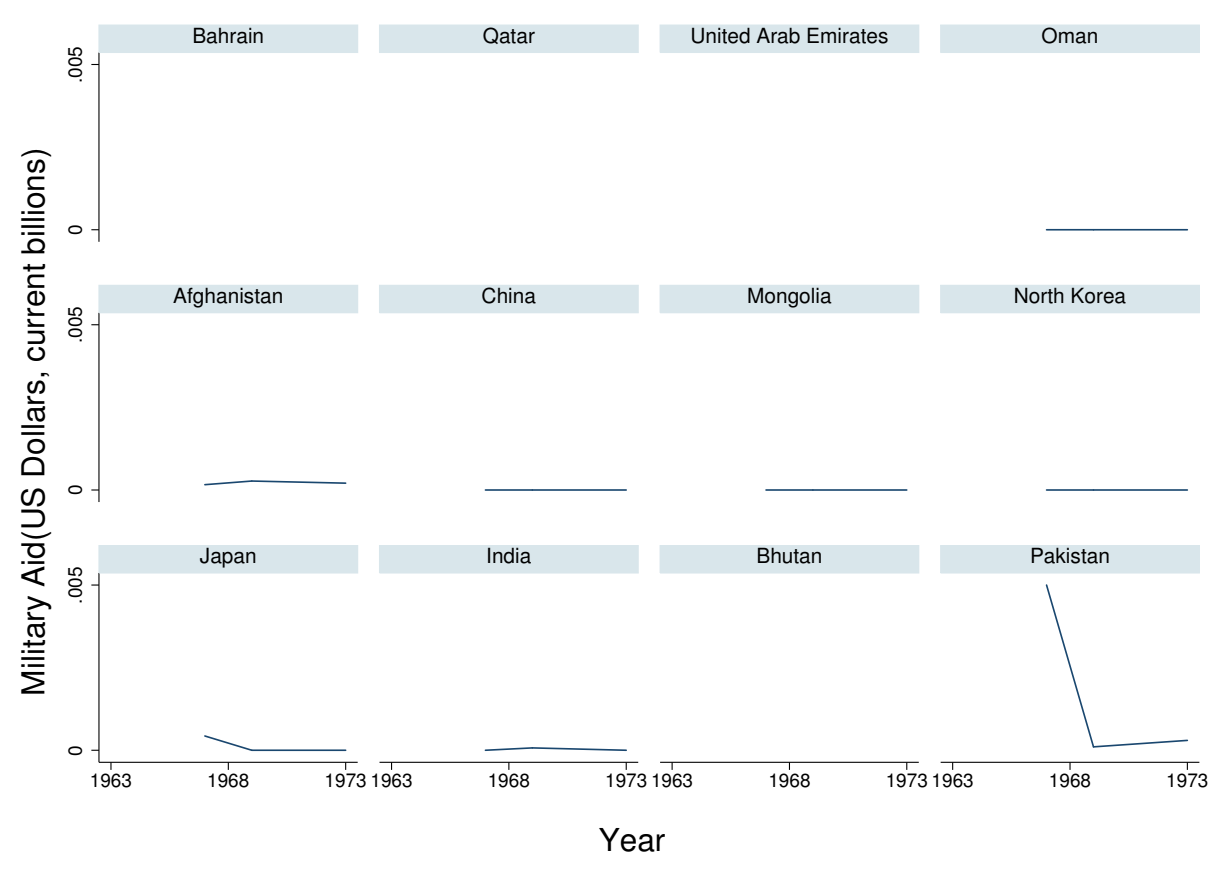




\section{Appendix C}

\section{Full Translated Text of President Park's Speeches}

The speeches provided here have been translated by the author from transcripts provided by the Republic of Korean Presidential Archives website. Refer to their website for the full transcripts in the original language..$^{1}$ 


\section{C.1 Statement to the Nation: January 26, 1965}

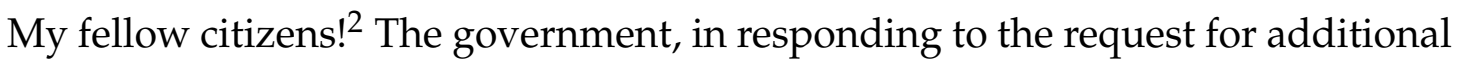
support from the Republic of Vietnam, and following the procedures set forth by our constitution, has gained the consent of our national assembly and is dispatching 2,000 troops. The non-combat forces include forces for self security, military engineers, and transportation units. They will be carrying out the missions given to them at the rear of the lines.

The Republic of Vietnam is currently facing wicked guerrilla attacks from the North Vietnamese who are considered to be supported by Communist China. They are having difficulty in their struggle against communism.

The communist provocation against Vietnam is not limited to the security of Vietnam itself. It is directly linked to the security and peace of Asia, and several allied nations of the free world including the US, are continuously increasing military and economic support for that nation.

It is hardly necessary to say that if free Vietnam communizes, two fearful events can be predicted.

The first is that there is no doubt that confusion and problems will arise in the front against communism held by the free world. The second is that having found a way into Southeast Asia through Vietnam, communist forces will come out with open and radical provocations towards free countries in the entire pacific region including the Korean peninsula.

At this point, we have come to a point where we face a decision: do we sit and wait, or do we stand up beforehand and block this from happening? Facing a danger that could enflame Asia, helping put out the current "embers" in Vietnam is the best way for our security and also our obligation.

\footnotetext{
${ }^{2}$ http://www.pa.go.kr/research/contents/speech/index.jsp accessed March 21, 2016
} 
Accordingly, the Korean government has decided to provide all the necessary support to the Republic of Vietnam, within the limits of not hindering the ability to directly defend our own territory.

First, the decision is based on the moral responsibility we have towards collective security and its protection of Asia's peace and freedom.

Second, the decision is according to the conviction that the communist invasion in Vietnam is directly linked to the security of Korea, and hence, our support for Vietnam is an indirect way of defending our own country.

Third, the decision follows the strong sense of justice and firm resolution we as Koreans have. In the past, we ourselves have overcome communist aggression through the support of 16 free world countries, and we can not let an ally become victim of the same.

Trying at all costs to save a friend drowning in water is the high spirit of our people, a people who love righteousness.

My fellow citizens!

Participating in the fight to defend freedom in Vietnam is at a smaller scale, a way of defending our own freedom, bolstering our security, and strengthening the struggle against communism. At a larger scale, it is an honorable deed that will strengthen the overall global front against communism, serve freedom, and contribute to world peace.

We remember the solemn fact that we defeated the communist invasion on this land with the blood of the young people of our free world allies. And in doing so, we must first stop such invasions in the region by helping those that are in the midst of a hard battle against communism before we ask which country that is, or what people they are.

I believe that our country has come to a point where we must step up from our previous passive position where we received the concerns and assistance of 
others, and now accept responsibility for important international matters. This forward looking posture does entail some sacrifices and obligations.

However, we can not neglect our responsibilities due to such obligations and sacrifices. It is a truth that we have benefitted greatly from other allies in the free world until now. Now, we have the moral responsibility to share some of those benefits with others in situations more dire than us.

We are showing the world that the Republic of Korea is faithfully doing their responsible share.

We want to reconfirm the precious truth that all aggressions must be firmly stopped by supporting free Vietnam as much as we can for the common good.

Through such actions, I am confidant that we will bind to defend freedom and peace, and participate in the ranks of free allies, as we contribute towards world peace and the maintenance of security.

Finally, for our troops embarking on this important mission, I wish you good luck and good fortunes in battle.

\section{C.2 Send Off Speech: October 12, 1965}

My fellow citizens and troops of the Maengho(Tiger) Unit, ${ }^{3}$

Under this high and clear autumn sky, today you embody the honor of our country and glory of our troops as you embark on your journey to the front lines of Vietnam, and as those of us say farewell, are filled with complicated emotions.

Your gallant attitude and ranks remind us that our military is worthy of boasting in the free world, and as we say farewell, our eyes water with pride and faith in you all.

3 http://www.pa.go.kr/research/contents/speech/index. jsp?spMode=view\&catid=c_ pa02062\&artid=1305601, accessed March 21, 1965 
At this solemn ceremony, I want you soldiers to engrave in you hearts our nation's wishes of good luck and fortunes to you and the sincere good wishes from your parents and siblings. I do not doubt your resolute determination and resolve.

Since deciding that defending free Vietnam from the aggressions of communism is our policy, some of our troops have already deployed there and have made significant contributions.

The citizens of free Vietnam and several free allies passionately compliment our mobile hospital and Bidoolgi(pigeon) unit there. They are doing their best to do their mission. The advance party for our combat troops have arrived and await your arrival.

Our ally, the US, is also continuously sending large numbers of troops and they are making significant military gains everyday.

The citizens of free Vietnam, who for the past 20 years have had a lack of confidence due to communist aggressions, are now finally starting to regain courage.

A flash of hope is finally shining in free Vietnam. Their citizens are finally starting to have hope, courage, and confidence. The pessimists that said free Vietnam should be abandoned are now finally starting to think differently.

On the other hand, communist Vietnamese are seeing great damage and losses done with the counter-attack of US forces in Vietnam, and their confidence is falling. The communist Ho-Chi-Min regime's capability to support its troops is dropping drastically due to daily bombings by the US air force.

I have no doubt that communist China, who have been greatly supporting them from behind, are starting to become disconcerted.

Our theory that we must fight force with force in our struggle against communism is proving to be correct. Anyone who witnessed the peace talks at 
Panmunjeom will be able to instantly give you an answer to whether or not peace can be negotiated with communists. I want to highlight that once again today.

If we fail to stop the communist invasion in free Vietnam, we will soon lose all of Southeast Asia, and most definitely not be able to ensure the security of our Republic of Korea. That is why the front lines in Vietnam are a direct extension of our own armistice line.

Therein lies the root purpose and justification of our troops fighting in Vietnam.

My fellow troops of Maengho!

In the five thousand year history of our people, we have never once invaded another abroad or deployed our troops.

However, this time we are going in order to assist a free world ally in trouble caused by the aggressions of communist forces. This a first in our history.

This righteous behavior will shine in our history for a long time. The glory of those actions is yours, and your glory is that of your country's.

I want the soldiers of your unit to have the same pride as those ancient greeks that said "when asked generations later who your ancestors are, tell them your ancestors are the soldiers that fought in Troy."

My fellow troops!

Our country is now at a transitioning point in history. We are entering a new era where we no longer just receive support, but give it in turn to others.

The fact that you embark on this journey as crusaders of freedom will also become a page of history.

Remember that your each and every action is directly linked to the honor of your country.

Do not forget that all of your country, and the world, is watching carefully. 
As descendants of the Hwarang, show off to the world your spirit as son's of Korea, and I ask that you make the honor of your country and its military shine ever more brightly.

Victory will always be on the side that is righteous. In the not too distant future, peace will come to free Vietnam, and we here will await the day that all of you return triumphantly having accomplished your mission.

We here left in the homeland promise to support your victory by giving our everything towards modernizing the country.

Lastly, I hope God is with all of you troops under General Chae Myung Shin, and also your families. I hope for long standing good fortunes for all of you.

Also, I take the opportunity to express my sympathies for former major Kang Jae $\mathrm{Gu}$, who died during training the fourth of this month. 


\section{Data}

Correlates of War Project. [Dataset] Correlates of War Project Dyadic Trade Data Version 3.0. URL: http://www. correlatesofwar.org/data-sets/bilateraltrade.

— [Dataset] Correlates of War Project Formal Alliances version 4.1. 2013. URL: http: //www.correlatesof war.org/data-sets/formal-alliances

- [Dataset] Correlates of War Project Inter-State War Data Version 4.0. URL: http: //www. correlatesof war. org/data-sets/COW-war.

- [Dataset] Correlates of War Project National Material Capabilities version 4.0. URL: http://www . correlatesof war . org/data-sets/national-materialcapabilities.

Kane, Tim. [Dataset] Global US Troops Deployments 1950-2003. Heritage Foundation. URL: http://www. heritage.org/research/reports/2004/10/globalus-troop-deployment-1950-2003?ac=1.

Ministry of Patriots and Veterans Affairs. [Dataset] Korean War Statistics: Size of Participation. URL: http://english.mpva.go.kr

Polity IV Project. [Dataset] Polity IV Annual Time Series, 1800-2013 version 2013. URL: http://www.systemicpeace.org/polityproject.html.

Sarkees, Meredith Reid. [Codebook] The COW Typology of War: Defining and Categorizing Wars (Version 4 of the Data). Correlates of War Project. URL: http: 
/ / cow . la . psu . edu / COW2\% 20Data / WarData_NEW / COW\% 20Website \% 20 $\% 20$ Typology $\% 20 \circ \%$ 20war.pdf.

USAID. [Dataset] USAID Foreign Assistance Data, 1946-2012. URL: https://eads usaid.gov/gbk/data/prepared.cfm.

Weidmann, Nils B., Doreen Kuse, and Kristian Skrede Gleditsch. “The Geography of the International System: The CShapes Dataset". In: International Interactions 36.1 (2010), pp. 86-106. DOI: 10.1080/03050620903554614. 


\section{Primary Sources}

Chi, Madeline and Louis J. Smith, eds. Japan; Korea. Vol. XVIII. Foreign Relations of the United States, 1958-1960. Washington: United States Government Printing Office, 1994.

Dale, Catherine. Operation Iraqi Freedom: Strategies, Approaches, Results, and Issues for Congress. CRS Report for Congress RL34387. Congressional Research Service, 2008.

Department of State. “American Foreign Policy 1950-1955". In: Basic Documents Volume I. General Foreign Policy Series 117 Publication 6446. US Government Printing Office, 1957.

DoD News. Obama, Hagel Mark End of Operation Enduring Freedom. DoD Website. 2014. URL: http://www . defense. gov/news/newsarticle . aspx? id= 123887 (lastchecked:15May2015).

Englehardt, Joseph P. Desert Shield and Desert Storm: A Chronology and Troop List for the 1990-1991 Persian Gulf Crisis. SSI Special Report. Strategic Studies Institute, U.S. Army War College, 1991.

Gatz, Karen L., ed. Part 1, Korea. Vol. XXIX. Foreign Relations of the United States, 1964-1968. Washington: United States Government Printing Office, 2000.

Gerleman, David J., Jennifer E. Stevens, and Steven A. Hildreth. Operation Enduring Freedom: Foreign Pledges of Military and Intelligence Support. CRS Report for 
Congress RL31152. Congressional Research Service, The Library of Congress, 2001 .

Goodwina, Ralph R., N. Stephen Kane, and Harriet D. Schwar, eds. The United Nations; The Western Hemisphere. Vol. II. Foreign Relations of the United States, 1951. Washington: Government Printing Office, 1979.

Graham, Bradley and William Drozdiak. "Allied Action Fails to Stop Serb Brutality". Washington Post. 1999. URL: http : / / www . washingtonpost . com/wp-srv/ inatl/longterm/balkans/stories/military033199.htm

Hernandez, Lyla M. et al. Gulf War Veterans: Measuring Health. Ed. by Committee on Measuring Health of Gulf War Veterans. Washington D.C.: National Academy Press, 1999.

Hickerson, John D. "Memorandum by the Assistant Secretrary of State for United Nations Affairs to the United States Representative at the United Nations". In: Foreign Relations of the United States, 1952-1954 Volume XV, Part 1, Korea, Document 389. US Department of State (Office of the Historian). URL: https: //history.state.gov/historicaldocuments/frus1952-54v15p1/d389.

Johnson, Lyndon B. "Public Papers of the Presidents of the United States (Containing the Public Speeches, and Statements of the President)". In: Lyndon B. Johnson 1965(in two books) Book I-January 1 to May 31, 1965. Vol. I. Washington: United States Government Printing Office, 1966.

— "Public Papers of the Presidents of the United States (Containing the Public Speeches, and Statements of the President)". In: Lyndon B. Johnson 1965(in two books) Book II-June 1 to December 31, 1965. Vol. II. United States Government Printing Office, 1966.

Keefer, Edward C., David W. Mabon, and Harriet D. Schwar, eds. Northeast Asia. Vol. XXII. Foreign Relations of the United States, 1961-1963. Washington: United States Government Printing Office, 1996. 
Madden, Richard L. "Ford says Indochina War is finished for America". New York Times. 1975. URL: http: //www . nytimes . com/library/world/asia/ 042475vietnam-ford-rm.html.

Niksch, Larry A. and Robert G. Sutter. Japan's Response to the Persian Gulf crisis: Implications for U.S.-Japan relations. CRS Report for Congress. Library of Congress, 1991.

Resolution 1386 (2001). S/RES/1386(2001). United Nations Security Council. 2001. Resolution of 25 June 1950. United Nations Security Council. 1950. URL: http: //www.un.org/en/sc/documents/resolutions/1950.shtml.

Resolution of 27 June 1950. United Nations Security Council. 1950. URL: http: //www.un.org/en/sc/documents/resolutions/1950.shtml.

Resolution of 7 July 1950. United Nations Security Council. 1950. URL: http: //www.un.org/en/sc/documents/resolutions/1950.shtml.

Status of UN Offers of Assistance for Korea. Office of Foreign Military Affairs. Washington 25, D.C.: Office of the Secretary of Defense, 1950. URL: http:// WwW . trumanlibrary .org/whistlestop/study_collections/korea/large/ documents/pdfs/ki-18-7.pdf

The Conferences at Cairo and Tehran: The Cairo Declaration. History and Public Policy Program Digital Archive. Washington DC: United States Government Printing Office, 1943. URL: http : / / digitalarchive.wilsoncenter .org/ document/122101

Torreon, Barbara Salazar. U.S. Periods of War and Dates of Recent Conflicts. CRS Report for Congress RS21405. Congressional Research Service, 2015.

US Department of Defense. Allied Contributions to the Common Defense (Responsibility Sharing Report). DoD Website. 2002. URL: http://www.defense.gov/ pubs/allied\%5Fcontrib2002/index.html(lastchecked:20May, 2015). 
USCENTAF. Operation IRAQI FREEDOM - By the Numbers. Unclassified Report. 9AF Shaw AFB, SC: Assessment and Analysis Division, 2003. URL: http://wWw . afhso .af .mil/shared/media/document/AFD-130613-025 pdf (lastchecked:20May2015).

USCENTCOM. United States Central Command: Coalition Countries. United States Central Command Webpage. URL: http://www . centcom . mil/en/about centcom-en/coalition-countries-en 


\section{Secondary Sources}

BBC World Service. Gulf Crisis Chronology. Essex, UK: Longman Group UK Limited, Westgate House, 1991.

Burns, E. Bradford. A History of Brazil. Second. New York: Columbia University Press, 1980.

Carney, Stephen A. Allied Participation in Operation Iraqi Freedom. CMH pub 59-3-1. Washington DC: United States Army Center of Military History, 2011.

Cummings, Bruce. The Korean War: A History. New York: Modern Library, 2010. Edwards, Paul M. Korean War Almanac. 1st ed. Almanacs of American Wars. New York: Facts on File, Inc., 2006.

- United Nations participants in the Korean War: the contributions of 45 member countries. North Carolina: McFarland and Company, Inc., 2013.

Lawrence, Mark Atwood. The Vietnam War: A Concise International History. New York: Oxford University Press, 2008.

Lulat, Y.G-M. United States Relations with South Africa: A Critical Overview from the Colonial Period to the Present. New York: Peter Lang Publishing Inc, 2008.

Miller, Ronnie. Following the Americans to the Persian Gulf: Canada, Australia, and the Development of the New World Order. Cranbury, New Jersey: Associated University Presses, Inc., 1994. 
Moïse, Edwin E. Historical Dictionary of the Vietnam War. Historical Dictionaries of War, Revolution, and Civil Unrest 17. Lanham, Maryland, London: The Scarecrow Press, Inc., 2001.

NATO Public Diplomacy Division. NATO Handbook. Vol. HB-ENG-0406. Brussels, Belgium: NATO, 2006.

Neumann, Brian F., Lisa Mundey, and Jon Mikolashek. The United States Army in Afghanistan: Operation Enduring Freedom, March 2002-April 2005. CMH pub 70-122-1. Washington DC: United States Army Center of Military History, 2013. URL: http : / / www . history . army . mil / html / books / 070 / 70 - 122 1/index.html.

Peters, John E. et al. European Contributions to Operation Allied Force: Implications for Transatlantic Cooperation. Santa Monica, CA: RAND, 2001.

Sarantakes, Nicholas Evan. "In the Service of Pharaoh? The United States and the Deployment of Korean Troops in Vietnam, 1965-1968". In: Pacific Historical Review 68.3 (1999), pp. 425-449.

Schaller, Michael. "The Korean War in World History”. In: ed. by William Stueck. Lexington: The University Press of Kentucky, 2004. Chap. 5. The Korean War. The Economic Strategic Impact on Japan 1950-53, pp. 145-176.

Smallman, Shawn C. Fear and Memory in the Brazilian Army and Society, 1889-1954. Chapel Hill: The University of Carolina Press, 2002.

Stewart, Richard. War in the Persian Gulf: Operations Desert Shield and Desert Storm, August 1990-March 1991. CMH pub 70-117-1. Washington DC: United States Army Center of Military History, 2010.

Summers, Harry G. Vietnam War Almanac. New York: Facts on File Publications, 1985. 


\section{Articles and Books}

Ashraf, Ali. "The Politics of Coalition Burden-Sharing: The Case of the War in Afghanistan". PhD thesis. University of Pittsburgh Graduate School of Public and International Affairs, 2011.

Baldwin, David A. Economic Statecraft. Princeton, New Jersey: Princeton University Press, 1985.

Baltrusaitis, Daniel F. "Friends Indeed? Coalition Burden Sharing and the War in Iraq". PhD thesis. Washington D.C.: Georgetown University, 2008.

Barnett, Michael N. and Jack S. Levy. “Domestic sources of alliances and alignments: the case of Egypt, 1962-73". In: International Organization 45.3 (1991), pp. 369-395.

Baum, Matthew A. “The Iraq Coalition of the Willing and (Politically) Able: Party Systems, the Press, and Public Influence on Foreign Policy". In: American Journal of Political Science (2012), pp. 1-17. DOI: 10.1111/j.1540-5907. 2012 $00627 . x$

Bennett, Andrew, Joseph Lepgold, and Danny Unger. "Burden-sharing in the Persian Gulf War". In: International Organization 48.01 (1994), pp. 39-75. DOI: $10.1017 / \mathrm{S} 0020818300000813$

Bensahel, Nora. "A Coalition of Coalitions: International Cooperation Against Terrorism". In: Studies in Conflict and Terrorism 29 (2006), pp. 35-49. DOI: $10.1080 / 10576100500351284$ 
Bergsmann, Stefan. "The Concept of Military Alliance". In: Small States and Alliances. Ed. by Erich Reiter and Heinz Gärtner. New York: Physica-Verlag, 2001, pp. 25-37.

Cha, Victor D. “Abandonment, Entrapment, and Neoclassical Realism in Asia: The United States, Japan, and Korea". In: International Studies Quarterly 44 (2000), pp. 261-291.

Choi, Dong-Ju(최동주). "한국의 베트남 전쟁 참전 동기에 관한 재고찰(The Background to Korea's Involvement in the Second Indochina War)". In: 한국정치 학회보(Korean Political Science Review) 30.2 (1996), pp. 267-287.

Copeland, Dale C. Economic Interdependence and War. Princeton, New Jersey: Princeton University Press, 2015.

Corbetta, Renato and William J. Dixon. "Multilateralism, Major Powers, and Militarized Disputes". In: Political Research Quarterly 57.1 (2004), pp. 5-14.

Crescenzi, Mark J. C. "Economic Exit, Interdependence, and Conflict”. In: The Journal of Politics 65.3 (2003), pp. 809-832.

Davis, Christina L. Food Fights Over Free Trade: How International Institutions Promote Agricultural Trade Liberalization. Princeton, New Jersey: Princeton University Press, 2003.

deMello Jr., Luiz R. “Foreign Direct Investment in Developing Countries and Growth: A Selective Survey". In: The Journal of Development Studies 34.1 (1997), pp. 1-34.

Eichengreen, Barry and David Leblang. "Democracy and Globalization". In: Economics and Politics 20.3 (2008), pp. 289-333. DOI: 10.1111/j .1468-0343. 2007.00329.x.

Gärtner, Heinz. "Small States and Alliances". In: Small States and Alliances. Ed. by Erich Reiter and Heinz Gärtner. New York: Physica-Verlag, 2001, pp. 1-9. 
Gartzke, Eric and Kristian Skrede Gleditsch. "Why Democracies May Actually Be Less Reliable Allies". In: American Journal of Political Science 48.4 (2004), pp. 775-795.

Gibler, Douglas M. and Scott Wolford. "Alliances, Then Democracy: An Examination of the Relationship between Regime Type and Alliance Formation". In: Journal of Conflict Resolution 50.1 (2006), pp. 129-153. DOI: 10.1177/ 0022002705281360

Globerman, Steven. "Foreign direct investment and 'spillover' efficiency benefits in Canadian manufacturing industries". In: Canadian Journal of Economics XII.1 (1979), pp. 42-56.

Hirschman, Albert O. National Power and the Structure of Foreign Trade. Berkeley and Los Angeles: University of California Press, 1945.

Hoffmann, Stanley. "An American Social Science: International Relations". In: Daedalus 106.3 (1977), pp. 41-60.

Iamsiraroj, Sasi. "The foreign direct investment-economic growth nexus". In: International Review of Economics and Finance 42 (2016), pp. 116-133. URL: http://dx.doi.org/10.1016/j.iref.2015.10.044.

Joyce, Kyle A., Faten Ghosn, and R. Bayer. "When and Whom to Join: The Expansion of Ongoing Violent Interstate Conflicts". In: British Journal of Political Science 44.01 (2014), pp. 205-238. DOI:10.1017/S0007123412000506.

Keohane, Robert O. and Joseph S. Nye. Power and Interdependence. Boston: Little, Brown and Company, 1977.

Krause, Volker and J. David Singer. "Minor Powers, Alliances, and Armed Conflict: Some Preliminary Patterns". In: Small States and Alliances. Ed. by Erich Reiter and Heinz Gärtner. New York: Physica-Verlag, 2001, pp. 15-23. 
Lai, Brian and Dan Reiter. "Democracy, Political Similarity, and International Alliances, 1816-1992". In: Journal of Conflict Resolution 44.2 (2000), pp. 203-227. DOI: $10.1177 / 0022002700044002003$,

Lake, David A. Hierarchy in International Relations. Ithaca, New York: Cornell University Press, 2009.

Leeds, Brett Ashley. “Do Alliances Deter Aggression? The Influence of Military Alliances on the Initiation of Militarized Interstate Disputes". In: American Journal of Political Science 47.3 (2003), pp. 427-439.

Leeds, Brett Ashley et al. "Alliance Treaty Obligations and Provisions, 1815-1944". In: International Interactions 28.3 (2002), pp. 237-60.

Mearsheimer, John J. The Tragedy of Great Power Politics. New York: W.W. Norton and Company Inc, 2001.

Mercer, Jonathan. Reputation and International Politics. Ithaca: Cornell University Press, 1996.

Miller, Gregory D. The Shadow of the Past: reputation and military alliances before the First World War. Cornell Studies in Security Affairs. Ithaca, New York: Cornell University Press, 2012.

Moon, Chung-In and Sunghack Lim. “Understanding Korean Politics: An Introduction". In: ed. by Soong Hoom Kil and Chung-In Moon. SUNY series in Korean studies. Albany: State University of New York Press, 2001. Chap. 8. The Politics of Economic Rise and Decline in South Korea, pp. 201-30.

Most, Benjamin A. and Harvey Starr. "Diffusion, Reinforcement, Geopolitics, and the Spread of War". In: American Journal of Political Science Review 74 (1980), pp. 932-946.

- Inquiry, Logic, and International Politics. Columbia: University of South Carolina Press, 1989. 
Most, Benjamin A., Harvey Starr, and Randolph Siverson. "Handbook of War Studies". In: ed. by Manus Midlarsky. Allen and Unwin, 1989. Chap. The Logic and Study of the Diffusion of International Conflict.

Newnham, Randall. "'Coalition of the Bribed and Bullied?" U.S. Economic Linkage and the Iraq War Coalition". In: International Studies Perspectives 9 (2008), pp. 183-200.

Park, Keunho. "The Vietnam War and the 'Miracle of East Asia'". In: Inter-Asia Cultural Studies 4.3 (2003), pp. 372-399.

Reiter, Dan and Alan C. Stam. Democracies at War. Princeton, New Jersey: Princeton University Press, 2002.

Siverson, Randolph M. and Joel King. "Attributes of National Alliance Membership and War Participation". In: American Journal of Political Science 24.1 (1980), pp. 1-15.

Siverson, Randolph M. and Harvey Starr. "Willingness, and the Diffusion of War". In: The American Political Science Review 84.1 (1990), pp. 47-67.

Smith, Alastair. "Alliance Formation and War". In: International Studies Quarterly 39.4 (1995), pp. 405-425.

Snyder, Glenn H. Alliance Politics. Cornell Studies in Security Affairs. Ithaca: Cornell University Press, 1997.

_ "The Security Dilemma in Alliance Politics". In: World Politics 36.4 (1984), pp. 461-495.

Tago, Atsushi. "Determinants of Multilateralism in US use of Force: State of Economy, Election Cycle, and Divided Government". In: Journal of Peace Research 42.5 (2005), pp. 585-604. DOI: 10.1177/0022343305056235.

- "Is there an aid-for-participation deal?: US economic and military aid policy to coalition forces (non)participants". In: International Relations of the AsiaPacific 8 (2008), pp. 379-398. DOI: 10.1093/irap/lcn010. 
Tago, Atsushi. "Why do states join US-led military coalitions?: The compulsion of the coalition's missions and legitimacy". In: International Relations of the Asia-Pacific 7 (2007), pp. 179-202. DOI: 10.1093/irap/lc1001.

Walt, Stephen M. Is IR still 'an American social science?' 2011. URL: http :// foreignpolicy . com/2011/06/06/is - ir - still - an - american - social science/, accessedMarch15, 2016.

- The Origins of Alliances. Cornell Studies in Security Affairs. Ithaca: Cornell University Press, 1987.

Werner, Suzanne and Douglas Lemke. “Opposites Do Not Attract: The Impact of Domestic Institutions, Power, and Prior Commitments on Alignment Choices". In: International Studies Quarterly 41 (1997), pp. 529-46.

Womack, Brantly. Asymmetry and International Relationships. New York: Cambridge University Press, 2016.

- China and Vietnam: the politics of asymmetry. New York: Cambridge University Press, 2006. 


\section{Manuals, Reports, and other}

\section{Publications}

Larsen, Stanley Robert and James Lawton Collins. Vietnam Studies: Allied Participation in Vietnam. CMH pub 90-5-1. Washington DC: Department of the Army, 1974. URL: http://www.history .army.mil/books/vietnam/allied/ index.htm\#contents (lastchecked:20May, 2015).

Larson, Eric et al. Interoperability of U.S. and NATO Allied Air Forces: Supporting Data and Case Studies. Research Report. RAND, 2003.

US Department of Defense. Kosovo/Operation Allied Force After-Action Report. Report to Congress. Department of Defense, 2000. URL: http: //www . dod mil/pubs/kaar02072000.pdf (lastChecked:20May2015).

US JCS. Department of Defense Dictionary of Military and Associated Terms, Joint Publication 1-02. http:/ / www.dtic.mil/doctrine/dod_dictionary. Washington DC, 2010. 


\section{Additional References}

Allesina, Alberto and David Dollar. "Who Gives Foreign Aid to Whom and Why?" In: Journal of Economic Growth 5 (2000), pp. 33-63. DOI: doi: 10. 1023/A: 1009874203400 .

Anderson, Sarah, Phyllis Bennis, and John Cavanagh. "Coalition of the Willing or Coalition of the Coerced? How the Bush Administration Influences Allies in its War on Iraq". In: Washington, DC: Institute of Policy Studies (2003).

Armstrong, Charles K. “America's Korea, Korea's Vietnam". In: Critical Asian Studies 33.4 (2001), pp. 527-539.

Asiedu, Elizabeth. "On the Determinants of Foreign Direct Investment to Developing Countries: Is Africa Different?" In: World Development 30.1 (2002), pp. 107-119.

Barbieri, Katherine and Omar M. G. Keshk. [Codebook] Codebook for the Correlates of War Project's Trade Data Set, Version 3.0. Correlates of War Project. 2012. URL: http://www.correlatesof war.org/data-sets/bilateral-trade.

Bell, John Patrick. Crisis in Costa Rica: The 1948 Revolution. Austin: University of Texas Press, 1971.

Blanchard, Jean-Marc F., Edward D. Mansfield, and Norrin M. Ripsman, eds. Power and the Purse: Economic Statecraft, Interdependence, and National Security. Cass Series on Security Studies. Portland, OR: Frank Cass, 2000. 
Blokker, Niels. "Is the Authorization Authorized? Powers and Practice of the UN Security Council to Authorize the Use of Force by 'Coalitions of the Able and Willing'"'. In: European Journal of International Law 11.3 (2000), pp. 541-568.

Boix, Carles, Michael Miller, and Sebastian Rosato. “A Complete Data Set of Political Regimes, 1800-2007". In: Comparative Political Studies Online (http:/ / cps.sagepub.com/content/early/2013/04/04/0010414012463905) (2012).

Burns, E. Bradford. A Documentary History of Brazil. Ed. by Lewis Hanke. First. Borzoi Books on Latin America. New York: Alfred A. Knopf, Inc., 1966.

Byman, Daniel. "Remaking Alliances for the War on Terrorism". In: The Journal of Strategic Studies 29.5 (2006), pp. 767-811. DOI: 10.1080/01402390600900887. Choi, Yong-Ho(최용호). “한국군 베트남 파병시 미국의 지원과 '용병 주장' 분석(The Critical Analysis of Assertion, ROKA of Participation in the Vietnam War as 'Mercenary Soldiers')". In: 군사(Military History) 48 (2003), pp. 239-277.

Copeland, Dale C. The Origins of Major War. Cornell Studies in Security Affairs. Ithaca, New York: Cornell University Press, 2000.

Correlates of War Project. [Codebook] National Material Capabilities Data Documentation Version 4.0. 2010. URL: http: //www . correlatesofwar . org/datasets/national-material-capabilities

Cummings, Bruce. The Roaring of the Cataract, 1947-1950. The Origins of the Korean War Vol. 2. New Jersey: Princeton University Press, 1990.

Gibler, Douglas M. [Codebook] Release Notes for Version 4: Correlates of War Formal Interstate Alliance Dataset, 1816-2012. Correlates of War Project. 2013. URL: http: //www. correlatesof war.org/data-sets/formal-alliances.

Hirschman, Albert O. A Propensity to Self-Subversion. Massachusetts: Harvard University Press, 1995.

Hong, Wontack. Trade and Growth: A Korean Perspective. Seoul: Kudara International, 1994. 
Lewinsohn, Richard. The Profits of War through the Ages (Les Profits de Guerre à travers Les Siècles). London: George Routledge and Sons LTD, 1936.

Mansfield, Edward D. and Brian M. Pollins, eds. Economic Interdependence and International Conflict: New Perspectives on an Enduring Debate. Michigan Studies in International Political Economy. Ann Arbor: The University of Michigan Press, 2003.

Marshall, Monty G., Ted R. Gurr, and Keith Jaggers. [Codebook] Polity IV Project Political Regime Charactersitics and Transitions, 1800-2013 Dataset Users' Manual. Center for Systemic Peace. 2014. URL: http : / / www . systemicpeace . org/ polityproject.html.

Mello, Patrick A. Democratic Participation in Armed Conflict. Palgrave Studies in International Relations. New York: Palgrave Macmillan, 2014.

Pierre, Andrew J. Coalitions Building and Maintenance: The Gulf War, Kosovo, Afghanistan, and the War on Terrorism. Washington DC: Gerogetown University Institute for the Study of Diplomacy, 2002.

Pressman, Jeremy. Warring Friends: Alliance Restraint in International Politics. Cornell Studies in Security Affairs. Ithaca, New York: Cornell University Press, 2008. 